\title{
Cyber-pragmatika i evolucijski aspekti diskursnih oznaka
}

Jurčević, Jana

Doctoral thesis / Disertacija

2021

Degree Grantor / Ustanova koja je dodijelila akademski / stručni stupanj: University of Zagreb, Faculty of Humanities and Social Sciences / Sveučilište u Zagrebu, Filozofski fakultet

https://doi.org/10.17234/diss.2021.202410

Permanent link / Trajna poveznica: https://urn.nsk.hr/urn:nbn:hr:131:537585

Rights / Prava: In copyright/Zaštićeno autorskim pravom.

Download date / Datum preuzimanja: 2023-04-26

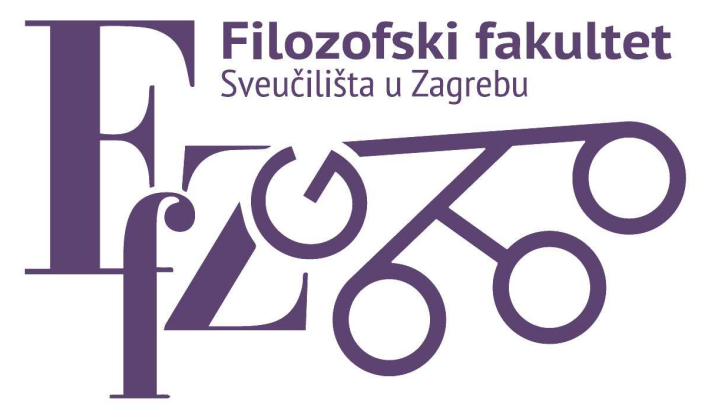

Repository / Repozitorij:

ODRAZ - open repository of the University of Zagreb Faculty of Humanities and Social Sciences
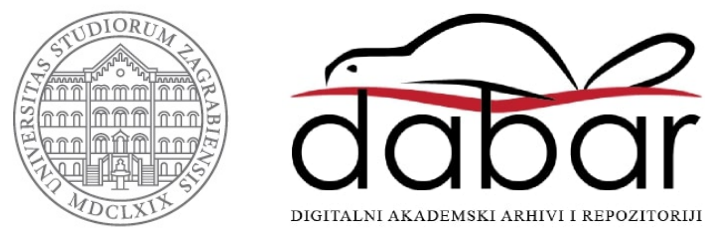
FILOZOFSKI FAKULTET

Jana Jurčević

\section{CYBER-PRAGMATIKA I EVOLUCIJSKI ASPEKTI DISKURSNIH OZNAKA - OD DIJALOGIČNOSTI ŠUTNJE DO IZVORA POŠTAPALICA}

DOKTORSKI RAD

Zagreb, 2021. 
FILOZOFSKI FAKULTET

Jana Jurčević

\title{
CYBER-PRAGMATIKA I EVOLUCIJSKI ASPEKTI DISKURSNIH OZNAKA - OD DIJALOGIČNOSTI ŠUTNJE DO IZVORA POŠTAPALICA
}

DOKTORSKI RAD

\author{
Mentori: \\ izv. prof. dr. sc. Milorad Pupovac \\ red. prof. dr. sc. Mislava Bertoša
}

Zagreb, 2021. 


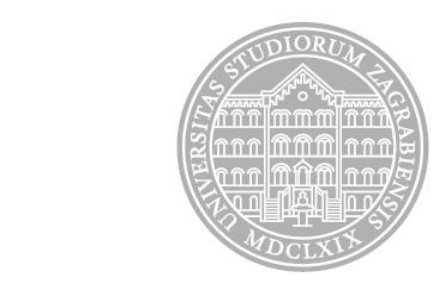

University of Zagreb

FACULTY OF HUMANITIES AND SOCIAL SCIENCES

Jana Jurčević

\title{
CYBER PRAGMATICS AND \\ EVOLUTIONARY ASPECTS OF \\ DISCOURSE MARKERS - FROM \\ DIALOGIC SILENCE TO THE SOURCE OF PROP-WORDS
}

DOCTORAL THESIS

\author{
Supervisors: \\ Associate Professor Milorad Pupovac, PhD \\ Full Professor Mislava Bertoša, PhD
}

Zagreb, 2021. 


\section{Podaci o mentorima:}

Dr. sc. Milorad Pupovac izvanredni je profesor i predstojnik Katedre za primijenjenu lingvistiku Odsjeka za lingvistiku Filozofskog fakulteta Sveučilišta u Zagrebu. Na Filozofskom fakultetu Sveučilišta u Zagrebu studirao je filozofiju i lingvistiku, te 1979. godine diplomirao na objema studijskim grupama. 1982. zapošljava se na Odsjeku za lingvistiku i orijentalne studije, na sociolingvističkom istraživačkom projektu Društveno raslojavanje jezika, koji je sam pripremio i koji je radio pod vodstvom Dubravka Škiljana. Poslijediplomski studij završava 1983. godine na Odsjeku za filozofiju Filozofskog fakulteta Sveučilišta u Ljubljani, gdje brani magistarski rad Lingvistika i ideologija. Doktorsku disertaciju Jezik i djelovanje obranio je 1986. godine. Iste godine izabran je u zvanje docenta, a četiri godine kasnije u zvanje izvanrednog profesora, kada postaje predstojnik Katedre za primijenjenu lingvistiku. U tom razdoblju najveći dio njegova interesa posvećen je sociolingvistici, pragmalingvistici, filozofiji jezika i epistemologiji lingvistike.

1986. s Dubravkom Škiljanom i mlađim kolegama i studentima pokreće lingvistički časopis i biblioteku SOL, te obavlja dužnost glavnog urednika i časopisa i biblioteke SOL. Časopis i biblioteka objavljivani su do početka devedesetih godina prošlog stoljeća.

Tijekom 90-ih njegov se interes proširuje na javnu komunikaciju i analizu diskursa, psiholingvistiku (posebno problem učenja jezika i jezičnih poremećaja) te se produbljuje njegov interes za epistemologiju lingvistike. Početkom dvijetisućitih u područje njegova interesa ulazi problematika semantike razumijevanja i etike govorenja. Na osnovi tih interesa u vrijeme reforme ukupnog studija oblikuje studije primijenjene lingvistike.

U drugoj polovici 90 -ih godina 20. stoljeća i početkom dvijetisućitih bio je predavač na Institutu za humanističke studije u Ljubljani, predajući teme iz sociolingvistike. 1996. stipendist je Centra Woodrow Wilson (Washington, DC) za međunarodne znanstvenike. 1998./1999. godine bio je stipendist Fulbrightova programa na Sveučilištu Cornell (Ithaca, NY).

Od kraja 80-ih godina 20. stoljeća aktivan je u procesu demokratizacije, antiratnim aktivnostima, te domaćim i međunarodnim političkim aktivnostima. Četiri je puta biran za zastupnika u Hrvatskom saboru.

Autor je nekoliko knjiga s područja lingvistike: Lingvistika i ideologija, Jezik i djelovanje, Politička komunikacija. Bio je urednikom je i suurednikom zbornika Jezici i politike te Marksizam i lingvistika. Autor je preko stotine znanstvenih i stručnih radova. Osim 
lingvističkih radova i predavanja, obavljivao je radove i držao predavanja s područja međuetničkih odnosa, manjinskih pitanja i političkih odnosa u regiji jugoistočne Europe.

Dr. sc. Mislava Bertoša redovna je profesorica i predstojnica Katedre za semiologiju Odsjeka za lingvistiku Filozofskog fakuteta Sveučilišta u Zagrebu. Ondje je diplomirala filozofiju i opću lingvistiku i biva zaposlenom 2000. godine na Odsjeku za lingvistiku. 2002. magistrirala je na Sveučilištu u Zadru, a 2007. godine doktorirala je na Filozofskom fakultetu u Zagrebu pod naslovom Semiološki pristup reklamnome diskursu (na korpusu istarskih publikacija iz posljednjih desetljeća austro-ugarske vladavine).

Bavi se temama s područja onomastike, sociosemiotike i semiologije, analize diskursa, odnosa jezika i identiteta te jezika i roda. Sudjelovala je na nekoliko domaćih i međunarodnih znanstvenih projekata te na dvadesetak znanstvenih skupova.

Uz regularnu nastavu na Prediplomskom i Diplomskom studiju lingvistike prof. Bertoša predaje na Poslijediplomskom doktorskom studiju lingvistike na Filozofskom fakultetu Sveučilišta u Zagrebu. Od akademske godine 2013./2014. do 2017./2018. obavljala je i dužnost pročelnice Odsjeka za lingvistiku.

Također, glavna je urednica časopisa Suvremena lingvistika i zamjenica voditeljice doktorskog studija lingvistike. Objavila je tri autorske knjige i niz znanstvenih radova u časopisima s domaćom i međunarodnom recenzijom.

Voditeljica je bilateralnog projekta Odnos slike i teksta u reklamama u tisku s Odsjekom za lingvistiku Sveučilišta u Beču (2015. - 2017.). Kao glavni istraživač u Hrvatskoj od 1. ožujka 2016. sudjeluje u provedbi projekta iz okvira Obzor2020 „ACCOMPLISSH - ACcelerate COcreation by setting up a Multi-actor PLatform for Impact from Social Science and Humanities." 


\section{SAŽETAK}

Od pojave jezikoslovnog interesa za njihov značaj, diskursne oznake predstavljaju problematičnu kategoriju. Različiti su pristupi s vremenom stvorili terminološku zbrku, a zbog činjenice što sama kategorija nije uniformno definirana, stvoreno je okružje u kojem one svoj status iz pragmatične kategorije počinju mijenjati u rezidualnu kategoriju jezika. Tome je doprinjelo i njihovo proučavanje u sklopu vrlo uskih tema i/ili u okviru specifičnih teorija s vlastitom heuristikom. Ne bi li se nadogradila dosadašnja saznanja, ovdje će diskursnim oznakama biti dano prvenstvo.

Što preciznijim određivanjem njihova sinkronijskog statusa u vidu pragmatički utemeljene jezične kategorije i pružanjem dijakronijskog uvida u kategoriju, u kontekstu cyberkomunikacije, odredit će se položaj diskursnih oznaka u jezičnom sustavu, kao i njihova vrijednost za sustav koja se manifestira pri upotrebi. Još preciznije, raspravljat će se o razvojnim aspektima dikursnih oznaka s ciljem njihova razgraničenja od šutnje i kategorije poštapalica. $\mathrm{Na}$ taj će se način dijakronijskim pristupom ovoj pragmatičnoj kategoriji i osvrtanjem na marginalizirane pojavnosti u jeziku (npr. šutnja i poštapalice) nastojati doprinijeti i teoriji jezične evolucije, ali i istaknuti potrebu za formulacijom gramatičkih modela koji bi obuhvaćali i diskursnu razinu jezika.

Konkretna analiza provedena je na privatnom korpusu od 600 razgovora vođenih razmjenom instant poruka (upotrebom aplikacija Hangouts, Facebook messenger, Whatsapp) i primjerima izabranim s Hrvatskog mrežnog korpusa $(h r W a C)$, što je poslužilo kao referentni korpus. Metodološki i teorijski analiza je potpomognuta postavkama konverzacijske analize, pragmatike, analize diskursa, filozofije jezika i funkcionalnim pristupima gramatici.

Širi znanstveni doprinos istraživanja ogleda se u pružanju teorijsko-metodološkog pristupa namijenjenog proučavanju i analizi komunikacije u cyber-prostoru, ukazivanju na dijakronijske procese na diskursnoj razini, te isticanju nužnosti za funkcionalnim teorijama jezika.

Ključne riječi: pragmatika, analiza diskursa, konverzacijska analiza, cyber-komunikacija, suvremena pismenost, jezična evolucija, filozofija jezika, diskursne oznake, poštapalice, šutnja 


\section{EXTENDED (STRUCTURED) ABSTRACT}

Central theme of this work would be the category of discourse markers, which were produced and analysed in the context of cyber communication. In order to adequately analyse them, it was necessary to rely on theorethical and methodological bricolage assembled of various pragmatic, sociolinguistic and semiotic approaches. Finally, category of discourse markers was analysed both from synchronic as well as diachronic perspective.

Before we go into explanation of basic problems appearing in this work, here is a brief look into its structure. First chapter is introductory in its nature, here the reader is being introduced with the basic structure of the material, as well as main concerns and topics dealt throughout the dissertation. Second chapter aims to connect its central topic - the category of DMs, with the context of investigation - the cyber context. The following chaper (chaper 3) deals with Cyber pragmatics - a new field proposed by the authors, in order to provide an adequate theorethical and methodological frame for the analysis of cyber communication. Chapter 4 investigates main problems of discourse markers which appear in synchrony. Those problems are the following: terminological problems, definition problems and criterial problems (which in turn define the category). With the fifth chapter, the focus of investigation moves to diachrony. Specifically, to the area of historical pragmatics, gestural theories of language evolution and changes in language on a discourse level. Investigation of language change in discourse was central here and it was exemplified with formation and evolution of DMs. The following chapter (chapter 6) aims to investigate the influence of technology on communication and its efficacy. Here we have brought about the hypothesis verification, a short discussion on creativity and a list of principles of Cyber pragmatics as a new disciplinary field. Finally, seventh chapter summarizes the most important results and new findings obtained by the analysis, and it brings about some main difficulties and ideas for the future.

Discourse markers (DMs) are defined here as a functional category of connective devices which can have various different roles in utterance interpretation. Although scholars do agree on some of their main characteristics, such as the cohesive force which enables them to tie together different sections of discourse, a consensus yet needs to be reached on how to delimit the very category in question. If syntax is considered, it's easy to see that the class of DMs is extremely heterogenous as it may contain: interjections, adverbs, conjuctions, adverbial 
phrases, verbs, sentence clauses and even entire sentences. That could be one possible source of the terminological mess occupying this area of inquiry, where discourse markers have also been referred to as: discourse particles, discourse operators, pragmatic markers, discourse connectives, connective phrases etc. For the reasons mentioned, the problem of defining discourse markers will be dealt with the help of functional criteria, since they are considered to be a functional pragmatic category.

Nevertheless, there are several formal features of discourse markers which are being mentioned in various theories, and are imposing themselves as main and obligatory attributes of this category. Those are connectivity, syntactic optionality, non-truth-conditionality, utterance initiality and multicategoriality. Listed formal criteria have been shown to be useful for diachronic approaches to DMs, whereas the functional ones work better in synchrony.

Next problem addressed here and tightly connected to the evolution of DMs would be the problem of their meaning. For the purposes of this work, we have taken two main types of meaning into consideration. First is the core meaning which represents the basic semantic content of a specific discourse marker and for which is also claimed to exist even in those DMs considered semantically empty. This concept of meaning has proved to be a useful tool for diachronic approches. Nevertheless, while discussing language change on a discourse level, we'll be approaching DMs from much broader perspective of historical pragmatics (not to be limited by syntactic and semantic constraints), giving the process of grammaticalization (Lehmann 1995) and pragmaticalization (Diewald 2011; Heine 2013) a valid account in DM evolution. In accordance with this, we'll be dealing with yet another type of meaning, namely with procedural meaning. This type of meaning represents information encoded in linguistic constructions which tells us how to use conceptual representations in the phase of inferring and comprehension (Blakemore 2002). To be even more precise, procedural meaning is metacommunicative, metapragmatic, metadiscursive, instructional and it is a primary type of meaning for this category, as well as a key tool for synchronic and diachronic approaches of our topic.

The context of this investigation also deserves a few explanatory words. Namely, Computermediated discourse is a type of communication which emerges when people interact by sending messages via networked computers (Herring, 2001: 612). Stated definition is satisfactory, but terminology leaves us with problems. Concepts such as informatic, informational, computer, computational, do not correspond to the content they should be referring to: some are too 
narrow while others are too broad in their meaning coverage. This is the main reason why we are opting for the prefix/adjective cyber while discussing online communication and discourse. Other reasons would also be of pragmatic nature: economy of the term (cyber discourse is much shorter than computer-mediated discourse), lexical productivity (the term is very prolific in the domain of new word formation, e.g. cyberspace, cyberfeminism, cybersociology etc.) and frequency in everyday language use (people use it more and understand it better).

Cyber discourse would be a term with especially broad spectrum of meaning because it covers all types of communication on the Internet: from blogs, e-mails, through forum discussions, virtual reality interactions, to chats and instant messaging. Research dealing with cyber discourse is a part of a larger field known as Computer-mediated communication (CMC). Here, the focus is put on online language use by implementing methodology of discourse analysis, conversation analysis and interactional sociolinguistics. To complement that, we have added a functional approach to grammar (Functional Discurse Grammar) as well as some aspects of philosophy of language (Coyne 1998, Wittgenstein 1953, Vlăduţescu 2013) by which we define cyber pragmatics as a multidisciplinary research of online communication.

This theoretical and methodological frame has been chosen because of the nature of the media of communication under scrutiny. To be more precise: the Internet is very fluid (prone to change, intertextuality, multimodality and open access), it doesn't hinder language use and it encourages langauge creativity. On the other hand its lack of paralanguage, its asinchronicity and spatial decontextualization (non-existence of a shared physical context between speakers) hinder coherence and cohesion, language economy and signalization of language functions. All those factors have created ideal surroundings for the developement and proliferation of discourse markers, as an inexhaustible source of original everyday laguage use which hasn't been subjected to alteration, niether for methodological nor linguopolitical reasons.

Main goals of this research would be the following: a) delimiting the category of discourse markers, b) emphisizing the epistemological problems in the science of linguistics, c) indicating diachronic (evolutionary) processes which occur on a discourse level, d) accentuating the necessity for functional language theories in order to expand traditional grammar.

Finally, the very analysis has been conducted on a private corpus holding 600 online conversations in a form of instant messaging (via Hangouts, Facebook messenger, Whatsapp applications) and on the examples chosen from a public Croatian Web Corpus ( $h r W a C$ ). 
Methodologically and theoretically, the analysis has been supported by conversation analysis, pragmatics, language philosophy, discourse analysis and functional (discourse) grammar.

Key words: pragmatics, discourse analysis, conversation analysis, cyber communication, contemporary literacy, language evolution, philosophy of language, discourse markers, prop (crutch) words, silence 


\section{SADRŽAJ}

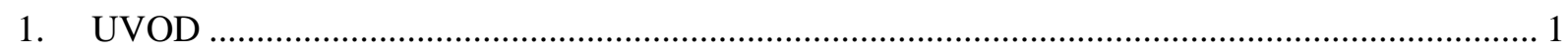

2. KOMUNIKACIJSKA KOMPETENCIJA U CYBER-SVIJETU …............................................... 3

2. 1. Diskursne oznake i koordiniranje komunikacijskog procesa ............................................. 10

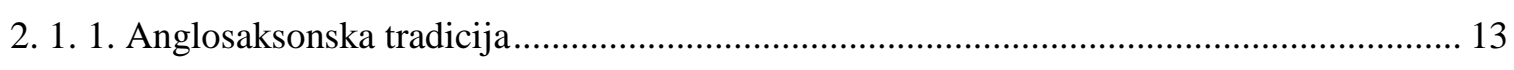

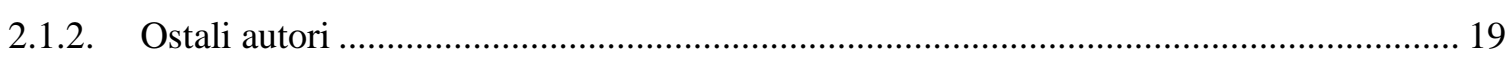

2.1.3. Domaće i regionalno jezikoslovlje i slučaj diskursnih oznaka ...................................... 20

2. 2. Novom perspektivom kroz stare probleme (ciljevi i svrha istraživanja) .................................. 28

2. 3. Pretpostavke i povezanost cyber-konteksta i diskursnih oznaka ............................................ 31

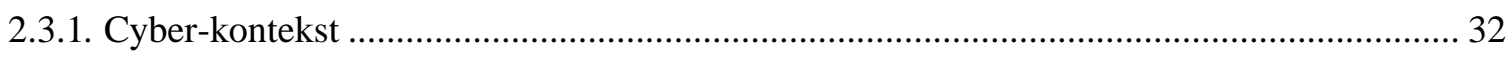

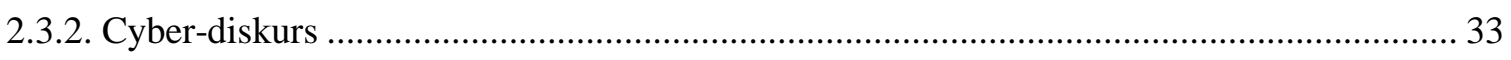

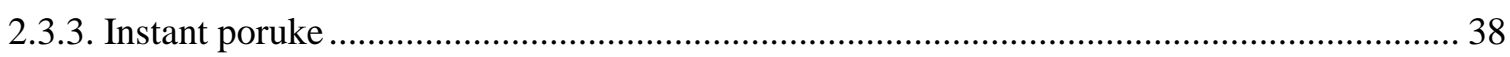

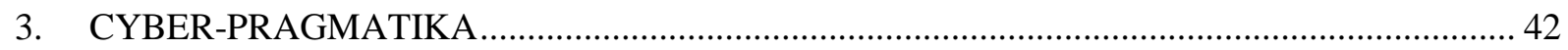

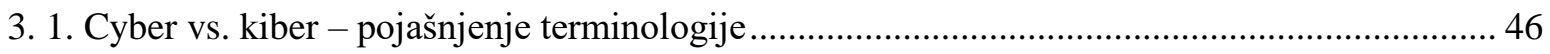

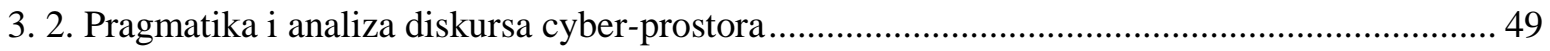

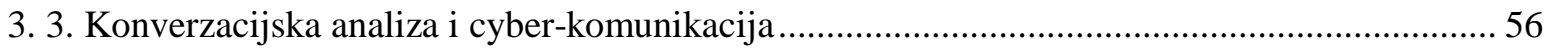

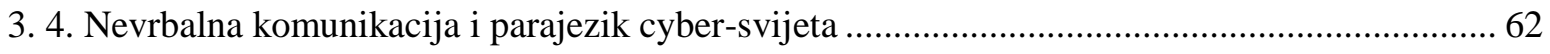

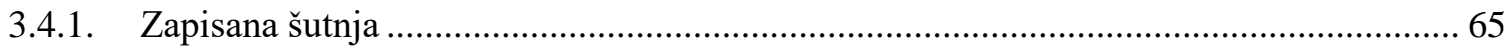

3. 5. Diskurs i gramatika - funkcionalna (transfrastička) gramatika? .............................................. 69

3.5.1. Pražani i funkcionalna rečenična perspektiva............................................................... 70

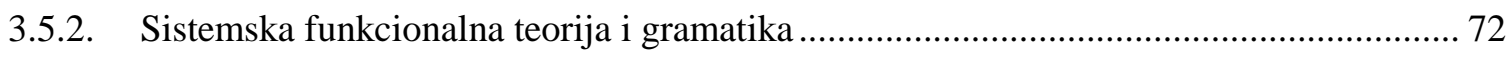

3.5.3. Tekstna lingvistika i njezini doprinosi funkcionalnom pogledu na jezik ........................ 73

3.5.4. Funkcionalna diskursna gramatika - na razmeđi između forme i funkcije ..................... 74

4. KATEGORIJA DISKURSNIH OZNAKA - primjeri s mreže .................................................... 82

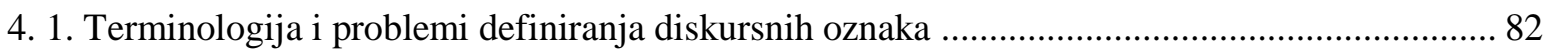

4. 2. Utvrđivanje formalnih kriterija za pripadnost kategoriji diskursnih oznaka ............................ 85

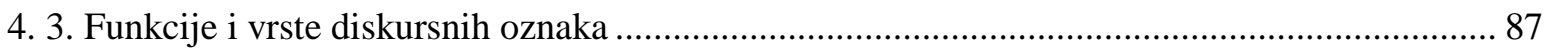

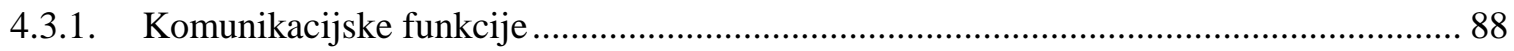

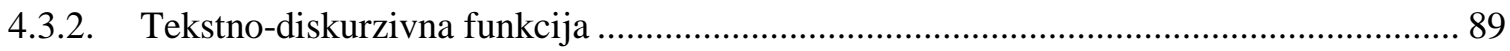

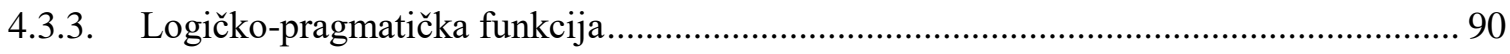

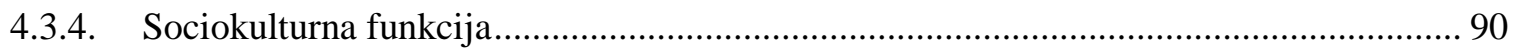

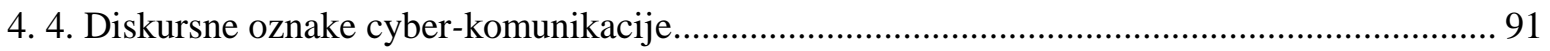

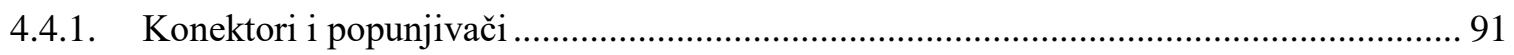


4.4.2. Interaktivi i modifikatori. .. 93

4.4.3. Opis uzorka - ciljni (privatni) korpus i referentni korpus hrWac............................96

4.4.4. Etičke reperkusije dvostruke uloge istraživača..................................................... 100

DISKURS I EVOLUCIJSKA PRAGMATIKA - jezični razvoj kao posljedica (u)potrebe ............... 103

5 .1. Od utjelovljene spoznaje prema bestjelesnoj komunikaciji ........................................... 106

5.1.2. Gestovna teorija jezičnog porijekla ................................................................ 108

5.1.3. Posredovana gesta - specifičnost cyber-komunikacije.......................................... 110

5. 2. Diskursne oznake kroz prizmu povijesti ............................................................ 114

5.2.1. Problem značenja diskursnih oznaka ................................................................ 118

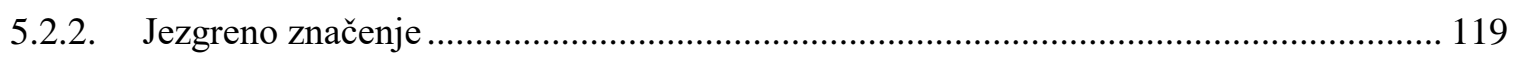

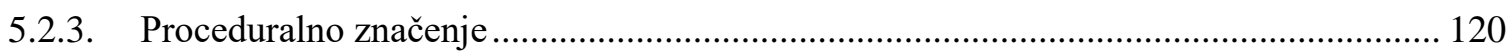

5. 3. Jezične promjene na diskursnoj razini................................................................... 121

5.3.1. Gramatikalizacija vs. pragmatikalizacija ........................................................ 121

5.3.2. Obilježja procesa gramatikalizacije diskursnih funkcija ....................................... 122

5.3.3. Problem (inter)subjektifikacije .............................................................. 127

5. 4. Evolucija diskursnih oznaka u cyber-komunikaciji................................................... 129

4.4.5. Diskursne oznake vs. poštapalice ................................................................. 131

4.4.6. Diskursne oznake vs. dijalogičnost šutnje ....................................................... 135

5. „MEDIJI KAO ČOVJEKOVI PRODUŽECI” ILI BUKA U KOMUNIKACIJSKOM KANALU?

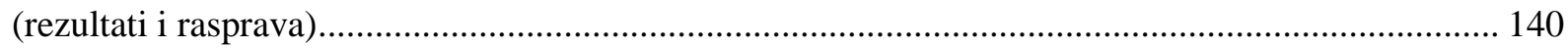

6. 1. Diskursne oznake - moderatori u kaosu iskaza (interpretacija kvalitativnih podataka i

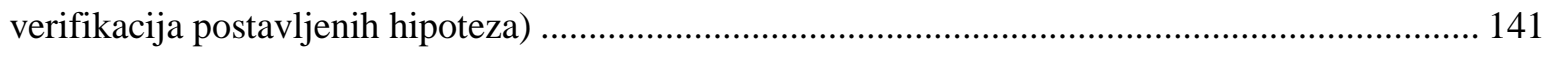

6. 2. Kreativnost, pragmatizam i sociosemiotika cyber-komunikacije.................................... 143

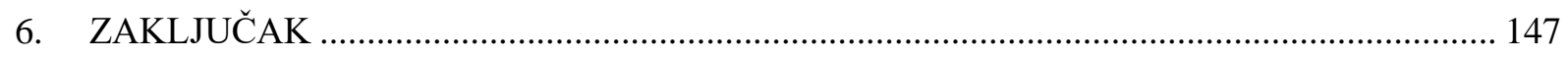

7. 1. Najvažniji rezultati i nove spoznaje ........................................................................... 147

7. 2. Glavne poteškoće i sugestije za buduća istraživanja ................................................ 150

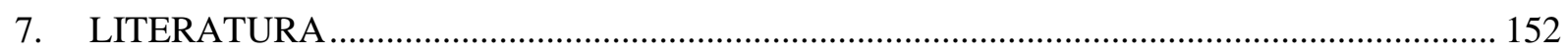

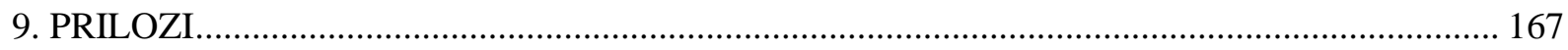

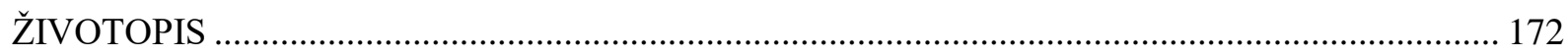




\section{UVOD}

Generalno govoreći, diskursne se oznake (DO-e $\left.{ }^{1}\right)$ mogu definirati kao funkcionalna kategorija vezivnih izraza s mnoštvom različitih utjecaja na interpretaciju iskaza. Uz navedenu se definiciju u literaturi može naići na brojne druge, no same definicije naravno ovise o njihovim autorima, tj. o raznovrsnim teorijsko-metodološkim polazištima.

Prvi dio rada otvorit će problematiku pružanjem ostenzivne definicije diskursnih oznaka. S obzirom na to da su neke od najprepoznatljivjih diskursnih oznaka svakodnevne, neformalne, interpersonalne cyber-komunikacije hrvatskog jezika kratice i imitativi, primjeri mogu biti neki od sljedećih: kratice poput msm (mislim), ugl (uglavnom), jbt (jebote) i imitativi poput hmm, ahahaha i kmee koji u cyber-kontekstu ponajprije služe za koordinaciju razgovora, isticanje stavova, te iskazivanje emotivnih stanja. Pojasnit ćemo s pomoću još jednog primjera. Primimo li na kraju mrežnog razgovora poruku koja glasi: “ugl, i kj ćemo na kraju dns?!”, ugl ćemo dekodirati kao element koji naš razgovor i našu pažnju kao sugovornika vraća na pročetnu problematiku: dogovaranje o planovima za današnji dan. Zasigurno tu kraticu nećemo razumijeti kao prilog uglavnom (iako od njega potječe diskursna oznaka $u g l$ ) koji u rečenici: „Danas sam se uglavnom odmarala.” još uvijek označava učestalost obavljanja neke radnje (što nije slučaj u prvom primjeru). Do kakvih je ovdje promjena došlo, bit će više riječi nešto kasnije kada se dotaknemo dijakronijskog razvoja kategorije DO-a (poglavlje 5). Kad je pak riječ o sinkronijskim značajkama diskursnih oznaka, pozabavit ćemo se najistaknutijim odlikama kategorije, kao i teorijsko-metodološkim doprinosima prominentnih autora koji su se bavili problematikom diskursnih oznaka (poglavlje 2. i 4).

Drugo i treće poglavlje problematizirat će specifični kontekst istraživanih jezičnih razmjena i fenomena koji su ondje nastali: kontekst cyber-komunikacije. Također, osvrnut ćemo se na terminološke i sociopragmatičke probleme izazvane nastankom i upotrebom novih tehnologija (poglavlje 5).

S ciljem ukazivanja na određene epistemološke probleme unutar struke, ovom smo problematikom dotaknuli i vječno pitanje odnosa gramatike i diskursa te ponudili neka potencijalna riješenja (poglavlje 3.3). Također, inspirirani promjenama na diskursnoj razini,

\footnotetext{
${ }^{1}$ Od sada pa nadalje u tekstu će se naizmjenice upotrebljavati pokrata DO-a sa značenjem diskursna oznaka.
} 
dodali smo raspravu o značaju pragmatičkih (uporabno-funkcionalnih) pristupa za teorije jezične evolucije (poglavlje 5.1).

Rad se zaključuje sociosemiotičkim pristupom cyber-komunikaciji kojim se u prvi plan stavlja heterosemiotičnost suvremene komnunikacije (poglavlje 6). 


\section{KOMUNIKACIJSKA KOMPETENCIJA U CYBER-SVIJETU}

Koncept opće komunikacijske kompetencije, pa tako i one specifične (u ovom slučaju komunikacijske kompetencije cyber-svijeta) odnosi se na posjedovanje sposobnosti uspješnog komuniciranja. Međutim, pojam kompetencije iz nekoliko je razloga postao spornim u domeni općeg i primijenjenog jezikoslovlja (Bagarić i Mihaljević Djigunović 2007: 84), te ga treba upotrebljavati s oprezom. Povrh svega, uspješnost cyber-komunikacije zahtijeva i određen stupanj računalne pismenosti koja danas čini integralni dio sveopće komunikacijske kompetencije te joj je potrebno posvetiti nekoliko riječi. No, kao što ćemo vidjeti, i ovaj se koncept računalne pismenosti mijenjao kroz vrijeme, ali njegov je razvoj išao ukorak s razvojem digitalnih tehnologija.

Uvođenje termina "kompetencija" u područje lingvistike obično se pripisuje Avramu Noamu Chomskom, koji je u svojoj knjizi iz 1965. Aspects of the Theory of Syntax uveo razliku između jezične sposobnosti (engl. competence) i jezičnog izvođenja tj. kontekstualizirane upotrebe jezika (engl. performance). Chomsky je kompetenciju ovdje definirao kao urođeno znanje o apstraktnom jezičnom sustavu, kao predispoziciju za usvajanje jezika i kao generativnu sposobnost ljudskog uma koja se ogleda u proizvodnoj moći jezičnog sustava, posebice na razini sintakse (rekurzivnost). Glavni je ,akter” ovdje idealni govornik-slušatelj. S druge strane, stvarna jezična upotreba ovisna je o kontekstu i govornicima-slušateljima koji su daleko od idealnih, što Chomsky isključuje iz domene teorijske lingvistike kao balast ili smetnju objektivnoj znanstvenoj spoznaji. Ipak, samo proučavanjem te nesavršene upotrebe jezika koja nam je jedina izravno dostupna, možemo doći do podataka o ideal-tipskom, apstraktnom jezičnom sustavu koji se skriva u umu čovjeka. Naposljetku njihov je odnos dijalektičan. No ako se ustraje na podjeli Chomskoga, kompetencija bi spala u oblast gramatike, dok bi jezična upotreba pripala domeni pragmatike.

Razmislimo li još jednom i vratimo li se na početak 20. stoljeća, vidjet ćemo da je Saussure bio na tragu sličnih distinkcija, no one su ponajprije bile motivirane formiranjem lingvistike kao autonomne znanosti. Ne bi li u tome uspio, Saussure je za početak izdvojio njezin specifičan i jedinstven predmet proučavanja: jezik, razloživši jezičnu djelatnost (franc. langage) na jezik (franc. langue) i govor (franc. parole). Pri tome je naglasio da je predmet lingvistike jezik, ali 
i da se utjecaj govora na jezik ne smije zanemariti jer upotreba mijenja sistem kao što i sustav određuje izvedbu.

Ako se vratimo na Chomskog, u njegovu nešto kasnijem radu od prethodno navedenog, radu iz 1986. pod nazivom Knowledge of Language, on uvodi distinkciju između I-jezika i E-jezika. I-jezik $^{2}$ je prema Chomskome interan, individualan i intenzionalan, a E-jezik bila bi njegova vanjska realizacija (engl. external and extensional), tj. jezik koji ima ekstenziju u stvarnosti. Navedena razlika također nije originalna ideja Noama Chomskog, već se vezuje za ime drugog velikana, Wilhelma von Humboldta, jednog od predstavnika predstrukturalističke misli. Humboldt je još krajem 19. stoljeća uočio dualističnu prirodu jezika, istaknuvši razlikovanje unutarnje i vanjske forme koja je inspirirala uvođenje razlike između I-jezika i E-jezika. Ono što Humboldt ovdje ističe jest da je unutarnja forma intelektualni dio jezika, do jedne mjere jednaka u svim ljudima, tj. da je ondje zadržana veća jednoobraznost nego u glasovnoj (vanjskoj) formi. Prema Chomskom je upravo ta jednoobraznost razlog zašto bi se lingvistika trebala ponajprije baviti sistemom, a ne njegovim ostvarajem.

Takvi stavovi izazvali su brojne kritike, a kritičari Chomskog počeli su tragati za alternativnim, širim i realnijim pojmom kompetencije. U prvom je redu riječ o pojmu komunikacijske kompetencije Della Hymesa (1972) kao centralnog pojma njegove etnografije komunikacije. Za razliku od Chomskog, Hymes smatra da je komunikacijska kompetencija stečena procesom komunikacijske interakcije (oblikom socijalnog učenja u kontekstu govorne zajednice). Osnovne sastavnice ovako shvaćene komunikacijske kompetencije Hymes je pobrojao u akronimu SPEAKING (od engleskog setting and scene, participants, ends, act sequences, keys, instrumentalities, norms and genres) (Hymes 2006: 46). Ako se bolje pogleda, ovdje se radi o komponentama komunikacijskog lanca stavljenima u društveni kontekst, a u hrvatskom bi prijevodu to bile sljedeće sastavnice: kontekst (vrijeme i mjesto), sudionici, ciljevi, nizovi (govornih) činova, ključevi (koji dočaravaju atmosferu komunikacije), sredstva (upućuju na komunikacijski kanal i korišteni registar), norme i žanrovi. Jasno je da je time znatno prošireno čomskijansko shvaćanje kompetencije i osnaženo sociolingvističkim i pragmatičkim saznanjima.

\footnotetext{
${ }^{2}$ I-jezik je prema Chomskome sustav jezičnog znanja usvojen i internaliziran, tj. smješten u ljudskom umu. On je apstraktan i navodi se pravilima generativne gramatike. I-jezik proizvodi E-jezik koji je vanjski našem umu. On je također apstraktan, no to je jezik shvaćen u tradicionalnom smislu, kao znakovni sustav upotrebljavan za komunikaciju u određenoj društvenoj zajednici.
} 
U tome je nizu Widowson krajem 70-ih godina 20. stoljeća napravio razliku između kompetencije (engl. competence) i sposobnosti (engl. capacity), pri čemu kompetenciju smatra znanjem lingvističkih i sociolingvističkih pravila, a sposobnost vještinom primjene tih znanja s ciljem stvaranja ili tumačenja značenja. Po njegovu se mišljenju sposobnost ne razvija iz kompetencije, već ostaje neovisnom, kreativnom snagom.

Sintetički pristup problematici demonstrirali su Canale i Swain (1980) i Canale (1983), gledajući na komunikacijsku kompetenciju kao na spoj temeljnog sustava znanja (sastavljenog od triju vrsta znanja: znanja gramatičkih pravila, društvenih normi i pragmatičkih principa) i vještina (tj. umješnost u primjeni navedenih znanja) potrebnih za komunikaciju. Savignon (1972) shvaća komunikacijsku kompetenciju slično prethodnim autorima, no zbog obilježja dinamičnosti koje joj pripisuje, njezina se definicija vrlo dobro uklapa u kontekst cyberkomunikacije:

„... sposobnost djelovanja u pravom komunikacijskom okruženju." „... dinamična razmjena u kojoj se lingvistička kompetencija treba prilagoditi cjelokupnom informacijskom ulazu, lingvističkom i paralingvističkom, koji pruža jedan ili više sugovornika.”

Naposljetku, Taylor je 1988. predložio zamjenu termina „komunikacijska kompetencija” terminom „komunikacijsko umijeće” (engl. communication proficiency).

Kada sva navedena viđenja komunikacijske kompetencije primjenimo na kontekst cybersvijeta, neminovno ćemo se zapitati što se to mijenja u strukturi potrebnog znanja za uspješnu mrežnu komunikaciju, te koje se prepreke javljaju a koje potiču na kreativnost i razvijanje umijeća.

Ako pratimo Canaleovu podjelu znanja na tri tipa, nameće se pitanje koji to tipovi znanja podliježu promjenama i kako se taj pomak manifestira u jezičnoj upotrebi. Promatranjem cyberkomunikacije već na površini možemo uočiti da se znanje gramatičkih pravila nadograđuje znanjem mrežnog jezika koji je heterosemiotičan (npr. upotreba emotikona i brojnih skraćenica). Znanje društveno-komunikacijskih normi ostaje isto, no njihovo poštivanje i implementacija postaje mnogo labavija (npr. pseudoidentiteti, ghosting ${ }^{3}$, lurking ${ }^{4}$ ), također znanje pragmatičkih principa u upotrebi prilagođava se prirodi medija (npr. u mrežnim

\footnotetext{
${ }^{3}$ Praksa iznenadnog povlačenja i nestajanja iz komunikacije s ciljem prekidanja osobnih odnosa (bez neugodnosti i bez preuzumanja odgovornosti). Od engleske riječi ghost, u značenju duha, tj. u značenju nestati kao duh.

${ }^{4}$ Od engl. to lurk ili uhoditi koga. U domeni komunikacije na internetu to je praksa promatranja komunikacije i sakupljanja informacija, no bez osobnog sudjelovanja i bez znanja drugih.
} 
razgovorima kršenje maksime relevantnosti češće je pravilo nego iznimka, ponajprije zbog drugačije percepcije i korištenja dimenzije vremena, posebice zbog tehnoloških nedostataka ${ }^{5}$ ).

No, govoreći o znanjima potrebnim za komunikacijsku kompetenciju u cyber-svijetu, zapravo se dotičemo još jednog problema: pitanja tzv. računalne ili cyber-pismenosti. Cyberpismenost se tijekom vremena percipirala (pa tako i definirala) na posve različite načine. Sve različite perspektive posljedica su iznimno brzog razvoja računalne tehnologije i uočavanja novih mogućnosti njihove primjene. Kay (1992) stoga navodi šest različitih perspektiva o cyber-pismenosti od kojih se prva pojavila sedamdesetih godina 20. stoljeća, dok posljednja traje još i danas.

Prva perspektiva izrodila se iz prve faze korištenja računala koja je sedamdesetih godina prošog stoljeća bila rezervirana za sveučilišnu elitu. Tada se cyber-pismenošću smatralo poznavanje teorijskih koncepata o računalima, a na to se referiralo kao na „,svijest o računalima” (engl. computer awareness). Ovaj je pristup naišao na brojne kritike zbog zanemarivanja upotrebe računala.

Druga je faza započela 1978., pojavom mikroračunala. To je rezultiralo uvođenjem novog kriterija za određenje cyber-pismenosti: sposobnosti pisanja računalnih programa, jer su vještine programiranja tada bile jedini način upravljanja računalima.

Sljedeća faza stupa na snagu osamdesetih godina 20. st. zbog naglog rasta i razvoja računalnog hardvera i softvera. Takav je tehnološki napredak nagnao znanstvenike na ponovno preispitivanje pojma cyber-pismenosti, pri čemu su se iskristalizirale dvije struje:

a) Ona koja cyber-pismenost smatra konceptom koji se razvija, evoluira tijekom vremena. Autori su se ovdje većinom bavili pregledom povijesnih perioda računalnog razvoja i koncepta cyber-pismenosti.

b) Perspektiva koja se okrenula prema budućnosti, ponajprije u vidu planiranja. Predstavnici ove struje predlagali su održavanje radionica za korisnike, formiranje korisničkih službi za rješavanje problema od strane računalnih stručnjaka i provođenje istraživanja vezanih za interakciju čovjek-računalo.

\footnotetext{
${ }^{5} \mathrm{Za}$ više informacija vidi Susan Herring (2013.) „Relevance in Computer-mediated Communication“.U: D. Stein, \& T. Virtanen (Ur.), Handbook of pragmatics of computer-mediated communication (str. 245-268). Berlin: Mouton de Gruyter.
} 
Četvrta faza javlja se polovicom osamdesetih i ukratko se može opisati kao bihevioralna jer naglasak stavlja na upotrebu računala kao oruđa. U ovome je periodu iznimno zanimljivo Gabrielovo (1985) razlikovanje računalne pismenosti od računalne znanosti. Pri tome autor u pismenost ubraja vještine rješavanja problemskih zadataka, interakcije $\mathrm{s}$ računalima, poznavanja funkcija računala i njihove upotrebe te razumijevanje utjecaja računala na društvo. $\mathrm{S}$ druge strane $\mathrm{u}$ domenu računalne znanosti ubraja vještine programiranja, poznavanja funkcioniranja hardvera i poznavanje operacija softvera.

U petoj se fazi razrađuju ideje prethodnog razdoblja, s velikim naglaskom na percepciji računala kao oruđa i orijentacijom prema korisniku kome se upotreba tog oruđa nastoji olakšati. Zbog toga dolazi do prve pojave programa prilagođenih korisniku, lakih za upotrebu (engl. user-friendly softwares). Od korisnika se ovdje zahtijevaju samo osnovne vještine čitanja i tipkanja. To je navelo znanstvenike na ponovno propitivanje pojma cyber-pismenosti iz kritičke perspektive i otvorilo je još jedno pitanje: za što nam zapravo trebaju računala?

Posljednja faza nadovezuje se na prethodno pitanje, no fokus se pomiče s globalnog na individualizirano shvaćanje cyber-pismenosti, što izvrsno ocrtava citat od Kay (1992: 6):

,$\ldots$ no one individual could possibly acquire all the skills necessary to run a computer in every conceivable way."

Drugim riječima, cyber-pismenost ovdje se svela na zadovoljavanje osobnih potreba upotrebom računala.

„A definite shift has occurred from focusing on computer literacy to focusing on what computers can do to achieve certain desires." (Kay, 1992: 7)

Danas gotovo da nije više potrebno učiti kako se upotrebljava računalo, već je potrebno znati za što ga primijeniti, zaključuje Kay.

Ipak, ne bi bilo mudro posve odbaciti koncept cyber-pismenosti ni u kojem obliku, čak ni onome posve individualiziranom (koji ujedno i odgovara ideologiji neoliberalnog, suvremenog kapitalističkog društva) jer i takav tip pismenosti zahtijeva posjedovanje određenih vještina i znanja. Mnogi, posebice oni rođeni u društvu digitalne tehnologije, nisu svjesni tih znanja i vještina jer su ih internalizirali u svakodnevnoj upotrebi, bez formalnog školovanja. No njihov manjak vidljiv je kod starijih generacija koje ih nisu (u potpunosti) usvojile i na koje katkada gledaju sa skepsom i odbijanjem zbog straha od nepoznatog i novog. Upravo iz th razloga, kao 
i onih kojih smo se dotakli raspravljajući o pojmu opće komunikacijske kompetencije, rekli bismo da je u suvremenom informacijskom društvu cyber-pismenost njezin punopravni dio.

Danas se cyber-pismenost može smatrati sposobnošću učinkovite upotrebe računalnih tehnologija (za suvremenu komunikaciju), uz istovremeno razumijevanje (mogućih) posljedica tih istih akcija. Njezin je drugi vrlo bitan faktor vještina pronalaska i odabira pouzdanih informacija u cyber-prostoru. Prateći tu pretpostavku, Laura J. Gurak (2001) u svojoj knjizi o cyber-pismenosti navodi da cyber-pismenost uključuje sljedeće vještine, znanja i sposobnosti:

a) sposobnost prosuđivanja legitimnosti mrežne stranice,

b) sigurno traženje i pretraživanje podataka (npr. antivirusne prakse i uočavanje prevara),

c) sposobnost praćenja i održavanja interakcije u nelinearnom razgovoru, u tzv. postovima ili instant-porukama,

d) znanje o tome koju je informaciju sigurno podijeliti na društvenim mrežama,

e) svjesnost o prirodi vremena u prostoru tokova (Castells, 2000) i svih mogućih posljedica koje ono nosi sa sobom,

f) svjesnost o mrežnim postupcima i njihovim motivacijama,

g) elektronička, ne samo računalna pismenost,

h) postizanje željenog dosega anonimnosti, interaktivnosti i brzine.

Svih osam navedenih vještina, znanja i sposobnosti možemo dalje podijeliti u tri osnovne nadskupine kriterija, tj. elemenata pismenosti: one tehničke naravi (npr. elektronička pismenost), atehničke (npr. sposobnost praćenja i održavanja interakcije u nelinearnom razgovoru) i etičke ${ }^{6}$ naravi (npr. svjesnost o mrežnim postupcima i njihovim motivacijama).

Iz navedenih se kriterija jasno vidi koji su aspekti opće komunikacijske kompetencije najviše pogođeni, pa tako i modificirani prirodom interneta kao medija. Riječ je prije svega o domeni društvenih normi koje su shvaćene mnogo opuštenije u cyber-prostoru ${ }^{7}$ i time zahtijevaju prilagodbu korisnika (ponajviše u vidu kritičkog mišljenja i opreza). S druge strane, izostanak

\footnotetext{
${ }^{6} \mathrm{O}$ etičkim aspektima cyber-komunikacije prvi je pisao Norbert Wiener u svojoj knjizi The Human Use of Human Beings $(1950,1954)$. Njegovi uvidi u etičke probleme koje su sa sobom donijele inforamcijskokomunikacijske tehnologije još uvijek stoje, i s pravom se smatra ocem računalne informacijske etike. Zanimljivo je da je i prvi uočio problem hakerskih napada, kršenja autorskih prava i kršenja pravila privatnosti. ${ }^{7}$ Više o odlikama cyber-prostora pogledaj u poglavlju 2.3., u podnaslovima „Cyber-kontekst“" i „Cyber-diskurs“"
} 
zajedničkog fizičkog konteksta $^{8}$ i dominacija vizualnog ${ }^{9}$ kanala u odnosu na ostale, donijela je promjene u domeni pragmatike, što se prelilo u područje gramatike mrežnog jezika (npr. emojis, emoticons, kratice, imitativi itd.). Upravo su u tim gramatikama na mreži i diskursne oznake pronašle nišu za sebe, kako napominje Dolić (2016: 31) posebice u onima engleskog jezika, namijenjenima za strance. $U$ takvim se gramatikama, poput one Cambridgeove ${ }^{10}$, diskursne oznake opisuju kao izrazi s četrima osnovnim funkcijama: funkcijom povezivanja diskursa i funkcijom organiziranja diskursa, zatim kontroliranja već iskazanog i funkcijom izražavanja stava. No, razmislimo li zašto su baš u sklopu mrežnih gramatika diskursne oznake pronašle mjesto za sebe, odgovor možemo pronaći u samom pojmu cyber-pismenosti, tj. u obilježjima cyber-diskursa, suvremene komunikacije i digitalne tehnologije. Naime, zbog manjka fizičkog konteksta pri cyber-komunikaciji umnaža se potreba za korištenjem i razumijevanjem diskursnih oznaka. Digitalizirane gramatike tu pojavu uvažavaju jer se često odnose na stvarnu jezičnu upotrebu gdje diskursne oznake "obitavaju”. Također, gramatike ovog tipa lakše se i češće ažuriraju.

Zaključno se stoga može ustvrditi da je komunikacijska kompetencija suvremenog doba svoju domenu uspješno proširila na digitalne medije. Pred korisnike je time postavljen zahtjev za formiranjem i usvajanjem novog oblika pismenosti: cyber-pismenosti kojom su obuhvaćeni njezini tehnički i atehnički, no i etički elementi. Naposljetku, teleprisutnost cyber-komunikacije svojim je sudionicima oduzela zajednički fizički kontekst često koordiniran neverbalnom komunikacijom, što se u cyber-diskursu kompenziralo povećanom upotrebom diskursnih oznaka i naglašenom heterosemiotičnošću.

\footnotetext{
${ }^{8}$ Ovo je obilježje posljedica zamjene tjelesne suprisutnosti govornika s njihovom teleprisutnošću. Teleprisutnost je posljedica komunikacije na daljinu, što znači da je takav tip komunikacije osiromašen u smislu fizičkog konteksta, no njome se otvara prostor za isključivo diskurzivnu izgradnju identiteta i značenja.

${ }^{9}$ Vizualni je kanal u novim medijima mnogo više eksploatiran nego u tiskanim medijima poput knjige. Osim teksta i statične slike često se upotrebljavaju različiti simboli, videosnimke i gifovi. Također, mnogo je lakše sam postati izvornim autorom ili urednikom takvog sadržaja (za razliku od autorstva u masovnim medijima), što umnaža njihovu količinu unutar nekog teksta i utječe na dojam koji taj tekst ostavlja.

${ }^{10}$ Dostupno na URL: https://dictionary.cambridge.org/grammar/british-grammar/discourse-markers-so-rightokay (19. siječnja 2020.)
} 


\section{1. Diskursne oznake i koordiniranje komunikacijskog procesa}

$\mathrm{S}$ obzirom na prostornu (ponekad i vremensku) razliku u kontekstima sudionika komunikacije na mreži, diskursne oznake u cyber-svijetu igraju iznimno veliku ulogu u pragmatičkom procesu interpretacije iskaza. Hassan i Hashim (2009) ih s opravdanim razlogom stoga izdvajaju kao jednu od sedam osnovnih karakteristika komunikacije na mreži (uz prebacivanje i miješanje kodova, kratice i akronime, posuđenice, afiksaciju te stapanje i slaganje). Autori ističu da je popularnost upotrebe diskursnih oznaka u cyber-komunikaciji proizašla iz činjenice da one zamijenjuju jezične funkcije koje obično prenosi intonacija i/ili tradicionalna gramatika jezičnog standarda (Hassan i Hashim 2009: 43). S obzirom na to da se radi o oraliziranom tekstu, kako ga naziva Yus (2011), intonacija se mora dočarati drugim sredstvima (izvan zvučnog kanala). Jednako tako, tradicionalne nam gramatike tu neće pomoći jer ne prelaze razinu sintakse i nisu opremljene da objasne integraciju nadrečeničnih sastavnica čime se ostvaruje diskursna koherentnost.

Iako njihovo proučavanje nije novost, radovi su ove tematike još uvijek relativna rijetkost u okviru cyber-komunikacije. Iznimka bi bila neka od sljedećih istraživanja. Studija o slučaju upotrebe tagaloškog i engleskog te njegovim diskursnim oznakama u komentarima na društvenim mrežama (Palacio i Gustilo 2016), rad J. Parka o ostvarenju društvene i diskursne kohezivnosti u mrežnim razgovorima (2007), studija Lowa i Deteringa (2003) o singapurskim diskursnim oznakama na mreži, upotreba malezijskih DO-a na Facebooku (Tay et al. 2012) te komparativna studija Funga i Cartera (2007) o bilingvalnoj mrežnoj upotrebi engleskih i kantonskih kineskih diskursnih oznaka. U odnosu na tradicionalne pristupe diskursnim oznakama koje vlastite korpuse za analizu temelje ili na govoru ili na tekstu, proučvanje DO-a u cyber-komunikaciji koja se smatra „govorenim tekstom” dodatno ističe njihove funkcije i relevatnost.

Prema našem sudu, specifičnosti računalno-posredovanog diskursa (zbog prirode internetskog medija) mogu nam pružiti nov kut gledišta na problematiku diskursnih oznaka i dovesti do boljeg shvaćanja njihova nastanka, funkcija i statusa. 
Primjer 1: Transkript razgovora vođenog s pomoću aplikacije Whatsapp. Diskursne su oznake napisane crvenim slovima i znakovima. Originalni prikaz razgovora dostupan je u prilozima (prilog 1)

T: kaj ima? Si ziva?

$\mathbf{J}: \mathrm{Ej}$

J: Pa evo čekam da mi stave zimske gume!

J: kaj ti? Zabrijala sam da me izbjegavas!

T: A u karlovcu si, ne izbjevam te, imao sam posla hrpu

J: Ma tu sam do popodne/predvecer, isla sam samo to zbavit

T: Pa super

J: Mogao bi se javit makar za kavu...

J: kjznm

J: kuis! :)

T: Pa evo javio sam se

J: Aha, izgleda da nam tajming nije jača strana $(:)$ !

U općoj rastućoj literaturi diskursne su oznake često navođene i pod drugim imenima. Kao diskursne čestice, diskursni operateri, pragmatičke oznake, diskursni veznici, pragmatički veznici, rečenični veznici i vezivne fraze, što nam odmah ukazuje na činjenicu da konsenzus o njihovu statusu i funkciji još uvijek nije postignut. Osnovni uzrok spomenutoj terminološkoj zbrci može se pronaći u različitim teorijsko-metodološkim polazištima autora. Također, iz prethodnog je primjera (primjer 1) vidljiva i sintaktička i semiološka heterogenost (npr. emotikoni) same kategorije DO-a, koja se preslikala na nazivlje. Stoga bismo mogli reći da pa i $a$ neki autori s razlogom nazivaju diskursnim konektorima ili diskursnim veznicima, $m a$ diskursnom česticom, evo diskursno-deiktičnom jedinicom, trotočje diskursnom ogradom, te kiuš! (kužiš?) i kjznm (kaj ja znam) parentezama ili signalnim frazama. Ipak, bilo bi poželjno kada bi se terminološki usuglasili.

Iako se istraživači slažu oko nekih njihovih osnovnih odlika, poput kohezivne snage kojom vezuju različite dijelove diskursa, još uvijek nije postignut dogovor o tome kako omeđiti njihovu kategoriju. Ako se u obzir uzmu sintaktičke kategorije, lako ćemo uočiti da je klasa DO-a iznimno heterogena jer u nju mogu ući: usklici, prilozi, veznici, priložne fraze, glagoli, sintagme i čitave rečenice. Upravo ćemo se iz tog razloga u ovom radu osloniti na funkcionalne (a ne formalne) kriterije pri njihovu određenju u sinkronijskom presijeku.

Izuzev činjenice da jezični elementi što funkcioniraju kao diskursne oznake dolaze iz vrlo različitih sintaktičkih kategorija, unutar sustava jezika uvijek će postojati identičan jezični 
element koji ne obnaša funkciju DO-a. Taj fenomen usmjerava nas na potencijalni dijakronijski pristup problematici, na proučavanje nastanka i razvoja diskursnih oznaka i njihovo značenje.

Naposljetku, šira perspektiva koja nas okreće ka funkcionalnoj, društvenoj i pragmatičkoj prirodi jezika u upotrebi ključna je za proučavanje kategorije diskursnih oznaka. Ona nam povrh svega pokazuje njihov pretežito proceduralni karakter, neutralnost pri zadovoljavanju istinitosnih uvjeta i ovisnost o društvenom kontekstu. Svim ćemo navedenim karakteristikama nešto kasnije posvetiti više pažnje i razjasniti ih primjerima iz korpusa.

Najuvreženiji i najčešće korišten termin za jezične elemente u pitanju jest termin diskursne oznake, za koji smo se i mi ovdje opredijelili. Sam termin može se shvatiti na dva osnovna načina (ovisno o potrebama analize i teorijskom uporištu): u širem se smislu na DO-e gleda kao na verbalna i neverbalna pomagala (Schiffrin 1987: 40) koja nam pružaju kontekstualne koordinate za tekući razgovor. S druge strane, Fraser (1999) tvrdi da su diskursne oznake pretežito pomagala za povezivanje dijelova diskursa (stoga naziv diskursni veznici), te da su podvrsta kategorije pragmatičkih oznaka ${ }^{11}$ (PO) (Schourup 1999: 238).

Razlike u terminologiji ne staju ovdje, tako primjerice Redeker govori o diskursnim operaterima, definirajući ih kao ,jezične signale tekstne koherentnosti““ (1991: 1139). I za kraj, iako ne manje važan, javlja se termin diskursne čestice (discourse particles, DPs) koji je ponešto problematičan, no zauzimao je drugo mjesto po frekvenciji uporabe sve do sredine 80ih godina 20. stoljeća (Schourup 1999: 229). Kao što smo prethodno naznačili, sam je termin problematičan iz nekoliko razloga: naziv čestica tradicionalno je sintaktički termin, povrh svega neprecizan je jer se klasa čestica i unutar sintakse deifinira negativno, gotovo kao klasa preostalnih riječi koje nisu svrstane u neku od drugih sintaktičkih kategorija. Iako čestice obično obnašaju samo gramatičku funkciju i ogoljene su od svojeg izvorišnog semantičkog sadržaja, pokrivenost sadržaja koju nam pruža termin diskursne čestice nije dovoljno precizan ni iscrpan.

Također, u okviru teorije relevantnosti ponuđena je još jedna perspektiva (nešto drugačija od ostalih) koja se bavi problematikom diskursnih oznaka, a razradila ju je Diane Blakemore (2002). Ona ih naziva diskursnim veznicima i tretira ih kao vrstu Griceovih konvencionalnih implikatura, odbacujući njegovu analizu govornih činova višeg reda i koncentrirajući se na načine na koje one (DO-e) nameću ograničenja implikaturama.

\footnotetext{
${ }^{11}$ Pragmatičke oznake bili bi ,jezično kodirani znaci koji upućuju na potencijalne govornikove komunikacijske namjere.“ (Fraser 1996: 68)
} 
Povijesno gledajući, do velikog povećanja interesa za problematiku diskursnih oznaka došlo je sedamdesetih godina 20. stoljeća. Tada se pobudio interes za pragmatičkim i kontekstualnim aspektima interpretacije iskaza, što je s proširenjem perspektive dovelo i do proučavanja onih elemenata jezične strukture koji povezuju te iskaze na diskursnoj razini. Istraživanja diskursnih oznaka i sličnih pojava nastavila su se u osamdesetima i devedesetima, a danas su se iz domene analize diskursa i pragmatike proširila u područja proučavanja jezičnog usvajanja, jezične pedagogije i sociolingvističkih tema poput rodnih razlika u jezičnom iskazu ili problematike prebacivanja kodova. No s umnožavanjem pristupa, područja, problematika i ciljeva istraživanja u kojima su se pojavljivale diskursne oznake, došlo je do neizbježnih nesuglasica po pitanju njihove klasifikacije i funkcija. Za potrebe ovog rada, u sljedećih ćemo se nekoliko odlomaka osvrnuti na tri najprominetnija pristupa diskursnim oznakama. Riječ je o funkcionalističkim pristupima zasnovanim na kriteriju koherentnosti (Schiffrin, Maschler, Redeker, Lenk), Fraserovu pristupu i teoriji relevantnosti Diane Blakemore.

Uz spomenute ćemo se autore također dotaknuti i znanstvenih doprinosa iz domaćeg i regionalnog jezikoslovlja vezanih za problematiku diskursnih oznaka. Tu svakako možemo ubrojiti autore poput Zrinjke Glovacki-Bernardi, Lade Badurine i Josipa Silića, no i mnoge druge neofilologe i lingviste koji su se dotakli ove teme.

\section{1. 1. Anglosaksonska tradicija}

Misao anglosaksonskih znanstvenika vezanu za područje diskursnih oznaka možemo smatrati pionirskom i za sada najplodonosnijom. Proučvanjem stvarne jezične upotrebe $u$ kontekstu, tj. otkrivanjem sociolingvističkih i pragmatičkih tema, američki su lingvisti svojim etnometodološkim studijama i izgradnjom prvih korpusa govorenog jezika prvi dotakli temu i ovih jezičnih jedinica. Labov i Fanshel ih spominju već 1977. godine u svome djelu Therapeutic Discourse, opisujući upotrebu engleskog izraza well. Nakon njih, 1983. Levinson ih se dotiče u svojoj poznatoj knjizi Pragmatics, objašnjavajući prirodu diskursnih oznaka na sljedeći način:

„[...] there are many words and phrases in English, and no doubt most languages, that indicate a relationship between utterance and the prior discourse. Examples are utterance-initial usage of but, therefore, in conclusion, to the contrary, still, however, anyway, well, besides, actually, all in all, so, after all and so on. It is generally conceded that such words have at least a component of meaning that resists trhuth-conditional treatment. What they seem to do is indicate, often in very complex ways, just 
how the utterance that contains them is a response to, or a continuation of, some portion of the prior discourse". (Levinson 1983: 87-88)

Dvije godine kasnije, Arnold Zwicky prvi puta imenuje tu vrstu izraza i naziva ih klitikama i česticama u naslovu svoje studije Clitics and Particles (1985). Ondje ih opisuje kao jezične univerzalije koje su mjesto pronašle u česticama iako zaslužuju biti autonomna gramatička kategorija na temelju svoje distribucije, prozodije, značenja i funkcija.

U to vrijeme, sredinom osamdesetih godina 20. stoljeća dolazi do prvih sustavnih istraživanja diskursnih oznaka i nastanka nekolicine relevantnih teorija koje će udariti temelje ovome području i utjecati na sva buduća istraživanja.

\subsubsection{Funkcionalizam Deborah Schiffrin}

Deborah Schiffrin renomirana je američka znanstvenica koja je svoje najpoznatije radove napisala iz šireg područja sociolingvistike i analize diskursa, te užeg područja diskursnih oznaka u engleskom jeziku. Autorica je nakon magisterija iz sociologije završila doktorat iz lingvistike pod mentorstvom Williama Labova, na sveučilištu u Pennsylvaniji, 1982. godine. Nakon toga predavala je na Sveučilištu Georgetown u Washingtonu DC-u i Sveučilištu Berekley u Kaliforniji. Njezin najvažniji rad zasigurno je rad na diskursnim oznakama koji je okrunila kapitalnim djelom u vidu pionirske monografije Discourse markers iz 1987. Time su dane osnove za njihovo sustavno proučavanje i potaknut je nastanak brojnih teorijskometodoloških pristupa ovoj jezičnoj pojavi. Spomenutim je djelom Schiffrin nastojala objasniti distribuciju i upotrebu diskursnih oznaka u razgovoru, pri čemu se prvenstveno koristila statističkom metodom analize varijance (ANOVA) i teorijskim okvirom interakcijske sociolingvistike. Tako koncipiranim istraživanjem autorica je stekla uvid u načine na koje diskursne oznake doprinose ostvarenju koherentnosti diskursa (Schiffrin 1987: 326). Također, zbog pomno odabranog prigodnog uzorka populacije razjasnila je kako određene sociolingvističke varijable utječu na jezično ponašanje. Naposljetku, ukazala je i na ključnu ulogu intonacije u govorenom jeziku na primjeru engleskog uzvika oh! koji je svrstala pod diskursne oznake.

Diskursna analiza Deborah Schiffrin može se okarakterizirati kao funkcionalistička jer u prvi plan stavlja svrhovitost jezične djelatnosti, a time i važnost konteksta i komunikacije onkraj apstrakcije jezičnog sustava. Na jednak, tj. funckionalistički način autorica pristupa 
problematici diskursnih oznaka, govoreći da bez obzira na njihovu formalnu različitost (npr. pripadnost različitim sintaktičkim kategorijama) one imaju sličnu funkciju (npr. kontekstualizacija iskaza).

Schiffrin diskursne oznake definira kao „sekvencijski ovisne jedinice govora” (Ibid. 31) te kao „neobavezne jedinice koje se javljaju u početnom položaju nekog iskaza kako bi uspostavile odnose u govoru i tekstu" (Maschler i Schiffrin 2015: 4). Ona ih svaća kao sredstva za ostvarenje diskursne koherencije koja se pak može ostvariti na pet različitih diskursnih razina: u strukturi razmjene, strukturi radnje, ideacijskoj razini, u participacijskom okviru i na informacijskoj razini. Drugim riječima, diskursne oznake mogu koordinirati razgovore, slijed i ilokucijsku snagu govornih činova, ukazivati na odnose među idejama (propozicijama), koordinirati stavove govornika (prema sugovorniku i diskursu) i korištenje znanja. Ovisno o tome što povezuju, autorica govori da DO-e mogu imati lokalni ili globalni učinak. Ako povezuju isključivo susjedne iskaze, imat će lokalni učinak, a ako je riječ o povezivanju diskursnih dijelova većih od iskaza, radit će se o globalnom učinku. Iz navedenog je vidljivo da Schiffrin koncipira diskurs kako na lingvistički, tako i na sociološki način. Također, za nju je koherentnost konačan proizvod zajedničkog truda sugovornika da integriraju znanje, značenje, govorenje i radnju, što čitavoj teoriji daje pragmatičku notu. ${ }^{12}$

U ovoj knjizi autorica otkriva nekoliko osnovnih obilježja kategorije diskursnih oznaka, ističući pri tome sljedeće: neovisne su od rečenične strukture, nemaju fiksnu poziciju u rečenici, no često se javljaju u inicijalnom položaju, ne čine jedinstvenu sintaktičku kategoriju, bez obzira na formalnu različitost imaju slične funkcije, imaju ulogu kontekstualizacije.

Gisela Redeker (1991) također se može svrstati u ovu funkcionalističku struju predvođenu radom Deborah Schiffrin. Redeker se naime slaže sa zaključcima i postavkama iznesenim u monografiji Discourse markers (Schiffrin 1987), no pruža vlastiti doprinos i poneke izmjene u teoriji. Autorica drži da je potrebno jasnije definirati diskursnu koherentnost, da je nužno što više otvoriti kategoriju diskursnih oznaka za sve vezivne izraze, no da je s druge strane potrebno suziti koncept diskursa smanjenjem broja njegovih razina.

$\mathrm{Na}$ posljetku, Uta Lenk (1998) temi diskursnih oznaka pristupila je posredstvom problematike diskursne koherentnosti u svojoj knjizi Markers of discourse coherence. Čitav je

\footnotetext{
${ }^{12}$ Takvo shvaćanje neizbježno podsjeća na Griceovu teoriju komunikacijskog djelovanja, točnije na princip kooperativnosti i pripadajuće mu maksime.
} 
rad pokušaj još jednog općeg pregleda kategorije diskursnih oznaka s naglaskom na funkciju povezivanja.

\subsubsection{Teorija Brucea Frasera}

Fraserovo polazište i čitav pristup problematici diskursnih oznaka temelji se na razdvajanju semantičkog od pragmatičkog značenja ${ }^{13}$, tj. kako navodi Nigoević (2010: 21) kod njega se sve odvija „u okviru gramatičko-pragmatičke perspektive”. Autor ovdje ističe kako je semantičko značenje propozicijsko (i time podložno testiranju na istinitosne uvjete), dok je pragmatičko značenje interpretativno (odnosi se na govornikovu komunikacijsku namjeru i ne utječe na istinitost iskaza). Pragmatičkim oznakama, kako ih naziva Fraser (1990), svojstveno je pragmatičko značenje. On pragmatičke oznake nadalje dijeli na četri potkategorije: osnovne pragmatičke oznake (signali ilokucijske snage), komentare (na osnovnu poruku) i paralelne/istovremene pragmatičke oznake (iskazivanje stava prema sugovorniku ili situaciji). Svemu tome Fraser pridružuje i četvrtu kategoriju tzv. metakomentara na diskursnu strukturu.

Ukratko, prema ovome autoru osnovni bi cilj diskursnih oznaka bio signalizirati specifičnu, proceduralnu poruku, imajući na umu prethodni diskurs pri interpretaciji komunikacijske namjere.

Čitajući Frasera, nije na odmet imati na umu da u ranijim radovima autor diskursne oznake svrstava u potkategoriju pragmatičkih oznaka, posebice komentara. Nešto kasnije dijeli ih na četiri skupine: oznake promjene teme (by the way, speaking of), kontrastivne oznake (anyway, but, on the contrary), oznake elaboracije (above all, in other words, in fact) i inferencijalne oznake (after all, of course, so) (Fraser 1996). Kao zajednička obilježja svih diskursnih oznaka autor izdvaja sintaktičku heterogenost kategorije i njihov učestali inicijalni položaj unutar iskaza.

Autor također razlikuje oznake tipične za pisani diskurs od onih u govorenom diskursu, kao i oznake karakteristične za formalni, tj. neformalni stil. ${ }^{14}$ Osim toga on tvrdi kako je njihovo

\footnotetext{
${ }^{13} \mathrm{O}$ problematici značenja diskursnih oznaka više će se raspravljati u poglavlju 5.

${ }^{14}$ Takvo se razlikovanje tipičnih i atipičnih diskursnih oznaka očituje i u cyber-komunikaciji, posebno zbog tzv. „oralizacije pisanog teksta“(Yus 2011).
} 
značenje proceduralno, a ne konceptualno, tj. da nam one govore kako interpretirati neku poruku, a ne što je njezin propozicijski sadržaj.

Konačno, Fraser je u suautorstvu s Monicom Malamud-Makowski (1996) napisao jednu od prvih kontrastivnih studija diskursnih oznaka dvaju različitih jezika (engleskog i španjolskog).

\subsubsection{Teorija relevantnosti i Diane Blakemore}

Teorija relevantnosti (engl. Relevance Theory) kognitivno je pragmatička teorija Dana Sperbera i Deirdre Wilson (prvi puta objavljena 1986., prošireno izdanje izašlo je 1995.). Teorija je bazirana na procesima zaključivanja i definiciji relevantnosti uz pomoć dva osnovna principa relevantnosti: kognitivnog i komunikativnog principa. Ova je teorija ujedno i pokušaj razrađivanja dviju Griceovih postavki, tj. njegove teorije implikatura na kojoj se i sama temelji. Postavke su sljedeće: 1. osnovno je obilježje ljudske komunikacije iskazivanje i prepoznavanje namjera, 2. iskazi stvaraju očekivanja koja slušatelja navode prema govornikovu značenju. Iz navedenog je vidljivo da je ovaj komunikacijski model (kao i onaj Griceov) utemeljen na procesima zaključivanja (inferencijalni model) umjesto na kodu kao klasični modeli, a osnovni cilj inferencijalne pragmatike bio bi objasniti kako slušatelj zaključuje o govornikovu značenju na temelju dobivenih dokaza iz šireg komunikacijskog konteksta. Upravo zbog inferencijalne prirode ovog modela ne iznenađuje činjenica da su se diskursne oznake početkom dvijetisućitih počele istraživati unutar njega, a ne u sklopu kodom određenog teorijskog okvira.

Jedna je od temeljnih tvrdnji teoretičara relevantnosti ta da su očekivanja relevantnosti (pobuđena iskazom) dovoljno precizna i predvidljiva za donošenje zaključaka o namjeravanom značenju. Drugim rječima, ovi autori smatraju da nam za to nije potreban Griceov princip kooperativnosti ni sve njegove maksime ${ }^{15}$, već sve maksime svode na maksimu relevantnosti, na koju više ne gledaju kao Grice. Ta se maksima sada počinje percipirati kao kognitivni princip, a ne kao sociokulturna norma. Time se gubi sociokulturni i interakcijski moment, a potenciraju se isključivo kognitivni aspekti komunikacije. Danas se posredstvom novih tehnologija i razvoja cyber-komunikacije pokazala upitnost takvih stavova, a sama maksima

\footnotetext{
${ }^{15}$ Detaljnije o osnovama teorije implikatura H.P. Gricea vidi u poglavlju 3.2.
} 
relevatnosti kao okosnica uspješne komunikacije pokazala se u najmanju ruku problematičnom (Herring 2001).

Autorima se također može prigovoriti da ovdje uvode i nekoliko vrlo intuitivno jasnih i logičnih tvrdnji vezanih za relevantnost i spoznaju, no oblače ih u novo terminološko ruho. Tako se primjerice spominje tzv. pozitivni kognitivni učinak koji stvara relevantnost (tj. učinak koji čini razliku u pojedinčevoj reprezentaciji svijeta kao relevantan) i odnos kognitivnog napora i relevantnosti kao obrnuto proporcionalnog (tj. što je nešto relevantnije, u procesiranje će biti potrebno uložiti manji kognitivni napor i obratno).

Nadalje, kako za Gricea tako i za teoretičare relevantnosti bitna je teorija uma (engl. Theory of Mind). Ona govori da reprezentacija svakog iskaza uključuje visok stupanj metareprezentacijskih sposobnosti, jer razumijevanje počiva na sposobnosti pripisivanja kako informativnih, tako i komunikacijskih namjera drugome. S obzirom na to da se pragmatička interpretacija smatra spontanom i intuitivnom, a ne svjesnom, reflektivnom i modularnom, još jednom možemo ponoviti da ne čudi što će pragmatičkim jedinicama poput diskursnih oznaka više odgovarati inferencijalni i funckionalni, a ne formalni teorijski okvir.

Kao učenica Deirdre Wilson, Diane Blakemore (2004) proučvala je diskursne oznake u okviru teorije relevatnosti. Nazivajući ih nešto drugačijim imenom, diskursnim veznicima (engl. discourse connectives), Blakemore tvrdi da su to izrazi koji se upotrebljavaju za isticanje relevatnosti jednog dijela diskursa u svrhu interpretacije nekog drugog dijela diskursa. Također, ona ističe da diskursni konektori mogu poslužiti i za aktiviranje određenih konteksta. Za razliku od prethodnih autora, Blakemore ovdje ne razmatra diskursnu koherentnost u odnosu na diskursne oznake, već ih shvaća kao sredstva koja doprinose kognitivnoj interpretaciji i procesiranju iskaza.

Autorica se u vlastitom radu na diskursnim oznakama dosta posvetila problematici njihova značenja, zbog čega su joj kasnije bile upućene brojne kritike i došlo je do manjih revizija njezine teorije. Naime Balkemore smatra da razlikovanje istinitosno od neistinitosno uvjetovanog značenja u logičko-filozofskoj tradiciji u lingvistici treba ustupiti mjesto opreci između konceptualnog i proceduralnog značenja, tj. pragmatičkoj razlici između implicitnog i eksplicitnog. Nadalje, Blakemore diskursne veznike tretira kao Griceove konvencionalne implikature koje usmjeravaju i omeđuju proces zaključivanja, te sama upućuje veliku kritiku autorima koji proučvaju diskursne oznake iz perspektive diskursne koherentnosti. Po mišljenju autorice, kao i prema čitavoj teoriji relevatnosti, razumijevanje diskursa nije nusproizvod 
koherentnosti, već je diskursna koherentnost posljedica postizanja relevantnosti. Upravo zato Blakemore drži da pristupi isključivo bazirani na konceptu diskursne koherentnosti u vidu strukturalnih odnosa neke cjeline u obzir ne uzimaju osnovne elemente ljudske komunikacije: namjeru, tumačenje i interpretaciju iskaza. Prema riječima Magdalene Nigoević (2010: 33), za Blakemore diskursne oznake nisu samo izrazi koji povezuju dijelove diskursa, već ih je potrebno promatrati u sklopu teorije relevantnosti, tako da se više pažnje prida kognitivnim procesima razumijevanja diskursa te da se analizira DO-e kao kontekstualizirajuće elemente.

Kao što je prethodno spomenuto, teorija autorice Blakemore doživjela je i neke kritike, ponajviše one vezane za problematiku značenja diskursnih oznaka. Portolés (1998) i Murillo (2000) između ostalih ističu da pri razlikovanju jedinica s konceptualnim i proceduralnim značenjem treba biti oprezan iz nekoliko razloga, ponajviše (dijakronijski gledano) zbog činjenice da se svaka diskursna oznaka razvila od riječi ili izraza iz neke druge jezične kategorije koja je bila punoznačna. Tragovi konceptualnog značenja te riječi koja je prethodila nastanku diskursne oznake mogu još biti prisutni, stoga uz proceduralno značenje obično imamo i osnovu konceptualnog. ${ }^{16}$

\subsubsection{Ostali autori}

Uz navedena imena ovog područja istraživanja u anglosaksonskoj tradiciji, zaigurno vrijedi spomenuti i Kerstin Fischer, urednicu zbornika radova Approaches to discourse particles (2006) koja nudi svoju pristup diskursnim oznakama i problematizira terminološku prikladnost te sinkronijski presijek kategorije.

Nadalje, Karin Aijmer i Anne-Marie Simon-Vandenbergen (2006) autorice su još jednog zbornika radova pod nazivom Pragmatic Markers in Contrast. Kao i u prethodnome zborniku, i ovdje se težište stavlja na probelmatičnost terminologije, ipak urednice dozvoljavaju više slobode i time donose korisne taksonomije područja.

Na posljetku, Andreas H. Jucker i Yael Ziv (1998: 3) doprinose svojim sažetim popisom obilježja diskursnih oznaka u vidu njihovih: fonoloških i leksičkih obilježja, sintaktičkih obilježja, funkcionalnih i sociolingvističkih karakteristika.

\footnotetext{
${ }^{16}$ Više o problematici značenja diskursnih oznaka u poglavlju 5.
} 


\subsubsection{Domaće i regionalno jezikoslovlje i slučaj diskursnih oznaka}

S pojavom tzv. pragmatičkog zaokreta u lingvistici sedamdesetih godina prošlog stoljeća, tj. jačanjem interesa za uporabnu, komunikacijsku stranu jezika, dolazi do buđenja interesa za razinu diskursa i kod naših znanstvenika. Ovdje ponajprije mislimo na Josipa Silića, zatim na tekstne lingviste poput Mirne Velčić i Zrinjke Glovacki-Bernardi, analitičare diskursa kao što su Lada Badurina i Magdalena Nigoević, te pragmatičare poput Nede Pintarić (konverzacijska analiza) i Nade Ivanetić (teorija govornih činova).

Navedeni autori (iako ne jedini), kao i njihovi strani kolege, uočili su problematičnost definiranja kategorije u pitanju. Povrh svega i ovdje se pojavio problem s terminologijom. Stoga se u hrvatskoj literaturi umjesto diskursne oznake obično upotrebljava termin čestica, ali i drugi nazivi poput: površinske zamjenice dubinskih rečenica (Tekavčić 1982), signali kontekstualne uključenosti rečenice (Silić 1984), konektori (Velčić 1987), partikule na modalnoj razini (Sesar 1992), riječice, čestice i diskursne oznake (Badurina 2008, Nigoević 2010).

\subsubsection{Josip Silić - od sintakse prema diskursu}

Knjiga Josipa Silića iz 1984. godine pod nazivom Od rečenice do teksta. Teoretskometodološke postavke nadrečeničnog jedinstva može se smatrati pionirskim radom u hrvatskom jezikoslovlju iz područja diskursne i tekstne analize. Autor se prvi na našem području sustavno počeo interesirati za jezičnu razinu koja nadilazi razinu rečenice, no to je činio prvenstveno iz perspektive sintaktičara, što iznimno dobro oslikava sljedeći citat:

„Rečenica kao jedinica govora dobiva svoj puni smisao u nadrečeničnom jedinstvu (složenom sintaktičkom jedinstvu, složenoj sintaktičkoj cjelini, proznoj strofi, komponenti teksta, diskursu i td.) kao najvišoj i najsloženijoj razini sintakse. U njemu je ona združena s drugom rečenicom te zajedno $s$ njome čini strukturno, smisaono, ritmo-melodijsko i stilističko jedinstvo.“"(Silić 1984: 7)

Unatoč sintaktičkom nasljeđu, Silić se uspijeva osloboditi okvira rečenice i time pružiti poticaj za rad jezikoslovcima koji će na akademsku scenu stupiti nešto kasnije. 
Autor se u ovome radu ponajprije bavi semantičko-gramatičkim poretkom riječi koji određuje ko(n)tekst, stilistikom s obzirom na dinamičnost komunikacije, jezičnom ekonomijom i (nama najrelevantnijim) tzv. signalima kontekstualne uključenosti rečenice. Upravo su ti „signali“ shvaćeni kao elementi koji kontekstualiziranu rečenicu (tj. iskaz) razlikuju od rečenice kao apstraktne gramatičke jedinice. Silić spomenute signale naziva konektorima i definira ih kao sredstva koja iskaze povezuju u cjeloviti tekst. On nam također pruža njihovu tipologiju, dijeleći ih na gramatičke, leksičko-gramatičke, leksičke i stilističke konektore. Osim prve skupine gramatičkih konektora u koju ubraja tzv. nezavisne ili kooridninacijske veznike $(i, p a$, $a, n i$, ali, nego, no, ili), sve ostale skupine autor dalje raščlanjuje na iznimno detaljizirane potpodjele koje jesu smislene, no u teoriju i analizu unose dodatnu kompleksnost. Ovdje svakako nećemo proći čitavom tipologijom, no istaknut ćemo nekoliko relevantnih Silićevih spoznaja koje se nadovezuju na problematiku ovog rada.

Prije svega, vrlo je zanimljiva podvrsta tzv. propozicionalnih konektora koji se obično javljaju na diskursnim granicama i predstavljaju međutekstne veze i strukturu diskursa. Tu se zapravo radi o konektorima koji upućuju pažnju publike na prethodni ili nadolazeći tekst (npr. kao što smo prethodno ukazali, promotrimo sada), ali sami ne nose nikakve nove informacije. Nadalje, autor je posebnu pažnju posvetio početnim i završnim rečenicama nekog iskaza, ukazavši na konektore koji su karakteristični kako za jedne tako i za druge tipove iskaza. Također je uveo razlikovanje između linearnog i paralelnog načina povezivanja rečenica $u$ diskurs, pri čemu se u prvom obliku povezivanja rečenice nižu, dok paralelnim povezivanjem formiraju diskurs pozivanjem na opću tematiku diskursa u pitanju. Drugim riječima, povezivanje rečenica u nadrečeničnu razinu može imati dva osnovna pravca: odozdo prema gore (linearno, sintagmatski, in praesentia, od dijelova prema cjelini) i odozgo prema dolje (paralelno, paradigmatski, in absentia, od cjeline prema djelovima).

Naposljetku, neizostavno je spomenuti Silićevo polazište kada promišlja tekst, jer se ono zasniva na vrlo bitnoj distinkciji: razlikovanju gramatike kao modela od komunikacije kao ostvarenja tog modela. Na to se nadovezuje i razlikovanje apstraktnog značenja u sustavu od kontekstualiziranog smisla iskaza, tj. razlika između gramatike i pragmatike, što sam autor ne spominje, nastojeći zadržati svoj rad u okvirima sintakse i stilistike. 


\subsubsection{Tekstna lingvistika - Velčić $\boldsymbol{i}$ Glovacki-Bernardi}

Mirna Velčić krajem osamdesetih godina prošlog stoljeća, nekoliko godina nakon prethodno spomenute Silićeve knjige, objavila je vlastitu knjigu pod nazivom Uvod u lingvistiku teksta (1987). Ondje se autorica pozabavila načinima povezivanja u pisanoj i govorenoj komunikaciji. Indikativno iz naslova knjige, ovoj se problematici pristupilo iz perspektive tekstne lingvistike, pri čemu Velčić velik naglasak stavlja na metodu, za koju tvrdi da treba biti oslobođena ograničenja koja nameće gramatika, pa čak i funkcionalni gramatički pristupi jer su preuski i nedostatni. Autorica ovdje uočava i ističe da takvi pristupi ne mogu objasniti sintaktičku heterogenost kategorije konektora (kako sama naziva diskursne oznake) kao ni činjenicu da osnovno polazište tekstne analize treba biti tekst a ne rečenica, jer se u tekstu ocrtavaju kriteriji za rečenično povezivanje.

Nadalje, intrigantan je autoričin pristup podjeli konektora u potskupine, pri čemu se podjela temelji na dvama osnovnim kriterijima: kriteriju funkcionalnosti (tj. ovisno o tome koju funkciju neki konektor obnaša, u tu će skupinu spasti - npr. konektori zaključivanja i konektori suprotnosti) te kriteriju svojevrsnog dijakronijskog razvoja. Prvi kriterij, tj. funkcionalni kriterij nije novost, no ono što njime dobivamo jest kategorija otvorenog popisa jedinica, stoga ne bi bilo loše da su se funkcionalnom pridodali još neki kriteriji.

Naposljetku, pohvalno je što je autorica ukazala na važnost dijakronijske dimenzije i promjena do kojih može doći na tekstnoj razini tj. razini diskursa, ipak ne bismo se složili s njezinom drugom podjelom konektora na pet kategorija, navođenom pravcem razvoja konektora od gramatikalizacije prema leksikalizaciji. Naime, njihov razvojni put može se pratiti kroz prilagođeno shvaćanje klasične gramatikalizacije ili sličnog procesa (Heine 2013) na razini diskursa, no određeni kriteriji u klasičnom smislu gramatikalizacije ovdje ne bivaju zadovoljenima. Također, kod ovakve tvrdnje nameće se pitanje je li leksikalizacija proces prema kojem se kreće gramatikalizacija ili ne? Drugim rječima, koji su mogući ishodi procesa gramatikalizacije diskursnih funkcija? O toj problematici bit će više riječi u poglavlju 5 . Također, iako je autorica naglasila da se treba odmaknuti od rečenične razine, u njezinoj se podjeli vidi dominacija sintakse. Tako npr. imamo relativne (što, tko, koji, kakav), vezničke ( $i$, ali, jer) i priložne konektore (međutim, naime, naprotiv), čije kategorije u osnovi predstavljaju 
kategorije nepromjenjivih vrsta riječi hrvatske gramatike. Ono što je inovativno jest činjenica da Velčić ističe kako je bitnije otkriti zašto neki izraz postaje konektorom, dok nije toliko relevantno što on znači i kako ga definirati (1987: 116). Do tih se spoznaja, posebice onih dijakronijske prirode, nastoji doprijeti i danas.

Glovacki-Bernardi svoju knjigu o tekstnoj lingvistici $O$ tekstu objavljuje 1990. godine, svega nekoliko godina nakon Velčić, čime se nastavlja pobuđeni interes za tekstnu razinu jezika u lingvistici naših prostora.

Autoričino polazište obilježeno je tradicionalnim strukturalističkim nasljeđem koje se ogleda u njezinom interesu za pojam odnosa među jezičnim elementima. Tu je naglasak stavljen ponajviše na foričke odnose kao jednom od sredstava kojima se ostvaruje tekstna koherentnost i smislenost teksta kao cjeline. Parafrazirajući Glovacki-Bernardi, možemo reći da su upravo odnosi između jezičnih elemenata temeljna pretpostavka jezika shvaćenog kao ustrojstvo, kao sustav, stoga se određena jezična cjelina može smatrati tekstom samo ako se konstitutivni elementi i cjeline pojavljuju povezani te ako je ta povezanost i značenjski smislena.

S druge strane, autorica se oslanja na funkcionalne i filozofsko-pragmatičke pristupe jeziku (npr. teoriju govornih činova), ističući važnost proučavanja jezične upotrebe, komunikacijskih funkcija jezika i intencionalnosti ${ }^{17}$. S obzirom na funkcije koje neke riječi obnašaju, GlovackiBernardi ih je podijelila u dvije osnovne kategorije: logičko-gramatičke (npr. broj, tj. jednina/množina imenice) i komunikacijsko-gramatičke (npr. lice glagola). Tome kasnije pridodaje treću, čistu pragmatičku kategoriju (iako ju tako ne imenuje) govoreći da u nju spadaju izrazi koji omogućuju funkcioniranje jezika (npr. deikse, čestice i sl.)

Od svih funkcionalnih jezičnih kategorija koje autorica spominje nama je najrelevantnija i najzanimljivija kategorija partikula, tj. čestica. Naime, ovdje se ukazuje na to da se upravo na mjestima povezivanja rečenica mogu pojaviti čestice, te da im je osnovna funkcija signalizirati primatelju poruke tzv. argumentativne i situacijske odnose u tekstu. Drugim riječima, čestice bi zapravo bile diskursne oznake.

Također, Glovacki-Bernardi osvrće se na probleme definiranja čestica u tradicionalnim gramatikama. Ona ističe kako su partikule gotovo izmaknule takvim opisima jer je fokus tih

\footnotetext{
${ }^{17}$ Pojam intencionalnosti, tj. intencije u ovom će radu biti shvaćen u užem smislu (kako ga vidi H. P. Grice), kao sastavni dio govornikova značenja koji treba biti prepoznat i interpretiran od strane slušatelja, ne bi li se ostvarila uspješna komunikacija.
} 
gramatika stavljen na razinu rečenice koja se nije prelazila. Za razliku od klasičnih sinatktičkih opisa i kategorija, čestice su funkcionalna kategorija diskursne razine, uporabne razine, karakteristične za govorenu komunikaciju te ne čudi da ih autori koji su polazili iz tradicionalno gramatičkih perspektiva nisu mogli dokučiti. Naposljetku, autorica ovdje upućuje kritiku znanstvenicima koji su taj problem nastojali riješiti uvođenjem posebne kategorije modalnih riječi. Prema njezinoj argumentaciji, pojam modalnosti danas je višeznačan, tj. određuje svojstva nekih glagola, stoga nije dovoljno precizan, jasan ni prikladan.

Autorica zaključuje kako su osnovne funkcije čestica usmjeravanje komunikacije, otkrivanje govornikova značenja i intencije te kontekstualizacija s ciljem što točnije interpretacije iskaza. Naposljetku, ukazuje i na potrebu za formiranjem svojevrsne transfrastičke gramatike u budućnosti (Glovacki-Bernardi 1990: 51).

\subsubsection{Diskurs $i$ suvremeni hrvatski jezik - Lada Badurina i ostali}

Lada Badurina riječka je kroatistica koja je velik dio svog znanstvenog rada posvetila proučavanju razine hrvatskog diskursa, pa tako i diskursnih oznaka. 2008. godine izdala je knjigu Između redaka. Studije o tekstu i diskursu, kojom je pružila pregled teorija i najvažnijih teza diskursnih pristupa. Također, istaknula je nužnost i relevantnost analize nadrečenične razine, tj. analize iskaza u kontekstu nasuprot tradicionalnim gramatičkim pristupima baziranim na dekontekstualiziranim rečenicama i razini sintakse. Drugim rječima, autorica je ukazala na značaj pragmatike pri svakoj jezičnoj analizi i prva je problematizirala sam pojam diskursnih oznaka u kroatističkoj literaturi. Diskursne je oznake definirala na nešto širi način, kao kategoriju jezičnih činjenica koje djeluju u spoznajnoj, ekspresivnoj, društvenoj i tekstualnoj domeni (Badurina 2008: 96), te kao elemente koji sjedinjuju iskaze unutar diskursa.

Ono što se ističe kod Badurine i njezinog rada na diskursu općenito i diskursnim oznakama specifično, jest činjenica da je autorica uočila teorijsko-terminološku i metodološku raznovrsnost pristupa diskursnim oznakama kao i potrebu za nekim novim perspektivama.

Uz Badurinu bismo svakako spomenuli i Magdalenu Nigoević, koja je problematici diskursnih oznaka pristupila na nešto drugačiji način: iz kontrastivnog aspekta, uspoređujući slučaj talijanskih i hrvatskih diskursnih oznaka (2010). Pri tome je autorica također pružila 
osnovni pregled strane i domaće literature na spomenutu problematiku, pozabavila se terminologijom, obilježjima, klasifikacijom i funkcijama DO-a.

Osim kontrastivnih pristupa, autori su diskursnim oznakama pristupali i sa stajališta pragmatike i sociolingvistike (Pintarić 2002; Dedaić Nelson 2005). U sklopu spomenutih područja znanstvenog interesa svakako bismo istaknuli nekoliko radova o poštapalicama. Naime, određeni autori smatraju ih specifičnom vrstom diskursnih oznaka (Badurina i Matešić 2007; Zovko 1999), dok ih Hrvoja Heffer definira kao govorne signale koji su:

„... vremenski dobitak, glasna stanka, izgovorena bjelina koja govorniku pomaže popuniti govorne praznine ili jednostavno odugovlačiti, oklijevati ne bi li našao prave riječi koje bi nastavile započetu mu misao ili koje u danome trenutku ne bi povrijedile sugovornika ili širu javnost“. (1999: 298)

Je li zaista riječ o posebnoj podvrsti diskursnih oznaka, prodiskutirat ćemo nešto kasnije (poglavlje 5 i 6).

\subsubsection{Regija - diskursne oznake u južnoslavenskim jezicima}

U serbistici diskursne oznake, tj. diskursni markeri (kako ih srpski kolege najčešće nazivaju) nisu novost kao tema, no njihovo značajnije proučavanje započinje krajem prve dekade 21 . stoljeća. I u ovoj su tradiciji pristupi temi iznimno raznovrsni, a neki od autora koje bismo spomenuli bili bi sljedeći: Ksenija Končarević (2007), Ljudimila Popović (2009), Strahinja Stepanov (2010), Milica Vuković (2010), Nevena Ceković-Rakonjac (2011), Biljana Mišić-Ilić i Vesna Lopičić (2011), Natalija M. Panić (2012) i brojni drugi. Što se pak bosanistike tiče, nešto je slabija produkcija radova na ovu temu, no treba spomenuti autore poput Bernesa Aljukića i Emine Kurtić (2013), Minke Džanko (2010) i Belkise Dolić (2016).

Govoreći o radovima vezanim za problematiku diskursa i diskursnih oznaka, na području južnoslavistike, potrebno je istaknuti zbornik radova South Slavic Discurse Particles koji je izašao 2010. godine, a uredile su ga Mirjana Dedaić Nelson i Mirjana Mišković-Luković. Zbornik donosi šest studija o česticama iz šest različitih južnoslavenskih jezika (bugarski, makedonski, srpski, bosanski, hrvatski, slovenski), no sami autori studija ni ovdje nisu jednoglasni po pitanju terminologije vlastitog predmeta istraživanja. Stoga neki proučavaju diskursne oznake, neki diskursne markere, drugi konektore, treći modifikatore, četvrti 
poštapalice, a peti čestice. Ipak, pri njihovu opisu, funkcijama i definicijama vidljive su brojne zajedničke točke i velika preklapanja. Svi autori na jedinice koje problematiziraju gledaju kao na svojevrsna vezivna sredstva diskursne razine, često im pristupaju iz perspektive teorije relevatnosti, sinkronijski su orjentirani i temelje vlastite zaključke na analizama stvarne jezične upotrebe.

\subsubsection{Teorijsko-metodološki brikolaž}

S ciljem daljnjeg proučavanja fenomena diskursnih oznaka, posebice u sklopu komunikacije novim medijima, nametnuo se neizbježni teorijski i metodološki brikolaž koji će se ocrtavati čitavim ovim radom. Naime, svi spomenuti autori i njihovi pristupi diskursnim oznakama pružili su nam ponešto i omogućili dobre temelje za daljnju razradu problema. Ipak, određeni dijelovi tih istih teorija nisu se pokazali adekvatnima, bilo zbog drugačijih disciplinarnih polazišta, bilo zbog novih znanstvenih spoznaja kao i promjene konteksta istraživanja ili pak zbog konkretnih ciljeva rada.

Nadovezujući se i gradeći na tradiciji kako stranih tako i domaćih autora, ono što će biti uklopljeno i u našu teoriju i metodu jesu sljedeća obilježja: isticanje značaja jezične funkcionalnosti, pristupanje problemu (DO-a i cyber-komunikacije) s razine diskursa i pragmatike, ukazivanje na potrebu za transfrastičkim pristupima jeziku, uvažavanje relevantnosti konteksta za interpretaciju i analizu iskaza i stjecanje alata za promatranje dijakronijskih promjena na diskursnoj razini.

Samim time možemo ustvrditi da su se za našu problematiku iznimno korisnima pokazala Silićeva promišljanja teksta zasnovana na razlikovanju gramatike od pragmatike koja nas (s vremenom) dovode do ideje o funkcionalnim gramatikama, gramatikama nadrečenične razine. Također, sam naziv diskursnih oznaka kao „signala kontekstualne uključenosti rečenice“ mnogo nam je rekao o značaju ovih jedinica za postizanje diskursne kohezivnosti i koherentnosti. Jednako tako, tim je terminom Silić ukazao na relevantnost konteksta pri jezičnoj upotrebi, što itekako dolazi do izražaja u slučaju cyber-komunikacije lišene zajedničkog fizičkog konteksta, tj. u kojoj suprisutnost biva zamijenjena teleprisutnošću. Uz Silićev sintaktički pristup fenomenu DO-a, Velčić nam prva donosi tekstno lingvistički. Ono što se u pristupu ove autorice pokazalo iznimno korisnim i (gotovo) ispred svoga vremena, dvije su osnovne stvari. Prva je uvođenje funkcionalnih kriterija za određenje kategorije diskursnih 
oznaka, dok je druga ukazivanje na važnost (i postojanje) dijakronijskih procesa na razini diskursa. Za razliku od Velčić, mi se u vlastitoj teoriji i metodi nismo fokusirali na tekst kao osnovnu jedinicu, već na diskurs i govorni čin, što je u suvremeno doba najbolje ocrtano modelom funkcionalne diskursne gramatike (FDG). ${ }^{18}$ Također, na nešto drugačiji način gledamo na proces gramatikalizacije diskursnih funkcija koji prema našim spoznajama ne vodi nužno k leksikalizaciji. ${ }^{19}$ Jednako kao i Velčić, Glovacki-Bernardi svoje temelje gradi na tekstnoj lingvistici, no autorica težište stavlja na dva kriterija tekstualnosti: kohezivnost i koherentnost kojima pristupa proučavanjem foričkih odnosa. Vrlo slično kao Schiffrin, Glovacki-Bernardi ističe jezičnu upotrebu i funkcionalnost kao i potrebu za transfrastičkim gramatikama, s čime se slažemo. Ipak, smatramo da je čitavom pristupu potrebno osvježenje, posebice u terminološkom smislu jer upotreba termina čestica ili partikula za elemente kao što su diskursne oznake pokazala se višeznačnom i time neadekvatnom. Naposljetku, pristup Lade Badurine pokazao je svoju korisnost jer je autorica među prvima eksplicitno ukazala na značaj pragmatike i diskursne analize. Također, dotakla se problema tradicionalnih gramatika kojima iz domene izmiču diskursne jedinice, no nažalost nije ponudila suvremeni gramatički model koji bi se mogao nositi s pragmatičkim fenomenima. Kao što će kasnije biti prikazano, potencijal za tako nešto mi vidimo u modelu funkcionalne diskursne gramatike (poglavlje 3.5.).

Specifičnosti cyber-diskursa (poput teleprisutnosti, heterosemiotičnosti i identitetskih jezičnih igara) ne samo da nam mogu pružiti nov kut gledišta na jezične probleme, već to i čine. Upravo iz tog razloga stvara se nužnost za osmišljanjem metode i teorijskog okvira za njegovu analizu, što nas dovodi do ovakvog teorijsko-metodološkog brikolaža.

\footnotetext{
${ }^{18}$ Pogledaj poglavlje 3.5 .

${ }^{19}$ Više o problemu gramatikalizacije diskursnih funkcija u poglavlju 5.
} 


\section{2. Novom perspektivom kroz stare probleme (ciljevi i svrha istraživanja)}

Osnovni su ciljevi rada:

- razjasniti kriterije za određenje kategorije diskursnih oznaka

- naglasiti zamke epistemoloških problema struke (problem zanemarivanja jezične upotrebe u korist apstraktnog jezičnog sistema)

- ukazati na dijakronijske (evolutivne) procese što se odvijaju na razini diskursa

- istaknuti potrebu za funkcionalnim pristupima jeziku i važnost širenja tradicionalnog viđenja gramatike.

\subsubsection{Potreba za jasnim razgraničenjem kategorije diskursnih oznaka}

Iščitavajući prethodna istraživanja naše problematike, susreli smo se s nekoliko problema i ograničenja koja se opetovano ponavljaju. Ti bi problemi prije svega bili problemi postizanja konsezusa unutar struke o nazivlju kategorije (terminološki problemi). Raspravom u ovom radu nastojat će se ponuditi nekoliko najuvjerljivijih terminoloških opcija, posebice za područje hrvatskog jezikoslovlja.

Drugi veliki problem odnosi se na određivanje kriterija kategorije diskursnih oznaka. Drugim rječima, koje kriterije postaviti kao uvjete koji moraju biti zadovoljeni ne bi li nešto bilo diskursnom oznakom? Koliko takvih kriterija uvesti ne bi li ograničili kategoriju? Može li se kategorija jezičnih izraza ovog tipa uopće ograničiti kao skup ili joj je obilježje otvorenosti jedna od dominantnih karakteristika? Na sva navedena pitanja pokušat ćemo odgovoriti u poglavlju 4.

Naposljetku, javlja se i zadatak definiranja kategorije koji pak seže u problematiku razgraničenja gramatike od pragmatike, odnosno vodi nas prema određenjivanju razine na kojoj kategorija diskursnih oznaka funkcionira. Ovdje se nameću pitanja utjecaja pragmatike na gramatiku, tj. isprepletenosti razina kao i nužnosti uvođenja diskursne razine u jezične opise. Najviše riječi o tome bit će u podnaslovu „Cyber-pragmatika” koji slijedi. 


\subsubsection{Zamke epistemoloških problema struke}

Prethodni problem vezan za odnos gramatika/pragmatika, ali i pragmatika/semantika, doveo nas je do još jednog cilja ovog rada. Taj cilj nikako nije razriješiti stoljetnu raspravu o osnovnim lingvističkim disciplinama, njihovom međusobnom utjecaju i problemu jezične upotrebe koja se sa strukturalizmom odvojila od domene čistog jezikoslovlja. Cilj bi bio nešto umjereniji, bio bi barem ukazati na relevantnost pragmatičke, tj. diskursne razine i funkcionalno nastrojenih pristupa jeziku, kako za sve jezične razine, tako i za jezično usvajanje čak i problematiku jezične evolucije.

\subsubsection{Značaj dijakronijskog pristupa diskursu}

Uz sam sinkronijski presijek kategorije, smatramo da proučavanje razvoja diskursnih oznaka može uvelike doprinijeti njihovoj kategorizaciji i boljem shvaćanju čitave kategorije. To ćemo nastojati prikazati primjerima iz analiziranih korpusa, no vjerujemo da će dijakronijski pristup biti iznimno koristan pri određenju parajezičnih fenomena koji se često dovode u vezu s diskursnim oznakama: kategorije poštapalica i kategorije dijalogične šutnje. Vidjet ćemo da su poštapalice često smatrane potkategorijom diskursnih oznaka, s čime se ne slažemo, već smatramo da su povezane s diskursnim oznakama na osi evolucije. Također, raspravljat ćemo o fenomenu zabilježene šutnje u sklopu dijaloga na mreži. Ondje će se propitati povezanost šutnje kao parajezične kategorije s kategorijom diskursnih oznaka u funkciji tzv. ograda (hedges), ali i u funkciji iskazivanja emocija i stavova. Postavit će se pitanje: može li zabilježena, dijaloška šutnja biti diskursna oznaka? Potječu li neke diskursne oznake iz dijaloške šutnje ili takva šutnja predstavlja inačicu (potkategoriju) diskursne oznake? 


\subsubsection{Potreba za funkcionalističkim teorijama jezika}

Teorijsko-metodološki pristupi korišteni za potrebe ovog rada, poput konverzacijske analize, analize diskursa i pragmatike, nalažu potrebu za postavljanjem objedinjujućeg modela jezika, odnosno svojevrsne transfrastičke gramatike. Stoga, ukoliko se u cjelokupnoj jezičnoj analizi u obzir uzima i diskursna razina, taj model zahtijeva kako formalno tako i funkcionalističko gledište na jezik te uvažavanje interdisciplinarnosti.

Jedan je od uvjerljivijih modela tog tipa u posljednje vrijeme tzv. funkcionalna diskursna gramatika, tj. FDG (Hengeveld i MacKenzie 2008), čija je osnovna jedinica analize diskursni čin te koja sintaktički, morfološki i fonološki kodirane jezične fenomene vidi kao povezane s pragmatičkim i semantičkim aspektima formulacije. FDG funkcionalne pristupe jeziku vodi do logičkog ekstrema svojim pristupom 'odzgo-prema-dolje', gdje pragmatiku postavlja na vrh hijerarhijske strukture lingvističkih razina (posljedično tome pragmatika upravlja semantikom, sintaksom itd). Iako FDG primat daje funkcionalno motiviranim jezičnim fenomenima, a mnogo manje arbitrarnosti, funkcionalistički ekstremizam ublažen je jednom od osnovnih postavki ovog pristupa. Naime, hipoteza pretpostavlja da se velik raspon formalnih kategorija može detaljno objasniti ako se povežu s pragmatičkim i semantičkim kategorijama ukorijenjenima u ljudskoj spoznaji i međuljudskoj komunikaciji. Ako i samo ako tu poveznicu nije moguće pronaći, FDG će se opredijeliti za arbitrarnost (proizvoljnost). Upravo ga ovakvo stajalište smješta na pola puta između radikalno formalističkih i radikalno funkcionalističkih pristupa jeziku i zahtijeva već predugo i prijeko potrebno proširenje tradicionalnih gramatika. Dvije bliske strukturalno-funkcionalne teorije jezika FDG-u zasigurno su gramatika uloga i referenci (RRG, Van Valin), te sistemska funkcionalna gramatika (SFG, Halliday). Ipak, postoji nekoliko ključnih razlika koje su nas navele na odabir gramatičkog modela u pitanju. Naime, FDG nema što za reći o tekstovima (kao SFG), no zanima ga utjecaj tekstualnosti na oblik jezičnih jedinica. FDG nije primarno zainteresiran za sintaksu (kao RRG), no uvažava i uočava važnost morfološke i sintaktičke organizacije u jezičnom kodiranju. Povrh svega, FDG daje jednaku težinu semantičkim i pragmatičkim čimbenicima u formiranju gramatike, a jezičnu teoriju nastoji spojiti s jezično-biološkim i kognitivnim radom. Naposljetku, FDG je teorija sposobna za pružanje okvira za otkrivanje i usporedbu jezičnih univerzalija, kao i za davanje 
temelja za tipološka istraživanja pojedinačnih jezika, što je pogodno za istraživanja u domeni historijske pragmatike.

Znanstveni doprinos, tj. svrha ovog istraživanja ogleda se u pružanju teorijskometodološkog pristupa namijenjenog za proučavanje i analizu komunikacije u cyber-prostoru. Problematiziranjem diskursnih oznaka, tj. određivanjem njihova statusa u sinkroniji kao i praćenjem njihova dijakronijskog razvoja očekuje se preciznije određenje kategorije u pitanju, a time i uvažavanje funkcionalističkih principa koji su se pokazali nezaobilaznima po pitanju pragmatike, diskursne razine jezika i novih komunikacijskih tehnologija.

\section{3. Pretpostavke i povezanost cyber-konteksta i diskursnih oznaka}

Hipoteze o diskursnim oznakama, proizašle iz prelimirnarne analize cyber-komunikacije (u vidu razmjene instant-poruka), sljedeće su:

H1 - Kratice i imitativi cyber-diskursa često obnašaju funkciju diskursnih oznaka zbog vlastite ekonomičnosti i zbog dočaravanja komunikacije licem u lice kao i parajezika koji je prati.

H2 - Paralingvističke informacije u tipovima cyber-komunikacije zasnovane isključivo na mediju teksta (poput instant-poruka ili chata) također se bilježe pismom kao i one lingvističke. Stoga šutnja [...], buka [poput poštapalica] i ostali parajezični fenomeni mogu biti analizirani kao pragmatičke funkcije.

H3 - Diskursne oznake u cyber-komunikaciji često nastaju na mjestima lingvističke (elokventne) šutnje s istaknutom ekspresivnom ili fatičkom funkcijom.

H4 - Diskursne oznake mogu evoluirati u poštapalice. Poštapalice time ne čine zasebnu potkategoriju diskursnih oznaka (jer narušavaju diskursnu kohereciju), već predstavljaju razvoj i jedan od produkata dijakronijskog procesa gramatikalizacije diskursnih funkcija (pragmatikalizacije).

Da bi se sve navedene hipoteze adekvatno testirale, neophodno je razjasniti kontekst u kojem se provodilo istraživanje. Ovdje je riječ o kontekstu za čije su potrebe formirane, prenesene i interpretirane diskursne oznake, riječ je o domeni cyber-diskursa. 


\subsubsection{Cyber-kontekst}

Računalno posredovani diskurs može se definirati kao oblik komunikacije koji nastaje kada ljudi stupaju u interakciju šaljući poruke s pomoću umreženih računala (Herring 2001: 612). Umjesto usvajajnja poprilično duge i jeziku neprilagođene anglofone terminologije, ovdje će

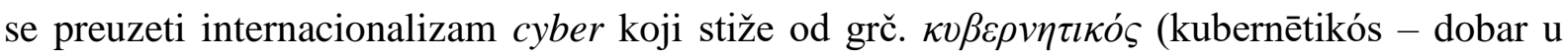
upravljanju, dobar pilot). Isprva je iz grčkog posuđen za imenovanje tada nove discipline kibernetike (kasne četrdesete godine 20. stoljeća), a danas je od izvedenog prefiksa postao samostalnom riječju sa svojstvima 'onoga na mreži'.

To je termin s iznimno širokim spektrom jer pokriva sve oblike komunikacije na internetu: od blogova, elektroničke pošte, preko rasprava na forumima, interakciju u virtualnim stvarnostima, do četova (od engl. chat - brbljati, brbljaonica). Ako se čista razmjena poruka s pomoću interneta potpomogne dodatnim sredstvima poput upotrebe fotografija i mogućnošću izgradnje čitavih identiteta, tada možemo govoriti i o interakciji unutar virtualnih svjetova $\mathrm{i}$ društvenih mreža. Istraživanja vezana za proučavaje cyber-diskursa dio su još većeg područja poznatog pod imenom računalno posredovana komunikacija (engl. Computer-mediated communication tj. CMC), u kojem je naglasak stavljen na proučavanje jezika (posebno mrežnog jezika u upotrebi), s tendencijom upotrebljavanja metodologije analize diskursa, konverzacijske analize i interakcijske sociolingvistike. Tome je još pridodan funkcionalni pogled na gramatiku te aspekte filozofije jezika i to nazivamo: cyber-pragmatikom.

Područje računalno posredovanog diskursa iznimno je široko, tako se primjerice iz sociopsihološkog pristupa obično proučavaju načini na koje pojedinci upotrebljavaju računalnu tehnologiju za vrijeme interakcije na interpersonalnoj razini, kako upravljaju dojmovima drugih, kako grade vlastite identitete na mreži i kako stvaraju i održavaju društvene odnose. Druga grana istraživanja unutar CMC-a proučava korištenje paralingvističkih odlika (poput emotikona), upotrebu pragmatičkih pravila (poput načela suradnje) te proučava različite jezične registre i terminologiju specifičnu za internetom određene kontekste. Spomenuta grana CMCa ponekad se spominje pod nazivom analize računalno posredovanog diskursa, tj. Computermediated Discourse Analysis (Beißwenger 2008). 
Interaktivno umreženo komuniciranje novijeg je vijeka, a omogućio ga je nastanak i širenje interneta, tj. globalne mreže (World Wide Web). 60-ih godina 20. stoljeća u Ministarstvu obrane SAD-a stvorena je eksperimentalna mreža širokog dosega pod imenom ARPANET s ciljem prijenosa podataka između udaljenih računala (Herring 2001). Već u sedamdesetima počela se upotrebljavati kao sredstvo interpersonalne komunikacije, isprva među informatičarima, a potom (80-ih godina) unutar akademskih zajednica i poslovne elite, da bi se 90-ih godina 20. stoljeća proširila i u privatnom sektoru. S razvojem interaktivnog umreženog komuniciranja rastao je i akademski interes za proučavanjem računalno posredovanog diskursa (engl. Computer-mediated Discourse tj. CMD), a s obzirom na činjenicu da tehnološki napredak nije dosegao svoj kraj, nova otkrića vezana za CMD tek dolaze.

\subsubsection{Cyber-diskurs}

Računalne mreže obično su percipirane kao vrsta, tj. medij komunikacije koji se razlikuje od pisma ili govorene riječi. On od svake od njih preuzima određene značajke, neke odlike su samo za njega specifične: gotovo da se nalazi negdje na razmeđi između pisanog teksta i govora, te poput znakovnih jezika tvori novi komunikacijski medij.

Da bismo mogli definirati njegova obilježja, morat ćemo promotriti obilježja specifična za pisanu i potom govorenu komunikaciju, koja je Crystal (2006: 28-30) sažeo u tablici 1 (prikazanoj na sljedećoj stranici). 
Tablica 1: Razlike između pisane i govorene komunikacije (Crystal 2006)

\begin{tabular}{|l|l|}
\hline Govor & Pisani tekst \\
\hline 1. Ovisan je o vremenu, dinamičan i trenutan. & 1. Ovisan je o prostoru, statičan i trajan. \\
\hline $\begin{array}{l}\text { 2. Između njegove produkcije i percepcije ne } \\
\text { postoji vremenski odmak. Spontan je i brz, } \\
\text { slobodnije konstrukcije, s mnogo ponavljanja, } \\
\text { ispravljanja. Granice rečenica često su nejasne. }\end{array}$ & $\begin{array}{l}\text { 2. Između produkcije i percepcije postoji } \\
\text { vremenski odmak. Pisanje omogućuje analizu, } \\
\text { pažljivu organizaciju i složenu rečeničnu } \\
\text { strukturu. Dijelovi diskursa jasno su } \\
\text { razgraničeni. }\end{array}$ \\
\hline $\begin{array}{l}\text { 3. Tipičan je kod interakcije licem u lice, koja se } \\
\text { također oslanja na mimiku i geste. }\end{array}$ & $\begin{array}{l}\text { 3. Zbog izostanka vizualnog kontakta } \\
\text { sudionici komunikacije ne mogu se osloniti na } \\
\text { kontekst i nije im dostupna izravna povratna } \\
\text { sprega. }\end{array}$ \\
\hline $\begin{array}{l}\text { 4. Za govor su karakteristični skraćeni oblici, } \\
\text { sleng i vulgarizmi. }\end{array}$ & $\begin{array}{l}\text { 4. Pismo odlikuju razrađena sintaksa i poduže } \\
\text { rečenice. }\end{array}$ \\
\hline $\begin{array}{l}\text { 5. Govor je pogodan za društvene i fatičke } \\
\text { funkcije. }\end{array}$ & $\begin{array}{l}\text { 5. Pismo je pogodno za bilježenje činjenica, } \\
\text { prenošenje ideja, za vježbanje pamćenja i } \\
\text { učenje. }\end{array}$ \\
\hline $\begin{array}{l}\text { 6. Jednom izgovoreno više se ne može povući. } \\
\text { Prekidi i preklapanja govora česti su i primjetni. }\end{array}$ & $\begin{array}{l}\text { 6. Pogreške u pismu mogu se ispraviti i čitatelj } \\
\text { za njih nikada ne mora saznati. Prekidi u } \\
\text { pisanju također su neprimjetni u krajnjoj } \\
\text { verziji napisanog. }\end{array}$ \\
\hline $\begin{array}{l}\text { 7. Za pismo su karakteristične grafičke odlike } \\
\text { poput: veličine i tipa slova, prostorna } \\
\text { organizacija teksta i sl., kao i postojanje } \\
\text { različitih pisanih žanrova poput tablica, } \\
\text { grafova, formula i td. }\end{array}$ \\
\hline $\begin{array}{l}\text { 7. Za govor je karakteristična prozodija: nijanse } \\
\text { intonaciji, glasnoća, tempo, ritam i pauze. }\end{array}$
\end{tabular}

CMD i od pisma i od govora preuzima određene odlike, no ovisno o podvrsti e-diskursa, $\mathrm{tj}$. o tome je li riječ o komunikaciji e-poštom, instant porukama, jesu li u pitanju chatovi, blogovi ili virtualni svjetovi, doći će do različitog omjera između obilježja preuzetih iz domene pisane i onih iz domene govorene komunikacije. To se najzornije može oslikati s pomoću grafičkog prikaza komunikacijskih medija, kao svojevrsnog linearnog kontinuuma čiju jednu krajnost predstavlja govor, a drugu pisani tekst.

Treba imati na umu da u ovaj čitav odnos između govora i pisma ulazi i parajezik. Parajezik obično prati govor i obilježje je neposredovane komunikacije. U slučaju CMC-a, parajezik se počeo manifestirati u pismu (npr. emotikoni), tj. neverbalne aspekti komunikacije počeli su se zapisivati. Također, ne smijemo zanemariti multimodalni karakter CMD-a koji buja s tehnološkim napretkom i doprinosi kontekstualizaciji pisane komunikacije (npr. upotreba slike, filma, glazbe i pisma). Samim time se kriteriji prozodije, grafičkog bogatstva i vizualnog konteksta mogu revidirati. 


\begin{tabular}{|c|c|c|c|c|c|}
\hline \multicolumn{3}{|l|}{ Pismo $\longleftarrow$} & \multicolumn{3}{|r|}{$\rightarrow$ Govor } \\
\hline \multicolumn{2}{|c|}{ globalna mreža } & e-pošta & chatovi & virtualni svjetovi & razmjena instant poruka \\
\hline $\begin{array}{l}\text { neovisna o } \\
\text { vremenu }\end{array}$ & $\begin{array}{l}\text { neovisni o } \\
\text { vremenu }\end{array}$ & $\begin{array}{l}\text { djelomice } \\
\text { ovisna o } \\
\text { vremenu }\end{array}$ & $\begin{array}{l}\text { djelomice } \\
\text { ovisni o } \\
\text { vremenu }\end{array}$ & $\begin{array}{l}\text { djelomice ovisni } \\
\text { o vremenu }\end{array}$ & ovisna o vremenu \\
\hline $\begin{array}{l}\text { ovisna o } \\
\text { prostoru }\end{array}$ & $\begin{array}{l}\text { ovisni o } \\
\text { prostoru }\end{array}$ & $\begin{array}{l}\text { djelomice } \\
\text { ovisna o } \\
\text { prostoru } \\
\end{array}$ & $\begin{array}{l}\text { djelomice } \\
\text { ovisni o } \\
\text { prostoru }\end{array}$ & $\begin{array}{l}\text { djelomice ovisni } \\
\text { o prostoru }\end{array}$ & $\begin{array}{l}\text { djelomice ovisna } \\
\text { o prostoru }\end{array}$ \\
\hline planirana & spontani & $\begin{array}{l}\text { planirana } \\
\text { /spontana }\end{array}$ & $\begin{array}{l}\text { spontani, ali } \\
\text { regulirani }\end{array}$ & $\begin{array}{l}\text { spontani, ali } \\
\text { regulirani }\end{array}$ & spontana \\
\hline jednostrana & jednostrani & $\begin{array}{l}\text { jednostrana } \\
\text { /obostrana }\end{array}$ & obostrani & obostrani & obostrana \\
\hline $\begin{array}{l}\text { siromašne } \\
\text { prozodije }\end{array}$ & $\begin{array}{l}\text { siromašne } \\
\text { prozodije }\end{array}$ & $\begin{array}{l}\text { siromašne } \\
\text { prozodije }\end{array}$ & $\begin{array}{l}\text { siromašne } \\
\text { prozodije }\end{array}$ & $\begin{array}{l}\text { siromašne } \\
\text { prozodije }\end{array}$ & $\begin{array}{l}\text { siromašne } \\
\text { prozodije }\end{array}$ \\
\hline $\begin{array}{l}\text { nemoguće ju } \\
\text { je odmah } \\
\text { revidirati }\end{array}$ & $\begin{array}{l}\text { nemoguće ih } \\
\text { je odmah } \\
\text { revidirati }\end{array}$ & $\begin{array}{l}\text { nemoguće ju } \\
\text { je odmah } \\
\text { revidirati }\end{array}$ & $\begin{array}{l}\text { nemoguće ju } \\
\text { je odmah } \\
\text { revidirati }\end{array}$ & $\begin{array}{l}\text { nemoguće ih je } \\
\text { odmah revidirati }\end{array}$ & $\begin{array}{l}\text { nemoguće ju je } \\
\text { odmah revidirati }\end{array}$ \\
\hline $\begin{array}{l}\text { razrađene } \\
\text { strukture }\end{array}$ & $\begin{array}{l}\text { slobodne } \\
\text { strukture }\end{array}$ & $\begin{array}{l}\text { varijabilne } \\
\text { strukture }\end{array}$ & $\begin{array}{l}\text { slobodne } \\
\text { strukture }\end{array}$ & $\begin{array}{l}\text { slobodne } \\
\text { strukture }\end{array}$ & $\begin{array}{l}\text { slobodne } \\
\text { strukture }\end{array}$ \\
\hline $\begin{array}{l}\text { vizualno } \\
\text { dekontekstu- } \\
\text { alizirana, ali } \\
\text { prilagodljiva }\end{array}$ & $\begin{array}{l}\text { vizualno } \\
\text { dekontekstu- } \\
\text { alizirani }\end{array}$ & $\begin{array}{l}\text { vizualno } \\
\text { dekontekstu- } \\
\text { alizirani }\end{array}$ & $\begin{array}{l}\text { vizualno } \\
\text { dekontekstu- } \\
\text { alizirani }\end{array}$ & $\begin{array}{l}\text { vizualno } \\
\text { dekontekstu- } \\
\text { alizirani, ali } \\
\text { prilagodljivi }\end{array}$ & $\begin{array}{l}\text { vizualno } \\
\text { dekontekstu- } \\
\text { alizirana, osim } \\
\text { ako se } \\
\text { upotrebljava } \\
\text { kamera }\end{array}$ \\
\hline $\begin{array}{l}\text { grafički } \\
\text { bogata }\end{array}$ & $\begin{array}{l}\text { grafički } \\
\text { siromašni }\end{array}$ & $\begin{array}{l}\text { grafički } \\
\text { siromašni }\end{array}$ & $\begin{array}{l}\text { grafički } \\
\text { siromašni }\end{array}$ & grafički bogati & $\begin{array}{l}\text { grafički } \\
\text { siromašna } \\
\end{array}$ \\
\hline
\end{tabular}

Ipak, kao što prikazuje grafički prikaz 1, razmjena instant poruka posjeduje najviše karakteristika govorene komunikacije, bez obzira na činjenicu što je pisana. Ono što je stavlja na sam desni kraj kontinuuma pismo/govor i izdvaja od ostalih vrsta CMD-a, njezina je potpuna ovisnost o dimenziji vremena. Sinkronija u razmjeni instant poruka kod korisnika ostavlja dojam komunikacije licem u lice, ipak taj dojam ponekad narušava manjak fizičkog konteksta i nepostojanje simultanosti proizvodnje i procesiranja govora. Odmičući se od razmjene instant poruka prema suprotnom kraju tablice, sa svakom sljedećom vrstom CMD-a obilježja govora zamjenjuju se karakteristikama pisane komunikacije. Tako komunikacija u virtualnim svjetovima gubi potpunu ovisnost o vremenu i postaje regulirana, no obogaćena je grafički. Chatovi također ne posjeduju potpunu ovisnost o vremenu (mogu biti i posve asinkroni) i često su regulirani (tj. moderirani). Dolazeći do elektroničke pošte i njezina položaja u odnosu prema govoru i pisanom tekstu, te u odnosu prema razmjeni instant poruka, činimo velik skok posebice ako je riječ o formalnoj e-pošti. Ako je riječ o neformalnoj komunikaciji e-poštom, njezina se 
obilježja neće mnogo razlikovati od obilježja asinkronih chatova. Blogovi, a posebno globalne mreže posjeduju najviše obilježja pisane komunikacije, zbog čega se u najvećoj mjeri razlikuju od razmjene instant poruka. Ono što ih stavlja na suprotne krajeve našeg kontinuuma pismo/govor prije svega su obilježja ovisnosti tj. neovisnosti o prostoru i vremenu, iz čega proizlaze gotovo sve njihove ostale odlike. No ono što je zajedničko svim navedenim vrstama računalno posredovanog diskursa jest njihova vještina kombiniranja pojedinih obilježja pisma i govora, ovisno o cilju i svrsi komunikacijskog djelovanja.

Odlike različitih sustava za odašiljanje poruka uvelike oblikuju CMD, tj. omogućuju varijacije unutar njega. Ovdje ćemo spomenuti osam ključnih karakteristika koje navodi Herring (2001), a one su sljedeće:

1. Sinkronija, tj. istovremeno sudjelovanje u komunikaciji - neki sustavi za odašiljanje poruka je omogućuju, poput sustava za slanje instant-poruka, chatova i virtualnih svjetova. E-pošta i blogovi asinkroni su.

2. Ograničenje veličine poruke.

3. Trajnost teksta, s obzirom na to koliko neka poruka ostaje dostupna primatelju.

4. Izbor komunikacijskih aplikacija koje pruža sustav za komuniciranje.

5. Jednostrana ili obostrana komunikacija.

6. Mogućnost anonimnog slanja poruka.

7. Mogućnost odabira od koga ćemo primati poruke, a od koga nećemo.

8. Dostupnost drugih kanala komunikacije, osim pisma.

Svaki sustav za komunikaciju s pomoću interneta, bilo da je riječ o sustavima za slanje instant poruka ili e-pošte, odlikuje različita kombinacija navedenih obilježja. U sljedećih nekoliko odlomaka osvrnut ćemo se samo ukratko na neke podvrste e-diskursa, s iznimkom razmjene instant poruka, čija će tema biti detaljnije obrađena u zasebnom podnaslovu. ${ }^{20}$

Elektronička pošta (e-mail) označava upotrebu umreženih računala sa svrhom prijenosa poruka među korisnicima. Najčešće se odnosi na poruke poslane u privatne poštanske sandučiće, za razliku od poruka koje se razmjenjuju na chatovima (Crystal 2006: 11). Razmjene e-pošte mogu se odvijati između suradnika, prijatelja, članova obitelji, trgovaca i kupaca, kolega, te s obzirom na tu raznolikost poruke mogu varirati u veličini i stilu.

\footnotetext{
${ }^{20}$ Detaljnije o različitim tipovima elektroničkog diskursa pogledaj u: David Crystal, Language and the Internet, (Cambridge; New York: Cambridge University Press, 2006.).
} 
Chatovi su kontinuirane rasprave na određenu temu, organizirane na posebnim internetskim stranicama (Ibid). S obzirom na sinkroniju oni mogu biti sinkroni i asinkroni, tj. interakcija se među korisnicima može odvijati u realnom vremenu ili s vremenskim odmakom između odašiljanja, odnosno primanja poruka. Neki su chatovi globalni, dok su drugi lokalni, neki podliježu uredništvu od strane moderatora, a neki ne.

Virtualni svjetovi predstavljaju zamišljena okružja unutar kojih ljudi stupaju u maštovitu društvenu interakciju zasnovanu na pismu (Ibid. 12). Svaki korisnik zapravo preuzima ulogu nekog lika unutar igre koju igra, koja predstavlja njegov virtualni svijet, te s pomoću vlastitog lika komunicira sa svojim suigračima.

Globalna mreža (World Wide Web) skup je svih računala spojenih na internet, koji sadrži svima dostupne dokumente s pomoću upotrebe HTTP-a, tj. the HyperText Transfer Protocol (Ibid. 13). Drugim riječima, ona predstavlja sve vrste informacija, svo ljudsko znanje kojem se može pristupiti na internetu.

Blogovi su došli do izražaja početkom dvijetisućitih, a sam naziv blog dolazi od engleske riječi weblog, tj. mrežni dnevnik (Ibid. 15). Blog zapravo predstavlja internetsku stranicu nekog korisnika, na kojoj on ili ona povremeno objavljuje poruke ili tekstove. Mnogi su blogovi javne inačice osobnih dnevnika, a njihov oblik, veličina i stil variraju od korisnika do korisnika. Danas imamo i tzv. micro-blogging u vidu objava na Twitteru, također su se pojavile tzv. priče i sažeci na Instagramu koji čine vrlo slično, no baziraju se na videu ili fotografiji. Na posljetku, blog se sve češće može pronaći u video obliku i tada ga nazivamo vlog (od engleskih riječi video+blog). 


\subsubsection{Instant poruke}

Instant poruke, tj. izvorno iz engleskog jezika Instant Messaging $\left(I M^{21}\right)$, jedan su od oblika cyber-diskursa. Zapravo spadaju pod širi pojam chata na mreži, no od chata u užem smislu razlikuju se po tome što se odnose na komunikaciju među osobama koje se međusobno dobro poznaju (koji se koriste listama kontakata ili prijatelja), dok se chat u užem smislu odnosi na komunikaciju između mnoštva najčešće anonimnih korisnika. IM omogućuje elektroničke razgovore u realnom vremenu (sinkron je), zasnovan je na pisanom tekstu (iako je u posljednje vrijeme dostupno korištenje kamera i mikrofona), a može se odvijati između dviju ili više osoba. Da bi se komunikacija ostvarila, korisnici se moraju služiti istim softverom za IM (npr.: WhatsApp, Viber, Facebook Chat, Skype, G-talk tj. Hangouts), tekst koji se razmjenjuje prenosi se mrežnim putem (najčešće preko interneta ili lokalne mreže) i komunikacija se naravno odvija s pomoću računala (ili mobitela). Dakle, kao što je Crystal lijepo sažeo:

„Sve do pojave instant poruka (IM) nije postojala mogućnost razgovora na mreži putem računala, $\mathrm{u}$ realnom vremenu, s drugom osobom ili malom skupinom prijatelja ili poznanika." (Ibid. 247-248). ${ }^{22}$

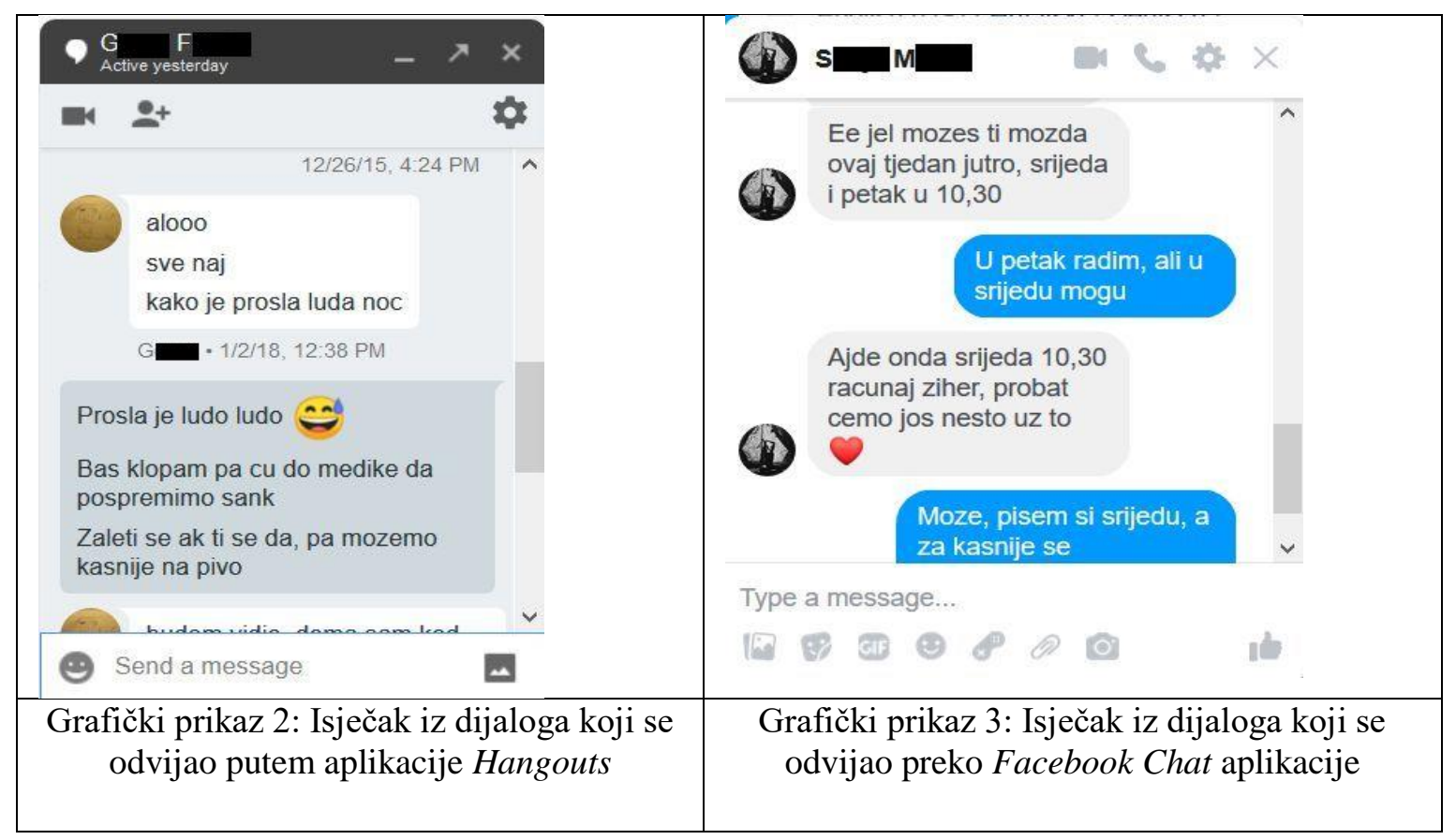

\footnotetext{
${ }^{21}$ IM je međunarodno poznata i priznata skraćenica engleskog termina Instant Messaging te ćemo se njome služiti zbog ekonomičnosti, prepoznatljivosti i razumljivosti u akademskim krugovima, ali i čitavom društvu. Instant messaging u hrvatskom je prijevodu razmjena instant poruka, što podrazumijeva skraćenica IM.

${ }^{22}$ Prethodno je naveden slobodan hrvatski prijevod, dok citat u originalu glasi: „For anyone who wanted to use a computer to carry on a natural conversation online in real time with another person, or a small group of friends or acquaintances, there was nothing to allow that to do it - until instant messaging (IM).“
} 
Tehnologija koja je omogućila razmjenu instant poruka u današnjem smislu prvi se puta pojavila 1996. godine sa softverom ICQ („I seek you“) (Ibid. 248). Danas postoji mnoštvo različitih softvera za IM, koji nisu međusobno kompatibilni (poput primjerice Skypea i Whatsappa), međutim pojavila se težnja za stvaranjem standardnog protokola zbog ekonomičnosti, te su se pojavili IM sustavi koji omogućuju komunikaciju među kontaktima prijavljenima na inače nekompatibilnim IM softverima (primjerice: Trillian). ${ }^{23}$ Danas je komunikacija u obliku IM-a poprimila iznimno široke razmjere, što pokazuju sljedeće brojke: 2003. godine procijenjeno je da u SAD-u ima 53 milijuna aktivnih korisnika IM-a (Crystal 2006), Windows Live Messenger upotrebljava oko 330 milijuna korisnika (podatak iz 2009.) ${ }^{24}$, ICQ upotrebljava 40 - 50 milijuna ljudi $^{25}$, a prema statistikama Facebooka, Facebook Chatom se koristi oko 117 milijuna ljudi. ${ }^{26}$

IM omogućuje izravno otvaranje komunikacije s imenovanom skupinom kontakata, tzv. contact list, buddy list, friend list (Crystal 2006: 14). Na takvim listama ponekad su istaknuti statusi navedenih konatakata, primjerice: je li netko na mreži (online) ili nije (offline) ${ }^{27}$, tko je zauzet (busy), a tko udaljen od računala (away). U nekim slučajevima, kao što prikazuje i sljedeći primjer razgovora s pomoću Whatsapp-a, moguće je vidjeti posljednje vrijeme aktivnosti našeg potencijalog sugovornika (ispod imena, u prozorčiću samog razgovora).

\footnotetext{
${ }^{23}$ Naime, nepraktično je služiti se nekolicinom različitih softvera za IM zbog barem dvaju osnovnih razloga: loše preglednosti zbog nesistematizirnosti i nepotrebng opterećivanja radne memorije računala.

${ }^{24}$ Dostupno na URL:

http://messengersays.spaces.live.com/Blog/cns!5B410F7FD930829E!73591.entry?wa=wsignin1.0\&sa=9262905 94, 10. 12. 2010.

${ }^{25}$ Dostupno na URL: http://news.cnet.com/8301-1023_3-10449039-93.html, 10. 12. 2010.

${ }^{26}$ Dostupno na URL: http://www.insidefacebook.com/2009/02/23/facebook-chat-latest-stats-whats-comingnext/, 10. 12. 2010.

${ }^{27}$ Osoba također može izabrati mogućnost da ostane nevidljiva (invisible) vlastitim kontaktima te će njima pisati da on/ona nije na mreži.
} 


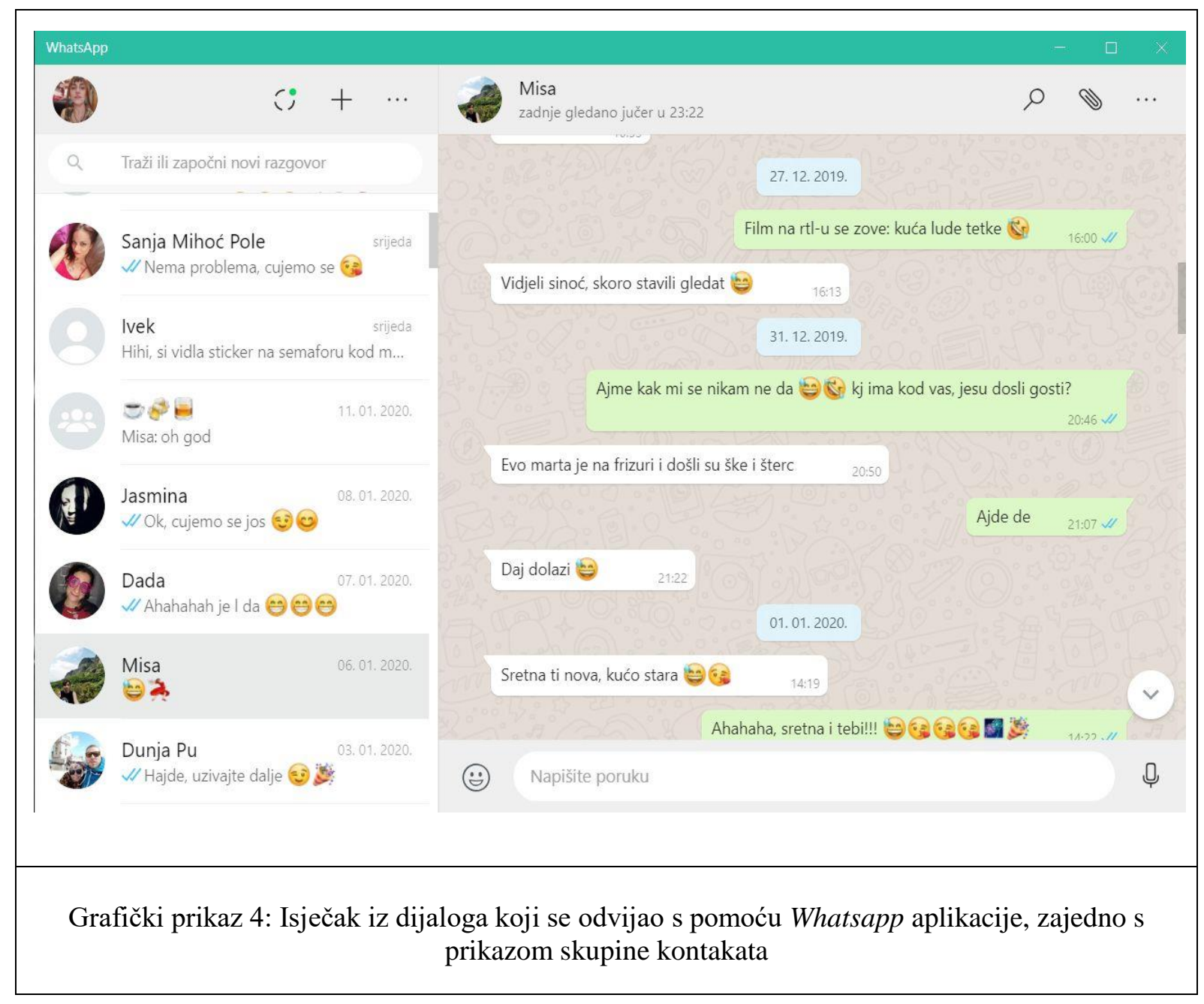

Da bismo započeli razgovor s nekim od kontakata, moramo nju ili njega odabrati s naše liste tako da kliknemo na ime kontakta i odaberemo opciju za slanje instant poruke. Tada će nam se otvoriti novi prozor podijeljen na dva dijela, od kojih jedan (obično donji dio) služi za naš unos teksta, koji jedino mi sami vidimo te u kojem kreiramo vlastitu poruku prije no što je pošaljemo. Drugi (gornji) dio prozora prikazuje razmjenu između nas i osobe s kojom razgovaramo, dakle naše i njegove/njezine poslane iskaze, obično u obliku „oblačića”, kao u stripu. Kako se razgovor nastavlja, tako se razmijenjeni tekst u gornjem dijelu prozora pomiče, te one instant poruke koje su najranije poslane nestaju iz prozora (no dostupne su ako pomaknemo tekst prema dolje). Također, većina suvremenih aplikacija uz mogućnost slanja instant poruka omogućuje slanje video poruka, glasovnih poruka, sudjelovanje u videopozivu, slanje elektroničke pošte i kreiranje kratkih pozdravnih poruka (tj. statusa) čija funkcija primjerice može biti dijeljenje vlastitih raspoloženja s našim prijateljima. Takve se poruke nalaze uz sam avatar (grafički prikaz: fotografiju ili crtež koji predstavlja određenog korisnika na mreži) na popisu kontakata. Uz sve navedeno, svaki korisnik može izabrati izgled prozora vlastitog messengera, $\mathrm{tj}$. može 
izabrati njegovu boju, uzorke pozadine, te može birati veličinu, boju i vrstu slova kojima se koristi za svoje instant poruke i slično. Osim toga, softveri za IM uz slanje poruka omogućuju slanje različitih vrsta datoteka (npr. fotografija, pdf i word dokumenata), igranje igara, korištenje mikrofona i kamere, te još mnoštvo drugih mogućnosti. Svi protekli dijalozi čuvaju se u obliku dnevnika (tzv. message log), što ljudima omogućuje da kasnije pročitaju o čemu su razgovarali.

IM posjeduje mnoštvo specifičnih lingvističkih odlika, od kojih su najznačajnije:

- skraćenice u obliku akronima ili rebusa (npr. lol, btw, omg, l8r),

- neispravljene pogreške u tipkanju,

- nekorištenje velikih početnih slova,

- izbjegavanje upotrebe točke (iako se upitnici, uskličnici i trotočje upotrebljavaju),

- neformalnost (kolokvijalnost),

- sleng,

- vulgarizmi,

- imitativi.

Ovaj je kontekst odabran jer je internet kao medij fluidan (sklon promjenama, intertekstualnosti, multimodalnosti i otvorenosti pristupa), ne sputava jezičnu upotrebu i potiče na razvoj jezične kreativnosti. No, uz navedene pozitivne aspekte odabran je zbog toga što se u njemu teže ostvaruje tekstna koherentnost i kohezivnost, jezična ekonomija i signalizacija jezičnih funkcija zbog manjka paralingvističkih odlika komunikacije, asinkroniciteta i manjka zajedničkog konteksta.

Svi spomenuti faktori, kako pozitivni tako i negativni, stvorili su idealno okružje za razvoj i proliferaciju diskursnih oznaka, kao i nepresušan izvor originalne i svakodnevne jezične upotrebe koja nije mijenjana, kako ni zbog metodoloških, tako ni zbog jezično-političkih strujanja. 


\section{CYBER-PRAGMATIKA}

U prethodnim poglavljima koja su obrađivala problematiku cyber-konteksta, diskursa kao i u podnaslovu vezanom za komunikacijsku kompetenciju cyber-svijeta, načeli smo temu cyberpragmatike. No, prije svega je važno imati na umu da tu može biti riječ o dvjema različitim stvarima. Bitno je razlikovati cyber-pragmatiku u užem smislu od one u širem smislu.

Uže područje cyber-pragmatike veže se uz teoriju Francisca Yusa $(2011,2018)$. Njegovim riječima, bila bi to primjena kognitivne pragmatike (tj. teorije relevatnosti) na interakcije korisnika na mreži. Njezin je osnovni cilj analiza produkcije i interpretacije informacija u kontekstu interneta. Osim toga, ovaj se pristup interesira za načine na koje korisnici pristupaju kontekstulanim informacijama koje su na mreži često ograničene. Nadalje, Yus (2011: 15) ističe da je središnji cilj njegove cyber-pragmatičke analize utvrđivanje do koje mjere obilježja cybermedija (npr. sinkronost/asinkronost, tekstualnost/verbalnost) utječu na procjenu relevantnosti kod korisnika.

Mnogo šire područje bila bi cyber-pragmatika kao domena istraživanja komunikacije na mreži. Pod ovo bi područje spala i Yusova teorija, kao i mnoge druge koje se bave računalnoposredovanim diskursom, tj. istražuju jezik u upotrebi u kontekstu interneta. Ovo se područje time ne ograničava samo jednom pragmatičkom teorijom i metodom poput teorije relevantnosti koju je usvojio Yus, već ovisno o predmetu istraživanja implementira skup raznih pragmatičkih metoda: od kritičke analize diskursa, konverzacijske analize, tekstne analize, analize govornikove intencije, govornih činova, do interakcijske sociolingvistike i brojnih drugih pristupa. Drugim riječima, cyber-pragmatiku u širem smislu opisali bismo kao jedinstveno i sveobuhvatno istraživačko područje ljudske komunikacije na mreži.

Proučavanjem i analizom cyber-komunikacije znanstvenici su s vremenom došli do dvaju dijametralno suprotnih zaključaka o prirodi komunikacije (Yus 2018):

1. U prvom se izražava stav da sama posredovanost komunikacije medijem interneta ne mijenja prirodu same komunikacije i time se cyber-komunikacija zapravo ne razlikuje od komunikacije licem u lice.

2. U drugom se izražava stav da internet kao medij čini veliku razliku u prirodi komunikacije jer se ona odvija u okruženju koje je „pročišćeno” od migova (cues-filtered 
invironment) i $\mathrm{s}$ manje resursa za kontekstualizaciju (nedostatak neverbalne komunikcije).

Susan Herring, američka lingvistkinja i sociopragmatičarka koja se istaknula svojim radom na računalno posredovanoj komunikaciji, prethodna dva viđenja odnosa komunikacije i interneta odvela je korak dalje. U zborniku Pragmatics of Computer-mediated Communication, Herring (2013) predlaže treću perspektivu tj. shvaćanje da internet omogućuje novu vrstu sudjelovanja, fragmentacije, nove načine sukonstruiranja značenja koji nadilaze tradicionalne pojmove razgovora, narativa, argumentacije i drugih srodnih pojmova.

Ako se odlučimo za drugi ili treći prethodno navedeni stav, time ćemo prihvatiti činjenicu da medij kojim se poruka prenosi ujedno i utječe na samu poruku, što je među prvima istaknuo čuveni Marshall McLuhan (2008). S obzirom na to da se i sami s time slažemo, kod primjene klasične pragmatike na primjere komunikacije na mreži morat ćemo na umu imati sve promjene do kojih je došlo u sastavnicama komunikacijskog lanca. Yus (2018) nam ovdje pomaže, navodeći da su se pojavili novi autori/govornici (kolektivno stvaranje i autorstvo, hibridizacija čitatelja/pisca), novi oblici teksta (multimodalni i nelinearni), nova sučelja (multimodalna i prilagođena korisniku), nove vrste čitatelja/slušatelja (aktivni, dinamični, doprinose sadržaju, sudjeluju) i nova tipologija interpretacije (sužena je jer je izbor uvijek na primatelju poruke). Drugim riječima, ono što razlikuje cyber-pragmatiku od klasične jest sljedeće:

1. Vrsta pošiljatelja - u cyber-svijetu i dalje postoje individualni pošiljatelji poruka (npr. autori blogova, instant poruka, e-pošte), ali dolazi do povećanja višestrukih autorstava i kolaborativnih diskursa (npr. Wikipedia).

2. Vrsta interpretativnog puta - više nema linearnog puta procesiranja zbog otvorenog izbora u vidu poveznica (engl. links), okvira (engl. frames), tragova i multimedijskog sadržaja. Kohezivnost i koherentnost većinom se postižu tzv. krpanjem pri zaključivanju (engl. inferential patchwork) ${ }^{28}$, pri čemu korisnik gradi smisao s pomoću različitih fragmenata diskursa iz različitih izvora, raznovrsnih diskurzivnih obilježja.

3. Vrsta diskursa i poruka - diskurs se rascjepkao na mnoštvo žanrova unutar istog medija (interneta), prilagođavajući se potrebama korisnika i tehnološkom razvoju. Stoga na internetu primjerice možemo istvremeno pisati poruku e-pošte, objaviti status na

\footnotetext{
${ }^{28}$ Takvu je metodu „krpanja“ već objasnio francuski antropolog Claude Lévi-Strauss u svojem djelu Divlja misao (1962) pojmom brikolaža. Brikolaž je objašnjen kao tehnika ponovne upotrebe već postojećih materijala s ciljem rješavanja novih problema. Njegov pojam nešto je kasnije Jacques Derrida primijenio na polje diskursa, percipirajući svaki diskurs kao svojevrsni brikolaž. Da bismo takav diskurs uspješno interpretirali, prisiljeni smo sklapati komadiće ne bi li dobili potpunu sliku (što možemo nazvati brikolažnim zaključivanjem).
} 
društvenoj mreži i sudjelovati u razmjeni instant poruka. Također, diskurs je postao multimodalan, pri čemu je jezik samo jedan od semioloških kodova (npr. memovi).

4. Vrsta primatelja - kao i u slučaju pošiljatelja poruke, u cyber-svijetu povećava se broj grupnih razgovora, pri čemu svi sudionici zajedno sudjeluju u formiranju i tumačenju značenja te grupno određuju inferencijalni put. Pojedinačni primatelji i dalje postoje, najviše u (privatnim) mrežnim dijalozima (npr. instant poruke).

5. Vrsta ko(n)teksta i koda - hibridizacija govora i pisma zbog nedostatka zajedničkog fizičkog konteksta pri komunikacijskom procesu na mreži i pokušaj oponašanja/prezentiranja komunikacije licem u lice. Novi kontekst uzrokovan obilježjima novog medija potaknuo je promjenu u tekstu. Te su se promjene manifestirale kao nove tehnike oralizacije i kontekstualizacije poput emotikona i neuobičajene grafije.

S obzirom na navedene promjene potrebno je prilagoditi već postojeću metodologiju. Tako pri analizi razgovora na mreži možemo graditi na postavkama konverzacijske analize, pri analizi statusa na društvenim mrežama možemo razrađivati teoriju govornih činova, ali na umu moramo imati sva odstupanja od klasične komunikacije licem u lice, što nas naposljetku možda dovede do nekih novih spoznaja.

Pragmatika kao disciplina pruža višestruke mogućnosti jasne primjene na područje cyberkomunikacije. Njezine metode i teorijski okviri mogu se nositi sa svakodnevicom interneta, te je analizirati: od žustrih javnih diskusija na forumima ili u komentarima članaka „škakljivih” socijalnih tema, preko memova kao novog oblika političkog djelovanja, pa sve do statusa, hashtagova i parajezika mrežnog chata. Kao izdanak lingvističke discipline koja se u općem smislu bavi ljudskom komunikacijom logično je da će se cyber-pragmatika baviti cyberinačicom svoga predmeta istraživanja. Ovdje je stoga ne bismo ograničili na spoj kognitivne pragmatičke teorije s komunikacijom na mreži, već bismo rekli da je cyber-pragmatika grana jezikoslovlja koja spada pod širu domenu pragmatike, no svoj predmet istraživanja ograničava na cyber-komunikaciju, tj. cyber-diskurs. Ovisno o problematici i žanru, cyber-pragmatika se koristi i može se služiti svim metodama (opće) pragmatike, s ponekim prilagodbama. Neke od potencijalnih prilagodbi analitičkih i teorijskih pristupa bit će izložene, posebice kada će biti riječi o konverzacijskoj analizi i njezinoj primjeni na mrežne dijaloge. Također, zanimljivo je vidjeti što se događa s Griceovom teorijom implikatura i maksimama načela kooperativnosti, kao i s izvođenjem identiteta posredstvom jezika (Goffman, interakcijska sociolingvistika) na mreži. Etnometodologija nam ovdje također može iznimno pomoći, zbog važnosti koju pridaje 
kulturnom i društvenom kontekstu. Jednako tako možemo promatrati iskazivanje pristojnosti na mreži (Leech 1983) i/ili vidjeti kakve nam sve gratifikacije donosi cyber-komunikacija kao npr. pojavu hiperpersonalnosti (Walther 1996).

Temi impersonalnosti i interpersonalnosti cyber-komunikacije značajno je doprinio Joseph B. Walther (1996) svojim modelom procesiranja socijalnih informacija i pojmom hiperpersonalne interakcije. Osnovna pretpostavka Waltherove teorije ukazala je na činjenicu da razlika između komunikacije licem u lice i komunikacije na mreži ne ovisi o količini prenesenih socijalnih informacija, već o brzini njihove razmjene. Drugim riječima, pretpostavlilo se da će gomilanje interpersonalnih učinaka u računalno posredovanoj komunikaciji biti sporije, ali da ono neće izostati. Ovom se perspektivom priznalo da se cyberkomunikacijom prenosi manje socijalnih informacija (ponajviše zbog manjka neverbalnih migova), no uvažio se potencijal korisnika da se prilagodi novoj okolini. Walther je tu prilagodbu novom mediju objasnio pojmom hiperpersonalne komunikacije. Definirao ju je kao računalno posredovanu komunikaciju koja je društveno poželjnija i intimnija od one koju možemo iskusiti licem u lice. Naglasio je da je ono što omogućava ovaj tip komunikacije smanjena dostupnost neverbalnih migova u cyber-kontekstu, prilike za selektivno samopredstavljanje i pogodan kontekst za idealizaciju slike drugih.

Naposljetku, pokazalo se da hiperpersonalnost nije obilježje isključivo neformalne komunikacije kao ni isključivo kooperativne komunikacije, već da se javlja i u formalnim kontekstima te prilikom konfliktnih i nekooperativnih situacija. Također, ovom se teorijom pružio odgovor na oprečne podatke o prirodi komunikacije na mreži kao istovremeno impersonalne i hiperpersonalne. Walther je pokazao da medij interneta nije inherentno impersonalan ili hiperpersonalan, već da korisnicima nudi obje mogućnosti.

Jasno je da u cyber-svijetu djeluju jednake komunikacijske strategije, procesi zaključivanja i interakcije kao u komunikaciji licem u lice, no s obzirom na to da je došlo do određenih promjena u prirodi svih segmenata komunikacijskog lanca, valja ih uzeti u obzir pri pragmatičkoj analizi. Stoga, uz sve glavne pragmatičke teme (deikse, implikature, govorne činove, argumentaciju, intencionalnost, interpretaciju, presupozicije i td.), u domenu cyberpragmatike pridodali bismo sociolingvističke i semiološke aspekte komunikacije. Bez njih sam kontekst jezične upotrebe nije potpun: socijalna dinamika cyber-svijeta nešto je drugačija zbog anonimnosti korisnika i medijatiziranosti poruka, a multimodalnost poruka zahtijeva semiološke pristupe. Time bismo zaključili vlastito određenje područja i predmeta cyber- 
pragmatike kao relativno novog, tek bujajućeg sociopragmatičkog i semiološkog istraživačkog prostora.

\section{1. Cyber vs. kiber - pojašnjenje terminologije}

Kontekst u kojem će se diskursne oznake proučavati u ovome radu, a posebice terminologija koja se uz njega vezuje, zahtijevaju dodatnu pažnju.

Umjesto često korištene, izravno prevedene i neprecizne te strogo opisne terminologije potekle s anglofonog govornog područja: računalno posredovani diskurs, ovdje smo se odlučili za nešto kraći termin, mnogo bolje i preciznije pokrivenosti. Riječ je o terminu cyber-diskurs te o upotrebi prefiksoida cyber.

Računalno posredovani diskurs (engl. Computer-mediated Discourse), kako ga definira Herring (2001: 612), jest oblik komunikacije koji nastaje kada ljudi stupaju u interakciju šaljući poruke s pomoću umreženih računala. Navedena je definicija zadovoljavajuća, no terminologija je problematična. Naime, termini poput „,informatički“, „,informacijski“, „kompjuterski““, „računalni“ pojmovno ne odgovaraju ili zbog općenitosti ili preuskog značenja te u sve češćoj upotrebi s razlogom pronalazimo prefikse cyber ili kiber. No i ovdje treba biti iznimno oprezan, jer pri odabiru termina u duhu hrvatskog jezika potrebno je razlikovati porijeklo ovih dvaju termina koja nemaju isto izvorište pa tako ni značenje.

Za potrebe ovog rada i zbog prirode same teme prvenstvo je dano prefiksoidu cyber u odnosu na kiber iz nekoliko sljedećih razloga.

Naime, u pitanju je slučaj homonimije u engleskom jeziku kao jeziku davatelju (cybernetics vs. cyberspace), dok u hrvatskom postoji razlika u obliku (kiber vs. cyber) koja se ne smije zanemariti i koja se treba iskoristiti jer prati logiku semantike i etimologije. Kibernetika i kiberodnose se na kibernetiku kao disciplinu definiranu prema Norbertu Wieneru, dok cyber dolazi u upotrebu mnogo kasnije, usponom interneta i virtualnog prostora i ne odnosi se ni na kakvu znanost ili znanstvenu disciplinu. Neologizmi poput ovih upotrebljavaju se neprestano kroz povijest i često su stranog porijekla (kao npr. radio, televizija, autobus), no s obzirom na to da smo ih naučili kao djeca, prihvatili smo ih kao riječi svog materinskog jezika. Danas je jedan od osnovnih izvora neologizama područje tehnologije i njezin napredak, no problem nastaje s riječima koje se javljaju za vrijeme naših života. U ovom slučaju to su najčešće posuđenice iz 
engleskog jezika. Za to postoje dva značajna razloga: engleski je jezik svjetska lingua franca zbog povijesne činjenice da je Ujedinjenog Kraljevstvo bilo jednom od najvećih svjetskih kolonizacijskih sila, ali i zbog činjenice da je to jezik konvencije u području informacijskih i komunikacijskih tehnologija razvijenih u SAD- ${ }^{29}$. Time se uloga engleskog jezika kao linguae france dodatno ojačala.

Riječ cyber danas je jedan od najzastupljenijih neologizama u čitavom svijetu (ne samo engleskom jeziku) i upotreba joj se sve više širi. Prvi se puta u ovome (suvremenom) smislu pojavila osamdesetih godina prošloga stoljeća u novotvorenici cyber-prostor (engl. cyberspace), koju je osmislio i upotrijebio kanadsko-američki SF pisac William Gibson u svojem poznatom romanu Neuromancer (1984). Gibson je pojmom cyber-prostor nastojao opisati zajedničko virtualno okruženje, stoga je taj pojam postao nazivom za sve suvremene informacijsko-komunikacijske tehnologije koje omogućavaju umrežavanje tehničkih i društvenih sustava. Suvremeni pojam cyber-prostora, pa tako i cyber-diskursa, cyberkomunkacije i cyber-pragmatike potječe od Gibsona, a ne od koncepta kibernetika Norberta Wienera.

No vratimo se na kibernetiku. Četrdesetih godina 20. stoljeća pojavila se riječ kibernetika koju je (također sasvim proizvoljno) osmislio američki matematičar Norbert Wiener ne bi li imenovao novu disciplinu koja se odnosila na znanstveno proučavanje upravljanja i komunikaciju u biološkim i tehničkim sustavima. Po njegovu se mišljenju kibernetika bavi upravljanjem sustavima primjenom informacija koje se kreću procesima i povratnim spregama. Prije Wienera ovim su se pojmom koristili i drugi: od Platona do Ampera, koji su kibernetiku pak doživljavali uglavnom kao upravljanje ljudima i društvenim sustavima (Mladenović 2009). Taj opći koncept automatskog upravljanja u praksi ne odgovara u potpunosti suvremenoj primjeni informacijskih i komunikacijskih tehnologija koje se odnose na računala, internet i virtualni prostor, a usporedbe hrvatskog s praksom u slovenskom i germanskim jezicima koji u pravilu uvijek koriste kiber a nikada cyber nisu održive zbog drugačije ortografske norme.

Uza sve dosad navedeno, pri kasnijem prevođenju ovog termina na hrvatski jezik primijenjeno je pravilo da se pri prevođenju riječi čije je originalno porijeklo iz latinskog ili starogrčkog upotrebljava i originalni izgovor. Stoga je prihvaćena kibernetika, što je u tom slučaju sasvim u redu, no u prethodnom slučaju sa cyber-prostorom nije ispravno jer je izvorište

\footnotetext{
${ }^{29}$ Iako su računala postojala puno prije pojave interneta, u smislu u kojem ih poznajemo danas (elektronička računala) osmišljena su u drugoj polovici prošlog stoljeća za potrebe američke vojske. To se kasnije proširilo na američku akademsku zajednicu, da bi s vremenom ušlo u sve pore današnjeg društva.
} 
pojma cyber egleski jezik i kultura, tj. SAD: mjesto razvoja interneta, a ne kibernetika Norberta Wienera ili antička Grčka.

Da sažmemo, suvremeni pojam cyber potječe od Gibsonove koncepcije tog pojma, a ne od koncepta kibernetike Norberta Wienera, koji se pak izravno nadovezuje na starogrčki pojam kibernetikós. Ipak, između ovih dvaju sasvim različitih pojmova postoje zajedničke točke, što je i dovelo do ove problematike. Na primjer pod primijenjenu kibernetiku bi spadale informatika (računarstvo i informatologija) i bionika, dok je cyber-prostor područje apstraktne stvarnosti ideja, informacija i logike.

Etimološki, prefiksoid cyber dolazi od engl. cyberspace i izgovara se kao i u izvornom obliku /sajber/. Iz istog mu razloga grafiju ostavljamo nepromijenjenom, osim spojnice ne bi li se naglasilo strano porijeklo, izgovor i razlikovanje od bliskoznačnice kiber. S druge strane,

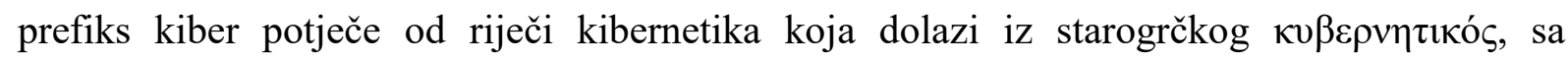
značenjem upravljati, rukovoditi, kormilariti. Njezin je anglosaksonski izgovor/sajber/, a slovenski i germanski /kiber/. Oba su pojma preuzeta od zajedničkog starogrčkog termina, jer njihovi su ih suvremeni autori proizvoljno odabrali i povezali s različitim konceptima.

Uz etimologiju i semantiku, pri odabiru terminologije potrebno je u obzir uzeti i stvarnu jezičnu praksu. Živi je jezik odraz života, a ne konvencionalnih definicija i njemu bi se uvijek trebala dati prednost. Unutar hrvatske znanstvene zajednice sve se više počeo upotrebljavati prefiks kiber u krive svrhe, no ako popratimo upotrebu prefiksa cyber u drugim registrima, posebice u razgovornom stilu, novinarskom i informatičkom: on prevladava jer govornikova jezična intuicija prevaguje.

Važno je istaknuti da ako se već prihvaća neki strani pojam ili termin (jer nemamo svoj vlastiti) treba izabrati onaj naziv koji je nastao na samom izvoru. A izvor je SAD i cyber, a ne kiber. Taj se pojam upotrebljava na čitavom engleskom govornom području, on nije nastao u antičkoj Grčkoj, niti u Sloveniji, Njemačkoj ni Rusiji, nastao je u SAD-u kao izvoru najvećeg broja tehnoloških izuma koji su omogućili formiranje umreženog društva.

Riječ cyber danas se u engleskom jeziku osamostalila, tj. iz prefiksoida je postala pridjevom sa značenjem ,posjedovanje svojstva onoga na mreži“. Iz tog razloga u engleskom originalu možemo uočiti da se spojnica nikada ne upotrebljava. Ipak, u hrvatskom je jeziku možemo zadržati iako postoje brojni primjeri (npr. cyberfeminizam, sociologija cyber kulture, cyber prostor, cyber sigurnost, cyber kriminal i td.) u kojima se ne upotrebljava. 
Da zaključimo, temelj zaštite našeg jezika trebalo bi biti čuvanje od zaborava, pravilna upotreba domaćih riječi i bogaćenje leksika, a ne nepotrebno odbacivanje stranih termina ili umjetno osmišljanje domaćih termina i nametanje njihove upotrebe u cilju konvencionalne čistoće jezika.

\section{2. Pragmatika i analiza diskursa cyber-prostora}

Shvaćena kao njezin ogranak, cyber-pragmatika bila bi podređena pragmatici, tj. pragmalingvistici u klasičnom smislu. Samim time nameće se pitanje što nam neke od standardnih tema, teorija i metoda pragmatike mogu pružiti pri analizi diskursa cyber-prostora.

Pragmatika je lingvistička disciplina koja proučava značenja iskaza u realnim situacijama, bavi se jezikom kao komunikacijskim sustavom, naglasak stavlja na ciljeve razgovora te na značenje ne gleda kao na apstrakciju, pri čemu se u obzir uzimaju interpretacija i kontekst. Drugim riječima, za pragmatku je relevantno djelovanje jezikom, njegova upotreba, procesi zaključivanja (o kontekstu i sadržaju razgovora) i razumijevanje s obzirom na namjere govornika. Osnovne odlike pragmatike prema Leechu (1983: 5) jesu sljedeće:

1. značenje razlikuje od interpretacije,

2. vodi se retoričkim principima (poput Griceovih maksima (1980: 55-67)),

3. retorički principi motivirani su ciljevima razgovora,

4. povezuje smisao iskaza s ilokucijskom snagom,

5. bavi se problemima do kojih dolazi prilikom upotrebe jezika, s posebnim naglaskom na interpretaciju značenja i formiranju smisla iskaza,

6. pragmatička su rješenja spomenutih problema funkcionalna, a ne formalna,

7. pragmatika je interpersonalna i tekstualna,

8. moguće ju je opisati s pomoću trajnih i neodređenih vrijednosti.

S pomoću pragmatike lingvistika je svoje područje proširila u domenu kontekstualiziranih jezičnih oblika i govornikova, situativnog značenja.

Kako nas podsjeća Levinson u svome preglednom djelu Pragmatics (1983), suvremena upotreba termina pragmatika potekla je iz četiriju izvora. Prvi izvor bila bi Morrisova podjela semiotike na tri područja istraživanja, od kojih je jedna pragmatika kao grana koja proučava 
odnose znakova i njihovih interpretatora. Nakon njega, slijedi Carnapova definicija pragmatike koja se također oslanja na prisutnost sudionika komunikacije pri analizi jezične produkcije. Treće područje kao izvorište suvremenog termina pragmatike seže iz proučavanja deiktičnih izraza (Montagueov članak Pragmatics o deiktičnim izrazima), dok bi posljednje bila angloamerička filozofija i lingvistika kasnih šezdesetih godina 20. stoljeća.

Definiranje pragmatike, osim iz navedenih povijesnih razloga, tj. raznolikih izvora, $\mathrm{i}$ raznovrsnosti područja i danas je ostalo kompleksnim pothvatom. No, s pomoću različitih definicija na koje se može naići u literaturi lako je uhvatiti osnovnu misao. Stoga pragmatika može biti:

- znanstvena disciplina koja proučava jezik u upotrebi,

- znanstvena disciplina koja nastoji objasniti jezične strukture referiranjem na nejezične pritiske i uzroke,

- proučavanje jezika iz funkcionalističke perspektive,

- (iz generativističke perspektive) pragmatika bi se trebala baviti izvedbom (performance), a ne jezičnom sposobnošću (competence),

- pragmatika se bavi aspektima značenja koje ne pokriva semantika, bavi se iskazima a ne rečenicama,

- znanost je koja proučava odnose između jezika i konteksta,

- (definirana ostenzivno) pragmatika je proučavanje deiksa, implikatura, presupozicija, govornih činova i strukture diskursa,

- disciplina koja se bavi jezičnim djelovanjem.

Iz navedenog je razvidno zašto i pragmatika u posve klasičnom smislu, uz poneke prilagodbe mediju interneta, posve odogovara kao teorijski pristup i metoda izučavanja komunikacije na mreži. Osnovni ciljevi pragmatike i cyber-pragmatike (kao njezina potpodručja) jednaki su: objasniti dijalektiku iskaza i konteksta u kojem su ti iskazi nastali, ne bismo li bolje shvatili oboje.

Nadalje, unutar lingvistike postoji viđenje pragmatike u mnogo užem smislu. Pri tome se pragmatika percipira kao pristup diskursnoj analizi ili proučavanju društvene interakcije. Prema takvom viđenju pragmatika bi bila sličnija sociolingvistici ili pak analizi diskursa, a ne toliko 
osnovnim jezikoslovnim disciplinama poput semantike ${ }^{30}$. S druge strane, javlja se sve veća potreba za integriranom teorijom jezične sposobnosti i jezične upotrebe jer je postalo jasno da se određeni fenomeni mogu objasniti samo kontekstualizacijom, da pragmatika pojednostavljuje logičku osnovu semantike, da postoji velika praznina između lingvističke teorije i prakse te da upotreba utječe na strukturu jezičnog sustava.

U ovome radu neće se obrađivati sve navedene velike pragmatičke teme, to bi prije svega bilo nemoguće, no problematiziranjem diskursne kohezije (i koherencije teksta) i diskursnih oznaka dotaknut ćemo se raznolikih teorija. Iako će primjeri biti suvremenije naravi, pokušat ćemo ih sagledati sa starih i novih motrišta. Zbog toga ćemo ovdje spomenuti Griceove konvencionalne implikature, teoriju govornih činova i problem ilokucijske snage, problem intencionalnosti, prihvatljivosti, informativnosti i situativnosti. Sve navedeno s dvama ciljevima: da bismo pokazali primijenjivost pragmatike u cyber-kontekstu i stekli nove uvide u dosad istraživani fenomen diskursnih oznaka.

Herbert Paul Grice u svojoj teoriji implikatura obrađuje nekoliko različitih vrsta implikatura i nudi nam svoje viđenje ljudske komunikacije kao racionalnog djelovanja prema zajedničkom cilju. Taj bi cilj bio razmjena informacija kao jednog od vidova suradnje, tj. principa kooperativnosti koji je navođen maksimama kvalitete, kvantitete, relacije i načina. Grice navodi da se ljudi na površinskoj razni ne pridržavaju kooperativnog principa i njegovih maksima (često su dvosmisleni, neiskreni, nedovoljno opsežni ili preopsežni i nerelevantni za temu razgovora), ali na nekoj općoj razini prepuštaju maksimama da vode pozadinsku namjeru prema željenoj ili ciljanoj interpretaciji iskaza. Jezikoslovno zanimanje za navedene maksime proizašlo je iz činjenice da one proizvode zaključke koji sežu onkraj doslovnog/aktualnog sadržaja rečenice, a ti su zaključci implikature. Implikature nisu semantički zaključci, već su zaključci zasnovani na specifičnim pretpostavkama o kooperativnoj prirodi obične verbalne interakcije. Konverzacijske su implikature vrsta implikatura koje proizlaze iz kršenja prethodno navedenih maksima. Njih je Grice detaljno obradio, no za problematiku diskursnih oznaka mnogo su relevantije tzv. konvencionalne implikature. Ova je vrsta implikatura konvencijom vezana za određeni izraz ili leksem. U svim četirima obilježjima razlikuju se od konverzacijskih implikatura, te stoga: nisu poništive (non-defeasable), odvojive su od iskaza (detachable), nisu

\footnotetext{
${ }^{30}$ Od stare grčke pa do modernih autora koji prvi put navode termin pragmatika (poput Morrisa) pragmatika je shvaćena kao jedna od triju osnovnih jezičnih disciplina. Riječ je o disciplini kojom se proučava način komuniciranja odnosa, djelovanja govornika prema slušaocu ili obrnuto, a što ne pokrivaju ni sintaksa ni semantika.
} 
izračunljive (non-calculable) i konvencionalne su. One nam prije svega služe za organizaciju gramatike jer predstavljaju leksičke jedinice koje je nemoguće testirati na istinitosne uvijete, no koje se referiraju na pragmatičke sastavnice značenja, neophodne za potpunu informaciju i smislenost iskaza. U ovu skupinu Grice ubraja velik broj deiktičnih izraza, od kojih su nama najzanimljiviji oni izrazi koji su kasnije prepoznati kao diskursne oznake: diskursne deikse (npr. međutim, štoviše, osim toga, u svakom slučaju, pa, ipak, nadalje, ali, oh, da) i socijalne deikse (npr. gospodin, frendica, buraz, hej, oi!). Naposljetku, čitava teorija implikatura izvrsno prikazuje povezanost strukture i funkcije, pri čemu diskursne oznake mogu biti shvaćene kao svojevrsne ograde maksima (maxim hedges) koje sudionike komunikacije upućuju prema suradnji. Kao što navodi Levinson (1983: 162-166) nije teško primijetiti da brojne retoričke figure (ironije, metafore, retorička pitanja) mogu steći konvencionalne indikatore i strukturalne korelacije. Naposljetku, odnos implikature i jezične strukture može se proučavati u sklopu domene jezične promjene (dijakronijska lingvistika), pri čemu obično dolazi do semantičkog pomaka ili pak gubitka pojedinih aspekata značenja. Iz ove se teorije nameću sljedeća pitanja: može li se točno odrediti trenutak kada implikature postaju konvencionalne ili je riječ o nekom postepenom procesu konvencionalizacije? Također, može li se i kako taj process dovesti u vezu s procesom pragmatikalizacije (gramatikalizacije dikskursnih funkcija)?

Na Griceovu se teoriju implikatura nastavlja Diane Blakemore (2002) u vlastitoj teoriji diskursnih oznaka. Autorica pri tome stavlja težište na kognitivne aspekte teorije relevantnosti, te doprinosi istraživanjima dijakronijske pragmatike.

Uz Gricea i teoriju implikatura, teorija govornih činova kao važan dio pragmatike također može doprinijeti analizi značenja i razvoja diskursnih oznaka. Jer, iako diskursne oznake ne utječu na istinitosne uvjete iskaza, one mijenjaju njegovu ilokucijsku snagu a sam pojam ilokucijske snage čini okosnicu teorije govornih činova.

Zadatak je teorije govornih činova objasniti pod kojim uvjetima i u kojem smislu određeni iskazi podrazumijevaju djelovanje. Samim time teorija govornih činova pruža konceptualni okvir za opisivanje i shvaćanje različitih vrsta jezičnog djelovanja. Da bi se to moglo postići, Austin (1976) je u svojem djelu How to do Things with Words predložio razlikovanje triju vrsta, odnosno glavnih sastavnica govornih činova:

1. Lokucijski činovi odnose se na proizvodnju niza zvukova sa značenjem, tj. na sam čin govorenja. 
2. Ilokucijski su činovi činovi govorenja kojima se djeluje, a mogu se ostvariti upotrebom performativnih glagola poput: savjetovati, narediti, imenovati, obećati, izjaviti, pitati, zahvaliti, prosvjedovati; korištenim u prvom licu jednine ili množine prezenta.

3. Perlokucijski su činovi oni koji imaju izravan utjecaj na nečije misli, osjećaje i buduća djelovanja; primjerice čin uvjeravanja, sugeriranja, nagovaranja, obećanja i zbunjivanja.

Spomenute definicije uključuju izraze psiholoških stanja (zahvaljivanje, ispričavanje) i društvenih činova poput utjecaja na ponašanje drugih ljudi (upozoravanje, naređivanje) ili sklapanja ugovora (npr. obećavanje ili imenovanje). Govornici mogu izvoditi govorne činove na neeksplicitan način: nemaju svi iskazi sredstva za ukazivanje na ilokucijsku snagu (Stubbs 1983: 153). Upotreba performativnih glagola ovisi o formalnosti konteksta te o izraženom naglasku ili funkciji iskaza pri poricanju prethodnog iskaza. Ako ilokucijska snaga iskaza nije eksplicitna, uvijek ju je moguće učiniti takvom s pomoću performativnog glagola (Ibid. 157).

Searle je razvio svoju inačicu teorije govornih činova te u svome djelu Speech Acts: An Essay in the Philosophy of Language govori o četirima vrstama dijelova govornih činova (1980: 2325):

1. iskazivanje riječi (utterance acts),

2. referencija i predikacija, tj. tvrdnje (propositional acts) - semantički dio značenja,

3. izjavljivanje, ispitivanje, zapovijedanje, obećavanje i td. (ilokucijski činovi) pragmatički dio značenja/smisla/odnosa,

4. perlokucijski činovi.

Nadalje, autor razrađuje problem ilokucijskih činova ${ }^{31}$ te ih dijeli u pet osnovnih kategorija:

1. asertivi (assertives); činovi kojima se nešto tvrdi, primjerice: prijedlozi, hvalisanja, prigovaranja, izjave, priopćavanja, objašnjenja, opisi,

2. direktivi (directives); činovi kojima se nastoji utjecati na djelovanje ili stanje slušatelja, npr.: naredbe, zapovijedi, zahtjevi, savjeti i prijedlozi,

3. komisivi (commissives); činovi obvezivanja, npr.: obećanja, zavjeti, ponude,

4. ekspresivi (expressives); činovi s pomoću kojih nastojimo izraziti naše unutarnje, psihološko stanje, npr.: zahvaljivanje, čestitanje, opraštanje, optuživanje, pohvale, izražavanje sućuti,

\footnotetext{
${ }^{31}$ Prijevod originalnog Searleova nazivlja ilokucijskih činova na hrvatski jezik, preuzet je iz knjige Jezik $i$ djelovanje profesora Milorada Pupovca, dr. sc.
} 
5. deklarativi (declarations); činovi koji ovise o nejezičnim konvencijama i zahtijevaju primjereno podudaranje iskazanog sadržaja i stvarnosti, npr.: odrješenje, odricanje, krštenje, imenovanje, izopćavanje, ugovaranje, osuđivanje i td.

S obzirom na to da je ilokucijska snaga jedini aspekt značenja koji preostaje diskursnim oznakama, upravo to pragmatičko značenje koje ona tvori bit će nam od iznimne važnosti: značenje koje je uširoko konstruirano, koje se ne može svesti na uvjete istinitosti. Ilokucijska snaga stoga sačinjava aspekt značenja koji neki nazivaju proceduralnim (Blakemore), koji ne pokriva istinitosno-uvjetovana semantika, već ono koje se objašnjava uvjetima sretne/uspješne uporabe (felicity conditions) i uvjetima racionalnosti (cooperative principle).

Primjer 2: Modificiranje ilokucijske snage govornih činova (direktiva) s pomoću diskursnih oznaka na početku i na kraju iskaza. ${ }^{32}$ Originalni prikaz razgovora dostupan je u prilozima (prilog 2).

J: Je 1 stiglo??

$\mathbf{J}$ : Mozes dodat pored imena u zagradu kraticu (ACME)

J: Dodaj kraticu

J: : $:$

J: No? Jesio dobio??

T: Idem chekirat, imao sam posla

J: Ajd cekiraj, stavi ACME i javi plz

Naposljetku, uvodeći neke od velikih imena i teorija pragmatike u ovaj rad, još bismo se osvrnuli na nekoliko neizostavnih pragmatičkih koncepata, iznimno relevantnih za studiju diskursnih oznaka: problem intencionalnosti, prihvatljivosti, informativnosti i situativnosti. Iako ćemo se vratiti na neke od kriterija tekstualnosti, ponajprije na problematiku tekstne kohezivnosti i koherentnosti u kojoj diskursne oznake igraju veliku ulogu, sada bismo se osvrnuli na prethodno navedena, kako tekstna, tako i diskursna obilježja komunikacije.

Intencionalnost $\mathrm{t}^{33}$ se kao kategorija odnosi na govornika i njegovu namjeru da $\mathrm{u}$ iskaz(ima) ostvari vlastiti komunikacijski cilj. Pri tome je svakako potrebna suradnja među sudionicima komunikacijskog procesa, a tu se fokus pomiče s govornika na sugovornika, tj. na primatelja poruke i na kriterije prihvatljivosti govorne radnje (čina). Neki diskurs ili iskaz može biti

\footnotetext{
${ }^{32}$ Zelenom su bojom naznačene DO-e, a crvenom direktivi. DO-a ajd služi kao pojačivač ilokucijske snage, dok DO-a kojom se zatvara iskaz, u vidu kratice pls (od engl. please) služi kao ublaživač izravno upućenih zahtjeva. U prikazanom odsječku razgovora također je vidljiva gradacija u ilokucijskoj snazi koja kreće od direktiva kao zahtjeva (možeš dodat), da bi u idućem iskazu poprimio oblik naredbe (dodaj) i na kraju završio „pojačan“ diskursnom oznakom ajd i nizanjem dodatnih direktiva (čekiraj, stavi, javi).

${ }^{33}$ Shvaćena u Griceovom smislu.
} 
prihvatljiv ili ne u više različitih aspekata: po pitanju smislenosti (kohezivnost), strukturiranosti (koherentnost), sociokulturne prihvaćenosti (tabu), ideološko-političke opredijeljenosti (stav i svrha iskazivanja) itd. Nadalje, informativnost se odnosi na količinu novih i već poznatih informacija u diskursu, dok nas situativnost upućuje na važnost vanjezičnog konteksta. Sve navedeno (posebno u mediju kojem nedostaje potpuni kontekst komunikacijskog procesa) može biti modificirano, upravljano i određeno uporabom diskursnih oznaka. One primjerice mogu prenijeti namjeru raslojavanjem i stupnjevanjem značenja, prenošenjem stava i emocije (ilokucijska snaga). Govorimo li o prihvatljivosti, mogu „kupiti” vrijeme za razmišljanje ili iskazati potrebu za više/manje informacija, također mogu na pristojan način implicirati neprihvaćanje (Politeness Principle, Leech 1983). Naposljetku, diskursne oznake u vidu deiktičnih izraza mogu situirati tj. kontekstualizirati diskurs.

Opredjeljenje za pragmatiku kao jedan od pristupa koji će biti upotrebljen u analizi koja slijedi proizlazi iz nekoliko razloga koji su se već mogli iščitati pod ovim podnaslovom. Ovdje ćemo ih sažeti pod zajedničkim nazivnikom težnje ka kvalitetnijoj analizi, u vidu interdisciplinarnog pristupa. Stoga, pragmatika analizu cyber-diskursa obogaćuje uvidom u:

- globalne strukture cyber-diskursa,

- postizanje instrumentalnih ciljeva u cyber-komunikaciji,

- postizanje relacijskih ciljeva cyber-komunikaciji,

- načine djelovanja (izvršenja akcija) s pomoću iskaza,

- značaj konteksta za interpretaciju iskaza.

Na taj se način njome otkrivaju novi problemi i njihova rješenja unutar konteksta razmjene instant poruka. 


\section{3. Konverzacijska analiza i cyber-komunikacija}

Uz klasičnu pragmatiku, pri analizi komunikacije na mreži od iznimne se koristi pokazala i konverzacijska analiza. Konverzacijska analiza (odnosno $\mathrm{CA}^{34}$ od engl. Conversation Analysis) disciplina je koja se bavi analizom razgovora kao strukturiranog društvenog događaja, tj. proučava jezik u interakciji (Liddicoat 2007: 2). Pristupajući diskursu, razmatra načine na koje sudionici razgovora nastoje riješiti organizacijske probleme do kojih dolazi u konverzaciji (Schiffrin 1994: 273).

S obzirom na prirodu proučavanog korpusa: razmjene instant poruka koje se najčešće odvijaju u dijaloškoj formi i obilježjima vrlo su bliske razgovorima koji se odvijaju pri komuniciranju licem u lice, konverzacijska se analiza doima kao logičan izbor teorije i metode. Ipak, metoda će biti prilagođena mediju interneta zbog nedostatka zajedničkog fizičkog konteksta pri cyber-komunikaciji i nekih novih oblika jezičnog i parajezičnog ponašanja.

Kao pristup proučavanju jezika i društvenog djelovanja pojavila se u šezdesetim godinama 20. stoljeća, unutar etnometodološke tradicije u sociologiji, a razvio ju je Harold Garfinkel (2003). Etnometodologija je krajnje empirijski usmjerena disciplina te je proizvela mnoštvo analitičkih radova poput: proučavanja telefonskih razgovora, snalaženja na mapama, analiza novinskih izvještaja, političkih govora i sl. Uz upotrebu klasične sociološke metodologije za potrebe vlastitih istraživanja, etnometodologija je razvila i vlastite alate od kojih su zasigurno najpoznatiji eksperimenti prekida i konverzacijska analiza, koja je postala glavnom podgranom etnometodologije. Do spomenute popularnosti i razvoja konverzacijske analize unutar etnometodologije došlo je zbog osnovnog predmeta proučavanja same etnometodologije: ljudskog ponašanja u društvu, čijom se specifičnom podvrstom (konverzacijom) bavi konverzacijska analiza. CA se zasniva na pretpostavci da je konverzacija temelj svih drugih ponašanja osobe te da konverzacija predstavlja najprirodniji oblik interakcije. Plodnom tlu za razvoj konverzacijske analize unutar etnometodologije također je pogodovala etnometodološka težnja ka proučavanju opažljivih aktivnosti društvenog života ljudi i bavljenjem malim fenomenima s pomoću kojih se nastoji doći do većeg razumijevanja ljudskih postupaka. Inovacija koju su uvele etnometodologija i konverzacijska analiza jest davanje nove uloge

\footnotetext{
${ }^{34} \mathrm{U}$ tekstu ćemo se koristiti engleskom skraćenicom za konverzacijsku analizu CA zbog njezine međunarodne prepoznatljivosti i uvriježenosti u široj akademskoj zajednici.
} 
svakodnevnom govoru, koji sada sam postaje predmetom analize, a ne pukim resursom kao što je to nekada bio, jer govor je jedan od načina na koje se realizira društveni život.

Etnometodologija društvenu stvarnost shvaća na nekoliko sljedećih načina (Ritzer 1997: 255-256):

1. kao refleksivnu djelatnost, jer svi smo mi uključeni u proces konstruiranja socijalne stvarnosti, iako smo tih procesa vrlo rijetko svjesni,

2. kao koherentnu cjelinu znanja, što je vidljivo iz činjenice da ljudi organiziraju svijet u koherentne stvarnosti,

3. kao interaktivnu djelatnost, jer njezino postojanje ovisi o recipročnim interakcijama i o socijalnoj konstrukciji stvarnosti od sudionika,

4. kao fragilnu, a ne čvrstu strukturu,

5. kao permeabilnu stvarnost, što je vidljivo u činjenici da ljudi žive u raznolikosti društvenih svjetova i kreću se od jedne prema drugoj stvarnosti.

Naposljetku, bilo bi nemarno izostaviti neke od osnovnih pojmova etnometodologije koje navodi Ritzer (ibid. 256-257):

- Prikazivanje - proces kojim akteri uobličuju, analiziraju, opisuju, tipiziraju, kritiziraju i idealiziraju svijet. Sve se to ostvaruje s pomoću ljudskih iskaza, što je još jedan razlog etnometodološke zaokupljenosti konverzacijskom analizom.

- Indeksnost - odnosi se na činjenicu da svi iskazi i djelovanja moraju biti interpretirani u okvirima specifičnih konteksta (jezičnih i vanjezičnih).

- Princip „i tako dalje“ - govori da sve situacije uključuju nekompletne aspekte koje učesnici moraju popuniti.

- Dokumentarna metoda - pokušaj je identifikacije prikrivenog obrasca iza serija određenih pojava.

- Prirodni jezik - nije identičan lingvističkim kategorijama, već se odnosi na osnovne strukture interakcije govornik/slušatelj, što je osnovni interes konverzacijske analize. 
Naglasak na proučavanje stvarnih primjera društvene interakcije stavio je već spomenuti Erving Goffman, čime je doprinio daljnjem razvoju ove discipline. Goffman je isticao da proučavanje razgovora nije isključivo predmet lingvistike te da je uz opis jezika u obzir potrebno uzeti interakciju s vlastitim sustavom pravila i struktura (Liddicoat 2007: 4). Početkom sedamdesetih godina 20. stoljeća, posredstom radova Harveya Sacksa, Emmanuela A. Schegloffa i Gaila Jeffersona, CA je počela izlaziti iz okvira sociologije. Danas se upotrebljava u okvirima sociologije, antropologije, lingvistike, komunikologije i psihologije, a utjecala je na interakcijsku sociolingvistiku, analizu diskursa i diskurzivnu psihologiju.

S obzirom na shvaćanje pojma diskursa i analizu diskursa (u širem smislu) konverzacijska se analiza može svrstati pod funkcionalističke pristupe diskursu iz nekoliko sljedećih razloga (Schiffrin 1994: 21-22):

1. Naglasak stavlja na analizu jezične upotrebe, umjesto na analizu jezičnog koda.

2. Pri analizi se na prvom mjestu nalaze drštveni odnosi, a ne referencija.

3. Jezik je shvaćen kao socijalni, a ne mentalni fenomen.

4. Na jezik se gleda kao na društvenu funkciju i posljedicu društvenog života, a ne kao na urođenu sposobnost i autonoman sustav.

5. Istaknuta je važnost jezičnog konteksta.

Cilj je konverzacijske analize da otkrije i opiše (uvijek prisutnu) uređenost razgovora (njegove pravilnosti i obrasce funkcioniranja), te da objasni i opiše sposobnosti govornika koji sudjeluju u razumljivoj društvenoj interakciji, pri čemu se u obzir obavezno uzima kontekst.

Da bi se konverzacijska analiza uspješno provela, potrebno je na umu imati barem tri sljedeće odlike analize:

1. Podaci za analizu moraju biti primjeri stvarnih razgovora u realnim kontekstima. CA se koristi metodom uzorkovanja u kojoj je svaki podatak pravi dio stvarnosti, a ne tvrdnja o istraživanoj stvarnosti.

2. Analitičari se nastoje služiti tzv. „nemotiviranim promatranjem“ (engl. unmotivated looking), tj. uzastopnim preslušavanjem snimki razgovora, da bi otkrili što se događa $s$ podacima, bez utjecaja već postojećih stavova o predmetu proučavanja. 
3. Moguće je proučavati jedan slučaj ili skupinu sličnih slučajeva.

Što se tiče kvantifikacije rezultata, u konverzacijskoj analizi to se čini upotrebom priloga (npr. često, obično, iznimno, tipično, redovito), a ne numerički (iskazivanjem frekventnosti, ukupnih iznosa, postotaka). Ovakva je kvantifikacija uobičajena i prikladna zbog velike ovisnosti analiziranih razgovora o kontekstu u kojem su se odvijali, a koji su ih učinili međusobno različitima. Kao posljedica takva pristupa analizi javljaju se određeni nedostaci, ali i prednosti karakteristični za kvalitativna istraživanja, poput:

- Nemogućnosti velikih generalizacija zbog analize malih i ciljanih uzoraka, no otvara se mogućnost dubinskog, detaljnog pristupa problemu.

- Nepostojanja standardiziranih instrumenata mjerenja osim samog istraživača, što vodi do potencijalne subjektivnosti i teške provjerljivosti rezultata. Ipak, naglašena je vještina interpretacije podataka koja može dovesti do neočekivanih spoznaja, te se ističe potreba za interdisciplinarnošću.

- S obzirom na to da se rezultati ne prikazuju numerički, oni gube na ilustrativnom, deskriptivnom i preglednom karakteru, no dobivaju sistematski i objasnidbeni karakter jer se podaci razvrstavaju u pojmovne kategorije.

Da bi se na sistematiziran način pristupilo konverzacijskoj analizi, ona se može provoditi zasebno na različitim mehanizmima s pomoću kojih se uređuju razgovori, a neki su od njih sljedeći: problem preuzimanja reda u govorenju/pisanju, praznine i preklapanja u razgovoru, bliski parovi, proširivanje i popravljanje razgovora.

Primjer 3: Diskursne oznake i mehanizmi uređivanja razgovora u CA okviru. ${ }^{35}$ Originalni prikaz razgovora nalazi se u prilozima (prilog 3).

T: Ok, New day, New numbers to be quested! Od joze mi treba broj, imas mozda?

J: o boze, vec sam mislila da saljes automatizirane poruke! Ono hello there, i just joined whatsapp $(-)$

J: Cek sekundu

J: E, to je bilo u starom mobu bit ce, ali javila sam mu se na fejs za broj, pa ti javim kad odgovori

J: osjecam se ko sekretarica!!

T: Thanx, zvao bi ga da vrti mjuzu $17 \mathrm{og}$, htio bi napravit pokret odmora

\footnotetext{
${ }^{35}$ Zelenom su bojom naznačene diskursne oznake. U prvom iskazu DO-a $o k$ upotrijebljena je za otvaranje razgovora, DO-a ono ima funkciju uvođenja primjera/parenteze/proširenja, te služi kao svojevrsni diskursni veznik. Uzvik E! ovdje je također dikursna oznaka koja naznačuje stav/emociju govornika, no također ima funkciju otvaranja iskaza. Zadržavanje reda u govorenju naznačeno je crvenom bojom i predstavlja vrlo specifičan element razmjene instant-poruka, jer je iskazan zbog manjka zajedničkog fizičkog konteksta.
} 
Zbog činjenice što CA proučava društvenu interakciju u vidu razgovora i uvelike se oslanja na kartakter konteksta koji sugovornici dijele, bit će ju zanimljivo primijeniti pri analiziranju razgovora koje određuje internet te stvara dosad neviđene kontekste. Konverzacijska analiza također pogoduje analizi računalno posredovanog diskursa u vidu IM-a iz još nekoliko razloga:

- U tradicionalnom se obliku CA bavi analizom transkribiranih razgovora, tj. jezika u upotrebi (pod što spada i razmjena instant poruka) u smislu prirodne interakcije. Tome pogoduje činjenica da je materijal za samu analizu lako dostupan u slučaju IM-a zbog postojanja dnevnika instant poruka koji predstavljaju izvorne zapise razgovora.

- Vlastitim instant porukama korisnici djeluju i pokazuju shvaćanje interakcije u kojoj sudjeluju, te njihova spomenuta djelovanja u vidu instant poruka stoje u određenom odnosu jedni prema drugima. CA će nam sa svojom perspektivom omogućiti pogled na organizaciju i međuodnose instant-poruke kao oblika djelovanja jezikom.

- CA ističe važnost jezičnog konteksta koji se u slučaju IM-a mijenja zbog specifičnog izvanjezičnog konteksta, te nam svojim pristupom može ukazati na odstupanja IM-a od komunikacije licem u lice. Ona nam otkriva probleme s kojima se susreću sudionici računalno posredovanih razgovora i načine na koje ih nastoje riješiti.

Uz prednosti, konverzacijska analiza naravno ima i određenih mana i pred njom se nalazi nekoliko zahtjeva za prilagodbom, tj. svojevrsnim ažuriranjem metode. Gotovo svi problemi s kojima se CA susreće u cyber-kontekstu izviru iz tekstnih i interakcijskih obilježja komunikacije na mreži. Problemi su sljedeći:

- $\quad$ sve je tekst na ekranu,

- $\quad$ serveri isporučuju tekst u cjelini, stoga nema simultane povratne sprege ni preuranjenog zaključivanja,

- $\quad$ poruke se miješaju,

- neki su iskazi iscjepkani,

- sudionci nisu nužno suprisutni pa je teško računati na interakcijsku povratnu spregu,

- različiti razgovori mogu se preklapati.

No, s pojavom novih izazova javljaju se i nova rješenja: tekstom se skrola (od engl. scroll), zbog nepostojanja simultane povratne sprege socijalne su norme labavije, linearni, 
dvodimenzionalni karakter razgovora zamijenjen je mrežnom strukturom, multimodalnošću i novim načinima nošenja s preprekama poput preklapanja, praznina i pogrešaka u razgovoru (npr. upotreba asteriska pri ispravcima).

\begin{tabular}{|l|l|}
\hline \multicolumn{2}{|l|}{ Tablica 2: Razlike metoda i ciljeva između pragmatike i CA pri analizi diskursa } \\
\hline PRAGMATIKA & KONVERZACIJSKA ANALIZA \\
\hline $\begin{array}{l}\text { S pomoću apstraktnih principa (npr. } \\
\text { Griceovih maksima) objašnjava specifične } \\
\text { iskaze: vodi se metodom deduktivnog } \\
\text { zaključivanja. }\end{array}$ & $\begin{array}{l}\text { Nastoji otkriti opće principe proučavajući } \\
\text { specifične obrasce u razgovorima (npr. } \\
\text { bliske parove): vodi se metodom } \\
\text { induktivnog zaključivanja. }\end{array}$ \\
\hline $\begin{array}{l}\text { Bavi se globalnim strukturama diskursa } \\
\text { (npr. organizacijom tema u razgovoru). }\end{array}$ & $\begin{array}{l}\text { Bavi se lokalnim strukturama diskursa } \\
\text { (npr. odnosima među redovima u } \\
\text { govorenju). }\end{array}$ \\
\hline $\begin{array}{l}\text { Na kontekst gleda kao na osnovni faktor } \\
\text { koji oblikuje značenje te naglasak stavlja } \\
\text { na iskustvo i interpretaciju iskaza. }\end{array}$ & $\begin{array}{l}\text { Kontekst shvaća etnometodološki: } \\
\text { indeksnost iskaza govori nam da njih } \\
\text { oblikuje kontekst, ali i da je kontekst } \\
\text { oblikovan iskazima. }\end{array}$ \\
\hline $\begin{array}{l}\text { Pokazuje kako se postižu instrumentalni } \\
\text { ciljevi komunikacije (načelo suradnje) te } \\
\text { kako se postižu odnosni ciljevi } \\
\text { komunikacije (načelo pristojnosti). }\end{array}$ & $\begin{array}{l}\text { Pokazuje organizacijske probleme u } \\
\text { razgovorima i njihova riješenja (npr. } \\
\text { praznine i preklapanja u razgovoru). }\end{array}$ \\
\hline $\begin{array}{l}\text { Pokazuje postizanje akcije iskazima } \\
\text { (teorija govornih činova). }\end{array}$ & $\begin{array}{l}\text { Pokazuje postizanje interakcije u vidu } \\
\text { razgovora. }\end{array}$ \\
\hline
\end{tabular}

Pragmatika kao i konverzacijska analiza (CA) kojom ćemo se koristiti pri analizi cyberdiskursa, veliku važnost pridaju utjecaju društva i konteksta. Ipak, one imaju drugačija polazišta i naglašavaju različite aspekte jezične upotrebe. Njihovi se pristupi međusobno nadopunjuju i time obogaćuju našu analizu, što prikazuju njihova obilježja navedena u tablici 2.

Kao što je naglašavano u prethodnim podnaslovima, ovi će pristupi biti prilagođeni cyber-kontekstu kao kontekstu istraživanja. Na kraju, tome će se pridodati analiza parajezika, tj. neverbalne komunikacije u cyber-svijetu. 


\section{4. Nevrbalna komunikacija i parajezik cyber-svijeta}

Jedno od osnovnih obilježja cyber-komunikacije, obiljě̌je je koje spominjemo od samog početka rada: karakteristika izostanka zajedničkog fizičkog konteksta. Drugo vrlo bitno obilježje bila bi tekstualnost koja još uvijek dominira ovom sferom komunikacije, kao i pretežno oslanjanje na vizualni kanal. Upravo iz navedenih razloga, neverbalna komunikacija i parajezik u cyber-diskursu funkcioniraju na nešto drugačiji način.

U pragmatičkom smislu, virtualni se razgovori u svojoj osnovnoj strukturi ne razlikuju mnogo od razgovora licem u lice. Oni (jednako kao i njihovi nemedijatizirani prethodnici) u obzir moraju uzimati govornikovo značenje, namjeru, interpretaciju i sustav zaključivanja. Kao i u bilo kojem razgovoru, sudionici raspolažu različitim sredstvima kodiranja poruke. Također, sudionici razgovora pretpostavljaju da su njihovi sugovornici upoznati s konvencijama tzv. „oralizacije teksta” (npr. skraćenice i emotikoni), kako je naziva Yus (2011: 162-164), i s konvencijama aplikacije kojom se koriste (npr. kako slati privatne poruke, mijenjati statuse, stavljati tzv. hashtagove i slično). Drugim riječima, razmjene instant-poruka tj. bilo koji oblik cyber-razgovora zahtijeva određen stupanj cyber-pismenosti.

U komunikaciji koja se u osnovi bazira na tekstu zapravo ne postoji istinska simultanost razmjene, kao što ne postoji simultanost između korisnikova verbalnog i neverbalnog ponašanja. Iz tog razloga Reid (1994: 21-32) zaključuje da korisnik koji tipka poruku također mora natipkati i svoje parajezično ponašanje. Jednako tako, čitatelj poruke mora zamisliti i interpretirati značenje tog napisanog neverbalnog ponašanja. Upravo taj spomenuti nedostatak simultanosti, tj. činjenica da se verbalna i neverbalna komunikacija ne preklapaju niti se javljaju istovremeno, posljedica je toga što se tipkati može jedino u slijedu (linearni karakter pisma).

O pragmatičkoj kategoriji intencionalnosti treba reći da u cyber-razgovorima rijetko kada izostaje. Ovdje gotovo da nema nenamjeravanog neverbalnog ponašanja. $\mathrm{S}$ druge strane, intencionalno prenošenje neverbalih informacija urodilo je specifičnim diskursnim, semiološkim i jezičnim oblicima kao što su emojis i emotikoni te svojevrsni oblik didaskalija (stage directions) koje riječima opisuju neku radnju izvođenu za vrijeme komunikacijskog događaja. 
John Carey (1980) bio je jedan od pionira paralingvistike računalno posredovane komunikacije. Izdvojio je i definirao osnovna oblježja neverbalne komunikacije na mreži, a u nju je ubrojao sljedeće (primjeri su preuzeti iz našeg korpusa):

i. $\quad$ vokalizirano pisanje (engl. vocal spelling), npr. pliiiiiz [pli:z]

ii. Zamjene/surogati - leksički (u vidu didaskalija), naprimjer: vozim!!! ubijaš me - vokalni (imitativi), naprimjer: hmmmmm [xə:m]

iii. prostorni razmještaj - upotreba razmaka između pojedinih slova unutar jedne riječi ne bi li se nešto „,islovkalo” tj. naglasilo, slaganje slova u sliku ili nešto drugo. Na primjer ne želim ići

iv. manipuliranje gramatičkim oznakama - u smislu pretjerane uporabe interpunkcijskih znakova, neobične uporabe velikih slova za iskazivanje deranja/glasnoće ili uporabe trotočja za iskazivanje šutnje. Na primjer: ZAŠTO?!?!

v. negativna obilježja - odnose se na tekstna obilježja koja ovdje izostaju, poput neispravljanja pogrešaka u tipkanju.

Osim toga, zbog činjenice da je za tipkanje potrebno više vremena nego za govorenje, cyberkomunikacija, posebice ona sinkronog tipa poput virtualnih razgovora, teži prema ekonomizaciji izraza. Često se stoga možemo susresti sa skraćenicama, akronimima, elipsama, gotovo „natukničkim” govorom, ali i rebusima poput $l 8 r^{36}$ od $l+e i g h t+e r$, (kojih gotovo nema u hrvatskom, no oni engleski se često upotrebljavaju kao internacionalizmi).

Kako uviđa i sam Yus (2011: 179), ovakve inovacije u diskursu pomažu primatelju pri prepoznavanju propozicijskog stava koji se nalazi u pozadini strukture poruke. Drugim riječima, uloga je navedenih didaskalija, imitativa i izmijenjene grafije u osnovi proceduralna i predstavlja glavni alat cyber-diskursa jer osigurava željenu interpretaciju poruke. Kao što smo već rekli, upravo je ta proceduralnost temeljno funkcionalno obilježje diskursnih oznaka, stoga ne čudi da se često baš zapisani parajezik oblači u njihovo ruho.

\footnotetext{
${ }^{36} \mathrm{U}$ prijevodu na hrvatski: kasnije.
} 
Primjer 4: Korištenje imitativa u funkciji diskursne oznake kojom se iskazuje emotivno stanje/stav prema situaciji i zatvara se iskaz. Prikaz izvornog razgovora dostupan je u prilozima (prilog 4).

JS: Hjaooo tri sata za tri palete i to na pol potrgane... kmee

$\mathbf{J}$ : Nis, bude bila osb il tak nes, mozemo danas popodne u neki od tih ducana

JS: Ne brini

Prethodnu tvrdnju u neku ruku podupire i rad autorice Knas iz 2009. godine. U studiji Read my Voice: Expressing Silence and Sound in SMS autorica obrađuje načine na koje se korisnici nose s tehnologijom kako bi zabilježili audio obilježja komunikacije pismom. Knas ovdje uvodi pojam tzv. tekstnih oruđa koje dijeli na tri kategorije: šutnju, popunjivače pauza (fillers) i fonetikone. U samim primjerima koje autorica navodi: trotočja, spojnice i razmake za šutnju, tj. elipsu, imitative za popunjivače pauza u diskursu (npr. hmmm) i grafemske prikaze glasovnih obilježja, tj. fonetikone (npr. Š T O?!), možemo zaključiti da je riječ o parajeziku, ali i diskursnim oznakama. Zaključak o parajeziku ovdje je poprilično očit, no što je s diskursnim oznakama? Knas smatra da navedena tekstna oruđa igraju važnu ulogu u percepciji fizičke blizine, no tome bismo sami nadodali da su ona također relevantna kako za ostvarenje socijalne kohezivnosti, tako i za ostvarenje diskursne kohezivnosti. Drugim riječima, šutnja tj. nepopunjene pauze u zapisanom obliku imaju funkciju svojevrsne ograde, granice među iskazima (tzv. hedging), ali ona istovremeno može prenositi (proceduralno) značenje.

Primjer 5: Primjer diskursnih oznaka u vidu ograda, tj. razdvajanja različitih iskaza s pomoću nepopunjenih pauza/šutnje $u$ vidu trotočja. Originalni prikaz isječka razgovora dostupan je $u$ prilozima (prilog 5).

JS: Pa ne znam, sad je bas upeklo.. nije za ic nigdje... ocemo kasnije popodne... idem oprat sudje i ususavat malo sad

J: Ok, mozemo kasnije, $5 / 6$ !

Popunjivači diskursa, kao svojevrsna podvrsta diskursnih oznaka popunjavaju redundantne pauze, označuju procesiranje poruke, nesigurnost ili pak zadržavanje reda u govorenju. 
Fonetikoni pak prenose stavove, emocije, intonaciju i sl., modificirajući time značenje, tj. interepretaciju iskaza, što ponovo koincidira s kategorijom diskursnih oznaka.

Primjer 6: Diskursna oznaka u vidu popunjene pauze (engl. filler): hmmm. Originalni prikaz isječka razgovora dostupan je prilozima (prilog 6).

J: Ja dodjem nekad sutra predvecer! Oces me docekat s vecerom? :) ;)

T: Hmmm, ak ne odem u Milano

\subsubsection{Zapisana šutnja}

U kontekst cyber-komunikacije i problem manjka klasične neverbalne komunikacije te parajezika na mreži izvrsno se uklapa i tema šutnje. Šutnja, iako sačinjava neizostavan dio komunikacije, dugo je izmicala iz vidokruga lingvista. Pretpostavlja se da je tomu tako zbog centralnosti gramatičke tradicije u lingvistici, dominacije analize pisanoga teksta pa i zbog strukturalističkog nasljeđa (orijentiranog na sistem, a ne toliko na njegove ostvaraje poput govora, u kojem se šutnja najviše ističe). S druge strane, ako bi se jezikoslovci bavili šutnjom, često bi bila definirana negativno: kao pozadina za govor.

S pojavom digitalnih medija i razvojem cyber-komunikacije koja je proizvela tzv. oralizirani tekst ta ista šutnja sada biva zapisanom, tj. zabilježenom, i samim time malo lakše uhvatljivom. Ovdje ćemo joj se nastojati približiti s pomoću aspekta pragmatike i diskursnih oznaka jer pretpostavljamo njihovu povezanost, posebice na dijakronijskoj razini.

Iako proučavanje šutnje zaista nije opsežno, ipak je vrijedno izdvojiti nekoliko imena i radova koji bi pokrili ovu temu. Deborah Tannen i Muriel Saville-Troike (1985) izdale su zbornik radova u njihovu uredništvu, pod nazivom Perspectives on Silence. Sam zbornik podijelile su na pet tematskih dijelova, od kojih prvi smiješta šutnju u integriranu teoriju komunikacije, a drugi dio šutnju proučava iz psihološke i etnografske perspektive pauziranja. U trećem se dijelu nekolicina autora bavi raznolikim značenjima i upotrebama šutnje (sociopragmatički), dok četvrti dio šutnju stavlja u međukulturalni kontekst. Naposljetku, šutnja se obrađuje u sklopu temata neverbalne komunikacije, iznimno korisnim za naš tip analize. 
U desetljeću koje je uslijedilo, točnije 1993. godine, Adam Jaworski izdao je vlastitu knjigu na temu šutnje: The Power of Silence: Social and Pragmatic Perspectives. U njoj je autor pokušao dati pregled dosadašnjih viđenja i definiranja šutnje, smjestio ju je u područje komunikacijskih studija, nastojao ju je usporediti s govorom, uspostaviti njezinu pragmatiku te pružiti neke primjere kritičke analize diskursa čije je jedno od osnovnih oruđa šutnja. Autor knjigu završava promišljanjem o estetskim vrijednostima šutnje te raznolikim medijima i semiološkim sustavima kojima se ona može prenositi.

Nekoliko godina kasnije, 1998., Dennis Kurzon objavljuje svoju knjigu naslova Discourse of Silence, pri čemu objašnjava dva moguća načina na koja se može shvatiti njegov termn „diskurs šutnje”. S jedne strane, autor ističe da to može biti modalni pristup šutnji koji obuhvaća gramatičku, semantičku i pragmatičku analizu, uključujući raspravu o šutnji kao integralnom dijelu razgovora. $S$ druge strane, on navodi da je diskurs šutnje ujedno i sintaktička perspektiva prijelaznosti šutnje, pri čemu agens ima moć nametanja šutnje drugima (1998: 3). Za razliku od prethodnih autora, Kurzon je ovdje zauzeo semiološko polazište. Zanimljivo je da se ono više oslikava u samoj prezentaciji teorije u prvim dvama poglavljima, a manje u samoj analizi primjera, u kojoj mnogo sličnosti dijeli sa sociolingvističkim, pragmatičkim, etnografskim i kulturno-antropološkim pristupima. To se izvrsno ocrtava u njegovoj podjeli šutnje na četiri moguća tipa: a) konverzacijsku šutnju (intencionalnu kao govorni čin, neintencionalnu kao posljedicu kognitivnog procesiranja), b) tematsku šutnju (kao izbjegavanje teme, ono neizrečeno što svi znaju), c) tekstnu šutnju (odnosi se na čitanje u tišini) i d) situacijsku šutnju (odnosi se na institucionalizirane oblike šutnje, kada naiđe netko nepoznat ili neželjen ili kada nam nešto odvuče pažnju pa zašutimo).

Uz prethodno navedene autore i njihovo viđenje šutnje ovdje je još potrebno istaknuti Michal Ephratt, profesoricu sa Sveučilišta u Haifi, koja se u značajnoj mjeri posvetila ovoj problematici. Autorica temi šutnje pristupa iz funkcionalističke jezikoslovne perspektive (utjecaj Jakobsona i Praškog lingvističkog kruga vidljiv je u radu The functions of silence, 2008) te unutar okvira klasične pragmatike (primjerice utjecaj Gricea u članku iz 2012 "We try harder - Silence and Grice's cooperative principle, maxims and implicatures”). Relevantnost šutnje Ephratt oslikava na primjerima triju velikih nerješenih problema ljudske komunikacije i njihovih odnosa prema šutnji (2011: 2298). Prvi se problem odnosi na postotak verbalne sastavnice diskursa (među odraslima, u komunikaciji licem u lice) koja ne prelazi $35 \%$. Autorica pita što je s ostalih $65 \%$ komunikacije? Drugo se pitanje nadovezuje na prethodno, a zanima se za neverbalne aspekte komunikacije. Postavlja se pitanje koji su to ostali konstituenti 
komunikacije uz verbalnu. Naposljetku, Ephratt ističe da treba proučavati odnos neverbalnog i verbalnog aspekta komunikacije jer su u stvarnosti oni isprepleteni, a ne izolirani i odvojeni jedan od drugoga.

Kao i za problematiku cyber-komunikacije, i za šutnju je relevantno razložiti neverbalnu komunikaciju s obzirom na osjetila, kanale percepcije ili fizičke organe. Pri tome pomaže raslojavanje neverbalnog na kineziku, proksemiku, parajezik i kronemiku. Ovdje je također iznimno zanimljiva i Lyonsova shema odnosa između verbalne i neverbalne komunikacije, koja za centar uzima jezik, prikazana u grafičkom prikazu 6.

Iako će nama svi spomenuti elementi biti od velike koristi pri proučavanju diskursnih oznaka, u ovom je podnaslovu naglasak stavljen na parajezičnu komponentu, u sklopu koje se javlja i fenomen tzv. dijalogične šutnje.

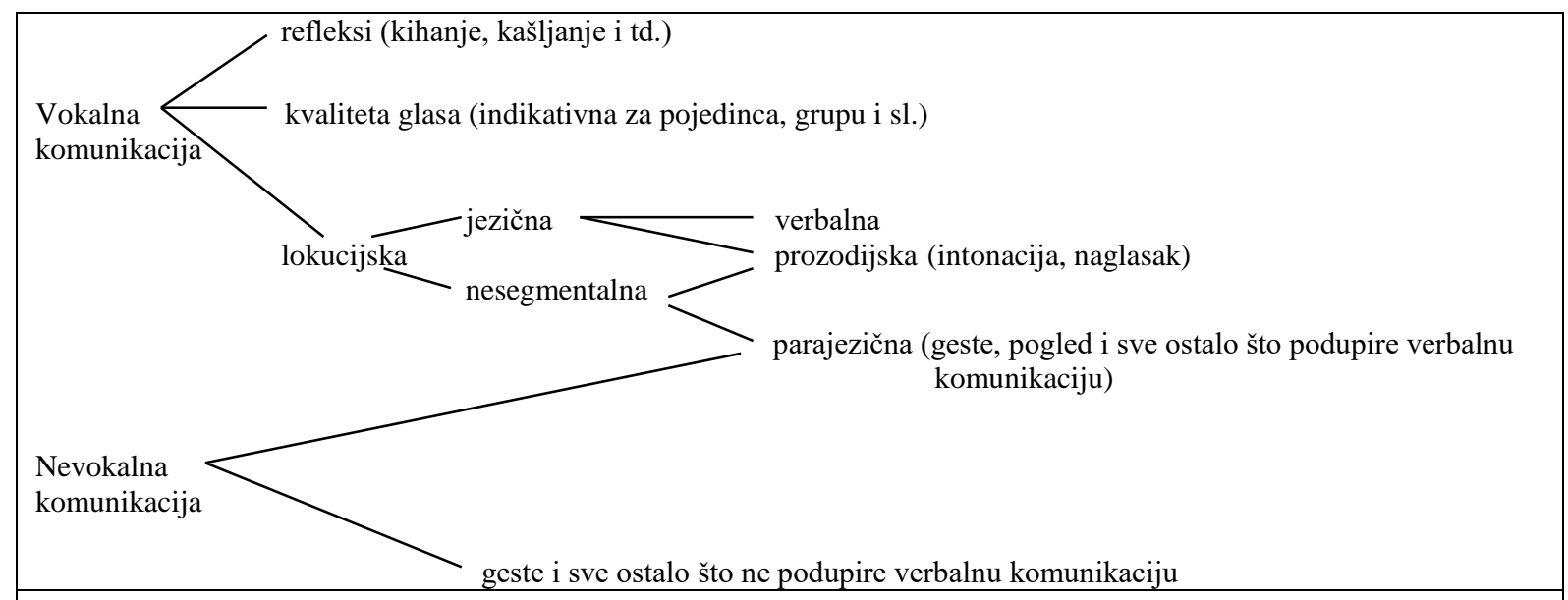

Grafički prikaz 5: Odnosi između verbalne i neverbalne komuniacije (Lyons, 1972)

Za razliku od prethodnih istraživanja koja su polazila od lingvistike i jezika kao središta ljudske komunikacijske djelatnosti, u sklopu šireg područja neverbalne komunikacije, ističe se Fernando Poyatos (2002). Autor šutnju smješta u klasu tzv. alternanata, u sklopu (podsustava) parajezika. Pri tome navodi brojne primjere u kojima tihe alternante razgraničavaju elemente govora u vidu punktuacija (speech markers), ili služe za otvaranje reda u govorenju (turn openings), ili se koriste zbog unutarnjih psiholingvističkih potreba (leksičko pretraživanje, oklijevanje, samo-popravljanje), ili kao posljedica emotivnog stresa (tuga, sreća). Sve navedene karakteristike klase alternanata koju osmišlja Poyatos zapravo odgovaraju onima klasi 
diskursnih oznaka. To je stoga još jedna od poveznica između DO-a, šutnje, diskursnih popunjivača i imitativa. Naposljetku, ovaj se autor ističe i svojim doprinosom tipologiji šutnje. Poyatos naime uz proučavanje šutnje unutar parajezika (u vidu kategorije alternanti) prepoznaje šutnju i tišinu (stillness) kao dodatne, neovisne kategorije uz trostruku strukturu komunikacije koja se sastoji od jezika, parajezika i kinezike.

Iako se u svim navedenim studijama (od koji je Knas iznimka) autori bave isključivo šutnjom u govoru, tj. u komunikaciji licem u lice, ili različitim žanrovima govorene komunikacije poput intervjua i predavanja, zanimljivo je vidjeti kako se ona enkodira u pisanom govoru cybersvijeta (najčešće u obliku trotočja), ali i zašto, kada i gdje se pojavljuje. No prije same analize važno je ukazati na to da će se ovaj rad baviti isključivo šutnjom unutar poruka, a ne između poruka, bavit ćemo se različitim manifestacijama/enkodiranjem šutnje (upotrebom punktuacije, praznina/razmaka, pisanim opisima šutnje/tišine), predšutnjom i postšutnjom (Knas 2009: 4) te raznolikim komunikacijskim funkcijama šutnje (Ephratt 2008). Na posljetku, šutnju se može tretirati kao indeks (parajezična razina), kao simbol (jezična razina) i kao ikonu (izvanjezična razina), što će se razjasniti u poglavlju 6 koje tematizira sociosemiotičke aspekte cyberkomunikacije.

Naposljetku, šutnju ćemo staviti u opreku spram zvuka koji (kao i šutnja) može biti dio komunikacije, ali i ne mora. S obzirom na to da u računalno posredovanoj komunikaciji zvuk izostaje jednako kao i šutnja, korisnici su s vremenom razvili tekstualne reprezentacije zvučnih informacija za prozodiju, smijeh i druge nejezične zvukove. Gotovo kao u stripu, česti su onomatopejski izrazi, tj. imitativi (npr. buuum!, pljus, hihihi) čije je značenje motivirano i bliže je neverbalnoj komunikaciji te je ovisno o kontekstu. Ovakvi se izrazi često opisuju u terminima popunjivača diskursa (engl. fillers) jer se javljaju na mjestima popunjenih pauzi i tretiraju se kao vrsta diskursnih oznaka ili kao tip neverbalne komunikacije koji ne doprinosi propozicijskom sadržaju iskaza. Sve nas to navodi na razmišljanje o odnosu šutnja/zvuk, koji možemo shvatiti kao konceptualnu komplementarnost i (potencijalno) kao okvir nužan za razvoj i postanak jezika. O tome će više biti rečeno u poglavlju 6. Ondje će se na konkretnim primjerima iz korpusa raspravljati o konceptima dijalogične šutnje i imitativa, njihove službe u funkciji diskursnih oznaka te njihove relevatnosti za shvaćanje razvojnih procesa na razini diskursa. 


\section{5. Diskurs i gramatika - funkcionalna (transfrastička) gramatika?}

Rasprava o odnosu između diskursa i gramatike jedna je od točki prijepora koje traju i danas u sklopu akademskih lingvističkih krugova. Još se uvijek postavlja pitanje kako razgraničiti područje gramatike od domene pragmatike, kako definirati njihove predmete proučavanja te što time možemo dobiti kao rezultat.

Kako i sama Badurina (2010) naglašava u podnaslovu vlastita članka Od sintakse prema suprasintaksi i dalje. Tradicionalna gramatika ili: zašto tekst nije imao sreće s gramatikom ( $i$ gramatika s tekstom), tekst pa tako ni diskurs u tradicionalnom jezikoslovlju nisu dobro prošli. U svojim uvodnim riječima autorica ističe:

„,...ako se bolje zamislimo... na (školskim) gramatikama (hrvatskoga ili kojega drugog jezika), po svojoj bi nas prilici morala čuditi posvemašnja nezainteresiranost (tradicionalne) gramatike za tekst." (2010: 43)

Ona nadalje navodi da je do toga došlo iz dvaju osnovnih razloga. Ti su razlozi sljedeći: a) zbog karaktera teksta kao složenog i slojevitog (što su strukture veće i kompleksnije, gramatika ih teže savladava i zato staje na razini rečenice), b) suvremeni gramatički opisi (i propisi) utemeljeni su na lingvističkom strukturalizmu (čak antičkoj tradiciji ${ }^{37}$ ) koji je jezičnu djelatnost podijelio na langue i parole te odredio langue (a ne parole) kao njezin predmet. Stoga ne čudi da su se takvi opisi i propisi zadržavali na razini rečenice i to rečenice kao apstraktne jezične jedinice.

Badurina tu ističe i manjkavost tradicionalne gramatike koja se (između ostaloga) manifestira u zanemarivanju konteksta komunikacije i drugih jezičnih ostvarenja koja su izvan njezina dosega. Takvi propusti tradicionalnih gramatika oslikavaju se u sljedećim pojavama: ${ }^{38}$

i. Nastanak gramatičkog viška (tzv. nekonstitutivnih dijelova rečenice). Najbolji primjer ovoga bila bi kategorija čestica koja je često rezidualna, umjesto pragmatična (poput kategorije diskursnih oznaka).

\footnotetext{
${ }^{37}$ U sklopu Aristotelovske logike nalazila se sintaksa i logika, dok je ostalo pripalo retorici, stilistici i poetici. Gramatika $=$ sintaksa kod Aristotela, i upoće u antici.

${ }^{38}$ Analiza će učiniti vidljivim da su relevantne sve četiri stavke.
} 
ii. Problem (obilježenog/neobilježenog) reda riječi, koji se najbolje objašnjava kontekstualizacijom iskaza jer je ovisan o ko(n)tekstu.

iii. Pitanje rečeničnih granica koje je teško odredivo izvan konteksta i bez parajezika. Pri tome se nameće i problem razlikovanja rečenice od iskaza.

iv. Rečenicu je potrebno sagledati u sklopu većih struktura ne bi li se bolje shvatila. Od tuda potreba za transfrastičkim gramatikama.

Ipak, funkcionalizam u gramatici svejedno postoji, no pod time podrazumijevamo različite pravce, škole i učenja koji su više iznimka nego pravilo. Badurina ovdje izdvaja tri teorijskometodološka pristupa, čemu smo sami pridodali četvrti, ali i razjasnili epistemološku relevantnost prethodnih triju pristupa. Pozabavit ćemo se stoga: 1) praškim funkcionalizmom i njihovom aktualnom sintaksom (kao jednim od pionirskih funkcionalističkih pristupa jeziku), 2) sistemskom funkcionalnom gramatikom M. A. K. Hallidaya (kao sociolingvističkim funkcionalnim i primijenjivim pristupom jeziku), 3) tekstnom lingvistikom (kao jednom od preteča diskursne analize) i 4) funkcionalnom diskursnom gramatikom (kao zaokruženim, funkcionalnim gramatičkim modelom). Ukratko ćemo proći navedenim pristupima s ciljem upućivanja na njhove prednosti pri bavljenju diskursnom razinom.

\subsubsection{Pražani i funkcionalna rečenična perspektiva}

Funkcionalizam ove teorije, pa tako i njezina korisnost za proučavanje diskursne razine, ogleda se u tome što se njome proučava iskaz u komunikacijskoj situaciji. Drugim riječima, rečenici se pristupa kao ostvarenoj, tj. aktualiziranoj a ne kao apstraktnoj jedinici jezičnog ustrojstva. ${ }^{39}$ Sama se teorija razvila u sklopu tradicije Praškog lingvističkog kruga. Sredinom pedesetih godina prošlog stoljeća Jan Fibras (1992) (na temelju ideja Viléma Mathesiusa) postavio je osnovu funkcionalne rečenične perspektive.

Okosnicu teorije sačinjava nekoliko ključnih pojmova i procesa važnih za proces komunikacije:

a) obavijesno ustrojstvo (Svaki ga iskaz ima, sastoji se od teme i reme/danog i novog.)

\footnotetext{
${ }^{39}$ Od tuda potiče i drugi naziv ove teorije: aktualna rečenična perspektiva.
} 
b) komunikacijski dinamizam (Odnosi se na organizaciju rečenice i njezinih dijelova usmjerenih na prenošenje cjelovite obavijesti. Pri tome svi rečenični elementi nemaju istu komunikacijsku vrijednost, odnosno isti stupanj komunikacijske zasićenosti, što mijenja dinamiku razmjene.)

c) kontekstualiziranost iskaza ( $\mathrm{Na}$ nju se nadovezuje i o tome ovisi dinamika komunikacije. Neki iskazi ovise o kontekstu, dok su drugi neovisni, ali omogućuju njegovu kohezivnu i koherentnu strukturu.)

d) pojam funkcionalnosti (Ovdje se izjednačava s djelovanjem, komunikacijskim djelovanjem u specifičnom kontekstu koje izaziva određene posljedice.)

Ova je perspektiva bila dobro prihvaćena u slavističkim filologijama (Badurina, 2010: 48), pa tako i u kroatističkoj (Silić i njegov pristup tekstu o kome je bilo riječi u poglavlju 2), što je usmjerilo pažnju i ostalih naših jezikoslovaca prema tekstu (primjerice Velčić i GlovackiBernardi). Također, ovaj se pristup predstavio kao svojevrsna gramatika teksta:

„... opisala je načine povezivanja rečenica u tekst (linearni i paralelni tip veze); upozorila je na elemente koji signaliziraju uključenost rečenice u kontekst (tzv. signale kontekstualne uključenosti) te ponudila njihovu iscrpunu klasifikaciju..." (Badurina 2010: 48-49)

Manjkavosti ove teorije ogledaju se u dvjema osnovnim pretpostavkama. Prva se odnosi na činjenicu da je osnovna jedinica analize i dalje ostala rečenica, jer se tekst definira i derivira iz kocepta rečenice u vidu nadrečeničnog jedinstva (tj. skupa rečenica). Pri tome se pojmu teksta pridaje premala važnost te on ostaje nerazrađen i preuzak za potencijalni razvoj suprasintaktičke teorije. Drugi se problem odnosi na činjenicu da se rečenica, kao i tekst, u sklopu ove teorije proučavaju izvan (nejezičnog) konteksta.

Može se zaključiti da ova teorija ima potencijala, no zahtijeva nadogradnju u barem nekoliko navedenih aspekata. Za proučavanje problematike diskursnih oznaka u njoj se može pronaći niša, što je evidentno i kroz ključne pojmove područja poput kocepta komunikacijskog dinamizma koji bismo primjerice mogli analizirati proučavanjem distribucije diskursnih oznaka u razgovoru (npr. istraživanje diskursne kohezije) ili pak proučavanjem njihove uloge u kontekstualizaciji iskaza. 


\subsubsection{Sistemska funkcionalna teorija i gramatika}

Ponekad nazivana i sistemskom funkcionalnom lingvistikom, tj. SFL-om, ova je teorija još jedan od primjera funkcionalnog pristupanja jeziku. Šezdesetih godina prošlog stoljeća osmislio ju je i počeo razvijati Michael Alexander Kirkwood Halliday, nastavljajući se na rad Bronislawa Malinowskog i Johna Ruperta Firtha, posebice na njihov koncept konteksta situacije. Danas se ova teorija naširoko upotrebljava, posebice u sklopu primijenjene lingvistike, tj. jezičnog obrazovanja i jezičnog usvajanja, te u sklopu analize diskursa. Često se usko vezuje uz područje sociologije zbog svoje usredotočenosti na društvene aspekte jezika i na empirijske podatke. Mentalizam je ovdje stavljen na stranu da bi u prvi plan došlo proučavanje jezičnih funkcija i teksta kao osnovne jedinice jezičnog ostvaraja.

Za razliku od prethodnog pristupa, SFL tekstu pridaje mnogo veću važnost, postulirajući da je jezik mnogo više od pukog niza ili zbroja rečenica. Nadalje, Halliday i Hasan (1976: 2) to razrađuju i tvrde da je povezanost između različitih dijelova teksta drugačijeg tipa od one koja se uspostavlja među dijelovima ostvarene rečenice, tj. iskaza, te pružaju teorijsko-metodološki okvir kako to istražiti.

U sklopu SFL-a tekst se analizira na četiri načina, tj. na četiri osnovne razine (Almurashi 2016: 72): razini konteksta, razini semantike, leksičko-gramatičkoj i fonološkoj razini. S obzirom na problematiku ovog rada, razine relevantne za ovu diskusiju razine su konteksta i semantike. Razine leksika i sintakse te fonološka razina ovdje će samo ukratko biti obrađene. Više će se pažnje posvetiti prethodnim dvjema razinama jer pružaju potencijalni okvir za pristup diskursnim oznakama. Kontekst unutar kojeg se jezik ostvaruje Halliday dijeli na: kontekst kulture (žanrove) i kontekst situacije (registre). Nadalje, kontekst situacije povezuje se s jezičnom upotrebom u kojoj govornik formira tekst, što se odvija u trima pravcima: polje (koje nam pruža temu razgovora), sadržaj (interpersonalni odnos uključen u jezične aktivnosti) i način (odnosi se na jezični kanal).

U sklopu isključivo jezičnog dijela ovog modela prva se razina analize naziva diskursnosemantičkom i bavi se trima jezičnim metafunkcijama: interpersonalnom, ideacijskom i tekstualnom. Posredstvom navedenih funkcija ocrtavaju se i tri osnovne vrste značenja koje se prenose jezikom: interpersonalno, iskustveno i tekstualno, što se kasnije odražava na drugim jezičnim razinama. Stoga se primjerice u morfosintaksi bilježi prijelaznost glagola koju smo 
osjetili u našem iskustvu. Raspoloženje i modalnost određuju interpersonalna značenja, a ona tekstualna obuhvaćaju obavijesno ustrojstvo poruke temu i remu, tj. tematsko rematske odnose.

Naposljetku možemo zaključiti da je SFL iznimno primijenjiva lingvistička teorija i pokazala se takvom u upotrebi u raznovrsnim poljima ljudskog djelovanja: od zdravstva, računalne lingvistike, prevođenja, multimodalnih studija i obrazovanja. Povrh svega, SFL se pokazala korisnom kod proučavanja žanrova, diskursne kohezivnosti i registara, i proširila se izvan okvira jezikoslovlja, u ostale društvene i humanističke znanosti.

\subsubsection{Tekstna lingvistika i njezini doprinosi funkcionalnom pogledu na jezik}

Govoreći o studijama o diskursu, tekstu i diskursnim oznakama na našim prostorima, već smo se dotakli područja tekstne lingvistike, tj. lingvistike teksta. ${ }^{40} \mathrm{Njezina} \mathrm{se} \mathrm{relevatnost} \mathrm{ogleda}$ u nekoliko činjenica: u njezinom povijesnom značaju za proučavanje nadrečenične razine jezika, u njezinoj percepciji i definiciji teksta i u njezinom iznimno primijenjivom karakteru koji pogoduje analizi jezičnih ostvaraja.

Povijesni značaj tekstne lingvistike proizlazi iz činjenice da je ona kao teorija i metoda jedna od preteča analize diskursa, no mnogo je statičnija i više je usredotočena na tekst, a manje na sudionike komunikacije. Tu na vidjelo izlaze i njezine osnovne mane. Drugim riječima, ovdje se u obzir uzima kotekst, tj. jezični kontekst, ali ne i izvanjezični kontekst, tj. socijalni, kulturni i ostali aspekti komunikacije. Za razliku od tekstnih lingvista, sociolingvisti poput Hallidaya, analitičari diskursa (posebice u sklopu kritičke lingvistike) i lingvistički antropolozi u svoje pristupe uključuju cjelokupni kontekst situacije.

Ono u čemu se lingvistika teksta istaknula zasigurno je njezino shvaćanje teksta i pristupanje samom tekstu kao osnovnoj i početnoj jedinici jezične analize. Beaugrande i Dressler (2010) u svome priručniku Uvod u lingvistiku teksta pomno razrađuju pojam teksta. Oni su pomaknuli fokus znanstvenih istraživanja s rečenice, tj. s rečeničnog iskaza i međurečeničnih veza, na sam tekst i njegova osnovna obilježja, tj. na njegovu tekstualnost. Prema ovim autorima moguće je prepoznati sedam kriterija tekstualnosti, odnosno sedam osnovnih obilježja teksta u koje spada: kohezivnost, koherentnost, intencionalnost, prihvatljivost, informativnost, situativnost i intertekstualnost. Spomenuti kriteriji čine okosnicu ovog pistupa i s pomoću njih se konkretno

\footnotetext{
${ }^{40}$ Vidi poglavlje 2.1., podnaslov „Tekstna lingvistika - Velčić i Glovacki-Bernardi“
} 
može analizirati određeni jezični korpus. Neki od njih, u prvom redu kriterij koherentnosti (značenjsko jedinstvo teksta, smislenost i retorička struktura), zatim kohezivnosti (gramatička povezanost teksta) i informativnosti, pokazat će se od velike koristi pri određivanju kategorije diskursnih oznaka i njihovih obilježja, kao što ćemo vidjeti u poglavlju 4. koje slijedi. Ipak, prije no što krenemo dalje, zaokružit ćemo raspravu o značaju i potencijalu koji se krije u funkcionalnim pristupima jeziku, govoreći o funkcionalnoj diskursnoj gramatici kao još jednom od mogućih modela transfrastičke gramatike.

\subsubsection{Funkcionalna diskursna gramatika - na razmeđi između forme i funkcije}

Za razliku od prethodno opisanih pristupa, funkcionalna dikursna gramatika (FDG) teorija je nešto novijeg datuma. Osmislili su je autori Hengeveld i MacKenzie u prvoj dekadi 21. stoljeća $i$, kao što sami ističu, ona predstavlja tipološki zasnovan model ${ }^{41}$ jezične strukture (Hengeveld i MacKenzie 2008: 1). To je teorija koja kreće odozgo prema dolje, tj. od pragmatike prema fonologiji, odnosno od komunikacijske namjere prema artikulaciji i sama sebe određuje kao zlatnu sredinu između ekstremnog formalizma, ali i ekstremnog funkcionalizma u jezikoslovlju.

FDG je zamišljena kao gramatička sastavnica (engl. grammatical component) šireg modela verbalne interakcije, u sklopu kojeg se povezuje s konceptualnom, izlaznom i kontekstualnom (nejezičnom) sastavnicom dvama osnovnim procesima: procesom formulacije i procesom kodiranja (grafički prikaz 6 na sljedećoj stranici).

Proces formulacije odnosi se na dvije vrsta pravila: pravila uspješne pragmatičke interpretacije i na pravila validne semantičke reprezentacije. S druge strane, proces kodiranja obuhvaća pravila prebacivanja pragmatičkih i semantičkih informacija u one morfosintaktičkog i fonološkog tipa. Prema mišljenju autora oba su navedena procesa jezično specifična, tj. razlikuju se od jezika do jezika zbog zasebnih tipoloških karakteristika svakog jezika. Zanimljivo je da upravo to obilježje teorije otvara pristup bavljenju jezičnim univerzalijama.

\footnotetext{
${ }^{41}$ Autori vlastiti model nazivaju tipološkim jer se zasniva na postavkama lingvističke tipologije, čiji je osnovni cilj opisati i objasniti jezične univerzalije i jezičnu raznolikost. Pri tome se oslanjaju kako na formalna tako i na funkcionalna obilježja jezika te se obraća pozornost na sve jezične razine.
} 
Konceptualna sastavnica modela smatra se osnovnom pokretačkom snagom jezika, tj. pokretačem gramatičke sastavnice, jer je upravo ona odgovorna za formiranje komunikacijske namjere (intencije).

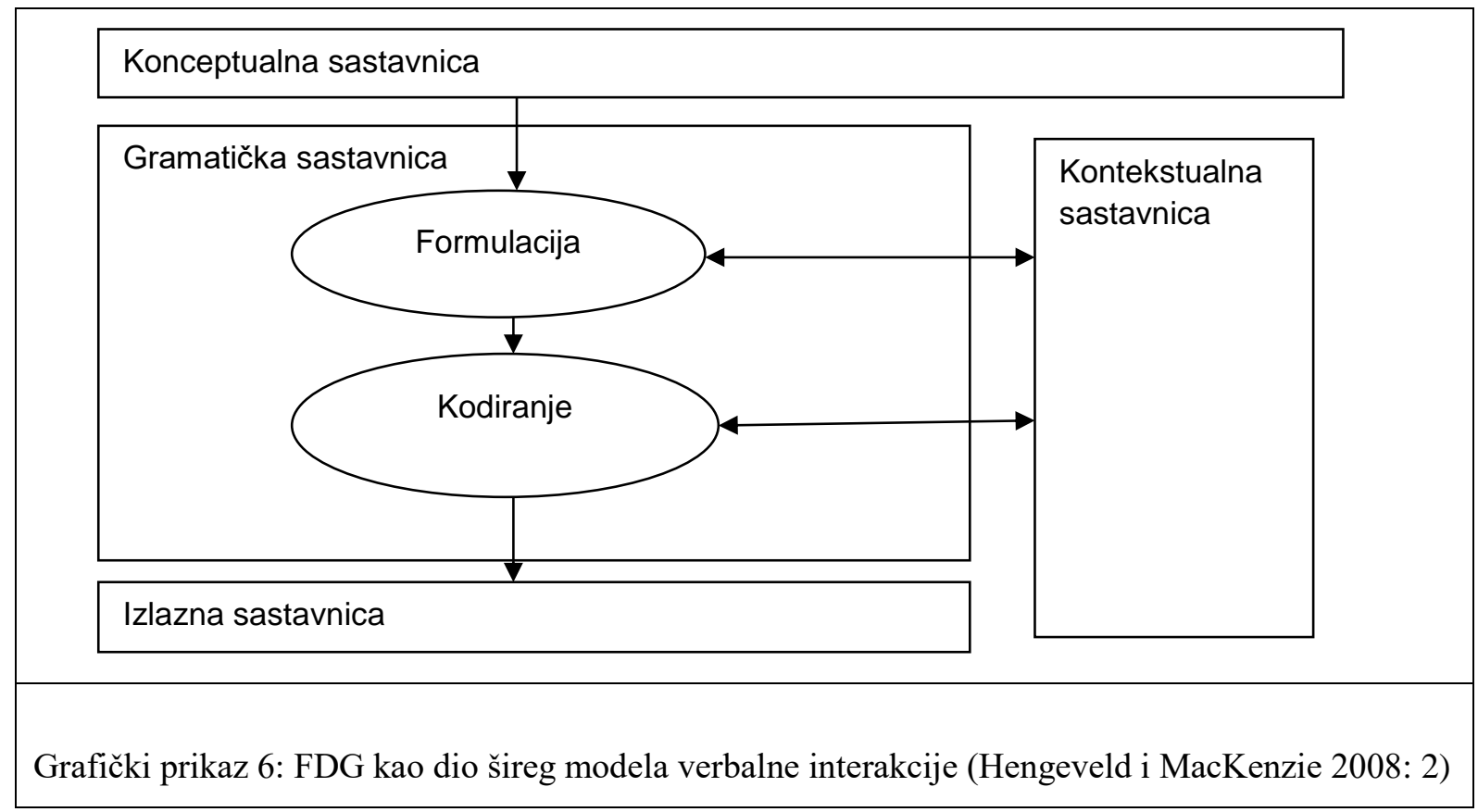

Kontekstualna sastavnica predstavlja informacije o prethodnim diskursima, o trenutnom kontekstu komunikacijskog čina te o društvenim odnosima među sudionicima interakcije. Te su informacije relevantne, a najbolje dolaze do izražaja pri formiranju narativa.

Izlazna sastavnica stvara akustičke ili pisane izraze na temelju informacija koje pruža gramatička sastavnica. Vrlo je upečatljiva analogija kojom se autori ovdje koriste ne bi li dočarali osnovnu funkciju ove sastavnice kao elementa koji digitalni kod pretvara u analogni:

"Its function may be seen as translating the digital (i.e. categorical, opposition based) information in the grammar into analogue (i.e. continuously variable) form." (Hengeveld i MacKenzie 2008: 3)

Osnovni je cilj ove teorije pružiti cjeloviti morfosintaktički i fonološki opis nekog jezika na dva moguća načina: funkcionalnim objašnjenjem procesom formulacije ili formalnim tumačenjem procesom kodiranja. FDG naglasak stavlja na funkcionalni pristup argumentirajući preferiranje tog izbora na sljedeći način: 
„The functionalist stance entails the hypothesis that a wide range of formal categories can be insightfully explained if they are brought into correspondence with semantic and pragmatic categories rooted in human cognition and interhuman communication; only if no such correlation can be found will FDG contenance the option of arbitrariness." (Hengeveld i MacKenzie 2008: 6)

Nadalje, gramatička sastavnica, tj. strogo jezična komponenta ovog modela, sastoji se od hijerahijski ustrojenih razina i slojeva (engl. levels and layers), što je vidljivo iz grafičkog prikaza 7 na sljedećoj stranici.

Interpersonalna je razina ona na kojoj djeluju retorički principi i koordiniranje socijalnih odnosa, kako na makro tako i na mikro razini. U prvom slučaju oni osiguravaju strukturu i uspješno funkcioniranje cjelokupnog diskursa, dok se u drugome tiču specifičnog konteksta situacije i samih aktera. Sve se navedeno nužno manifestira u jeziku i gramatički je relevantno. Stoga, kao primjer djelovanja retoričkih principa možemo navesti Griceov princip kooperativnosti ili strukturu minimalnog narativa, dok za koordinaciju socijalnih odnosa primjeri mogu biti upotrebe specifičnih žanrova, sociolekata ili osobnih idioma.

Slojevi ove razine sastoje se od: poteza, diskursnog čina, ilokucije, govornika, primatelja, komuniciranog sadržaja i podčinova. Potez (engl. move) je najveća jezično relevatna jedinica ove razine. Definira se kao autonomni doprinos tekućoj interakciji: on ili zahtijeva reakciju ili je sam reakcija (Hengeveld i MacKenzie 2008: 9). Potez će uvijek poprimiti oblik jednog ili više diskursnih činova, koji pak mogu varirati od tišine pa sve do podužih dijelova diskursa. Diskursni čin autori dijele na tri moguće vrste: ekspresive (npr. Jao!), interaktive (npr. Čestitam!) i kontentive (npr. Obećajem da ću doći sutra./Doći ću sutra.). Ovdje je nemoguće ne primijetiti veliku podudarnost FDG-a s teorijom govornih činova koju smo spominjali u podnaslovu 3.2. (Pragmatika i analiza diskursa cyber-prostora). Brojne sličnosti s tom već klasičnom pragmatičkom teorijom ne staju ovdje. Autori napominju da se diskursni činovi mogu modificirati leksemima u funkciji diskursnih oznaka. Iako ih sami ekspicitno tako ne imenuju, iz primjera Honestly, I don't like you. (2008: 10) jasno se vidi da se radi o upotrebi DO-a s ciljem mijenjanja ilokucijske snage iskaza. 


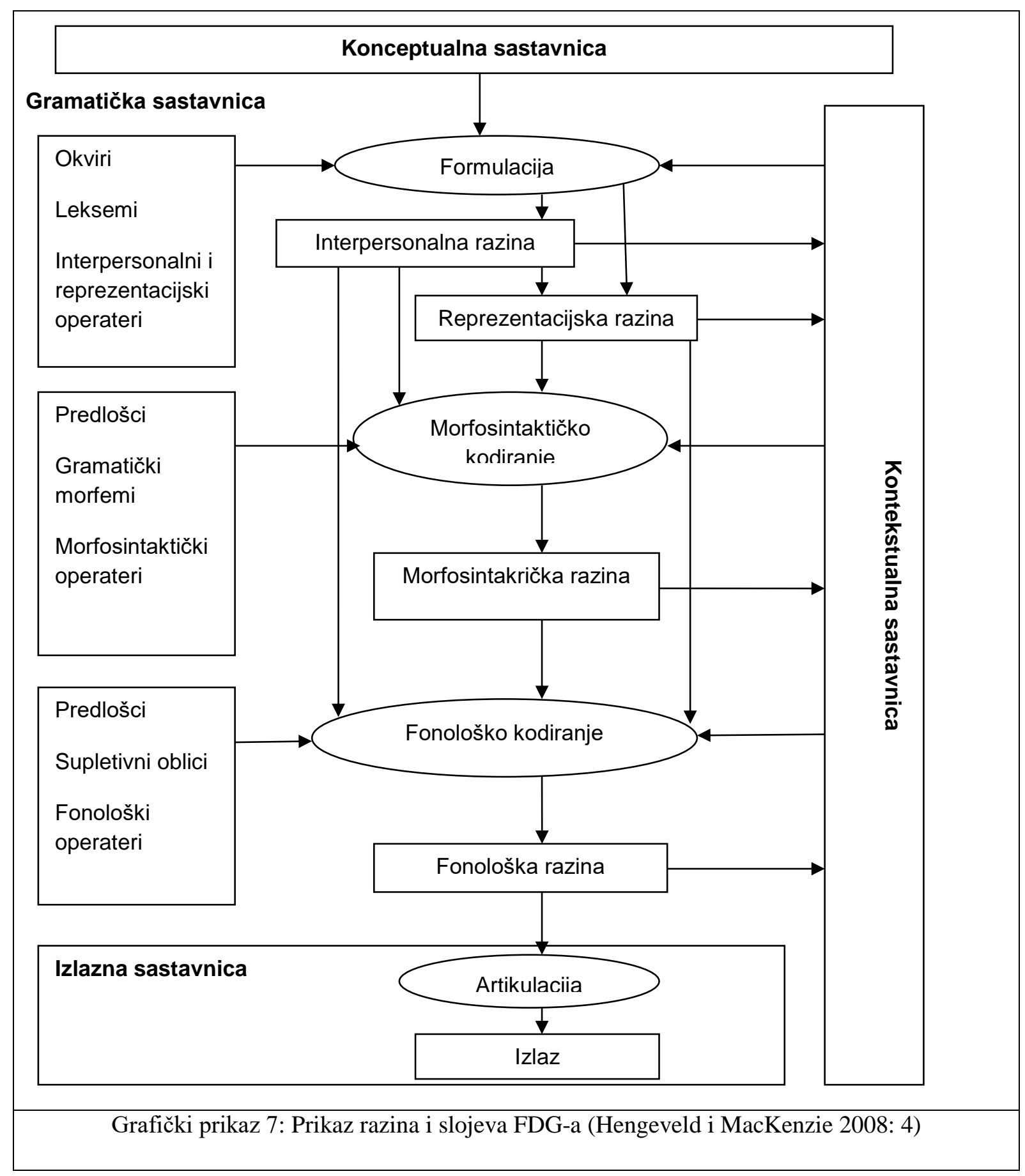

Nadalje, svaki se diskursni čin sastoji od podčinova koji prenose pragmatičke funkcije. Autori navode tri vrste spomenutih funkcija:

1. funkciju fokusa (određuje govornikov strateški odabir novih informacija, s ciljem popunjivanja praznina u informiranosti sugovornika ili s ciljem ispravljanja već postojećih informacija), 
2. funkcija teme (povezuje komunicirani sadržaj s kontekstom),

3. funkcija kontrasta (signalizira govornikovu želju da istakne razlike između sadržajā i/ili sadržaja i konteksta).

Ovdje se ističe da su funkcije teme i fokusa obično kodirane u jezicima, dok je formalni „Zapis“ dodatnih informacija (poput komentara) mnogo rjeđi. Ipak, moramo pridodati da u slučaju komunikacije na mreži to nije tako. Štoviše, zbog nepostojanja zajedničkog fizičkog konteksta komunikcije, vrlo je često bilježenje komentara ili dodatnih opisa pozadine (gotovo poput didaskalija), često u obliku parenteza.

Uz osnovne pragmatičke funkcije koje se prenose podčinovima sami se podčinovi mogu javiti u dvama osnovnim oblicima: kao askriptivni (pripisujući) jer prizivaju obilježja ili kao referencijalni jer prizivaju referenta.

Reprezentacijska razina bavi se semantičkim aspektom jezične (gramatičke) sastavnice. Za razliku od interakcijske razine koja se bavi prizivanjem (engl. evoking) obilježja, ova se razina bavi označivanjem. Slojevi su ove razine sljedeći: propozicijski sadržaj, epizoda, stanje stvari (engl. state-of-affairs), svojstva konfiguracije, leksička svojstva i pojedinac.

U propozicijski sadržaj ubrajaju se mentalni konstrukti poput dijelova znanja, vjerovanja i nadanja, koji mogu, ali i ne moraju biti utemeljeni na činjenicama. Ostvaruju se u vidu propozicijskih stavova (iskazivanje sigurnosti, sumnje, nevjerice) i u vidu njihova porijekla (enciklopedijsko znanje, osjetilno iskustvo, zaključivanje). Propozicijski sadržaji sastoje se od epizoda, koje se pak sastoje od stanja stvari čije je osnovno obilježje tematska koherentnost. Nadalje, stanja stvari tvore događaji i stanja pojedinaca (aktera), a svojstva konfiguracije zapravo su semantičke kategorije u nehijerarhijskom odnosu, poput lokacije, vremena, načina, količine i td.

Morfosintaktička razina bavi se strukturom jezičnih jedinica i kodiranjem interpersonalnih i reprezentacijskih razlika. Autori ističu da je i ona funkcionalno motivirana, no da jednako tako ima i vlastita pravila organizacije, poput proizvoljnog (arbitrarnog) nametanja obrazaca poretka osnovnih sastavnica. Kao što je vidljivo iz samog naziva ove razine, FDG ne razdavaja morfologiju od sintakse, argumentirajući to tvrdnjom da su principi tvorbe riječi jednaki onima tvorbe fraza i rečenica. Ipak, moramo uzeti u obzir činjenicu da su autori vođeni engleskim jezikom koji sam po sebi ima osiromašenu morfologiju pa to kompenzira na razini sintakse. Slojevi ove razine kreću od jezičnog izraza, prema glavnoj ili zavisnoj rečenici (engl. clause), 
frazi te riječi, da bi završila na korijenu i afiksu. Time bi jezični izraz (engl. linguistic expression) bio najveća morfosintaktička kategorija, što bi omogućilo bavljenje holofrazama i nadrečeničnim iskazima.

Fonološka razina dobiva ulazne informacije od svih triju prethodno navedenih razina $\mathrm{i}$ osigurava sadržaj izlazne sastavnice. Sastoji se od sljedećih slojeva: iskaza, intonacijske fraze, fonološke riječi, stope i sloga.

Sve se sastavnice nalaze u neprestanoj međuigri, što najbolje prikazuju primjeri koje navode i sami autori (Hengeveld i MacKenzie, 2008: 27). Jedan od njih bio bi iskaz u grafičkom prikazu 8:

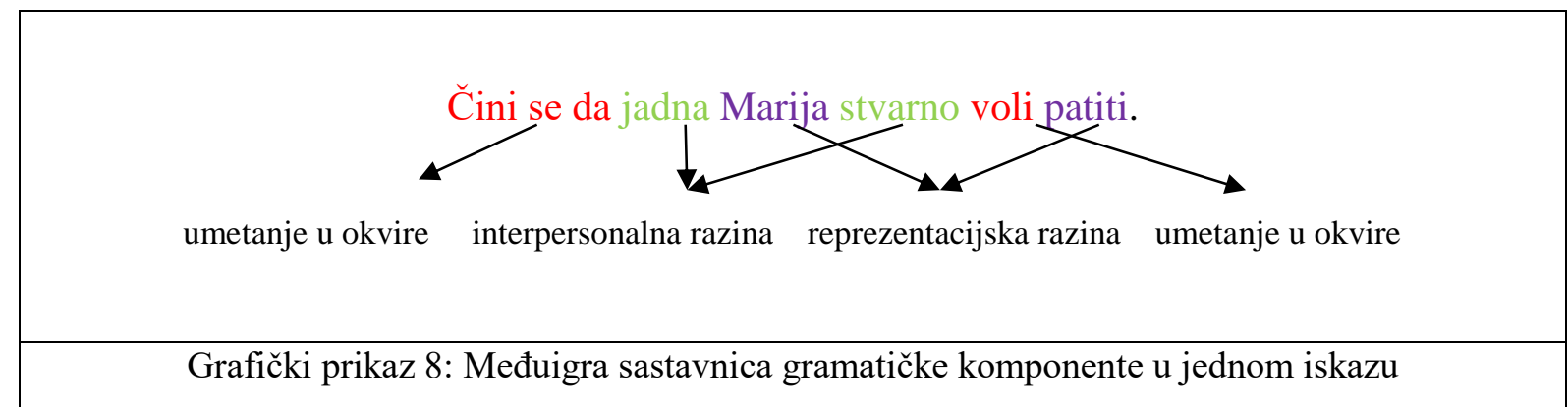

Uz ovakve klasične primjere, u okviru ovog modela mogu se proučavati i atipične jezične pojave poput fonetskog simbolizma (onomatopeje, ideofoni, imitativi i sl.). FDG tu pojavu, kao i njezine produkte, objašnjava kao neposrednu povezanost reprezentacijske i fonološke razine (preskakanjem međurazina). Iako hrvatski jezik ne poznaje ideofone, u cyber-komunikaciji često je korištenje onomatopeja, tj. imitativa sa svrhom kontekstualizacije iskaza. Također, moguća je i neposredna povezanost interpersonalne s fonološkom razinom koja se ogleda primjerice porastom frekvencije glasa zbog nelagode ili laganja.

Osim za analizu sinkronijskih podataka, autori ove teorije tvrde da se njome nastoji pružiti okvir i za analizu dinamičnih podataka: jezičnog usvajanja, jezičnog postanka i jezične promjene. FDG stoga nudi dvije razine kao polazišta za proučavanje dijakronijskih procesa:

1. Prvom se kreće od promjena koje se zbivaju među razinama, a bilježe se u jeziku, tj. gramatički su relevantne. Tu bi primjerice spadala istraživanja vezana uz procese gramatikalizacije i subjektifikacije. 
2. Drugo polazište u središte stavlja odnos slojeva neke razine i njihov razvoj. Tu stoga spadaju istraživanja o jezičnom usvajanju, koja nam pak daju uvid u sveukupnu jezičnu evoluciju i postanak.

Na samome kraju ovog podnaslova o FDG-u, kao i čitavog odlomka vezanog za funkcionalne pristupe jeziku, možemo ustvrditi da oni ni u kojem slučaju ne predstavljaju prijetnju tradicionalnijim pristupima, pa tako ni onim strogo formalnim. Također, pokazuju se iznimno korisnima za pručavanje brojnih jezičnih fenomena koji su se često smatrali rubnojezičnima, iako to nisu. Problem je bio u metodama kojima im se pristupalo. Iako smo ovdje predstavili više različitih funkcionalnih pristupa, ne zauzimamo se ni za jedan izolirano. Oni su ovdje navedeni i predstavljeni kao primjeri sa svim svojim prednostima i manama, s ciljem ukazivanja na njihov često previđeni potencijal. Zbog epistemološke vrijednosti namjerno smo obrađene pristupe poredali prema kronologiji njihova nastanka, no nastojali smo pokriti i što veći spektar mogućnosti koje lingvistički funkcionalizam pruža analitičaru. Iz tog smo razloga započeli s pražanima gdje je ideja o transfrastičkom pristupu jeziku bila još u povojima, zatim smo prešli na Hallidaya koji je s pomoću socijalnih aspekta komunikacije odredio tekst kao osnovu i polazište svoje analize i gramatike. Nakon SFL-a ukratko smo se pozabavili tekstnom lingvistikom, ponajviše zbog određenih kriterija tekstualnosti koji će nam biti od velike koristi za našu analizu. Naposljetku, nastojali smo zaokružiti čitavu raspravu modelom i teorijom FDG-a koji predstavlja integraciju pragmatičkih (teorija govornih činova) i sociolingvističkih teorija (interakcijska sociolingvistika) sa strukturalno-formalnim pristupima jeziku, tj. s čomskijanskim shvaćanjem sintakse i tradicionalno-gramatičkim pristupom fonologiji (jezična arbitrarnost, binarizam i sl.). Na posljetku, sve je potaknuto namjerom koja se formira $u$ konceptualnoj komponenti.

U posljednje se vrijeme ponovno javlja osvježeni interes za funkcionalizam u jezikoslovlju, posebice za potrebe proučavanja nadrečenične razine i jezičnih korpusa kao vidova realne jezične upotrebe. Vjerujemo da se uzrok tome nalazi čak i izvan same struke, u sociopolitičkim promjenama, globalizaciji i tehnološkom napretku. To se ogleda u prebacivanju s ideologije preskriptivizma (koju odlikuje nametanje arbitrarnih normi jezične upotrebe, potaknuto sociopolitičkim motivima), na deskriptivizam (kojim se potencira objektivnost i usmjeruje se na isključivo jezični opis, bez nametanja propisa), te na čisti pragmatizam (koji u jeziku vidi oruđe za planiranje, rješavanje problema i djelovanje). Uz svoju primijenjivost pragmatizam sa sobom nosi i potencijal kritike, ali i sve veću potrebu za interdisciplinarnošću, multidisciplinarnošću i transdisciplinarnošću. 
Iako je čitavo ovo poglavlje napisano u znaku skiciranja nove domene pragmatičkih istraživanja: opisu i objašnjenju područja cyber-pragmatike i prirodi cyber-diskursa, njime se nastojalo približiti i nekim dugovječnijim problemima unutar lingvistike. Poglavlje je iz tog razloga otvoreno općenitim obilježjima i opisom nove pragmatičke subdiscipline te njezinim razgraničenjem od drugih srodnih disciplina. Potom su prikazani neki od klasičnih i neophodnih teorijsko-metodoloških pristupa koji su neosporivo utjecali na domenu cyber-pragmatike (klasična pragmatika, konverzacijska analiza i istraživanja neverbalne komunikacije). Naposljetku, sva su promišljanja o formiranju nove discipline dovela do jasnog artikuliranja potrebe za transfrastičkim gramatikama i formiranjem funkcionalnih pristupa za analizu jezika, pri čemu se FDG za sada pokazao najadekvatnijim modelom.

U nastavku rada prebacit ćemo se na temu diskursnih oznaka u kontekstu cyberkomunikacije. Uz primarni cilj razjašnjenja kategorije diskursnih oznaka (kako u sinkroniji tako i u dijakroniji), vlastitim eklektičnim pristupom (cyber-pragmatičkim pristupom) nastojat ćemo demonstrirati korisnosti svih prethodno navedenih teorija i metoda, kao i novijih spoznaja vezanih za jezik, diskurs i nove medije. 


\section{KATEGORIJA DISKURSNIH OZNAKA - primjeri s mreže}

U ovome dijelu rada pozabavit ćemo se osnovnim problemima kategorije diskursnih oznaka u sinkronijskom presijeku. Prije svega osvrnut ćemo se na proces i značaj imenovanja same kategorije u pitanju i obrazložiti vlastiti terminološki odabir.

Nakon problema s nazivljem, fokus će se prebaciti na vrlo blisku tematiku: problem definiranja kategorije. Ovdje će do izražaja doći i epistemološki problemi, tj. relevantnost upoznatosti s različitim lingvističkim teorijama i metodama koje su se iz vlastite perspektive bavile istim problemom: temom DO-a.

No, da bismo uspješno definirali i razgraničili diskursne oznake od ostalih jezičnih i pragmatičkih kategorija, potrebno je otkriti i opisati najrelevantnije kriterije za određenje kategorije.

Sve navedeno bit će upotpunjeno primjerima iz dvaju korpusa razgovorā na mreži (instant poruke/chat), od kojih je prvi korpus ciljni i privatan te obuhvaća 600 razgovora vođenih razmjenom instant poruka (upotrebom aplikacija hangouts, facebook messenger, whatsapp), dok je drugi korpus referentni korpus od 600 razgovora izabranih s Hrvatskog mrežnog korpusa $(h r W a C)$.

\section{1. Terminologija i problemi definiranja diskursnih oznaka}

Terminološka šarolikost koja je iznimno prisutna kada govorimo o problematici diskursnih oznaka u znanstvenim se krugovima obično karakterizira kao velik problem i prepreka pri njihovu proučavanju. Ipak, ako smo toga svjesni, taj dugotrajni i kompleksni proces imenovanja i definiranja kategorije DO-a može nam mnogo toga reći o njima samima, ali i o struci. Na preferiranje određenog nazivlja možemo gledati kao na naznaku užeg područja interesa istraživača, tj. njegova polazišta i cilja njegova istraživanja (npr. je li se kategoriji pristupalo iz tekstnolingvističke, semantičke ili sociopragmatičke perspektive). Također, imenovanje kao i definiranje kategorije DO-a upućuje nas i na epistemološku povijest struke (npr. na pomak fokusa od rečenice prema tekstu, zatim od teksta prema diskursu itd.), no jednako tako otkrivaju 
se i trendovi kojima se jezikoslovna zajednica priklanjala (npr. favorizioranje formalizma na uštrb funkcionalizma).

Prolazivši raznovrsnom literaturom ove problematike, susrest ćemo se s brojnim pojmovima koji se odnose na kategoriju diskursnih oznaka. Neki će se od njih u potpunosti preklapati u značenju i smislu, neki će biti u hiperonimnom, neki u hiponimnom odnosu, a ponekad će se pojaviti i homonimi. No da bi se najbolje dočarala terminološka plodnost, najbolje je navesti ponešto primjera iznimno inspirativnih i kreativnih naziva za DO-e ${ }^{42}$ : konverzacijske oznake (conversational markers), oznake tekstnih odnosa (text-relation markers), kontekstualne oznake (context markers), razne vrste čestica (modal, utterance, final sentence particles), različite vrste konektora (rečenični, diskursni, fatički), metajezični operatori, kohezivna sredstva, parenteze, popunjivači (fillers), oklijevači (hesitators), ograde (hedges) i brojni drugi.

Bez obzira na veliko bogatstvo nazivlja u svjetskoj literaturi, s vremenom su se iskristalizirala i zadržala tri sveobuhvatnija, općenitija termina. To je svakako termin diskursne oznake, zatim naziv diskursne čestice i termin konektori. Za potrebe ovog rada odabran je termin diskursne oznake iz nekoliko razloga: dovoljno je širok i samim time pokriva kompleksnost i raznovrsnost čitave kategorije (kao krovni pojam), s druge strane takvo nazivlje dozvoljava uvođenje jasnih potkategorija i detaljnije razrađivanje problematike. Također, termin diskursna oznaka naznačava relevantnost diskursne razine i pragmatičnu prirodu kategorije, te za razliku od drugih dvaju pojmova (diskursne čestice i konektori) ne unosi višeznačje i nejasnoće u percepciju i shvaćanje kategorije. Naposljetku, sam je termin niknuo i iznimno se popularizirao unutar anglosaksonske tradicije koja je bila pod utjecajem analize diskursa i pragmatike, što sačinjava i naše teorijsko-metodološko polazište.

Diskursne čestice, tj. partikule termin je koji je zauzimao drugo mjesto po frekvenciji uporabe sve do sredine 80-ih godina 20. stoljeća (Schourup 1999: 229), no sam se termin pokazao iznimno problematičnim iz nekoliko razloga. Naziv čestica tradicionalno je sintaktički termin, neprecizan je jer se klasa čestica i unutar sintakse definira negativno, često kao klasa preostalih riječi koje nisu svrstane u neku od drugih sintaktičkih kategorija. Također neadekvatno je nazivati klasu ovakvih izraza partikulama, kad u nju možemo ubrojiti čitave fraze, tj. višečlane izraze. Stoga, bez obzira na činjenicu da čestice obično obnašaju isključivo gramatičku funkciju, tj. predstavljaju funktive, kratke su i nepromjenjive riječi, ogoljene od svojeg izvorišnog semantičkog sadržaja, pojmovna pokrivenost kategorije koju nam pruža taj

\footnotetext{
${ }^{42}$ Za detalje vidi Dolić (2016: 24-25).
} 
termin nije dostatna ni adekvatna. Danas se većina jezikoslovaca složila da naziv čestica, tj. partikula nije najbolji izbor jer previše podsjeća na čestice kao (morfo)sintaktičku kategoriju (Zwicky 1985 i Schourup 1999). Ipak, u sklopu njemačke jezikoslovne tradicije upotreba termina diskursna čestica i dalje se zadržala i odande se proširila u francusku, dansku i kinesku lingvistiku (Dolić 2016: 26).

Treći, također relativno popularan naziv kategorije dolazi nam iz talijanske jezikoslovne tradicije koja je bila pod velikim utjecajem tekstne lingvistike. Riječ je o terminu (diskursni) konektori. Već je na prvu jasna i njegova problematičnost zbog sličnosti s veznicima kao vrstom riječi, nedovoljnom preciznošću i ponešto preuskim shvaćanjem kategorije. S vremenom je ovaj termin ,istisnut” iz literature u korist drugih dvaju naziva: diskursne čestice i/ili diskursne oznake, no može poslužiti za imenovanje potkategorije diskursnih oznaka.

Zaključno, o nazivlju kategorije možemo ustvrditi da termin oznaka dobro upućuje na sadržaj i funkciju ove klase izraza koja je primarno vezana uz pragmatiku i diskursnu razinu. Oznake nam stoga naznačuju, prenose i modificiraju kategoriju intencionalnosti govornikā, koordiniraju čitav tijek komunikacijskog procesa i integriraju komunikacijski čin u smislenu cjelinu.

No, što se događalo s definicijom kategorije diskursnih oznaka i kako je odrediti? Nakon velikog terminološkog kaosa nije teško pretpostaviti da će ponuda definicija ove kategorije biti još zamršenija i opsežnija. Ipak, da bismo pružili barem okvirnu sliku o stanju definiranja ove klase izraza, navest ćemo nekoliko releventnijih autora koji su se posvetili ovoj problematici i pružili vlastite definicije. Naposljetku, nastojat ćemo pružiti vlastito viđenje i shvaćanje diskursnih oznaka.

Ako krenemo kronološkim slijedom, prvo ćemo se susresti s tumačenjem Hallidaya i Hassana (1976) koji diskursne oznake predstavljaju kao sredstva za ostvarenje kohezivnosti i koherentnosti teksta. Schiffrin (1987) nas upućuje na činjenicu da su DO-e elementi koji omeđuju jedinice govora i pružaju nam kontekstualne koordinate za tekući razgovor. Lenk ih (1998) definira kao manje leksičke jedinice, povezane s pragmatičkim značenjem na metajezičnoj razini diskursa, čija je svrha trenutni govornikov iskaz povezati s prethodnim ili diskursom koji slijedi. Fraser (1999) tvrdi da one predstavljaju kategoriju diskursnih konektora jer je pretežno riječ o pomagalima koja povezuju različite dijelove diskursa. Badurina (2008: 36-37) ih definira kao ukazivače diskursne strukture, jer se s pomoću njih uspostavljaju odnosi među različitim elementima diskursa, kao i veze sa širim kontekstom situacije. Ovdje je također 
prilika da se istakne podatak da su diskursne oznake pronašle svoj prostor i u gramatikama engleskog jezika na internetu, u mrežnim izdanjima (jedan od primjera bio bi Cambridgeov riječnik i gramatika engleskog jezika ${ }^{43}$ ). Ondje se DO-e definiraju kao izrazi ili fraze s pomoću kojih se povezuje, organizira i kontrolira jezična razmjena ili izražava osobni stav govornika.

Nakon svega izloženog, kategoriju diskursnih oznaka odredili bismo na sljedeći način. Definirali bismo je kao kategoriju jezičnih izraza koja djeluje na pragmatičkoj (uporabnokomunikacijskoj razini), tj. diskursne oznake bile bi shvaćene kao vrsta jezičnih izraza koji nam pružaju kontekstualne koordinate određenog iskaza i koji pospješuju njegovu koherentnost i što točniju interpretaciju govornikova značenja. Takvim shvaćanjem, DO-e će biti uključene u jezični sustav kao punopravna (pragmatička) kategorija. Pri tome će njihova funkcija biti stavljena u prvi plan i odredit će njihovu daljnju podjelu, tj. kategorizaciju.

\section{2. Utvrđivanje formalnih kriterija za pripadnost kategoriji diskursnih oznaka}

Ostavivši razlike po strani, postoji nekoliko osnovnih odlika diskursnih oznaka koje se spominju u različitim teorijama i mogu se smatrati njihovim osnovnim i obaveznim atributima.

Prvo takvo obilježje bila bi vezivnost. Ova se karakteristika može primijetiti kod različitih autora, u njihovim određenjima kategorije u pitanju. Tako primjerice Fraser navodi da su diskursne oznake izrazi koji signaliziraju odnos glavne poruke s prethodnim diskursom (1996: 186). S druge strane Schiffrin (1987: 31) ističe da su one deiktične po svojoj prirodi:

„Sequentially dependent elements which bracket units of talk... where the beginning of one unit is the end of another."

Međutim, vezivnost nije zamišljena samo na prethodno spomenute načine. Prema Blakemore (1992: 87) ova se kvaliteta može shvatiti još šire. Ako DO-e shvatimo kao izraze koji povezuju dijelove nekog propozicijskog sadržaja, njihovo se obilježje vezivnosti širi i na područje neverbalnog i parajezičnog. Drugim riječima, povezani sadržaj ne mora nužno doći u obliku teksta. Naposljetku, ovo se obilježje najbolje reflektira u kohezivnosti određenog diskursa, čijem ostvarenju doprinose diskursne oznake kao kategorija vezivnih izraza.

\footnotetext{
${ }^{43}$ Dostupno na URL: https://dictionary.cambridge.org/grammar/british-grammar/discourse-markers-so-rightokay (3.ožujka 2020.)
} 
Fakultativnost je još jedna od često spominjanih odlika kategorije diskursnih oznaka. Velika većina autora smatra da su diskursne oznake sintaktički opcionalne jer se njihovim brisanjem neće narušiti gramatikalnost rečenice. Također, iz semantičke se perspektive diskursne oznake mogu shvatiti kao potpuno neobavezne jer ne povećavaju mogućnosti semantičkih veza među elementima koje povezuju. Drugim riječima, ako ih izostavimo, veza koju one signaliziraju i dalje će biti dostupna, ali ne i eksplicitna. Dakle, fakultativnost tj. izbornost kao kriterij odnosi se na razinu sintakse i semantike, u čijim su se sferama zato diskursne oznake rubno obrađivale i s teškoćom objašnjavale. Posljedično tome došlo je do otvaranja novih pitanja, poput problema kategorije čestica unutar sintakse ili problema procesa gramatikalizacije.

Neutralnost pri zadovoljavanju istinitosnih uvjeta bilo bi treće obilježje diskursnih oznaka. Naime, DO-e semantički ne doprinose propozicijskom sadržaju iskaza, pa tako ni njegovim istinitosnim uvjetima.

Promjenjiva distribucija u diskursu sljedeća je karakteristika DO-a, iako je inicijalni položaj u iskazu često percipiran kao dominantan. Pretpostavljamo da je tomu tako jer se (između ostalog) diskursne oznake upotrebljavaju za svrhe omeđivanja i preoblikovanja željene interpretacije iskaza. Nasumičan raspored izraza iz ove kategorije prilično je rijedak i neuobičajen, no ako do toga dođe, često je riječ o poštapalicama i popunjivačima diskursa, o čijim će obilježjima biti rječi nešto kasnije (poglavlje 5). Naposljetku, nizanje diskursnih oznaka nije rijetkost.

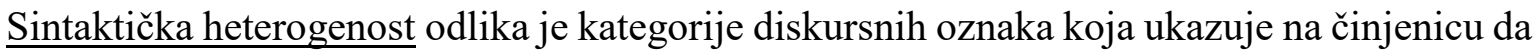
se ovdje radi o funkcionalno determiniranoj klasi rječi. O pragmatičnoj kategoriji jezičnih izraza u koju mogu ući sve formalne vrste riječi: glagoli, pridjevi, imenice, zamjenice, veznici, uzvici itd., ako obnašaju odgovarajuću funkciju na diskursnoj razini.

No uz navedena obilježja koja su se ponajprije ticala sintakse i semantike, nikako se ne smije zaboraviti razina leksika, prozodije, stilistike i sociolingvistike.

Leksička raznolikost ove kategorije očituje se u tome što DO-e mogu doći u obliku mikrooznaka (npr. popunjivač $\mathrm{hm}$ ), iz različitih izvora (npr. iz engleskog jezika), ali može biti riječ o čitavim frazama, tj. makrooznakama (u cyber-komunikaciji često u vidu akronima, npr. kjznm od Kaj ja znam).

Prozodijska izdvojenost ove skupine izraza također je vrlo učestalo obilježje kategorije, a odnosi se na činjenicu da diskursne oznake tvore zasebnu intonacijsku cjelinu u odnosu prema 
ostalim dijelovima iskaza. Drugim riječima, one su prozodijski samostalne i često se omeđuju pauzama ili ističu na neki drugi način. No što se događa ako je jezična razmjena isljučivo pisana? Da bi na ovo odgovorili, korisno je pogledati što se zbiva u cyber-komunikaciji (kao u razmjeni instant poruka), kada ne postoji mogućnost prenošenja dodatnih informacija s pomoću pauze, naglašavanja, intonacije i/ili neverbalne komunikacije u klasičnom smislu. Ono do čega je ovdje došlo jest prebacivanje prozodijskih odlika u grafički oblik. Pauze se pišu zarezima, trotočjima, dodatnim prazninama ili crticama, naglašavanje se obilježava masnim slovima, velikim slovima, razdvojenim velikim slovima i sl., a neverbalni aspekti komunikacije emotikonima, emojiima i didaskalijama (vidi poglavlje 3.4).

Naposljetku, kolokvijalna stilska upotreba i kontekstualiziranje iskaza tipična su obilježja komunikacije u kojoj se javljaju diskursne oznake, a to se manifestira njihovom visokom frekvencijom i raznovrsnošću upotrebe, ponavljanjem, nizanjem i oralnošću diskursa. U cyberkomunikaciji to se često manifestira fonetskim, tj. grafemskim pojednostavljivanjem, tj. nastankom kratica (npr. različitih akronima poput $L N$ umjesto Laku noć ili okrnjenih izraza poput aj! umjesto hajde!, neam umjesto nemam i sl).

Formalni kriteriji pokazali su se iznimno korisnima za dijakronijski pristup diskursnim oznakama. S druge strane, funkcionalni kriteriji pokazali su se korisnijima kod proučavanja ovih jedinica u sinkroniji.

\section{3. Funkcije i vrste diskursnih oznaka}

Funkcionalni je kriterij najrelevantniji, najkorisniji i vrlo logičan odabir za određivanje skupine jezičnih izraza poput diskursnih oznaka. Jedan je od razloga tomu njihova pragmatična priroda, a drugi njihova multifunkcionalnost koju uočavaju i spominju brojni autori, tj. odražava se u njihovim definicijama diskursnih oznaka i podjelama istih u potkategorije. No iz svih se teorijskih modela, bez obzira na razlike i razinu njihove kompleksnosti, može izdvojiti pet osnovnih funkcija DO-a koje primjećuje Dolić (2016: 44): označavanje diskursa, povezivanje, ograničavanje zaključivanja, iskazivanje stava i signaliziranje društvenih odnosa.

Nadahnuti ovom podjelom, predložili bismo vlastitu, s nešto drugačijim nazivljem i određenim modifikacijiama. Funkcije diskursnih oznaka bile bi sljedeće: komunikacijska 
(označavanje diskursnih/komunikacijskih funkcija), tekstno-diskurzivna (održavanje diskursne strukture), logičko-pragmatička (ograničavanje interpretacije govornikova značenja), sociokulturna (koordiniranje društvenih odnosa). Iz predložene je podjele izostavljena funkcija iskazivanja stava kao zasebna kategorija jer iskazi tog tipa mogu biti svrstani ili pod prvu ili pod treću funkciju.

Četiri navedene funkcije diskursnih oznaka mogu se objediniti pod dvije nadfunkcije, jer se prve dvije funkcije (komunikacijska i tekstno-diskurzivna) odnose na samu diskursnu strukturu, dok se posljednje dvije (logičko-pragmatička i sociokulturna) odnose na interakcijski element komunikacije. Stoga možemo reći da diskursne oznake u pravilu obnašaju dvije elementarne nadfunkcije: tekstualnu (diskurzivnu) i interpersonalnu (interakcijsku). Navedeno su obilježje primjetili i drugi autori (Brinton 1996, Marcela i Castro 2009). Također, nije na odmet spomenuti da jedna diskursna oznaka istovremeno može obnašati više navedenih funkcija.

\subsubsection{Komunikacijske funkcije}

Ove bismo funkcije, pa tako i podvrste diskursnih oznaka koje iz nje proizlaze, najbolje mogli shvatiti kroz Jakobsonove funkcije jezika i dijelove komunikacijskog lanca (Jakobson 1966). Naime, svaka diskursna oznaka odgovara nekoj od jezičnih funkcija, od kojih prema Jakobsonu imamo 6: ekspresivnu, konativnu, fatičku, referencijalnu, poetsku i metajezičnu. Svaka se od funkcija usmjerava, tj. odnosi na određeni dio komunikacijskog lanca: ekspresivna na govornika/pošiljatelja poruke, konativna na sugovornika/primatelja poruke, referencijalna na kontekst, fatička na komunikacijski kanal, poetska na poruku, a metajezična na kod. ${ }^{44}$ Da bi se određene funkcije istaknule, često se za manipulaciju diskursom upotebljavaju diskursne oznake, koje (kao što im samo ime govori) označuju i ističu neku sastavnicu diskursa, tj. dio komunikacijkog lanca.

Stoga bi diskursne oznake u ekspresivnoj funkciji naznačavale da je fokus na govorniku (npr. iskazivanje stava/osjećaja s pomoću uzvika i imitativa - khm, joj, uff, jeej), diskursne oznake u konativnoj funkciji ticale bi se sugovornika (npr. govorni činovi u tipu direktiva, poput - slušaj, ček), a one s istaknutom referencijalnom funkcijom odnosile bi se na kontekst, tj.

\footnotetext{
${ }^{44}$ Sam Jakobson nadodao je posljednje tri funkcije u svoj model, kojim je zapravo razradio model komunikacije Karla Bühlera, tzv. organon model. To je učinio umetanjem još triju elementa u komunikacijski lanac (uz govornika, sugovornika i kontekst): kod, kanal i poruku.
} 
kontekstualiziranje komunikacije (npr. u vidu didaskalija, deiksa i konektora - pusa, LOL, ovaj, ovako, dakle, a). Fatička bi se funkcija ostvarila diskursnim oznakama koje služe uspostavljanju i održavanju komunikacije. Ovdje se stoga mogu svrstati fatički izrazi kojima se otvara komunikacija i provjerava kanal (npr. heeej, kaj ima?, si tu?), izrazi koji služe za približavanje sugovorniku (npr. kaj ćeš, jbg, kužiš, znaš). Uz njih, ovdje bi potpale i oznake povratne informacije (npr. ok, dobro, može, aha) i oznake poticanja komunikacije (npr. kj ne?, ne, ok?).

S obzirom na nedostatak semantičkog sadržaja u kategoriji diskursnih oznaka, teško je govoriti o njihovoj poetskoj funkciji. S druge strane možda ih upravo ta značajka čiste pragmatičnosti i upravljanja interpretacijom nekog iskaza čini zanimljivima za proučavanje $\mathrm{s}$ aspekta stilistike i teorije književnosti. Na ovu bi se skupinu mogla odnositi podvrsta diskursnih oznaka kao što su popunjivači (npr. hmm, ..., kaj ja znam, mislim), koji stvaraju specifičan tijek i stil razgovora. Na kraju, ako u obzir uzmemo slučaj poštapalica kao potencijalne podvrste ovih diskursnih oznaka ili pak degenerirane upotrebe popunjivača, na njih možemo gledati kao na ostvarenje privatnog jezika, kao na svojevrstan idiomatski govor.

Naposljetku, diskursne oznake koje bi se odnosile na kôd ticale bi se multimodalnog i multilingvalnog aspekta komunikacije na mreži i predstavljale bi metajezičnu funkciju. S obzirom na činjenicu da u slučaju cyber-komunikacije kôd nije isključivo jezik, a dominantan jezik mreže jest engleski, javljaju se nove brige. Stoga, da bi se utvrdilo koji će kod(ovi) biti korišten(i) u sklopu komunikacijskog događaja i kako, sudionici se često koriste (samo)ispravljanjem (često je riječ o lapsusima radi brzine ili nepoznavanja koda) i ukazivanjem na tip informacijskog kanala (npr. vidi ovo, gle, znači).

\subsubsection{Tekstno-diskurzivna funkcija}

Ova se funkcija odnosi na obilježje vezivnosti dikursnih oznaka, točnije na diskursnu kohezivnost i koherentnost. S time na umu, ako bismo govorili o vrsti, tj. podskupini diskursnih oznaka, ovdje bi bila riječ o konektorima. Kao što navodi Nigoević (2010: 134):

„Konektori su oznake koje semantički i pragmatički povezuju jedan segment diskursa s prethodnim segmentom ili s nekom kontekstualnom pretpostavkom koja je lako dostupna. Njihova je funkcija da upućuju na logičke (smisaone) odnose između segmenata diskursa i da upozoravaju na povezanost $i$ sređenost raznih dijelova diskursa, čineći ga na taj način jasnijim.“

Autorica nadalje vrlo detaljno razrađuje ovu skupinu diskursnih oznaka, dijeleći je na potskupine (konektore dopune, posljedica i zaključivanja, suprotnosti i pojašnjenja) koje više- 
manje odgovaraju osnovnim logičkim operatorima i podjelama veznika u tradicionalnim gramatikama. Drugim riječima, pod konektore dopune obično spadaju sastavni veznici, pod konektore posljedica i zaključivanja zaključni veznici itd.

\subsubsection{Logičko-pragmatička funkcija}

Ova bi se funkcija diskursnih oznaka najbolje mogla objasniti s pomoću teorije implikatura H. P. Gricea ili s pomoću teorijskog pristupa problemu DO-a autorice Diane Blakemore.

Kao što je navedeno u prethodnim poglavljima, spomenuti su autori pristupali jezičnim problemima kroz prizmu pragmatike i bavili su se prirodom ljudske komunikacije, procesima zaključivanja i interpretacije govornikova značenja. Ono što su primjetili jest da je razgovor kooperativno i racionalno usmjereno djelovanje, da je iznimno ovisan o kontekstu, da njime uz propozicijski sadržaj prenosimo i druge sadržaje, te da se to odvija na eksplicitan i implicitan način. Ipak, da bismo bili shvaćeni od sugovornika, moramo ograničiti mogućnosti interpretacije naše poruke ne bi li on/a točno interpretirao/la našu namjeru. Upravo u tom ograničenju mogućih interpretacija, tj. u ograničavanju mogućeg broja zaključaka o nekom iskazu pomažu diskursne oznake.

U potskupinu diskursnih oznaka ove funkcije ubrojili bi se stoga svi kontekstualni „migovi“ koji prenose komunikacijsku intenciju (namjeru) s ciljem pobuđivanja procesa zaključivanja ili s ciljem vraćanja procesa inferencije na pravi smijer.

\subsubsection{Sociokulturna funkcija}

Kao što joj sam naziv govori, sociokulturna funkcija prenosi nam informacije o sociolingvističkim varijablama poput: vrste socijalnog odnosa, spola, dobi, rase, klase, vjerske pripadnosti itd. Diskursne oznake s istaknutom socokulturnom funkcijom često mogu služiti i kao tzv. „podmazivači” određene interakcije jer smanjuju poteškoće u razumijevanju, neslaganje i društvenu distancu. Drugim riječima, one pomažu ostvarenju kako tekstne, tako i društvene koherentnosti. 


\section{4. Diskursne oznake cyber-komunikacije}

S ciljem razjašnjenja podjele diskursnih oznaka s obzirom na funkcionalni kriterij svaka će podvrsta biti objašnjena na temelju primjera iz svakodnevnog govora u komunikaciji na mreži.

S obzirom na prethodno navođenje funkcija, podjelu diskursnih oznaka mogli bismo prikazati na sljedeći način:

\begin{tabular}{|c|l|l|}
\hline \multicolumn{2}{|l|}{ Tablica 3: Funkcije i vrste diskursnih oznaka } \\
\hline Nadfunkcije & Funkcije & Vrste \\
\hline \multirow{3}{*}{$\begin{array}{c}\text { tekstualne (diskurzivne) } \\
\text { funkcije }\end{array}$} & referencijalna/kontekstualna & \multirow{2}{*}{ konektori i popunjivači } \\
\cline { 2 - 2 } & poetska/stilska & \\
\cline { 2 - 2 } $\begin{array}{c}\text { interpersonalne } \\
\text { (interakcijske) funkcije }\end{array}$ & metajezična & \multirow{2}{*}{ interaktivi i modifikatori } \\
\cline { 2 - 2 } & fatička & \\
\cline { 2 - 2 } & konativna & \\
\hline
\end{tabular}

\subsubsection{Konektori i popunjivači}

Konektori i popunjivači kao prve dvije podvrste diskursnih oznaka, u osnovi imaju zajednička obilježja uređivanja diskursa i održavanja diskursne strukture. Kod konektora i popunjivača u prvom se planu nalazi tekstualna (diskurzivna) funkcija koja se manifestira diskursnom kohezivnošću i koherentnošću. Drugim rječima, o konektorima i popunjivačima ovisi gramatička fluidnost te semantička povezanost i smislenost teksta. Najistaknutiji dijelovi komunikacijskog lanca (pri upotrebi konektora i popunjivača) bili bi kontekst, sama poruka i kod, te njima sukladne funkcije jezika: referencijalna/kontekstualna, fatička i poetska/stilska funkcija. 


$\begin{aligned} & \text { Primjer 7: Konektor ono upotrebljen je radi kontekstualiziranja prenesenog } \\ & \text { sadržaja, uvođenja opisa situacije s pomoću deiktičnog izraza. U ovom slučaju } \\ & \text { zamjenica ono u službi je konektora nakon kojeg dolazi pojašnjenje, kao u slučaju } \\ & \text { klasičnih veznika poput dakle ili glagola značiti (tj. znači) u funkciji diskursne } \\ & \text { oznake. }{ }^{45} \text { Ovdje bi stoga bila riječ o naglašavanju referencijalne funkcije. }{ }^{46}\end{aligned}$
J: Jesu makar dobri ti sendviči? (:)
T: Ne!! Ahahahah al svuda po gradu, ono, klopa i cuga, ko neke birtije, i ili sendvic ili tortilla
T: Pa ti biraj
T: Ahahahah
T: I njima je to bomba
T: Uopce nemaju potrebu za necim drugim

Primjer 8: Primjer konektora dakle upotrebljen je sa svrhom pojašnjenja prethodno poslanog
medijskog sadržaja u vidu fotografija i tipičan je za multimodalnu komunikaciju. Iz
primjera je također vidljivo miješanje kodova, posebice utjecaj engleskog jezika
koji dominira sferom cyber-diskursa. ${ }^{47}$

Primjer 9: Primjer konektora $a$ ubačenog na početak iskaza s ciljem naglašavanja suprotnosti u odnosu na sadržaj prethodnog diskursa, ali i s ciljem nadovezivanja na isti. ${ }^{48}$

T: Bio bi gori spot na krovu sa rostilja

T: Ahahahah

J: Ahahahah

$\mathbf{J}$ : A glavno da sam ja rekla da je bas lijepo bilo na rostilju

\footnotetext{
${ }^{45} \mathrm{U}$ primjeru je moguće napraviti supstituciju izraza ono s izrazom dakle ili znači, i vidjet ćemo da je značenje iskaza ostalo nepromijenjeno.

${ }^{46}$ Prikaz izvornog primjera nalazi se u prilozima, prilog 7.

${ }^{47}$ Originalni prikaz razgovora dostupan u prilozima, prilog 8.

${ }^{48} \mathrm{Za}$ originialan prikaz razgovora vidi prilog 9.
} 


\begin{tabular}{|l}
$\begin{array}{l}\text { Primjer 10: Primjer popunjivača } h m \text { ubačenog u iskaz s ciljem dobivanja na vremenu za } \\
\text { razmišljanje. Ovom se diskursnom oznakom također izražava stav (obično sumnja) } \\
\text { te može biti u funkciji signalizacije držanja reda u govorenju, davanjem do znanja } \\
\text { našem sugovorniku da još razmišljamo o temi. }\end{array}$ \\
$\begin{array}{l}\text { T: Ima Filipi jeep, i prikolica } \\
\text { J: Ak krene padat, nis ni od prikolice... hm, sretno s tim svim }\end{array}$ \\
\hline
\end{tabular}

Da sažmemo, u potskupinu diskursnih oznaka s izraženom tekstualnom (dikurzivnom) funkcijom spadaju konektori i popunjivači. Obje skupine u sebi imaju izraženo svojstvo vezivnosti i time pomažu pri ostvarenju kohezivnosti i koherentnosti teksta (u bilo kojem obliku). Također, konektori se zbog strukturiranja diskrusa često nalaze u inicijalnim položajima iskaza zbog signaliziranja foričkih odnosa (često upotrebom deiksa) na nadrečeničoj razini. S druge strane, popunjivače nalazimo nasumično rasprostranjene kroz iskaz jer popunjavaju praznine, čineći diskurs povezanijim i često stilski obilježenim.

\subsubsection{Interaktivi i modifikatori}

Interaktivi i modifikatori, kao posljednje dvije podvrste diskursnih oznaka, dijele bazičnu funkciju koordiniranja interakcije (interpersonalnih odnosa) kroz komunikacijski proces. U njima i njihovom upotrebom reflektira se i formira socijalna struktura određenog diskursa, društveni odnosi, a njihov onovni potencijal leži u stvaranju socijalne kohezivnosti ili distance kroz komunikacijski događaj.

Za potskupinu interaktiva bila bi vezana konativna jezična funkcija koja se odnosi na govornika i fatička funkcija koja ističe važnost kontakta, tj. kanala. Ovdje bi se stoga ubrajali govorni činovi u tipu direktiva, vokativi (konativna funkcija), te pozdravi, retorička pitanja, provjere razumijevanja, potvrde sudjelovanja i slično (fatička funkcija). Interaktivima se obično ispoljava sociokulturna funkcija. 


\begin{tabular}{|l}
\hline Primjer 11: Na početku ovog primjera imamo interaktivnu oznaku hej, u službi otvaranja \\
razgovora, u obliku formulaičnog izraza (pozdrava) sa svrhom ostvarenja kontakta \\
(fatička funkcija). Nakon toga slijedi konektor nego koji strukturira razgovor \\
pomičući fokus na temu od interesa. Glagol daj govorni je čin (direktiv) koji \\
usmjerava iskaz na sugovornika (konativna funkcija), jednako tako to je slučaj s \\
ček. Čestica ma spada pod modalne oznake (modifikatore), čiji je osnovni cilj \\
prenijeti govornikov stav o sadržaju njegova/njezina vlastita iskaza. Time se ističe \\
ekspresivna/emotivna komunikacijska funkcija jezika i usmjerava sugovornikovo \\
zaključivanje o značenju iskaza. \\
\\
J: Hej! Sori kj gnjavim, uzivaj u sunji \\
J: Nego daj mi posalji koju fotku sanka od doceka (ja nisam nis pofotkala) \\
JS: Ma nisu nes fotke, cek \\
JS: medijski zapis (fotografija) \\
JS: medijski zapis (fotografija)
\end{tabular}

Na posljetku, modifikatori bi se odnosili na ekspresivnu, tj. emotivnu funkciju, a time i na govornika koji je njome stavljen u prvi plan. Njima se obično sugovorniku sugerira stav samog govornika prema sadržaju komunikacijske razmjene i time upućuje sugovornika na željenu interpretaciju iskaza. Iz tog razloga možemo zaključiti da se tom podvrstom modifikatora kao diskursnih oznaka manifestirala logičko-pragmatička funkcija kategorije. Naposljetku, na to nas upućuje i Sesar (2001: 204) u svom obrazloženju modalnosti:

„Modalnost u širem smislu općenito se definira kao trostruk odnos - odnos između kazivača (njegove intencije), sadržaja iskaza (iskaz kao jedinica govora na jezičnom planu odgovara rečenici) i zbilje (obuhvaćene sadržajem iskaza). U tumačenju modalnosti načelno se razlikuju dva polazišta: jedno je pozicija (nakane) kazivača, tj. njegov mogući odnos prema zbilji, a drugo je način iskazivanja određenog sadržaja, koji se očituje u načinu oblikovanja iskaza. Iz teorijskih razmatranja proizlazi da kriterij kazivačeve nakane naglašava moguća značenja sadržaja njegova iskaza i smješta pitanje modalnosti u semantički plan, dok način iskazivanja određenog sadržaja i oblikovanja iskaza prenosi modalnost na formalno-sintaktičku razinu." 


\begin{tabular}{|l}
\hline Primjer 12: U ovome se primjeru također mogu primijetiti različite vrste diskursnih oznaka. Na \\
samome početku imamo čitav iskaz sastavljen od zaredanih diskursnih oznaka, pri \\
čemu je čestica eto konektor u vidu prostorne deikse koja predstavlja anaforu (tiče \\
se prethodnog odsječka diskursa). Svašta se ovdje također ponaša kao diskursna \\
oznaka, ne kao neodređena zamjenica i zapravo nam prenosi govornikov stav \\
prema prethodnom sadržaju, te time postaje modifikator. Na posljetku, glagol \\
kužiš (ponekad skraćeno ku'išs) obnaša funkciju interaktiva, ističući fatički element \\
komunikacije. Njime se od sugovornika zahtijeva povratna informacija, provjerava \\
razumijevanje i održava informacijski tijek.
\end{tabular}

Uz ovakav, ponajviše pragmatički i tekstno-lingvistički pristup diskursnim oznakama, posebice u primjerima iz svakodnevne, neformalne i „oralizirane” komunikacijske razmjene, dobro može poslužiti i konverzacijska analiza koja ističe interpersonalni, tj. interakcijski element.

Po mišljenju Harveya Sacksa i njegovih suradnika (Liddicoat 2007: 54), red u govorenju čine njegove tvorbene jedinice, tzv. turn constructional units (TCU), koje mogu biti bilo koja lingvistička sastavnica: riječ, sintagma, fraza ili čitava rečenica. TCU može biti završen na tri načina: sintaktički, paralingvistički i pragmatički, a do potencijalnih završetaka dolazi na mjestima prijelaza važnosti, tzv. transition relevance places (TRP). Kod svakog mjesta prijelaza važnosti moguća su dva načina na koje govornik može preuzeti red u govorenju, tj. pisanju: trenutni govornik može odabrati sljedećeg, može doći do samoodabira ili držanja riječi. S obzirom na činjenicu da korisnici nisu u mogućnosti da vide i čuju jedan drugoga pri razmjeni instant poruka, odabir sljedećeg govornika ili samoodabir (kao i držanje riječi) signalizira se upotrebom emotikona, katafora, adresivnosti, tj. oslovljavanjem željenog sljedećeg govornika imenom (karakteristično za grupne razgovore ili forume).

Otvaranje reda u govorenju diskursnim oznakama oprimjereno je pozdravima i govornim činovima u vidu interaktiva, deiktičnim izrazima koji signaliziraju foričke odnose, a javljaju se $\mathrm{u}$ vidu konektora, te modifikatorima u inicijalnom položaju. Vrlo slično otvaranju reda u govorenju funkcionira i zatvaranje reda u govorenju, no ovdje je čest slučaj korištenja fatičke funkcije formulaičnim izrazima (poput retoričkih pitanja i frazema) i zahtijevanjem/dobivanjem 
povratne informacije (informacije o razumijevanju i uključenosti u komunikaciju). Zadržavanje pažnje, ali i reda u govorenju oprimjereno je dikursnom oznakom ček u primjeru 11.

Probleme preklapanja pri razmjeni instantporuka korisnici rješavaju na nekoliko mogućih načina: foričkim odnosima (referiranjem na nešto već rečeno ili nešto što će tek biti izrečeno), ponavljanjima, povezivanjem kroz adresivnost (npr. @ Sanja ili Htjela bih odgovoriti na Sanjin komentar.) i citiranjem. Suprotno tome, praznine u razgovoru često se nadomještaju trotočjima ili popunjivačima (fillers).

Naposljetku, problem popravljanja pogrešaka u razgovoru jednak je onome u govorenoj komunikaciji, no korinici nemaju naviku (samo)ispravljanja ako je sadržaj i dalje razumljiv iz konteksta. To se obično čini na već uvriježen način u sklopu cyber-komunikacije, upotrebom asteriska uz ispravljen izraz.

\subsubsection{Opis uzorka - ciljni (privatni) korpus i referentni korpus hrWac}

Danas je korpus nezaobilazan izvor prikupljanja podataka o svim jezičnim razinama. Iako se češće istražuju morfosintaktičke pojavnosti, kao i leksikon, sve se više ukazuje korisnost rada na korpusima i za područje pragmatike, tj. za proučavanje pojavnosti na diskursnoj razini. Ipak, prije daljnje analize vrlo je bitno definirati sam pojam korpusa, jer oni predstavljaju izvor primjera u ovome radu.

Za razliku od definicija diskursnih oznaka, definicije korpusa uvelike se podudaraju. Etimologija riječi korpus upućuje na latinski naziv za tijelo, tj. corpora, čime se sugerira cjelovita zbirka podataka, građe ili dokumenata za određenu disciplinu. Prof. Marko Tadić (1998.) nam također nudi svoje viđenje korpusa kao zbirke jezičnih odsječaka odabranih i skupljenih prema eksplicitnim lingvističkim kriterijima s ciljem da čine jezični uzorak. Pri tome Tadić naglašava kako korpus ne moraju sačinjavati cjeloviti tekstovi, nego i dijelovi tekstova koji su dovoljno veliki da čine korpusni uzorak. Naposljetku, bitno je imati na umu činjenicu da su u današnje vrijeme korpusi većinom digitalizirani, tj. kada se o njima govori misli se na računalne korpuse, tj. na korpuse kodirane na standardan i dosljedan način kojima je osnovna svrha otvorenost za računalno pretraživanje.

Korpusi se mogu međusobno razlikovati na temelju brojnih kriterija, no u općenitom smislu distinkcija se može napraviti među korpusima različitih jezika, njihovom opsegu specijalizacije 
i vrsti korištenih komunikacijskih kanala. Potom se razlikuju i korpusi određeni specifičnim vremenskim periodom, te prema načinu prikupljanja podataka.

Stoga, s obzirom na jezični kriterij možemo govoriti o jednojezičnim ili višejezičnim korpusima. U slučaju korpusa korištenih za potrebe ovog rada, riječ je o jednojezičnim korpusima hrvatskog jezika. Govoreći o parametru specijalizacije korpusa, oni mogu biti opći i specijalizirani. Opći korpusi nisu ograničeni određenim tematskim područjem ili registrom, već se njihovim sadržajem nastoji na reprezentativan način predočiti sveopće jezično bogatsvo. Najbolji primjeri takvih korpusa bili bi korpusi nacionalnih jezika poput Britanskog, Američkog, Ruskog i Hrvatskog nacionalnog korpusa. S druge strane, specijalizirani korpusi sačinjeni su od jezičnog materijala ograničenog žanrom, područjem djelovanja i specifičnom inačicom jezične izvedbe, stoga bismo u ovu kategoriju mogli svrstati ovdje korištene korpuse koje određuje kontekst cyber-svijeta i neformalnost svakodnevne komunikacije. Nadalje, korpusi se mogu razlikovati s obzirom na kanal, prema čemu se dijele na korpuse pisanog i korpuse govorenog jezika. No u ovu bismo podjelu uveli i korpuse iz cyber-komunikacije koje odlikuje oralizirani tekst i multimodalnost. Ako pak govorimo o klasificiranju korpusa s obzirom na vremensko razdoblje koje pokrivaju, možemo razlikovati sinkronijski od dijakronijskog korpusa. Također, režim prikupljanja podataka nekog korpusa govori o tome hoće li on biti dinamičan ili statičan, tj. hoće li se u njemu podaci redovno ažurirati ili ne. Ako posljednja dva kriterija primijenimo na korpuse upotrebljavane u ovome radu, možemo govoriti o sinkronijskim, ali dinamičnim korpusima. Naposljetku, postoje referentni i ciljni korpusi (engl. reference and target corpus) čije je razlikovanje ovdje također relevantno jer se ovom diferencijacijom razjašnjava odnos privatnih korpusa razmjene instantporuka i hrWaca korištenih za potrebe ovog istraživanja. Referentni je korpus u ovom slučaju hrWac, a služi za provjeru točnosti podataka i saznanja dobivenih analizom privatnog/ciljnog korpusa.

Hrvatski jezik pretraživ je na trima računalnim korpusima:

a) Hrvatska jezična riznica ${ }^{49}$ jest projekt Instituta za hrvatski jezik i jezikoslovlje, pokrenut 2005. godine. Kroz njega se oblikovao korpus tekstova hrvatskog jezika, svih struka i funkcionalnih usmjerenja, a cilj mu je pružiti osnovne informacije o hrvatskoj jezičnoj normi i hrvatskome jeziku općenito. Kronološki gledano, ovaj korpus sadrži tekstove od druge polovice 19. st. pa sve do danas, a obuhvaća temeljna

\footnotetext{
${ }^{49}$ Institut za hrvatski jezik i jezikoslovlje, Hrvatska jezična riznica. Dostupno na URL: http://riznica.ihjj.hr/dokumentacija/index.hr.html (13. 4. 2020.)
} 
djela hrvatske književnosti, publicistiku, znanstvene radove, udžbenike, prijevode, mrežni tisak i knjige iz predstandardnog razdoblja hrvatskog jezika koji su prilagođene današnjoj normi.

b) Hrvatski nacionalni korpus $(\mathrm{HNK})^{50}$ - projekt je započet 1998. godine, a danas postoji u inačici 3.0 beta, te broji 234 milijuna pojavnica. Ovaj korpus predstavlja zbirku suvremenih hrvatskih standardnojezičnih tekstova i pokriva različite žanrove, područja, medije i stilove. Dostupan je javno i bez naplate, u svrhu obrazovanja i (znanstvenih) istraživanja. Lematiziran je i morfosintaktički obilježen, a idejni mu je začetnik profesor dr. sc. Marko Tadić, predstojnik Katedre za računalnu lingvistiku, Odsjeka za lingvistiku Filozofskog fakulteta u Zagrebu.

c) Hrvatski mrežni korpus (hrWac) - za ovaj je rad najrelevatniji jer je korišten kao referentni korpus. Riječ je o mrežnom korpusu, tj. korpusu koji je sastavljen od tekstova preuzetih s interneta, s hrvatske nacionalne vršne domene, drugim riječima sa stranica koje na kraju adrese nose oznaku ,.hr“. Jednako kao i Hrvatski nacionalni korpus, hrWac je javno i besplatno dostupan putem No Sketch Engine programa, lematiziran je i morfosintaktički obilježen, te izgrađen na platformi Sketch Engine. S druge strane, za razliku od Hrvatske jezične riznice i HNK-a, hrWac ne sadrži „pročišćene“" tekstove, već sadrži velik broj tekstova (npr. pisanih razmjena s foruma ili blogova) u kojima postoji velik broj odstupanja od standardnojezične norme. Ovaj korpus stoga pruža uvid u svakodnevnu jezičnu upotrebu, u hrvatski vernakular, u jezičnu realnost na razini diskursa, te odgovara obilježjima ciljnog (privatnog) korpusa. HrWac je razvila skupina za obradu prirodnog jezika Odsjeka za informacijske i komunikacijske znanosti Filozofskog fakulteta u Zagrebu, a danas je dostupan u verziji 2.0 , te sadrži 1,9 milijardi pojavnica. ${ }^{51}$

Svi spomenuti korpusi računalni su, opći i potencijalno referentni korpusi, no hrWac se zbog svoje „nepročišćenosti” nametnuo kao najbolji kandidat za provjeru i utvrđivanje spoznaja dobivenih iz ciljnog korpusa.

Ciljni korpus ovog rada predstavljaju razgovori vođeni razmjenom instant poruka na mreži. Riječ je o dijalozima vođenim s pomoću nekih od danas najpopularnijih aplikacija za svakodnevnu komunikaciju: Whatsapp, Facebook Messenger i Hangouts. Njihovi su dnevnici (engl. message logs/log files) spremljeni u vidu statičnih bilježaka nizova instant poruka u

\footnotetext{
${ }^{50}$ Dostupno na URL: https://www.hr4eu.hr/croatia/hr/resursi/ (13.04.2020.)

${ }^{51}$ Dostupno na URL: http://nlp.ffzg.hr/people/ (13.04.2020.)
} 
izvorom redoslijedu i prikazane su kao takve na korisnikovu ekranu (Beißwenger 2008: 7). Spomenuta činjenica iznimno olakšava rad s materijalom jer ne zahtijeva dodatnu transkripciju (kao što bi bio slučaj kod snimki govorenog jezika i komunikacije licem u lice). Također, zbog digitalnog oblika u kojemu se korpus javlja, moguće ga je pretraživati alatima (poput tražilica rječi) koje olakšavaju i ubrzavaju analizu.

Nadalje, ciljni korpus iz kojeg su vađeni primjeri predstavlja razgovore koji su se odvijali između ženskih i muških osoba u rasponu od 30 do 40 godina starosti. Sve osobe koje su sudjelovale $u$ razgovorima poznaju se u privatnom životu, a njihovi se društveni odnosi mogu (u najširem smislu) definirati kao prijateljski tip odnosa. ${ }^{52}$ Opseg ciljnog korpusa zaokružen je sa 600 razgovora, no zbog ekonomičnosti i prirode same analize u radu su prikazani samo najreprezentativniji primjeri.

Razgovori koji čine ovaj korpus nastajali su sasvim spontano. Njihovi sudionici za vrijeme razmjene instant poruka nisu znali da će dnevnici razgovora naknadno biti podvrgnuti analizi. To se također odnosi i na autora ovog rada kao sudionika spomenutih razgovora, koji tek naknadno preuzima ulogu analitičara i interpretatora. ${ }^{53}$ Tek se nakon oblikovanja teme $\mathrm{i}$ osnovnih ciljeva ovog rada dnevnicima razgovora pristupilo kao korpusu koji je pružio izvrsno polazište za analizu i provjeru postavljenih hipoteza. Razgovor, kao jedinicu analize odredili smo prema vremenima slanja/primanja poruka. ${ }^{54} \mathrm{Na}$ taj se način, uz klasično otvaranje i zatvaranje razgovora moglo razdvojiti interakcije zabilježene u dnevniku/arhivi instant poruka.

Kriteriji kojima se navodilo pri odabiru spomenutih razgovora karakteristični su za kvalitativni tip istraživanja. Umjesto probablističkog i prigodnog uzorka koji se čitav podvrgava statističkoj obradi, ovdje su upotrebljeni namjerni uzorci kao iznimno pogodni za istraživanje sociopragmatičkih pojavnosti u jeziku, tj. kategorije, funkcije i svrhe diskursnih oznaka u cyber-komunikaciji. Osnovni bi kriteriji za formiranje ciljnog korpusa stoga bili sljedeći:

- upotreba diskursnih oznaka u svakodnevnom govoru na mreži, u njihovim različitim funkcijama i oblicima (s ciljem određivanja čitave kategorije diskursnih oznaka),

\footnotetext{
${ }^{52}$ Svi sudionici razgovora pristali su na to da se arhive razgovora analiziraju za potrebe ovog rada, no primjeri su u radu iz etičkih razloga ipak anonimizirani.

${ }^{53} \mathrm{O}$ etičkim problemima u podnaslovu koji slijedi.

${ }^{54}$ Softveri za razmjenu instant poruka obično posjeduju karakteristiku da bilježe vrijeme (sat i minute) u danu kada su poruke slane i primane, kao i dan (datum) razmjene.
} 
- problemi u komunikaciji uvjetovani medijem interneta (izostanak zajedničkog fizičkog konteksta) i njihovo rješavanje upotrebom diskursnih oznaka,

- inovacije u razgovoru (kao rješenje problema ili kao obogaćivanje interakcije) u rubnim jezičnim pojavnostima poput zapisanog parajezika, kraćenja čitavih fraza (npr. kjjznm) i grafičkih prikaza (npr. emojis) u službi diskursnih oznaka,

- evolucija i jezične promjene na razini diskursa uočljiva u procesu gramatikalizacije diskursnih funkcija (pragmatikalizacije).

$\mathrm{Na}$ ciljnom korpusu rađena je isključivo kvalitativna analiza materijala vezanih uz osobno iskustvo, prikupljenih tehnikom opažanja sa sudjelovanjem. Takva analiza dozvoljava dubinsku, neredukcionističku interpretaciju podataka, dok s druge strane na raspolaganju stoji referentni korpus hrWac koji osim što pruža mogućnost provjere pouzdanosti podataka, omogućuje kvantitavnu analizu zbog velikog broja pojavnica i automatizirane pretrage s pomoću računalnog programa (No Sketch Engine). On nam također pruža priliku za proučavanje koteksta u kojem se određene diskursne oznake javljaju (provjeravanje konkordancije). Primjeri iz $h r W a c-a$ analizirani su i prikazani u sljedećem poglavlju, u podnaslovu 5.2. Odabrani su na temelju podataka iz privatnog (ciljnog) korpusa, kao najčešći i najprototipniji oblici diskursnih oznaka neformalne cyber-komunikcije. Nakon (namjernog) odabira, jedinice su pretraživane u $h r W a c$-u, te je pomoću alata No Sketch Engine proučavana njihova konkordancija, položaji u diskursu i frekventnost pojavljivanja.

\subsubsection{Etičke reperkusije dvostruke uloge istraživača}

Ljudska komunikacija, tj. istraživanja provođena unutar tog područja u velikoj mjeri počivaju na premisi da se komunikacija među ljudima može opisati kao predmet. Međutim, komunikacija nije statičan objekt, već proces koji se sastoji od niza interakcija, te je stoga njezino proučavanje također dinamična aktivnost. Štoviše, mi kao bića koja komuniciraju proučavamo komunikaciju drugih i time postajemo dijelom predmeta kojim se bavimo. To je još više izraženo ako se bavimo komunikacijom između nas i naših sugovornika. Refleksivne odlike ljudske kominkacije upravo iz tih razloga ne bi smjele biti izostavljane u ime znanosti, već bi ih trebalo uključiti u istraživanja i njihova otkrića. Ipak, kada sami postanemo objektom vlastitog istraživanja, kao u našem slučaju, prelazimo konvencionalnu granicu koja oduvijek 
postoji između istraživača i predmeta istraživanja. Istraživač u takvim slučajevima preuzima dvostruki identitet, akademski i privatni, što ponovo na površinu izvlači dva vječna pitanja kvalitativnih participativnih istraživanja: pitanje objektivnosti i pitanje opasnosti da se promijeni predmet istraživanja zbog prisutnosti istraživača.

Naime, korpus koji predstavlja temelj za našu analizu sastavljen je od razgovora u kojima smo osobno sudjelovali kao jedan od sugovornika, dakle naša je uloga bila uloga sudionika u svakodnevnom razgovoru. No kao i ostali sudionici spomenutih razgovora, tada nismo bili svjesni činjenice da će naši iskazi i iskazi mojih sugovornika kasnije biti podvrgnuti nekoj vrsti analize. Odluka o analizi dnevnika instant poruka za potrebe ovog rada donesena je nakon nastanka samih razgovora. Tek s početkom analize dnevnika instant poruka naša se uloga u odnosu na korpus promijenila. Nekadašnji sudionik razgovora postao je analitičarom koji proučava vlastitu komunikaciju s drugima.

S obzirom na način prikupljanja materijala za analizu, položaj istraživača i pristupanje korpusu, naše istraživanje posjeduje obilježja nekolicine različitih pristupa koji se ubrajaju u kvalitativna istraživanja:

- Od autoetnografije preuzima specifičan položaj istraživača kao osobe s dvostrukim identitetom: akademskim i privatnim. No te se dvije uloge u našem slučaju nisu odigravale istovremeno. Za vrijeme nastajanja razgovora naša je uloga bila uloga sudionika u svakodnevnom i neformalnom razgovoru bez razmišljanja i znanja o njegovoj potencijalnoj analizi. Uloga analitičara pojavila se naknadno i odvijala se vremenski neovisno o prvoj ulozi.

- S radikalnim empirizmom dijeli činjenicu da istraživač postaje dijelom interakcije kojom se bavi. No uvijek prisutna opasnost kod sudjelujućeg promatranja - da će promatrač svojim sudjelovanjem promijeniti predmet istraživanja - ovdje ne postoji u tom smislu jer za vrijeme nastanka razgovora kao predmeta istraživanja sudionik nije bio i promatrač.

- Najbliže odgovara participativnom promatranju koje se odvija u prirodnim, nekontroliranim i dinamičnim uvjetima. Ipak zanimljivo je da se u našem slučaju s jedne strane sudionik može smatrati potpunim sudionikom, dok je u drugoj fazi istraživanja on „,̌isti” promatrač.

Naposljetku vratimo se problemu objektivnosti, tj. pitanju u kojoj je mjeri možemo očekivati pri ovakvoj vrsti analize, koliko je dobro inzistirati na objektivnosti i je li ona u potpunosti 
ostvariva? Naime, bilo da jezik upotrijebimo pri analizi sebe samih, bilo pri analizi drugih ili svijeta koji nas okružuje, uvijek dolazi do neodređenosti, nepreciznosti i zastranjenja od apsolutne objektivnosti. Naivno je gledati na jezik kao na posve neutralan i transparentan medij komunikacije, posebno u slučaju kada se njime koristimo kao glavnim oruđem pri analizi i interpretaciji predmeta kvalitativnog istraživanja. Upravo zbog činjenice da nije moguće $u$ potpunosti ukloniti utjecaj promatrača od promatranog, nijedna teorija ni otkriće ne mogu u potpunosti biti lišeni ljudskih vrijednosti. Nakon svega se opravdano možemo zapitati zašto ne bismo promatrali promatrača, zašto ne bismo fokus svog istraživanja prebacili i na sebe? Ono što je bitno jest da pri tome osvijestimo vlastitu neobjektivnost, naš specifičan položaj u odnosu na istraživano, u odnosu na sebe same, što nam pak može omogućiti dublje shvaćanje problema.

Možemo zaključiti da je ovo čitavo (četvrto) poglavlje bilo posvećeno diskursnim oznakama u sinkronijskom presjeku, u kontekstu komunikacije na mreži. Problematika je bila otvorena raspravom i odabirom adekvatne terminologije i formuliranjem zadovoljavajuće definicije diskursnih oznaka. Da bi se to postiglo, izdvojeni su formalni kriteriji nužni za određenje same kategorije u pitanju, ali još se veći značaj pridao funkcijama i vrstama diskursnih oznaka. Sve je demonstrirano na konkretnim primjerima iz cyber-komunikacije. Ipak, s ciljem boljeg razumijevanja čitave kategorije DO-a zaključili smo da isključivo sinkronijski pristup ovoj temi neće biti dostatan. Iz tog razloga u poglavlju koje slijedi donosimo i dijakronijske aspekte kategorije u pitanju te neke od značajnih doprinosa područja evolucijske pragmatike za šire područje lingvistike. 


\section{DISKURS I EVOLUCIJSKA PRAGMATIKA - jezični razvoj kao posljedica (u)potrebe}

Uvodnim riječima ovog poglavlja pružit će se kratak pregled područja evolucijske ${ }^{55}$ pragmatike, njezin povijesni razvoj i njezin značaj za šire područje jezikoslovlja. Nakon nekoliko povijesnih činjenica o ovom području, osvrnut ćemo se na makroprisutupe unutar evolucijske pragmatike. Riječ je o teorijama koje proučavaju specifične jezične promjene iz pragmatičke perspektive (primjerice teorija Traugott i Dasher: Invited Inference Theory of Semantic Change $\left.{ }^{56}\right)$, kao i onima koje razmatraju problem jezične evolucije u širem smislu, s naglaskom na upotrebi ${ }^{57}$. Uz makroteorije pozabavit ćemo se proučavanjem obrazaca specifičnih dijakronijskih procesa, pragmatičkim fenomenom mikrorazine, točnije razvojem diskursnih oznaka. Naposljetku, u duhu istinski zaokružene historijske pragmatike, nećemo zanemariti komunikacijski kontekst unutar kojeg je došlo do jezične promjene. U ovom slučaju radi se o kontekstu novih medija, tj. internetu koji će biti uzet u obzir pri svim teorijskim promišljanjima i analizama primjera, te koje ćemo njime nastojati povezati.

Pragmatizam, pragmatika, prilagodba i jezična evolucija povijesno su povezani $\mathrm{s}$ Darwinovom teorijom evolucije. Ta se povezanost na povijesnoj osi eksplicitno očitovala kroz rasprave tzv. „Metafizičkog kluba” na Harvardu koji se počeo okupljati 1872. godine, a prominentniji članovi su mu bili William James i Charles Sanders Peirce (Wildgen 2007: 81). Njihovo je osnovno polazište bilo shvaćanje pragmatike kao Darwinove teorije prirodnog odabira, koja se ovog puta primijenila na domenu filozofije umjesto na područje biologije. Ovakav pragmatizam, shvaćen kao filozofija zasnovana na praktičnim posljedicama intelektualnih (umnih) operacija, skicirao je i sam Peirce u svome govoru na Harvardu iz 1872.

Središnji pojam evolucijsko pragmatičkih rasprava pojam je prilagodbe, no (jezična) prilagodba ovdje se može pojaviti iz triju različitih razloga: zbog promjena okoline, zbog promjena u društvenoj organizaciji i kulturi i zbog uvođenja novih standarda jezične uporabe.

\footnotetext{
55 Također poznata pod imenom historijska pragmatika.

${ }^{56}$ Više o spomenutoj teoriji u Jucker (2017), te u podnaslovu 5.3. Jezične promjene na diskursnoj razini.

${ }^{57}$ Emergentizam kao perspektiva/pristup jezičnoj evoluciji, relevantnost utjelovljenosti i gestovne teorije jezičnog postanka, o čemu će biti više riječi u nastavku.
} 
Jasno je da se navedeni razlozi mogu i ispreplitati, a ako ih kao preduvjete primijenimo na suvremeni jezik i društvo, jezična će promjena biti vidljiva na razini cyber-diskursa jer su joj prethodila sva tri uvjeta: promjena okoline (prijelaz iz fizičkog svijeta u svijet na mreži), promjena sociokulturnih uvjeta (prijelaz u svijet anonimnosti, pseudoidentiteta i hiperpersonalnosti) i uvođenje implicitne jezične norme pri mrežnoj komunikaciji (cyberpismenost).

No vratimo li se na trenutak ponovno u povijest, u 1859. godinu kada je Darwin objavio svoje Porijeklo vrsta, uočit ćemo da je već postojao velik interes za porijeklo i evoluciju jezika. U godinama koje su uslijedile pojavio se čitav dijapazon teorija, no s obzirom na to da su bile zasnovane na brojnim spekulacijama i određene manjkom empirijskih dokaza, 1866. godine Societé de Linguistique de Paris stavilo je zabranu na sve rasprave na temu jezične evolucije i time ju je gotovo isključilo iz znanstvenog diskursa na više od jednog stoljeća (Christiansen i Kirby 2003: 300).

Među prvim teorijama koje su oživile interes za temu jezične evolucije i jezičnog postanka bila je teorija jezične sposobnosti Noama Chomskog koju odlikuje nativizam, tj. pretpostavka o urođenosti jezika. Predstavnici ove struje na predmet jezika gledali su i gledaju u užem smislu (engl. Faculty of Language in the Narrow Sense, tj. FLN). Drugim riječima, u obzir uzimaju isključivo apstrakntnu jezičnu jezgru, shvaćenu kao zbir računalnih operacija karakterističnih samo za ljudsku vrstu. Nedostatak ovog pristupa ogledao se u činjenici da zaseban jezični modul u mozgu nikada nije dokazan, a obilježje rekurzivnosti koje se nekoć smatralo differentiom specificom ljudske jezične sposobnosti i osnovnim adutom ovih teorija, dovedeno je u pitanje (Jackendoff i Pinker 2005) ${ }^{58}$. Također, sljedbenici čomskijanske perspektive (poput Davida Lightfoota ${ }^{59}$ ) u središtu ostavljaju sintaksu, vjeruju da se jezična promjena događa isključivo pri dječjem usvajanju jezika, što (ponovno) argumentiraju hipotezom o siromaštvu podražaja i jezičnom urođenošću. Nakon Chomskog, u okrilju iste paradigme veliku su prekretnicu napravili Pinker i Bloom (1990) jer su za razliku od Chomskog koji je pretpostavio jezični razvoj s pomoću makromutacija, predložili evoluciju prirodnim odabirom. Naposljetku,

\footnotetext{
${ }^{58} \mathrm{U}$ svome radu The Nature of the Language Faculty and its Implications to the Evoluition of Language (A Reply to Fitch, Hause \& Chomsky) Jackendoff i Pinker tvrde da rekurzivnost nije jezično specifična jer se može pronaći i u ljudskom vizualnom sustavu.

${ }^{59}$ Više o autoru na poveznici URL:

https://gufaculty360.georgetown.edu/s/contact/00336000014RgUnAAK/david-lightfoot (29. 6. 2020.)
} 
za razliku od čomskijanske univerzalne gramatike, Pinker je predložio tzv. jezični instinkt kao prilagodbu i pretpostavku za komunikacijsko djelovanje.

Nasuprot paradigmi nativizma stoji Darwinova (2000 [1872]) pretpostavka o razvoju ljudskog jezika iz općih kognitivnih procesa. Točnije, zastupnici ove perspektive smatraju da se ljudski jezik razvio iz životinjskog ekspresivnog i komunikacijskog ponašanja, a osnovu za taj razvoj po njihovu je mišljenju pružila upotreba i prilagodba. Spomenuta paradigma naziva se emergentizmom (ponekad empiricizmom i funkcionalizmom) i oblik je kognitivizma, no pridaje veliku važnost nelingvističkim čimbenicima poput memorije, pragmatike, društvene interakcije, fiziologije, percepcije i procesiranja. Karl Bühler (2011 [1934]) svojim se promišljanjima o problemu jezične evolucije vrlo dobro nadovezao na Darwina, a to je učinio s pomoću razine znakovnih (komunikacijskih) funkcija ${ }^{60}$. Bühler je pretpostavio da se kritična granica između ljudskog i životinjskog znakovnog ponašanja nalazi na razini znakovih funkcija. Autor je razlikovanjem triju osnovnih funkcija znakova u svojem Organon modelu (modelu komunikacije) - reprezentacije (njem. Darstellung) od ekspresije (njem. Ausdruck) i od apela (njem. Appell) - zaključio da je funkcija reprezentacije obilježje isključivo ljudskog jezika $^{61}$, dok se ostale dvije ostvaruju već i u životinjskoj komunikaciji. Wildgen (2007: 84) pretpostavlja da funkcije Bühlerova modela izviru iz ljudskog kategoriziranja okoline i iz društvenih kategorija te da zahtjevaju samo prvu razinu (auto)referencijalnosti i svjesnosti.

Po uzoru na Bühlerov model Jakobson je nešto kasnije razradio vlastiti komunikacijski model (spominjan u prethodnom poglavlju), dodavši mu još tri metafunkcije, funkcije koje su autoreferencijalne (poetsku, fatičku i metajezičnu) i koje zahtjevaju postojanje samosvijesti i metakognicije. Takvim se modelom pretpostavila biološka evolucija (razvoj mozga, motoričkih sposobnosti i neuroloških kapaciteta), kao i ona kulturološke prirode (razvoj društvenih struktura).

Ipak, svi se funkcionalni modeli komunikacijske evolucije za početak trebaju zapitati o vrijednosti komunikacije za opstanak vrste. Drugim riječima, pod kojim se uvjetima isplati (recipročno) dijeljenje informacija? Neki autori poput Robina Dunbara (1996) smatraju da odgovor leži u održavanju mira u zajednici, u održavanju društvene kohezivnosti ${ }^{62}$, dok drugi

\footnotetext{
${ }^{60}$ Jezične funkcije, tj. komunikacijske funkcije jezika obrađivali smo u prethodnom poglavlju. Ondje smo ih upotrijebili kao jedan od temelja za kategorizaciju diskursnih oznaka i pozvali smo se na Jakobsonov model sa šest funkcija koji je nastao po uzoru na Bühlerov model, tj. predstavlja njegov razrađeni oblik.

${ }^{61}$ Ako se reprezentacijska funkcija i pojavi u komunikaciji životinja, bit će iznimno ovisna o kontekstu.

${ }^{62}$ Takav se stav najbolje ocrtava u konceptu fatičkog zajedništa (engl. phatic communion) Bronislawa Malinowskog.
} 
autori poput Fehra i Henricha (2003) na razmjenu informacija gledaju kao na ekonomsku razmjenu koja određuje i određena je nejednakostima u društvenoj strukturi.

U novije su se vrijeme unutar emergentizma razvile dvije struje: jedna koja ističe značaj složenih spoznajnih struktura i njihova razvoja kao preduvjeta za jezični postanak i druga koja težište stavlja na složenu društvenu spoznaju, čiji je najprominentiji predstavnik Michael Tomasello (Bernabeu i Vogt 2015).

Naposljetku, postavljaja se pitanje semiološkog porijekla jezika: nalazi li se ono u glasu ili u gesti? Autori koji pretpostavljaju da je manualna gesta prethodila govoru, smatraju da je do prelaska $\mathrm{s}$ geste na govor došlo ili zbog povećane manipulacije oruđem ili kombinacijom vokalizacija s gestama. Kritičari spomenute gestovne teorije jezičnog porijekla ovdje ističu da manualne geste imaju velik nedostatak u odnosu na zvuk jer pretpostavljaju vizualni kontakt $\mathrm{s}$ osobom s kojom komuniciramo. Stoga perspektiva suprotna gestovnim teorijama pretpostavlja da se jezik razvio isključivo iz vokalne domene, iz zvukova poput mljackanja i sisanja, što se s vremenom razvilo u fonetske geste (Christiansen i Kirby 2003: 304).

Suvremena istraživanja jezične evolucije sve se više pronalaze u istraživanjima ljudskog genoma, što nam otkriva genetsku osnovu za jezik i spoznaju (npr. otkriće FOXP2 gena čija se mutacija smatra preduvjetom za komunikacjsku sposobnost). Također, sve su popularnija računalna modeliranja ljudskih kognitivnih sposobnosti (npr. neuroarheologija), a govorniku se počela pridavati važnost u proučavanju jezične evolucije jer se pokazalo da je jednako važan čimbenik u tom procesu kao i tijelo i okolina.

\section{5 .1. Od utjelovljene spoznaje prema bestjelesnoj komunikaciji}

Dugo se vremena na jezik (unutar lingvistike) gledalo iz strukturalističke perspektive obojene mentalizmom, pri čemu se jezik definirao i tretirao kao neutjelovljeni, apstraktni znakovni sustav. Utjelovljenost jezika, ekspresivnost, njegov interaktivni element i kapacitet izravnog djelovanja jezikom obično su ostavljani po strani i često su smatrani sporednima za jezičnu strukturu. Tek u posljednjih nekoliko dekada 20. stoljeća, istraživanjima u sklopu evolucijske antropologije (posebice proučavanjem dječjeg razvoja), kao i lingvističkim interdisciplinarnim istraživanjima, ponovno je istaknuta relevantnost jezične upotrebe kao i njezina nerazdvojivost od sustava i njegovih promjena. Pri tome je uvažen značaj neverbalne 
komunikacije (kao svojevrsne predjezičnosti) koja se otkriva u pojedincu prije konkretnog jezičnog usvajanja.

Ponovnim ukazivanjem na značaj sociopragmatičkih i psiholoških čimbenika za jezični sustav na dijakronijskoj osi, kao i priznavanjem relevantnosti neverbalne komunikacije u jezičnom razvoju, ponovno su se otvorile niše za teme jezične evolucije proučavane iz pravca historijske pragmatike. Ukorak s time otvorilo se novo poglavlje ljudske pismenosti usponom digitalnih tehnologija i komunikacije na mreži, što je ponudilo novi okvir i obilan korpus za istraživanje komunikacijskog razvoja i jezične evolucije. U sve brojnijim istraživanjima računalno-posredovane komunikacije, čiji se potencijal još otkriva, nastoje se potvrditi i demantirati kako suvremene tako i klasične teze. No ono što gotovo svi radovi pokazuju (a što ćemo i sami svojom analizom nastojati prikazati) jest da diskursna razina utječe na jezičnu strukturu, da se i na njoj odvijaju jezične promjene te da neverbalna komunikacija čini velik dio jezične i pred-jezične sposobnosti.

Kao što je primijetio i sam Darwin, ljudski oblik eskpresivne komunikacije jedinstven je u životinjskom carstvu i vrlo vjerojatno predstavlja osnovu za inicijalni razvoj verbalnosimboličkih oblika komunikacije u ranom djetinjstvu (Fuchs 2016: 108). Ono što je za takvu komunikaciju ključno jest da se već u prvim neverbalnim razmjenama pogleda, gesta, izraza lica i intonacije u djetetu razvija razumijevanje tuđih namjera. Intencije drugih koje se prve prepoznaju nužno su utjelovljene: vidljive, eskpresivne, orijentirane prema određenom cilju i popraćene gestama pokazivanja čije se značenje otkriva u kontekstu tjelesne interakcije. Spomenuta utjelovljenost komunikacije iznimno dolazi do izražaja u komunikaciji na mreži, iako je ona često (posebice u ranim istraživanjima) bila proklamirana kao neutjelovljena komunikacija par excellence. I zaista, s obzirom na to da na mreži nismo suprisutni kao u komunikaciji licem u lice, već samo teleprisutni: prisutni na daljinu, prisutni umom a ne tijelom, intuitivno bi se moglo zaključiti da je cyber-komunikacija neutjelovljena. Ipak, čovjek je utjelovljeno biće i čak kada se u komunikaciji izravno ne referira na tijelo, tjelesnost se otkriva u njegovu diskursu. U sklopu cyber-komunikacije ljudska utjelovljenost najočitije se manifestirala parajezikom, tj. zapisanom neverbalnom komunikacijom poput emotikona (engl. emoticon) koji su evoulirali u emođije (engl. emojis), iz čega se potom razvio jezik emođija.

Jezik je iz ove perspektive (teorijskog okvira utjelovljene spoznaje) ovisan o tjelesnosti u interkaciji, to jest tzv. interkorporalnosti koju Weiss (1999: 5) opisuje na sljedeći način: 
„To describe embodiment as intercorporeality is to emphasize that the experience of being embodied is never a private affair, but is always already meadiated by our continual interactions with other

human and nonhuman bodies."

Povezanost jezika i tijela u sklopu suvremene lingvistike među prvima su naglasili Lakoff $i$ Johnson svojim kapitalnim djelom Metaphors We Live By iz 1980., a posljednjih se godina ona često proučava iz perspektive utjelovljene i življene spoznaje (engl. Embodied and enacted cognition). Ova paradigma na spoznaju gleda kao na oblik interakcije između organizma i njegove okoline i ne čini razliku između viših i nižih kognitivnih funkcija. Po mišljenju autora ove struje: motorne, senzorne i kognitivne funkcije intermodalno su povezane, što je dalo poticaj istraživanjima jezika koja uključuju kineziku, proksemiku i propriocepciju u teorije jezičnog razumijevanja i produkcije. Također, u posljednje se vrijeme utjelovljenost jezika sve više potvrđuje otkrićima neuroznanosti koja pokazuju da je jezično procesiranje funkcionalno povezano sa senzomotornim sustavom, stoga značaj utjelovljenosti i neverbalne komunikacije za jezik, posebice za jezični razvoj, postaje neupitnim i zaslužuje dodatnu pažnju.

\subsubsection{Gestovna teorija jezičnog porijekla}

Zastupnici gestovne teorije jezičnog porijekla uviđaju i ističu relevantnost utjelovljene prirode jezika. Oni polaze od neposredne tjelesne interakcije koju smatraju izvorom i temeljem suvremenog jezika. Pretpostavljajući da sve kreće od geste pokazivanja i združene pažnje (engl. joint/shared attention ${ }^{63}$ ), smatra se da dolazi do formiranja sposobnosti iščitavanja tuđih namjera, pa tako i nastanka prvih zajedničkih značenja kao pretečā znaka. Daljnji rani razvoj neverbalne komunikacije obilježen je deiktičkim i ikoničkim gestama, primjerice gestama glavom za „da” i „ne”. Po mišljenju sociopragmatičara slijedi jezični razvoj koji je na jednak način ustrojen situacijama interkorporalnosti, združene pažnje i shvaćanja intencionalnog djelovanja drugih. Sve navedeno odvija se davanjem migova kroz primjere (engl. ostensive cueing), zbog čega je nerazdvojivo od konteksta situacije. Jednostavnije rečeno, prve su riječi povezane s već razumljivim gestama, posebice gestom pokazivanja (npr. Gle! Lopta!). Kao što navodi Fuchs (2016: 119), zastupnici ove teorije riječ percipiraju kao vokalnu gestu koja u početku samo nadopunjuje gestu pokazivanja kao izvorni znak. S druge strane, vokalizacija

\footnotetext{
${ }^{63}$ Pojam združene pažnje predstavlja zajedničku usredotočenost dvoje ili više pojedinaca na neki objekt, živo biće ili pojavu. Ona se postiže pobuđivanjem interesa u drugoj osobi s pomoću geste pokazivanja, usmjeravanjem pogledom ili drugim oblicima neverbalne i verbalne komunikacije. Združena je pažnja iznimno bitna kod prepoznavanja komunikacijskih namjera, stoga i za jezično usvajanje, procesiranje i produkciju.
} 
nekoć fizičku gestu odmiče od tijela, tjelesnosti i denotacije i odvlači je u svijet apstrakcije, arbitrarnosti i umnoženih značenja.

Ipak, ako se (proto)riječ zaista shvati kao vokalna gesta, otvorit će se brojne mogućnosti za istraživanja marginalno jezičnih pojava poput fonetskog simbolizma (onomatopejskih izraza) i fenomena šutnje kao značajnog i značenjskog elementa komunikacije. Štoviše, suvremena istraživanja ljudskog mozga i ljudske komunikacije sve nas više upućuju u tom smjeru. Povezanost različitih semioloških sustava sve se više otkriva, tako su primjerice neurobiološki nalazi pokazali da u ranom djetinjstvu mozak ne procesira glazbu i jezik u različitim domenama, već se jezik procesira kao poseban oblik glazbe. O tome nam govori Fuchs (2016: 120) ističući kako ta činjenica i nije toliko iznenađujuća jer su i jezik i glazba organizirani temporalno, imaju strukturu, obrasce, ritam, naglaske, intonaciju, fraze i oblik. Plauzibilnost ovih tvrdnji, tvrdnji o koevoluciji glazbe i jezika, ogleda se u emocionalnoj komunikaciji prozodijom kao osnovnim izvorom obaju sustava.

S vremenom se (kako kod razvoja dječjeg jezika, tako i kod jezične evolucije generalno) vokalna gesta odvojila od svojeg govorećeg subjekta i nekog specifičnog konteksta te je postala trećim elementom komunikacijskog događaja (uz govornika i sugovornika). Iako je često smatrano da se gesta postepeno sasvim gubi iz komunikacije, još je Merleau-Ponty (2004: 213) ukazivao da tomu nije tako:

„The spoken word is a genuine gesture, and it contains its meaning in the same way as the gesture contains its. This is what makes communication possible. In order that I may understand the words of another person, it is clear that his vocabulary and syntax must be 'already known' to me. But that does not mean that words do their work by arousing in me 'representations' associated with them, and which in aggregate eventually reproduce in me the original 'representation' of the speaker. What I communicate with primarily is not 'representations' or thought, but a speaking subject, with a certain style of being and with the 'world' at which he directs his aim."

Drugim riječima, jezik nije samo sustav reprezentacije, već transformirana gesta. Jezična se sposobnost ne razvija isključivo zbog genetske predispozicije, već zahtijeva kontekst, zajedničke strukture značenja i komunikacijsku praksu kako bi se razvila. Naposljetku, on je zasnovan na značenjima a značenja na utjelovljenim odnosima, stoga je i sam utjelovljen iako u sebi sadrži potencijal da se odmakne od tijela i tjelesnosti. Upravo ćemo se na taj fenomen detaljnije osvrnuti u podnaslovu koji slijedi. 


\subsubsection{Posredovana gesta - specifičnost cyber-komunikacije}

Cyber-prostor često je proglašavan medijem u sklopu kojeg i/ili s pomoću kojeg pojedinac može doživjeti bestjelesnost i time se osloboditi materijalnog svijeta realnosti. No je li to zaista tako? Što se zapravo događa s tijelom i problemom utjelovljene komunikacije u virtualnom kontekstu?

Istraživanja povezanosti cyber-prostora i obestjelovljenog sebstva nisu nova. Štoviše, rani radovi iz područja računalno posredovane komunikacije internet su percipirali kao idealan medij za obestjelovljenje, medij koji nam upravo zbog tog obilježja pruža brojne prednosti. Od tih prednosti najviše su se isticale anonimnost i impersonalnost s jedne strane, te umnažanje identiteta i hiperpersonalnost $\mathrm{s}$ druge strane spektra. Postojale su bojazni da će se zbog nedostatka suprisutnosti, tj. zajedničkog fizičkog konteksta umanjiti značaj komunikacije, da će ona postati gotovo automatizirana, hladna i bez socijalnog aspekta. S druge strane, neki su autori impersonalne aspekte cyber-komunikacije smatrali iznimno pozitivnima, ističući njihovu pogodnost za poslovnu komunikaciju koju impersonalnost čini produktivnijom. Ipak, porastom istraživanja komunikacije na mreži i samim razvojem novih medija dokazani su i suprotni učinci: ispostavilo se da na mreži, osim što dolazi do interpersonalnih interakcija, često dolazi i do pojačane interpersonalne komunikacije. Ovakva hiperpersonalnost (Walther 1996) nastaje zbog užitka koji nam pruža anonimnost, što rezultira izvođenjem (višestrukih) digitalnih identiteta.

Hiperpersonalnost se može shvatiti i kao oblik interpersonalnosti, svojevrsna pojačana interpersonalnost koja ističe značaj indentiteta (ili barem pseudoidentiteta), ali ga nikada ne nadilazi. Ona podrazumijeva utjelovljenu komunikaciju, ali njome ne uvjetuje tjelesnu suprisutnost. Štoviše, teleprisutnost je ono što je omogućuje, teleprisutnost izgrađena (pretežno) jezikom.

Sva navedena saznanja, ne samo o cyber-komunikaciji već i o generalnoj prirodi ljudske komunikacije, vode prema zaključku da znanstvenici koji zastupaju stav da pojedinci mogu biti obestjelovljeni na mreži ipak nisu u pravu. Kao što primjećuju Young i Whitty (2010), autori poput Clarka, Strattona i Levinea umanjuju relevantnost tijela, dok je ono do čega zapravo dolazi u cyber-prostoru tek pseudo ili polovično obestjelovljenje (Ajana 2005). Internet je shvaćen kao prostor utjelovljenog iskustva koji ima potencijal da ukloni ograničenja starog 
tijela i zamijeni ga obnovljenim, ,ja”. Drugim riječima, u cyber-prostoru formiraju se i umnažaju novi identiteti, no nikada se ne nadilaze. To se najbolje oslikava na dva načina: ljudi često opisuju izgled i senzacije svoga tijela, a čak i kada to ne čine ekspicitno, tjelesnost se otkriva u njihovu diskursu (npr. rod, dob, klasna pripadnost) i u ikoničnosti neverbalnog aspekta mrežne komunikacije (npr. emojis).

Zaključak koji se nameće ukazuje da se komunikacija u cyber-prostoru odmiče od tijela (u smislu njegove fizičke prisutnosti) jer se prilagođava mediju komunikacije, no ona ne nadilazi tjelesnost, nego pruža drugačiju pa i veću mogućnost manipuliranja njome. Također, zbog nedostatka zajedničkog fizičkog konteksta i neverbalnih migova cyber-komunikacija demonstrira domišljatost i prilagodljivost korisnika novim okolnostima koji u nju vraćaju gestu. Time nam se pružaju uvidi u evoluciju ljudske komunikacije iz pragmatičke perspektive, kao i uvidi u potencijalnu evolucijsku povezanost različitih semioloških sustava i prirodnog jezika.

Kao što ističe Schandorf (2014: 321), u komunikaciji licem u lice, i u fizički neposrednim kontekstima, jezik se oslanja na neverbalne parajezične migove čije funkcije nisu nužno izgubljene u posredovanoj interakciji. Štoviše, većina je parajezičnih funkcija zadržana u posredovanoj interakciji, što se potvrđuje i na primjeru cyber-komunikacije. Promjena do koje ovdje dolazi nije nestanak geste ili intonacije iz komunikacije, već njihovo prebacivanje iz medija zvuka i pokreta u medij pisma i slike ${ }^{64}$. Drugim riječima, prebacuju se u medij teksta koji je trajniji i statičan, te u kojem postaje sve očitija važnost, povezanost i međuovisnost parajezika i jezično zasnovane komunikacije. Time gesta dolazi u prvi plan: ističe se njezina uloga u komunikacijskom sustavu pri koordiniranju diskursa i uočava se evolucijski potencijal geste za sustav diskursnih oznaka.

Ako gestu definiramo dovoljno široko i shvatimo je kao jedan aspekt jezika (a ne zaseban govor tijela), ili ako neke rubne pojavnosti jezika (poput fonetskog simbolizma) percipiramo kao vokalne geste (npr. njam, auuč, uff, hej!), nametnut će nam se pitanje odnosa jezika i parajezika na sinkronijskoj, posebice dijakronijskoj osi. U novim medijima (s obzirom na to da se vokalnost komunikacije gubi, a tekstualnost povećava) ta povezanost jezičnog i parajezičnog sustava postaje izraženijom. Lako ju je primijetiti na fenomenu posredovane geste, koje su nama ovdje relevantne jer im se funkcije podudaraju s brojnim funkcijama diskursnih oznaka.

\footnotetext{
${ }^{64}$ Do spomenute promjene dolazi zbog prilagodbe mediju interneta koji se pretežno oslanja na tekst.
} 
Geste u cyber-komunikaciji mogu se pojaviti u nekoliko osnovnih oblika (po uzoru na Schandorf 2014): ${ }^{65}$

1. Ritmička gesta (šutnja) - pokret je koji eksplicitno naznačuje, naglašava ili se referira na strukturne aspekte diskursa (njegovu sintaktičku i semantičku organizaciju) i određuje njegov ritam. U kontekstu računalno posredovane komunikacije vrijeme odgovora može se smatrati gestualnim, kao i dužina odgovora te korištenje pauzi. Jedan od boljih primjera ove geste bilo bi slanje iscjepkanih poruka i trotočja s ciljem stvaranja osjećaja napetosti i iščekivanja ili radi upravljanja redom u govorenju. Iz perspektive proučavanja diskursnih oznaka, ovo bi bio primjer korištenja šutnje kao ograde, popunjivača i/ili interaktiva.

2. Fatička gesta - predstavlja fatički aspekt komunikacije s primarnom svrhom održavanja emotivnog i socijalnog kontakta. Obično se manifestira popunjivačima i interaktivima kao podvrstama diskursnih oznaka.

3. Ilokucijska gesta - zapravo predstavlja modifikatore jer modificira ilokucijsku snagu iskaza te obično stoji ispred govornog čina (primjerice usklici).

4. Deiktična gesta - gesta koja ukazuje na hijerarhijske i spaciotemporalne odnose. Služi za kontekstualizaciju, stoga od cyber-fenomena u njih ubrajamo tzv. hashtags (\#) koji funkcioniraju kao ključne riječi, adresivnost (iskazana simbolom @ prije korisnikova imena) i hiperlinkove. Iz perspektive diskursnih oznaka, ove bismo geste mogli ubrojiti u potskupinu konektora.

5. Ekspresivna gesta - gesta je kojom se iskazuje osjećaj ili stav govornika. Manifestira se stilom pisanja (npr. velika tiskana slova kao povišen ton glasa) i upotrebom interpunkcijskih znakova (npr. puno uskličnika i upitnika zaredom, upotrebom asteriska za iskazivanje ironije).

6. Slikovna gesta - gesta je u vidu ikone. Ovdje spadaju svi emotikoni i emođiji, a funkcije im se podudaraju sa svim četirima podskupinama diskursnih oznaka.

7. Amblemska gesta - predstavlja ambleme, tj. formalne, kulturno-specifične neverbalne oblike (najčešće oblike ruku) koji prate jezik i mogu se u njega prevesti. Tu se ubraja palac gore (npr. bravo!), palac dolje (npr. loše), srednji prst, kažiprst preko usta (npr. psssst!!! ili šuti!). Stoga od cyber-specifičnih gesti pod amblemske ubrajamo neke

\footnotetext{
${ }^{65}$ Navedene se kategorije gesta često preklapaju jer su kontekstualno ovisne.
} 
emotikone i emođije, akronime i ikoničke heštegove (npr. \#FAIL). Ovaj bi se tip posredovane geste mogao svrstati pod skupinu interaktiva i modifikatora.

Govoreći o jezičnoj evoluciji, neki autori poput McNeilla (2005) smatraju da su gesta i jezik potekli iz istog izvora: izvora predlingvističkih, dinamičkih kognitivnih procesa koji su poslužili kao osnova konceptualizacije i komunikacije. Nadalje, njezin značaj vidljiv je u našoj tjelesnosti koja je (kao što smo vidjeli) nerazdvojivo vezana uz naš jezik i spoznaju. Proučavanja odnosa geste i jezika imaju potencijal naučiti nas mnogo o pragmatici prirodnog jezika i njegovim sociosemiološkim osnovama. Na posljetku, složili bismo se s Whartonom (2009: 148) koji je pretpostavio teorijsku povezanost prozodije i geste s graničnim jezičnim izrazima (poput usklika) i onim punopravnim (poput diskursnih veznika i čestica, tj. diskursnih oznaka), jer smo taj fenomen i sami zapazili u cyber-komunikaciji. Pretpostavljamo da se ta povezanost najbolje pokazuje na evolucijskoj osi, procesom gramatikalizacije diskursnih funkcija o kojoj će više riječi biti u dijelovima teksta koji slijede.

Čitav podnaslov možemo zaključiti tvrdnjom da su imitativi i šutnja međusobno povezani s diskursnim oznakama putem ikoničnosti jezika koja se jasno oslikava u gesti (u ovom slučaju $\mathrm{u}$ internetom posredovanoj gesti). Tako nešto nastojat će se ilustrirati razvojem DO-a i problematikom odnosa DO-a i šutnje, što dolazi u fokus u podnaslovima koji slijede. 


\section{2. Diskursne oznake kroz prizmu povijesti}

Većina dosadašnjih lingvističkih istraživanja diskursnim je oznakama pristupala iz sinkronijske perspektive. ${ }^{66}$ Ipak, iz literature se može izdvojiti nekolicina autora čiji je doprinos dijakronijskom izučavanju diskursnih oznaka neosporiv. Među njih se u prvom redu ubraja Elizabeth Traugott, tj. autoričin rad na temu gramatikalizacije pragmatičkih funkcija (1995), te pragmatička teorija jezične promjene koju je razradila u suautorstvu s Richardom Dasherom (2005). ${ }^{67}$ Spomenuti se model još uvijek smatra paradigmatskim za područje historijske pragmatike. Ukratko, teorija na semantičku promjenu gleda kao na posljedicu pragmatičkih upotreba, a temelji se na Levinsonovoj teoriji generalizirane konverzacijske implikature. Prema IITSC modelu, promjene u značenju i funkciji jezičnih jedinica ogledaju se u sljedećoj klinalnoj varijabilnosti:

a) istinitosna uvjetovanost > istinitosna neuvjetovanost

b) sadržajno značenje $>$ sadržajno i proceduralno značenje $>$ proceduralno značenje

c) doseg unutar iskaza $>$ doseg onkraj iskaza $>$ doseg preko (odsječka) diskursa

d) nesubjektivno značenje > subjektivirano značenje > intersubjektivno značenje.

To se izvrsno oslikava procesom nastanka i razvoja diskursnih oznaka, što će ovdje biti oprimjereno diskursnom oznakom uglavnom. Prateći IITSC model, gore navedene promjene odvile su se na sljedeći način:

a) Porijeklo DO-a uglavnom dolazi od priloga sa značenjem najčešće, u većini slučajeva, uobičajeno. Primjer upotrebe punoznačnog priloga uglavnom, prije početka procesa semantičkog bijeljenja, preuzet s hrWac-a ${ }^{68}$ bio bi sljedeći:

I Nutricionisti se uglavnomslažu da nam je dnevno potrebno od 90 do $100 \mathrm{mg}$ vitamina C.

U navedenom je primjeru još uvijek riječ o prilogu koji se može (kao i čitav iskaz) testirati na istinost, tj. njegova će prisutnost ili odsutnost promijeniti značenje (pa time

\footnotetext{
66 Vidi poglavlje 4.

${ }^{67}$ Invited Inference Theory of Semantic Change (IITSC) - teorija/model za izučavanje jezičnih promjena diskursne razine.

${ }^{68}$ Dostupno na URL: https://www.clarin.si/noske/all.cgi/first?iquery=uglavnom\&corpname=hrwac\&corpussearch-form=true $(30.6 .2020$.
} 
i istinitost) iskaza. To najlakše možemo provjeriti ako prilog uglavnom uklonimo iz iskaza ili ga zamiijenimo nekim drugim prilogom. Primjerice:

„Nutricionisti se (rijetko) slažu da nam je dnevno potrebno od 90 do 100 mg vitamina C.”

U slučaju diskursne oznake, kao u sljedećem primjeru ${ }^{69}$, njezino uklanjanje iz iskaza neće promijeniti značenje ni istinitosnu vrijednost iskaza:

I Uglavnom, zahvaljujici i konzultacijama sa svojim prijateljicama iz Croatia Airlinesa (puno hvala - Vera $i$ Kati:) danas sam na aerodromu najprije nasla super povoljan let za Meksiko (skoro 3 put jeftiniji od onih koje su mi do sada nudili...), i to preko kolumbijske agencije Avianca.

b) Zajedno s gubljenjem osjetljivosti na istinitosne uvijete, izrazi (riječi ili fraze) iz kojih nastaju diskursne oznake postupno gube i vlastito sadržajno (referencijalno, semantičko) značenje. Ono što se umjesto njega javlja jest tzv. proceduralno, odnosno pragmatičko značenje, no u međufazi oba tipa značenja mogu supostojati. To se ponovno može ilustrirati prethodnim primjerima. U slučaju nutricionista i njihova slaganja u mišljenju prilog uglavnom prenosi semantičko značenje količine, tj. učestalosti radnje slaganja aktera u pitanju. $\mathrm{S}$ druge strane, uglavnom u primjeru prepričane zgode o kupnji avionske karte ne posjeduje značenje učestalosti obavljanja neke radnje, već prelazi u tzv. proceduralno značenje ${ }^{70}$ koje služi za otvaranje reda u govorenju, započinjanje, nastavljanje ili strukturiranje narativa te svraćanje slušateljeve pažnje na (nama) relevantne informacije.

c) Sljedeća je promjena do koje dolazi u procesu nastanka diskursnih oznaka promjena dosega njihova značenja. Drugim riječima, njihov se doseg obično širi. Tako u prvome primjeru uglavnom ima doseg isključivo unutar tog iskaza i sukladno tome odnosi se na činjenicu da se nutricionisti uglavnom slažu oko te specifične tvrdnje (tj. oko unosa preporučene dnevne količine vitamina C). U primjeru s avionskom kartom uglavnom koje se pojavljuje u inicijalnom položaju seže onkraj iskaza i odnosi se na čitav odsječak diskursa.

\footnotetext{
${ }^{69}$ Primjer je preuzet iz korpusa hrWac, dostupno na URL: https://www.clarin.si/noske/all.cgi/sortx?q=q\%5Blc\%3D \%22uglavnom \%22+\%7C+lemma_lc\%3D\%22uglavno $\mathrm{m} \% 22 \% 5 \mathrm{D \& q}=\mathrm{p}-$

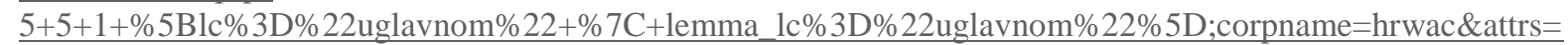
word $\% 2 \mathrm{Ctag} \& c t x a t t r s=$ word \&structs $=\mathrm{p} \% 2 \mathrm{Cg} \& \mathrm{refs}=\% 3$ Dtext.urldomain \&pagesize $=150 \&$ iquery $=$ uglavnom;ske $\mathrm{y}=\mathrm{lc} ;$ sicase $=\mathrm{i}(30.6 .2020$.)

${ }^{70}$ Više o tipovima značenja u podnaslovu koji slijedi.
} 
d) Naposljetku, iz potpuno nesubjektivnog značenja prilog uglavnom postepeno podliježe procesu subjektifikacije (kao i intersubjektifikacije) značenja. Ukratko, dolazi do idiomatizacije konvencionalnih izraza, ponekad zbog naglaska na govorniku (subjektivno značenje), a ponekad zbog isticanja važnosti sugovornika (intersubjektivno značenje). Neki autori ovu pojavu smatraju pratiteljem procesa gramatikalizacije, neki podvrstom semantičke reanalize, dok je neki poistovjećuju s pragmatikalizacijom.

\begin{tabular}{|c|c|}
\hline NoSketch文 Engine & - Q $\equiv$ hrWac (Croatian Web). \\
\hline \multicolumn{2}{|c|}{$\begin{array}{l}\text { Sketch Engine homepage } \\
\text { Home }\end{array}$} \\
\hline Search & Query uglavnom 285,971 (204.59 per million) (i) \\
\hline Word list & Page 1 of 1,907 Go Next I Last \\
\hline Corpus info & ) \& Tekstovi koji se odnose na srednjovjekovnu književnost uglavnom $/$ Rgp su pisani glagoljicom i staroslavenskim jezikom, koji u \\
\hline My jobs & potrebu za aktivnošću i neka je po noći uvijek u kući (mačke uglavnom $/ \mathbb{R g g}$ love noću). Možete i postaviti zvonce na njenu ogrlicu kako \\
\hline \multirow{2}{*}{ User guide $\longleftarrow$} & library.foi.hr. G Zavičajna zbirka ima 120 knjiga. To su uglavnom $/ \mathbb{R g g p}$ djela Ksavera Šandora Gjalskog različitih izdanja od \\
\hline & liječenja. $\subseteq$ Promicanje zdravlja na radnome mjestu uglavnom $/ \mathbb{R g g p}$ je usredotočeno na promicanje zdravlja radnika kroz \\
\hline & žirija zabilježio za svaku izvedbu na koncertu. Mi uglavnom /Rgp možemo biti zadovoljni i sretni jer smo dobili same pohvale \\
\hline Save $\quad$ & teži $\mathcal{G}$ U stabilnoj plinskoj instalaciji nalazi se pod tlakom uglavnom $\mathbb{R}_{\text {Rgp }}$ zemni plin koji je lakši od zraka i prilikom \\
\hline Make subcorpus & pripadnika porodica pasa i mačaka. U prirodi se hrane uglavnom /Rgp gazelama, a ovaj zanimljiv par u Osijeku dobiva svaki drugi \\
\hline View options & dobiva svaki drugi dan pojedinačno po $2 \mathrm{~kg}$ svježeg mesa, uglavnom /Rgp govedine, te jednom u dva tjedna vitamine i minerale. $₫ 23$. \\
\hline KWIC & godine 1981 / 82 u novo naselje Dugave doseljava se oko 4 500, uglavnom /Rgp radničkih obitelji (oko 18000 stanovnika). S \\
\hline Sentence & se provode s vremena na vrijeme i na seminarima. Uključuju uglavnom $/ \mathbb{R g p p}$ posturalnu dijagnostiku, korektivne vježbe, masažu i \\
\hline Sort & Kamena škropionica ima motiv kriške. Crkveni je namještaj uglavnom $/ \mathbb{R g p}$ iz doba baroka i klasicizma. I Glavni oltar tektonskog tipa \\
\hline Left & zemljisne-zajednice.hr pašnjake, a mještani Supetarske Drage i danas na tom dijelu uglavnom \\
\hline Right & zraka.hr $\quad$ samo kod stečajnih upravitelja koji su se specijalizirali uglavnom /Rgp za smanjenje troškova ili zatvaranje poduzeća. \\
\hline Node & od svjetlosti, što je uzdrmalo svijet... I Nutricionisti se uglavnom/Rgs slažu da nam je dnevno potrebno od 90 do $100 \mathrm{mg}$ vitamina C. \\
\hline References & riječi. Ove božanske riječi svojedobno su se prenosile uglavnom $\mathbb{R}_{\text {Rgp }}$ usmeno jer ih je većina ljudi mogla zapamtiti i shvatiti \\
\hline Shuffle & potrebno za križni put kao i složili tekst koji je slijedio uglavnom /Rgp Sveto pismo, no bilo je tu i dodataka. Tekst su naši \\
\hline Sample & . " - Osho " Ljubav je stanje u kojemu čovjek vidi stvari uglavnom $/$ Rgp onakvima kakve one nisu. " - Nietzsche " Ljubav je \\
\hline Filter & . Točno. Ali to nije dovoljno. Ljubav koja se izražava uglavnom $/ R$ kgp kroz kuhanje, spremanje, zarađivanje, odvođenje na \\
\hline Sub-hits & , i ljubav kako bismo im pomogli da se izvuku od napasti. Uglavnom /Rep ne želimo takvim ljudima pomoći, jer mislimo da nisu \\
\hline 1st hit in doc & tvom životu. Ne možemo dobiti ili postići ono što volimo ako uglavnom /Rgp mislimo i pričamo o tome kako nam to nedostaje. Negativne \\
\hline Frequency & neslužbenih rezultata naših članova u LOGU. Uglavnom $/ \mathbb{R g p}$ jutros su skoro svi bili u skladu s očekivanjima. Od mlađih \\
\hline Node tags & . Međutim, nije nevažno kakvu sol koristite. danas se uglavnom $/ \mathbb{R g p}$ preporuča morska, $i$ to nejodirana. Unos ove namirnice, \\
\hline Node forms & za tom namirnicom. Pravi je apsurd to što se ta količina uglavnom $/$ Rgp dobije jednostavnom konzumacijom namirnica koje već u \\
\hline Doc IDs & i vanbrodskim motorima, njihovim dijelovima i opremom. Uglavnom $/ R_{\mathrm{gp}}$ sa svim proizvodima vezanim za mehaniku u nautici. $\varphi$ Opskrba \\
\hline Text types & preventivne aktivnosti koje su se odvijale u našoj školi uglavnom $/ \mathbb{R g p}$ su se ticale utjecaja i štetnosti alkohola i marihuane.... \\
\hline Collocations & života i statusa svoje gluhe djece, u sredini u kojoj uglavnom $/ \mathbb{R g p}$ nema previše informacija, poticaja, a i razumijevanja za \\
\hline Visualize & rezultati nekolicine članova koji su posjećivali rally-e uglavnom /Rgp sami financirajući odlaske na natjecanja ne spominjući \\
\hline & modula $\subseteq$ Solarni fotonaponski sustavi primjenjuju se uglavnom $/ \mathbb{R g p}$ za napajanje trošila relativno malih snaga. Kako je razvoj \\
\hline \multirow[t]{5}{*}{ Menu position } & od važnosti prvog jutarnjeg obroka doručka, kojeg djeca uglavnom $/$ Rgp konzumiraju u vrtiću, osjetila sam se odgovornom učiniti \\
\hline & bosanske krize slijedili su europska iskustva, uglavnom ${ }_{/ R g p}$ švicarska i belgijska 22. I STVARNOSTI I PREDRASUDE \\
\hline & , razaranja i ljudske patnje. lako su se mirovni aranžmani uglavnom $/ \mathbb{R g p}$ ticali Bosne, treba spomenuti da je hrvatski doprinos bio \\
\hline & u okretanju na sjeverac $\mathrm{i}$ buru. Najviša dnevna temperatura uglavnom $/ \mathbb{R g p}$ od 18 do 23 , na Jadranu i u Zagori od 22 do $26 \mathrm{C}$. I Stanje na \\
\hline & prirodne ravnoteže. $\subseteq$ Razlozi nade koja je u nama $\subseteq$ Ljudi uglavnom /Ron znaju da demonstracije imaju neke veze sa politikom, pa \\
\hline Grafički p & z 9: Prikaz primjera pretraživanja i konkordancije rječi uglavnom iz korpusa \\
\hline
\end{tabular}

Uz Traugott, Richard Waltereit (profesor na Odsjeku za romanistiku Sveučilišta Humboldt u Berlinu) jest kako samostalno, tako u suautorstvima dao vlastiti uvid u evoluciju diskursnih oznaka. Od njegovih relevantnijih radova izdvojili bismo članke The Rise of Discourse Markers in Italian: a specific type od language change (2006), Grammaticalization vs. reanalysis: a semantic-pragmatic account of functional change in grammar (2002), te članak napisan $u$ suautorstvu s Ulrichom Detgesom Turn-taking as a trigger of language change (2011). 
Waltereit (za razliku od Traugott) naglasak stavlja na sugovornika te pretpostavlja da diskursne oznake nastaju u procesu pregovaranja diskursne strukture.

Uz spomnute autore neće biti na odmet dodati još poneki pojedinačni doprinos poput preglednog članka o evoluciji diskursnih oznaka autora Hansen i Rossari (2005) i perspektivu Gabrielle Diewald (2011) koji naglašavaju važnost konteksta i koteksta za semantičkopragmatičku promjenu. Pri tome također ističu potencijal pogrešnih (nenamjeravanih) interpretacija, višeznačnosti i dvosmislenosti kao materijala i inicijatora promjene.

Osnovni je pojam koji se provlači kroz dijakronijska istraživanja diskursnih oznaka pojam gramatikalizacije. Ipak, ovdje nije riječ o gramatikalizaciji u klasičnome smislu kako je definira Lehmann (1995), već gramatikalizacije u nešto širem smislu. Traugott je definira na sljedeći način (1995: 1):

„... grammaticalization is the process whereby lexical material in highly constrained pragmatic and morphosyntactic context becomes grammatical, in other words that lexical material in specifiable syntactic functions comes to participate in the structural texture of the language,..."

Kao što ćemo kasnije vidjeti ${ }^{71}$, i uz ovaj se termin (kao i uz termin diskursnih oznaka) vežu brojne rasprave i neslaganja, no pojam u osnovi označava povijesni proces nastanka diskursnih oznaka. Naposljetku, uz ovu se dijakronijsku problematiku vezuje i tema značenja diskursnih oznaka te procesi pragmatikalizacije i subjektifikacije $\mathrm{e}^{72}$.

Prije prelaska na konkretne probleme vezane za nastanak i razvoj diskursnih oznaka, ovaj kratak uvod zaključili bismo u pozitivnoj noti, naglasivši da se u posljednjih petnaestak godina sve više budi interes za proučavanje dijakronijskih procesa na diskursnoj razini. To je zasigurno

\footnotetext{
${ }^{71}$ Poglavlje 5.3.

${ }^{72}$ Pojam subjektifikacija dolazi od engl. termina subjectification, skovanog po uzoru na termin gramatikalizacija. Iako sam termin ima dodirnih točaka s terminima subjektivacija i subjektivizacija, između navedenog potrebno je činiti razliku. U sklopu dijakronijske lingvistike, subjektifikacija je proces jezične promjene kojom jezični iskaz dobiva značenja što prenose stavove ili perspektivu određenog govornika/subjekta. U sklopu lingvistike, subjektifikacija (ponekad nazivana i subjektivizacijom kod francuskih teoretičara) smatra se pragmatičkosemantičkim procesom promjene značenja, što uzrokuje promjene na leksičkoj i gramatičkoj razini. Za razliku od domene jezikoslovlja, pojam subjektivizacije (ponekad nazivan i subjektivacijom) u području filozofije, sociologije i političkih znanosti shvaćen je u nešto širem smislu. Subjektivizacija se ondje često vezuje uz ime Michela Foucaulta i odnose moći u društvu, a shvaćena je kao proces sastavljanja subjekta koji je objekt za samoga sebe. U takav proces subjektivizacije/subjektivacije spadaju procedure s pomoću kojih subjekt promatra sebe samoga, analizira, interpretira i prepoznaje u domeni mogućeg znanja. Drugim riječima, to je proces činjenja čega subjektivnim (ne isključivo jezika i koncepata, već čitavog socijetalnog iskustva). Detaljnije o procesu subjektifikacije pogledaj u podnasluv 5.3.3.
} 
potaknuto oživljavanjem interesa za proces gramatikalizacije, ali i olakšano je, tj. omogućeno pojavom novih tehnologija. Digitalizacija komunikacijskog procesa i izrade mrežnih korpusa omogućile su pragmatičarima gotovo prvi puta u povijesti izravan pristup autentičnim, sirovim podacima za istraživanja (promjena) jezične upotrebe. Naposljetku, uvela se i mogućnost kvantitativne analize, u čemu su se neki poput autora Koops i Lohmann (2015) već okušali u svojoj studiji A quantitative approach to the grammaticalization of discourse markers: Evidence from sequencing behavior.

\subsubsection{Problem značenja diskursnih oznaka}

U ranim istraživanjima diskursnih oznaka samo postojanje njihova značenja dovođeno je u pitanje. Ipak, s vremenom je uviđeno da bi ispravnije bilo zapitati se kakvo je to značenje, a ne ima li ga.

U pravilu, riječi mogu imati dvije moguće vrste značenja: $:^{73}$

1. semantičko, konceptualno, propozicijsko, reprezentacijsko, denotativno, tj. jezgreno

2. pragmatičko, instruktivno, djelatno, interakcijsko, konotativno, tj. proceduralno.

Ovdje je potrebno imati na umu da navedeni oblici značenja u spomenutim dvjema kategorijama nisu sinonimni ili nisu u potpunosti sinonimni te da nisu zamijenjivi. No ovakvom podjelom pokriveni su svi aspekti značenja koji ovise o različitim jezikoslovnim perspektivama i/ili razinama.

Jasno je da diskursne oznake posjeduju obilježja druge skupine značenja, no zbog njihova porijekla iz punoznačnih leksičkih kategorija i procesa semantičkog izbjeljivanja pri njihovu nastanku često se propitivalo koliko semantičkog značenja u ovoj skupini izraza preostaje. Iz tog su razloga diskursne oznake dugo vremena bile na granici između funktiva i punoznačnica. Također, različiti su autori iz vlastitih perspektiva drugačije pristupili problematici značenja diskursnih oznaka.

Deborah Schiffrin promatrala je u kojem stupnju diskursne oznake doprinose cjelokupnom značenju nekog diskursa te u kojoj mjeri one odražavaju već dostupno semantičko značenje. Za razliku od Schiffrin, Bruce Fraser proučavao je značenje DO-a u odnosu na značenje rečenice

\footnotetext{
${ }^{73}$ Po uzoru na Dolić (2016: 39).
} 
i u odnosu na značenje iskaza. Pri tome autor razlikuje sadržajno (engl. content meaning), tj. referencijalno značenje od pragmatičkog značenja koje se odnosi na govornikovu namjeru. ${ }^{74}$ Nakon diskursnog i pragmatičkog pristupa, autori poput Maschlera odabrali su perspektivu funkcionalne interakcijske lingvistike ${ }^{75}$ za izučavanje problematike značenja diskursnih oznaka. U sklopu takvih pristupa pretpostavlja se međuovisnost semantičkog i pragmatičkog značenja, što se argumentira praćenjem razvoja diskursnih oznaka ${ }^{76}$ i njihovim metajezičnim ${ }^{77}$ karakterom. Tako shvaćene, diskursne se oznake percipiraju kao sustav koji tvori dio većeg ikoničkog sustava gramatičkih, prozodijskih i kinezičkih obilježja ${ }^{78}$ (Kendon 1995). Smatra se da spomenuta obilježja pomažu sudionicima komunikacije pri razlikovanju istaknutijih promjena (semantičkih) okvira od onih suptilnijih. Naposljetku, teoretičari relevantnosti poput Diane Blakemore uvode razliku između konceptualnog i proceduralnog značenja koje se u suštini temelji na razlikovanju procesa (semantičkog) dekodiranja od (pragmatičkog) procesa zaključivanja (pri čemu su oba procesa shvaćena u nešto širem smislu ${ }^{79}$ ).

Za potrebe ovog rada, posebice za potrebe dijakronijske analize, te zbog šireg konteksta rada kao sociopragmatičkog sa semiološkim aspektima, kao i zbog prirode korpusa podvrgnutog analizi (jezik i komunikacija u dijaloškoj formi), odlučili smo se za razlikovanje sljedećih dvaju tipova značenja: jezgreno i proceduralno značenje.

\subsubsection{Jezgreno značenje}

Jezgreno značenje predstavlja središnji semantički sadržaj određenog leksema i pretpostavlja se da ga diskursne oznake zadržavaju i nakon procesa semantičkog bijeljenja (Schiffrin 1987; Fraser 1990; Redeker 1991). Kod različitih se autora na jezgreno značenje ponekad referira i kao na osnovno, apstraktno, invarijantno i inherentno semantičko značenje. Njemu se suprostavlja periferno značenje koje je odmaknuto od prototipne jezgre i koje nestaje $\mathrm{u}$ procesu gramatikalizacije, tj. u procesu nastanka diskursnih oznaka. Gubljenjem većine konceptualnog, tj. semantičkog značenja, diskursne oznake prvenstvo pružaju pragmatičkom

\footnotetext{
${ }^{74}$ Fraser ovime podrazumijeva jasno razgraničenje između semantike i pragmatike.

${ }^{75}$ Nastavljajući se na nasljeđe M.A.K. Hallidaya i Ervinga Goffmana.

76 Točnije procesom semantičkog izbjeljivanja kao jednim od osnovnih odlika procesa gramatikalizacije.

${ }^{77}$ Metajezični karakter diskursnih oznaka najbolje se odražva kada DO-i obnašaju poetsku, fatičku ili metajezičnu funkciju (za razliku od referencijalne, eskpresivne i konativne funkcije).

${ }_{78}$ Sto nas vraća na teoriju gestovnog porijekla jezika, kao i na relevatnost utjelovljene spoznaje za jezični razvoj.

${ }^{79}$ Sematici se pripisuje logičko povezivanje pojmova, dok se domeni pragmatike pripisuje interpretacija i kodiranje namjere u specifičnom komunikacijskom kontekstu.
} 
značenju, tj. onome što Blakemore naziva proceduralnim značenjem (2002). Iako se pojam jezgrenog značenja $\mathrm{u}$ potpunosti ne podudara s pojmom semantičkog i konceptualnog značenja $^{80}$, relevantan je za proučavanje evolucije diskursnih oznaka jer ukazuje na njihove jezične izvore (etimologija) te njihove sadašnje (i potencijalne) funkcije na diskursnoj razini. Objašnjeno prethodnim primjerom, uglavnom kao prilog predstavlja učestalost neke radnje, točnije predstavlja glavninu, većinsko ponašanje ili stanje. Iako se procesom semantičkog bijeljenja spomenut semantički sadržaj gubi, jezgra ostaje, što je vidljivo u upotrebi i funkciji diskursne oznake uglavnom. Ona često dolazi na inicijalnom položaju u iskazu s ciljem njegova strukturiranja, otvaranja reda i sažimanja čitavog narativa, čime se ujedno otvara i njegova minimalna struktura. Upravo u tom sažetku na početku iskaza ogleda se jezgreno značenje nakadašnjeg priloga i današnje diskursne oznake. Spomenuto značenje okvirno možemo prevesti u frazeme poput sve u svemu, suma sumarum, u globalu i time vidjeti da je jezgra značenja ipak očuvana, no u ovom slučaju više nije primjenjiva na jezične, već na narativne i diskursne (dubinske) strukture.

\subsubsection{Proceduralno značenje}

Pojam proceduralnog značenja preuzet je iz teorije Diane Blakemore, a oslanja se na teoriju relevantnosti i klasike pragmatičke misli poput H. P. Gricea. Ukratko, proceduralno bi značenje predstavljalo informaciju zapisanu u jezičnim konstrukcijama koja nam govori kako upotrijebiti konceptualne reprezentacije u fazi zaključivanja. Takvo je značenje stoga metakomunikativno, metapragmatično, metadiskurzivno, instrukcijsko i primarna je vrsta značenja ove kategorije. Nasuprot proceduralnom značenju nalazi se konceptualno značenje koje podliježe uvjetima istinitosti, dok tim istim uvjetima ne podliježu jedinice isključivo proceduralnog značenja. Drugim riječima, prisutstvo (ili odsutstvo) diskursne oznake neće promijeniti značenje ni istinitost određenog iskaza, no utjecat će na njegovu interpretaciju i proces sugovornikova zaključivanja o smislu iskaza.

\footnotetext{
${ }^{80}$ Pojam jezgrenog značenja uži je od pojma semantičkog ili konceptualnog značenja.
} 


\section{3. Jezične promjene na diskursnoj razini}

Nastavljajući se na prethodnu problematiku nastanka i evolucije diskursnih oznaka, na njihovu ćemo primjeru nastojati objasniti i definirati neke od najpoznatijih procesa jezičnih promjena koje se odvijaju na razini diskursa. Najviše će pažnje biti posvećeno procesu gramatikalizacije i pragmatikalizacije te vezanom procesu (inter)subjektifikacije.

\subsubsection{Gramatikalizacija vs. pragmatikalizacija}

Očekivano je da će istraživači zbog različitih teorijskih modela i metoda imati različite poglede na proces nastanka i evolucije diskursnih oznaka. Ipak, jedan od sporova ovdje dominira i kreće se upravo oko pojmova i termina gramatikalizacija i pragmatikalizacija. Oba su predložena za naziv istovjetnog procesa jezične promjene na diskursnoj razini, no konsezus se unatoč brojnim raspravama nije postigao. Međutim, Degand i Evers-Vermeul (2015: 60) navode autore koji u svojim radovima nastoje uvesti distinkciju između gramatikalizacije i pragmatikalizacije. Pri tome navode autore poput Dostie, Brinton, Diewald, Ocampo, Heine i mnoge druge koji su time makar eksplicirali problem. Također, ono što iz toga postaje jasnim jest da se svi različiti pogledi u svojoj osnovi temelje na različitim konceptualizacijama gramatike.

Pobornici gramatikalizacije (kao procesa evolucije DO-a) u središte svoje argumentacije stavljaju obilježje dekategorizacije izvorne jezične jedinice, određen stupanj fonološke redukcije izvorne jedinice, subjektifikaciju i pojačanu proceduralnost značenja. ${ }^{81}$ Jedna od standardnih definicija gramatikalizacije u ovom kontekstu ona je autora Hopper i Traugott (2003: 18) i govori nam sljedeće:

„Grammaticalization is the change whereby lexical items and constructions come in certain linguistic contexts to serve grammatical functions, and once grammaticalized, continue to develop new grammatical functions."

Nasuprot njima nalaze se pobornici termina pragmatikalizacija kao oznake za proces nastanka DO-a. Ovi se autori (poput Waltereit, Eckardt i Hansen) odlučuju na spomenuti naziv jer se rukovode Lehmannovim parametrima gramatikalizacije, koji u slučaju razvoja diskursnih

\footnotetext{
${ }^{81}$ U ovu skupinu autora mogu se ubrojiti Brinton, Traugott i Diewald.
} 
oznaka ne bivaju u potpunosti zadovoljenima. Ovdje nam je stoga ponuđena nešto drugačija definicija procesa nastanka diskursnih oznaka, što je autorica Frank-Job (2006: 397) sročila na sljedeći način:

„Pragmaticalization is the process by which a sytagma or a word form, in a given context, changes its propositional meaning in favour of an essentially metacommunicative, discourse interactional meaning."

Sami smo se odlučili za termin gramatikalizacija diskursnih funkcija, što bi za nas bilo bliskoznačno s pojmom pragmatikalizacije. Time bismo na proces pragmatikalizacije gledali kao na podvrstu šireg procesa gramatikalizacije, po uzoru na Diewald (2011). Spomenuti se odabir temelji na proširenom viđenju gramatike kao transfrastičke, tj. diskursne gramatike.

\subsubsection{Obilježja procesa gramatikalizacije diskursnih funkcija}

U sklopu procesa gramatikalizacije dolazi do nekoliko različitih promjena, prvenstveno na razini semantike i sintakse.

Semantički su procesi promjene do kojih dolazi sljedeći:

a) Referencijalno (sadržajno/konceptualno) značenje postepeno prelazi u proceduralno (pragmatičko) značenje. To se odvija procesom semantičkog izbjeljivanja, tj. procesom desemantizacije.

b) Bez obzira na desemantizaciju jezgreno značenje gramatikalizirane jedinice opstaje.

c) Dolazi do subjektifikacije značenja (svojevrsne idiomatizacije).

Uz promjene u značenju, dolazi i do sintaktičkih promjena koje se nužno odvijaju tijekom gramatikalizacije:

a) Povećava se doseg jezične jedinice te iskaz koji je nekoć sezao isključivo unutar određene rečenice sada seže onkraj nje, pa čak i preko čitavog diskursa.

b) Dolazi do dekategorizacije, tj. riječi prestaju biti dijelom sintaktičkih kategorija kojima su pripadali njihovi izvornici.

c) Gramatikalizirane riječi postaju sintaktički opcionalne, a njihovo umetanje ili izostavljanje ne narušava gramatikalnost rečenice.

Uz spomenute semantičke i sintaktičke promjene svakako treba navesti i promjene na fonološkoj razini, gdje često dolazi do fonološkog kraćenja. Zanimljivo je da se to manifestira 
i u pisanom, kolokvijalnom cyber-diskursu koji obiluje kraticama, a ono što se često krati ima potencijal da postane ili već jest diskursnom oznakom (npr. msm $<$ mislim, fkt $<$ fakat, bzvz $<$ bezveze).

Zbog uočenih i navedenih promjena cjelokupan proces nastanka i razvoja diskursnih oznaka možemo analizirati, oprimjeriti i postaviti na gramatikalizacijski kontinuum. U nekoliko ćemo sljedećih primjera to nastojati prikazati.

\begin{tabular}{|c|c|c|c|c|c|}
\hline \multicolumn{2}{|c|}{ fonološka razina } & \multicolumn{2}{|c|}{ semantičko-pragmatička razina } & \multicolumn{2}{|c|}{ sintaktička razina } \\
\hline $\begin{array}{l}\text { skraćeni } \\
\text { oblik }\end{array}$ & $\begin{array}{c}\text { neskraćeni } \\
\text { oblik }\end{array}$ & $\begin{array}{l}\text { jezgreno } \\
\text { značenje }\end{array}$ & $\begin{array}{l}\text { proceduralno } \\
\text { značenje }\end{array}$ & $\begin{array}{c}\text { sintaktička } \\
\text { kategorija } \\
\text { izvorika }\end{array}$ & $\begin{array}{c}\text { položaj i } \\
\text { učestalost u } \\
\text { iskazu/diskursu }\end{array}$ \\
\hline$f k t$ & fakat & zaista, uistinu & $\begin{array}{c}\text { otvaranje/zatvaranje } \\
\text { reda u govorenju, } \\
\text { iskazivanje stava, } \\
\text { slaganje sa } \\
\text { sugovornikom }\end{array}$ & prilog & $\begin{array}{l}\text { najčešće } \\
\text { inicijalnog ili } \\
\text { završnog } \\
\text { položaja u } \\
\text { iskazu }\end{array}$ \\
\hline$b z v z$ & bezveze & $\begin{array}{c}\text { odlika čega } \\
\text { lošeg, } \\
\text { razočaravajućeg, } \\
\text { doasadnog, } \\
\text { nevažnog }\end{array}$ & $\begin{array}{c}\text { zatvaranje } \\
\text { razgovora/iskaza, } \\
\text { komentiranje } \\
\text { sadržaja, } \\
\text { iskazivanje emocija }\end{array}$ & prilog & $\begin{array}{l}\text { najčešće } \\
\text { završnog } \\
\text { položaja u } \\
\text { iskazu }\end{array}$ \\
\hline$m s m$ & mislim & $\begin{array}{c}\text { imati mišljenje, } \\
\text { stav }\end{array}$ & $\begin{array}{c}\text { povezivanje } \\
\text { različitih dijelova } \\
\text { diskursa, referiranje } \\
\text { na nešto prethodno } \\
\text { rečeno }\end{array}$ & glagol & $\begin{array}{l}\text { inicijalni } \\
\text { položaj }\end{array}$ \\
\hline
\end{tabular}

Kontekstualizirani primjeri iz korpusa hrWac koji su navedeni u prethodnoj tablici 4:

i. $\quad$ fakat $<f k t<f k t(\mathrm{DO})$

a) Čovjek fakat mora na sve mislit.. Život nekad zna bit $f k t$ težak.. Užas. ${ }^{82}$

b) Najlakše je odmah napast, tamo di svi napadaju, brže će se srušit... I To ti je Sun Tzu rekao?: D I Ne, fkt , daj chill, moj je komentar da takav stil nema previše veze s muškim rodom.. i to je moje

\footnotetext{
${ }^{82}$ Primjer preuzet iz korpsa hrWac. Dostupno na URL: 
mišljenje, a on neka shvati kak hoće... ${ }^{83}$

U primjeru i.a) imamo slučaj neskraćenog oblika priloga fakat te njegov skraćeni oblik u iskazu koji mu slijedi. U obama slučajevima još nije došlo do procesa gramatikalizacije, dok je u drugome došlo samo do procesa kraćenja. No u primjeru i.b) fkt je uz fonološko kraćenje prošlo kroz proces desemantizacije pri čemu je proceduralno značenje preuzelo osnovnu ulogu. Sama prisutnost izraza $f k t$ u tom primjeru ne utječe na referencijalno značenje cjelokupnog iskaza, tj. na njegovu istinitost, no sugovornika usmjerava prema željenoj interpretaciji iskaza. Opseg utjecaja jezične jedinice fkt širi se s dijela iskaza (npr. fakat mislim/ fkt težak) na čitav diskurs ili odsječak diskursa, što je vidljivo i iz migracije samog izraza na periferni položaj u iskazu i njegova odvajanja od ostatka diskursa zarezom. Ako se osvrnemo na prethodnu podjelu diskursnih oznaka iz podnaslova 4.4 , fkt bismo mogli smjestiti u podskupinu interaktiva i/ili modifikatora.

ii. bezveze $<b z v z<b z v z(\mathrm{DO})$

a) $₫$ Što se tiče tvoje temperamentnosti i prostačkog načina izražavanja-možda to izgleda zabavno i simpatično u živo al ovak pišući na internetu zvučiš ko oni nabrijani tipovi koji nam bezveze upadaju u rasprave i vrijeđaju nas. ${ }^{84}$

b) Međutim, on je rekao da histeriziram bzvz i uopće nije htio pričat sa mnom o tom.. a trebao mi je tad. ${ }^{85}$

c) I Da, znam da je danas obilježen i pad Vukovara, ali jednostavno ne želim pisati o tome jer mi je pre licemjerno kako na današnji dan svi spominju Vukovar na sve moguće načine: Na fejsu sve vrvi od filmića i statusa na tu temu, na blogeru se pišu postovi... a drugih dana u godini se nitko ne sjeti... bzvz ...86

U primjeru ii.a) i ii.b) prikazani su prilozi sa svojim punim semantičkim značenjem, no u primjeru ii.c) vidljivo je da više nije riječ o prilogu, već o diskursnoj oznaci u funkciji završnog

\footnotetext{
${ }^{83}$ Primjer preuzet iz korpusa hrWac. Dostupno na URL: https://www.clarin.si/noske/all.cgi/view?q=q\%5Blc\%3D $\% 22 \mathrm{fkt} \% 22+\% 7 \mathrm{C}+$ lemma_lc $\% 3 \mathrm{D} \% 22 \mathrm{fkt} \% 22 \% 5 \mathrm{D} \& \mathrm{q}=$ sword $\% 2 \mathrm{Fi}+1 \% 3 \mathrm{E} 0 \% 7 \mathrm{E} 3 \% 3 \mathrm{E} 0 ;$ corpname=hrwac; viewmode=kwic;attrs=word \&ctxattrs=word $\&$ structs=p $\% 2 \mathrm{Cg}$ \&refs $=\% 3$ Dtext.urldomain \&pagesize $=150$ \&iquery $=$ fkt; fromp $=1$ (7. 7. 2020.)

${ }^{84}$ Primjer preuzet s hrWac-a. URL: https://www.clarin.si/noske/all.cgi/first?iquery=bezveze\&corpname=hrwac\&corpus-search-form=true 7.7. 2020.)

${ }^{85}$ Primjer preuzet s hrWac-a. URL: https://www.clarin.si/noske/all.cgi/first?iquery=bzvz\&corpname=hrwac\&corpus-search-form=true (7. 7. 2020.)

${ }^{86}$ Primjer preuzet s hrWac-a. URL: https://www.clarin.si/noske/all.cgi/first?iquery=bzvz\&corpname=hrwac\&corpus-search-form=true (7. 7. 2020.)
} 
komentara koji se i dalje zasniva na jezgrenom značenju priloga iz kojeg je nastao, no ovdje prenosi stav govornika o sadržaju proteklog diskursa. Prema prethodnoj podjeli u odnosu na funkcije diskursnih oznaka, bzvz (u navedenom kontekstu) možemo svrstati u podskupinu interaktiva.

iii. $\quad$ mislim $<$ mislim (DO) $<$ msm (DO)

a) I Rankus naš jedini predstavnik na nedavno održanom 3. Svera Bike Fightu u Puli nam je napravio mali report. Po fotkama mislim da bi svakako trebali svi do Pule. ${ }^{87}$

b) To isto nije uvreda upućena nekom forumašu. $\llbracket$ Mislim, bzvz mi je tu smišljati primjere. Zato opet kažem. Ovisi o kontekstu. ${ }^{88}$

c) $\quad$ eY.. ljudiCHi.. kak ste?? Ja prfekt Msm .. nisam još do kraja.. ali uskoro ću biti weee.. ${ }^{89}$

U posljednjem primjeru ovog niza prikazan je nastanak diskursne oznake mislim, tj. msm. Pod iii.a) rječ je o glagolu misliti u svojem punom značenju ,imati mišljenje o čemu“ i koji predstavlja izvor za nastanak diskursne oznake. Već u sljedećem primjeru iii.b) mislim se gramatikaliziralo i iz glagola prešlo u konektor na diskursnoj razini, ponekad u popunjivač diskursa ili modifikator već izrečenog dijela diskursa (komentar).

Iz prethodnih primjera nije teško uočiti semantičke aspekte promjene, kao ni fenomen fonološkog kraćenja, no informacije o promjenama na razini sintakse vezane za položaj jezične jedinice dolaze nam iz analize podataka iz mrežnog korpusa. Referentni mrežni korpus poput hrWac-a u ovom slučaju omogućuje izračun frekvencija pojave određene rječi u različitim kontekstima (konkordancijama), što ujedno pojašnjava značenje te rječi i njezin položaj u iskazu. Stoga u grafičkom prikazu 10 (na sljedećoj stranici) možemo vidjeti konkordanciju riječi fkt $\mathrm{u}$ odnosu na njezin desni kontekst, tj. s obzirom na riječ koja se pojavljuje nakon nje.

\footnotetext{
${ }^{87}$ Primjer preuzet iz korpusa hrWac. Dostupno na URL: https://www.clarin.si/noske/all.cgi/first?iquery=mislim\&corpname=hrwac\&corpus-search-form=true (7. 7. 2020.)

${ }^{88}$ Primjer preuzet iz korpusa hrWac. Dostupno na URL: https://www.clarin.si/noske/all.cgi/first?iquery=bzvz\&corpname=hrwac\&corpus-search-form=true (7. 7. 2020.) ${ }^{89}$ Primjer preuzet iz korpusa hrWac. Dostupno na URL: https://www.clarin.si/noske/all.cgi/first?iquery=msm\&corpname=hrwac\&corpus-search-form=true (7. 7. 2020.)
} 


\begin{tabular}{|c|c|}
\hline word & Items: 416 || Total frequency: 912 \\
\hline$\underline{P} \mid \underline{N}$ ne & $58 \square$ \\
\hline$\underline{P} \mid \underline{N}$ je & 38 다 \\
\hline$\underline{P} \mid \underline{N} \mathrm{mi}$ & 37 - \\
\hline$\underline{\underline{P}} \mid \bar{N}$ sam & $30=$ \\
\hline$\underline{P}$ I N & $28=$ \\
\hline PIN. & $22=$ \\
\hline$\underline{P}$ I $\underline{N}$ su & 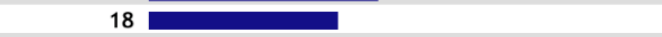 \\
\hline$\underline{P}$ I $\underline{N}$ se & $18=$ \\
\hline$\underline{P}$ I $\underline{N}$ si & 16 - \\
\hline P I N neznam & $13=$ \\
\hline$\underline{P} \mid \underline{N}$ super & $11=$ \\
\hline$\underline{P}$ I N nije & $11=$ \\
\hline$\underline{P} \mid \underline{N}$ nemam & $10 \overline{-}$ \\
\hline$\underline{P} \mid \underline{N}$ puno & $9 \square$ \\
\hline$\underline{P} \mid \underline{N} \ldots$ & $9 \bar{\square}$ \\
\hline$\underline{P} \mid \underline{N}$ u & $8 \longdiv { \square }$ \\
\hline$\underline{\underline{P}} \mid \underline{\underline{N}}$ ste & 8 \\
\hline$\underline{P} \mid \underline{N} .$. & 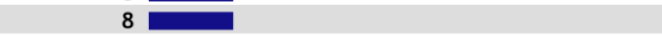 \\
\hline$\underline{P} \mid \underline{N}$ ono & 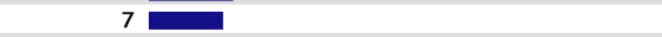 \\
\hline$\underline{P} \mid \underline{N}$ nisam & 7 \\
\hline$\underline{P}$ I jako & 7 \\
\hline$\underline{P}$ I $\underline{N}$ bi & $7 \longdiv { \square }$ \\
\hline$\underline{P}$ I N smo & $6 \square$ \\
\hline P I $\mathrm{N}$ ima & $6 \bar{\square}$ \\
\hline$\underline{P} \mid \underline{N}$ zakon & 5 \\
\hline$\underline{P} \mid \bar{N}$ nema & $5=$ \\
\hline$\underline{P}$ I $\underline{N}$ više & $4 \square$ \\
\hline$\underline{\mathrm{P}}$ I $\mathrm{N}$ treba & $4=$ \\
\hline & $4=$ \\
\hline P I nikad & $4 \overline{-}$ \\
\hline P I N neda & $\Delta$ \\
\hline
\end{tabular}

Dakle, od ukupno 912 pojavnica različnice $f k t$ u 58 slučajeva izraz $f k t$ pojavio se prije $n e, \mathrm{u}$ 38 slučajeva prije je, u 37 slučajeva prije mi, te u 30 slučajeva prije sam. U spomenutim slučajevima izraz $f k t$ našao se u medijalnom položaju, što nije karakteristično za isti izraz u funkciji diskursne oznake, no u slučaju kada nakon pojavnice $f k t$ slijedi zarez (28), točka (22), trotočje (9) i ,krnje" 90 trotočje (8) zaključuje se da je izraz u završnom položaju iskaza. S obzirom na to da je spomenuti finalni (kao i inicijalni) položaj, tj. migriranje izraza na periferiju iskaza jedno od tipičnih obilježja gramatikalizacije diskursnih funkcija, ovakvi podaci pokazuju se iznimno korisnima. Ipak, za razliku od nekih korpusa (npr. Helsinškog dijakronijskog korpusa engleskih tekstova) hrWac nažalost nije vremenski obilježen te nema opciju pretraživanja tzv. trendova upotrebe određene rječi ili izraza unutar dužeg vremenskog perioda. Ono što za sada preostaje jest samostalno provjeriti svaki od primjera u perifernom položaju i vidjeti što bi prema kriterijima procesa gramatikalizacije diskursnih funkcija spadalo $\mathrm{u}$ kategoriju diskursnih oznaka, a što ne bi. S druge strane, hrWac bi bilo poželjno vremenski označiti tako da s vremenom dobijemo mogućnost kvantitativne dijakronijske analize hrvatskog vernakulara.

\footnotetext{
${ }^{90}$ Radi se o omaški u pisanju, pri čemu se ispustila treća točka u trotočju (primjerice .. umjesto ...).
} 


\subsubsection{Problem (inter)subjektifikacije}

Uz proces gramatikalizacije, tj. pragmatikalizacije pri nastanku diskursnih oznaka uobičajen je i proces subjektifikcije. Kao što je prethodno spomenuto, subjektifikacija predstavlja dio semantičkog aspekta jezične promjene i upućuje na razvoj značenja od manje subjektivnog prema više subjektivnom značenju.

Nastala subjektivna značenja upotrebljavaju se da enkodiraju i reguliraju osobne stavove i uvjerenja govornika. Jednom subjektificirana značenja, smatra Traugott (2010), mogu postati i intersubjektivna stavljanjem sugovornika (umjesto govornika) u središte. Autorica navodi da se pri razmatranju subjektifikacije potpomogla podjelom jezičnih funkcija na ideacijsku, tekstualnu i interpersonalnu koju su osmislili Halliday i Hassan, pri čemu su predložili da se posljednje dvije funkcije (tekstualna i interpersonalna) razvijaju iz ideacijske. Ipak, Traugott njihove pojmove zamjenjuje vlastitima, točnije: propozicijskom, tekstualnom i ekspresivnom funkcijom jer smatra da interpersonalna funkcija sadrži kako subjektivna tako i intersubjektivna značenja. Uspoređujući razvoj spomenutih funkcija, tj. klinalnu varijabilnost u procesu subjektifikacije kod Hallidaya i Hassan (i) u odnosu na Traugott (ii), to bi izgledalo na sljedeći način:

i. ideacijska funkcija - tekstualna funkcija - interpersonalna funkcija

ii. propozicijska funkcija - tekstualna funkcija - ekspresivna funkcija.

U slučaju ideacijske, tj. propozicijske funkcije značenje bi ostalo nesubjektivno ili manje subjektivno, tj. bilo bi to semantičko, referencijalno značenje. Tekstualne bi se funkcije u obama modelima također podudarale, a najbolje se mogu oprimjeriti konektorima i popunjivačima kao podvrstama diskursnih oznaka. Naposljetku dolazimo do interpersonalne funkcije koju Traugott izjednačava s ekspresivnom. S autoricom se u tome odabiru ne bismo složili jer smatramo da je subjektivno značenje samo jedan aspekt interpersonalnih odnosa, jednako vrijedno kao i intersubjektivno za razvoj diskursnih oznaka. Tu tvrdnju možemo poduprijeti Jakobsonovom podjelom jezičnih funkcija, pri čemu bi iskazivanje subjektivnog značenja potpalo u domenu eskpresivne funkcije, dok bi iskazivanje intersubjektivnosti bilo uvršteno u domenu konativne funkcije. Ipak, autorici treba priznati da nije u potpunosti zanemarila sugovornika, jer je u problematika uvela pojam intersubjektifikacije koji se 
nadovezuje na samu subjektifikaciju. Ako sve odvedemo korak dalje, u sklopu cyber-konteksta i hiperpersonalnosti kao njegove odlike koja nadilazi interpersonalnost, uvidjet ćemo da na ovaj kontinuum promjene možemo uvesti i fatičku funkciju. Iz tog razloga, predložili bismo nadogradnju modela subjektifikacije autorice Traugott (i) na sljedeći način (ii):

i. ne-/manje subjektivno značenje - subjektivno značenje - intersubjektivno značenje

ii. ne-/manje subjektivno značenje (impersonalno) - subjektivno značenje (personalno/ekspresivno) - intersubjektivno značenje (interpersonalno, konativno) - fatičko (hiperpersonalno) značenje.

Po mišljenju Traugott (2010: 6) ni subjektifikacija kao ni intersubjektifikacija ne sadrže gramatikalizaciju, međutim između gramatikalizacije i subjektifikacije postoji jaka korelacija i nešto slabija između gramatikalizacije i intersubjektifikacije. Subjektifikacija time nije ograničena isključivo na gramatikalizaciju, no češće će se pojaviti u njoj nego u procesu lekiskalizacije ili semantičke promjene u općem smislu.

Osnovne odlike procesa subjektifikacije bile bi sljedeće (Traugott 2010: 8):

- može služiti za iskazivanje stupnjevitosti nekog značenja,

- obično se javlja u prvoj fazi procesa gramatikalizacije (u procesu prijelaza s leksičke na gramatičku jedinicu),

- subjektificirane jedinice obično se pomiču na periferiju iskaza (što se i ne smatra dijelom procesa gramatikalizacije ako se prate Lehmannovi kriteriji).

Traugott naglašava da intersubjektivna značenja neće toliko često biti gramatikalizirana (osim u primjerima uzvika i nekih diskursnih oznaka), no postoje iznimke poput japanskog sustava honorifika koji se gramatikalizirao u pravom smislu te riječi.

Pretpostavlja se da u pozadini ovih semantičkih promjena leže dva unutarnja mehanizma: konceptualna metafora koja se rukovodi principima analogije i metonimija navođena principima reanalize. Nadalje, neki autori poput Hapelmath (Traugott 2010: 17) navode različite čimbenike koji mogu potaknuti proces subjektifikacije poput podsvjesnog procesiranja, rutinizacije i želje za isticanjem (ekstravagancijom). Osim navedenih motiva, pretpostavlja se da su simultana jezična proizvodnja i percepcija, kao i njezine nenamjeravane posljedice okidači za početak subjektifikacije. Time se posljedično nalaže da je za proučavanje ovakvih dijakronijskih procesa potreban model jezične proizvodnje, kao što predlažu Moxey i Sanford (Traugott 2010: 18): 
„Because of the deictic shifts of Speaker and Addressee in the speaking dyad, we need a model of change that accounts for how members of the dyad interact, and above all a production model of how speakers construct arguments about propositions, and [assign] degrees or statements of confidence to those propositions."

Za tako nešto vjerujemo da bi najbolje odgovarao model transfrastičke gramatike, s naglaskom na jezičnom djelovanju, interakciji i jezično-pragmatičkim funkcijama. Trenutni najbolji kandidat za obavljanje tog zadatka čini se model funkcionalne diskursne gramatike autora Hengveld i MacKenzie (2008), o čemu je više rječi bilo u podnaslovu 3.5.

\section{4. Evolucija diskursnih oznaka u cyber-komunikaciji}

Prateći prijašnji tijek misli i prirodu prethodno spominjanih jezičnih razvojnih procesa, ovu bismo raspravu voljeli povesti još jedan korak dalje. Što se sljedeće događa na gramatičkom kontinuumu, prestaje li ovdje razvoj diskursnih oznaka ili im jezik dopušta da završe svoju metamorfozu? Ako je posljednje točno, zašto i kako se to događa i što je (konačan) proizvod?

Naš odgovor na to pitanje bio bi nastanak poštapalica. Mi ne tvrdimo da sve diskursne oznake prolaze kroz ovu fazu razvoja, no one koje to čine, tvore još jednu vrlo problematičnu funkcionalnu kategoriju jezičnih izraza. Ova je kategorija često bivala marginaliziranom i negativno definiranom (kao jezični balast) iz perspektive tradicionalne gramatike, a normativna literatura obilježila ju je kao kategoriju sačinjenu od zalihosnih i nefunkcionalnih jezičnih jedinica. Izuzev toga, poštapalice su često percipirane kao pokazatelji loših retoričkih vještina ili pak znak negativnih estetskih vrijednosti upotrebe jezičnih jedinica.

Čak i u funkcionalnim (komunikacijski orijentiranim) pristupima poštapalicama, njihova kategorizacija ostaje nejasnom, ako se uopće spominje. Povrh svega, termini poštapalica i diskursna oznaka često se upotrebljavaju naizmjenice (kao da je riječ o sinonimima), što u čitavu problematiku donosi dodatnu zbrku. S druge strane neki poštapalice smatraju potkategorijom diskursnih oznaka.

Kao rješenje ovog problema predložili bismo da se poštapalice tretira kao funkcionalnu kategoriju na razini diskursa, koja se razvila iz kategorije diskursnih oznaka prolazeći kroz tri osnovna procesa koji su doveli do dviju velikih promjena: 1. povećanja frekvencije u upotrebi (redundantnost, buka u kanalu) i 2. nasumičnosti položaja u iskazu (funkcija jednog 
popunjivača diskursa ovdje se proširila na sve potencijalne praznine). To rezultira narušavanjem diskurzivne kohezivnosti te narušavanjem učinkovitosti i estetskog aspekta osobnog stila.

Kada bismo usporedili osnovna obilježja diskursnih oznaka i poštapalica, imajući na umu sve rečeno o diskursnim oznakama, možemo zaključiti da među njima postoji znatan stupanj preklapanja. Naime, i DO-e i poštapalice zadovoljavaju neke od osnovnih karakteristika kategorije (desemantizacja, subjektifikacija značenja, sintaktička dekategorizacija, opcionalnost i sintaktička neovisnost), no kod poštapalica ne dolazi do opstanka jezgrenog značenja, već do potpune desemantizacije. Taj proces potpomognut je procesom subjektifikacije koji je odveden u krajnost, što je pak vidljivo u potpuno idiomatiziranim izrazima poput poštapalica. Naposljetku, narušavanjem diskurzivne kohezivnosti poštapalice se odmiču od kategorije diskursnih oznaka jer je upravo to obilježje često smatrano osnovnim obilježjem kategorije DO-a. Zbog navedenih razlika ovdje predlažemo da poštapalicama uvažimo postojanje njihove kategorije, no kategorije koja se razvila iz skupine diskursnih oznaka, ali više ne sačinjava jednu od njezinih potkategorija.

Kao dio računalno posredovane komunikacije poštapalice koje su se razvile iz diskursnih oznaka u vidu kratica uobičajena su pojava. Ponekad dolazi i do prijenosa takvih kratica iz cyber-komunikacije u komunikaciju licem u lice. Najbolji primjeri za to bili bi slučaj LOL (laughing out loud) ili OMG (oh my god) koji su se iznimno brzo proširili inernetom i usmenom predajom, a osim praktičnosti pomažu pri formiranju jezika, kultura i identiteta mladih.

Informacije o kvantiteti upotrebe i raspodjeli, tj. razmještaju poštapalica unutar nekog diskursa, što ih ponajviše razlikuje od kategorije diksursnih oznaka, mogla bi pružiti korpusna lingvistika.

Suprotno slučaju poštapalica, tj. na drugoj strani gramatikalizacijskog spektra/kontinuuma pronalazimo šutnju kao potencijalnu (pod)vrstu kategorije diskursnih oznaka. Ovdje je riječ o obliku dijaloške šutnje, o tzv. ogradama ili pak o obliku ritmičke geste.

U proučavanju kategorije poštapalica i šutnje u nastavku ćemo se voditi teorijom pragmatičko-semantičke promjene autora Traugott i Dasher (2005) s ponekim nadogradnjama i preinakama. 


\subsubsection{Diskursne oznake vs. poštapalice}

U sklopu hrvatskog jezikoslovlja, kao i bliskih mu jezika i njihovih filologija (srpski, bosanski i crnogorski), vrlo se malo pažnje posvetilo poštapalicama. Izuzev kratkih definicija u gramatikama, na prste bi se jedne ruke mogli nabrojati autori koji su se odlučili uhvatiti u koštac s ovom problematikom. Jedna je od njih autorica Zenaida Karavdić koja im se posvetila u znanstvenom radu Poštapalice i uzrečice u bosanskom, crnogorskom, hrvatskom i srpskom jeziku (2010). Karavdić čitatelja uvodi u problematiku navodeći različite definicije termina poštapalica iz hrvatskih i (nekadašnjih) srpsko-hrvatskih rječnika i gramatika (2010: 1-2), čime se izdvajaju i ističu osnovna obilježja kategorije u pitanju. Poštapalice bi prema tome bile okarakterizirane:

- uobičajenošću, rutinizacijom i automatizacijom upotrebe,

- učestalošću upotrebe, ponavljanjem, tj. pojačanom frekvencijom,

- suvišnošću, bespotrebnosti,

- $\quad$ signalizacijom stila (osobnog i/ili grupnog) zbog idiomatizcije izraza.

Normativni priručnici upućuju nas i na pretpostavku da poštapalice isključivo dolaze iz kategorija uzvika ili kategorije čestica, no već nam samo govorno iskustvo nalaže da tomu nije tako. Jer kao što navodi Karavdić (2010: 2):

„Ova terminološka nedosljednost znači da se zapravo u definiranju poštapalice i uzrečice još nisu odredile niti ustalile granice ovih pojmova, naravno, ukoliko granice uopće ima."

Badurina i Matešić (2007: 9) u svome doprinosu temi poštapalica također uočavaju njihovu zapostavljenost u normativističkoj literaturi, no to objašnjavaju kao posljedicu strukturalističkog nasljeđa i njegove usredotočenosti na sustav, a ne na njegovu realizaciju. S ciljem sistematizacije i definiranja kategorije poštapalica autorice su nastojale pružiti kriterije za njihovo prepoznavanje (2007: 16) koji se većinom poklapaju s kriterijima za određivanje diskursnih oznaka:

- $\quad$ semantički (prazne jedinice),

- sintaktički (samostalne i fakultativne jedinice),

- fiziološko-psihološki (uzrokovane, npr. radi dobivanja na vremenu za procesiranje),

- modalno-ekspresivni (izrazi koji prenose stav i emocije), 
- estetski (negativno obilježeni izrazi koji narušavaju stil),

- čestotni (kriterij koji se odnosi na veliku zasićenost diskursa izrazima u pitanju).

Naposljetku, autorice ističu da ni jedan od spomenutih kriterija nije dovoljno jasan, distinktivan ni relevantan, osim kriterija čestotnosti koji je također teško prikazati. To je vidljivo iz sljedećeg citata (Badurina i Matešić 2007: 17):

„Mišljenja smo stoga da je bitno obilježje poštapalice upravo njezino ponavljanje, ne samo unutar rečenice... već i na suprasintaktičkoj/tekstnoj/diskursnoj razini. ..., na očekivano pitanje o broju ponavljanja koja su potrebna da bismo neku jedinicu mogli smatrati poštapalicom neće se moći pružiti jednoznačan odgovor - umjesto kakvih omjera i statistike za to, važan je zapravo samo dojam o zasićenosti govora takvim jedinicama.“

Upravo bismo zbog poteškoća $\mathrm{s}$ ovakvim kriterijima mi pojednostavili prethodnu listu ukazujući na neke od propusta. S autoricama bismo se složili da postoje određena podudaranja između diskursnih oznaka i poštapalica, no ovdje su nam iznimno relevantne i njihove razlike koje prema nama proizlaze iz procesa gramatikalizacije i procesa subjektifikacije. U slučaju poštapalica spomenuti su se dijakronijski procesi „oteli kontroli”, tj. otišli su korak dalje.

U usporedbi bi s kategorijom diskursnih oznaka obilježja poštapalica prema našem mišljenju izgledala na sljedeći način:

\begin{tabular}{|c|c|c|}
\hline & diskursne oznake & poštapalice \\
\hline semantička razina & $\begin{array}{ll}\text { - } & \text { semantički su } \\
\text { izblijedile, ali } \\
\text { zadržavaju jezgreno } \\
\text { značenje } \\
\text { - } \quad \text { subjektivirane su ili } \\
\text { intersubjektivirane }\end{array}$ & $\begin{array}{l}\text { - u potpunosti su } \\
\text { desemantizirane, } \\
\text { nemaju semantičku } \\
\text { jezgru } \\
\text { - } \\
\text { hipersubjektivirane su }\end{array}$ \\
\hline sintaktička razina & 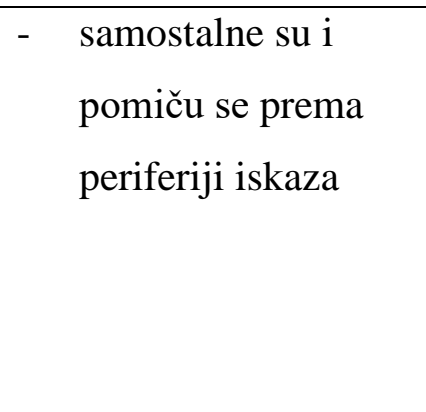 & 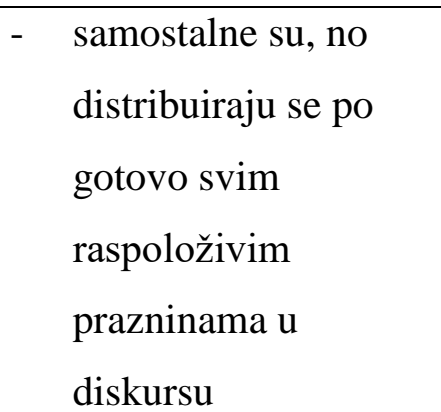 \\
\hline
\end{tabular}




\begin{tabular}{|c|c|c|c|c|}
\hline pragmatička razina & & $\begin{array}{l}\text { upotrebljavaju se } \\
\text { svjesno } \\
\text { služe za dobivanje } \\
\text { vremena za } \\
\text { procesiranje i } \\
\text { povezivanje diskursa } \\
\text { (popunjivači i } \\
\text { konektori) } \\
\text { intencionalno } \\
\text { prenose stav i } \\
\text { emocije (interaktivi i } \\
\text { modifikatori) }\end{array}$ & - & $\begin{array}{l}\text { upotrebljavaju se } \\
\text { automatizirano, } \\
\text { nesvjesno } \\
\text { cjepkaju diskurs } \\
\text { umjesto da ga } \\
\text { povezuju (narušavaju } \\
\text { kohezivnost i } \\
\text { koherentnost) } \\
\text { neintencionalno } \\
\text { prenose informacije o } \\
\text { govorniku (npr. tremu } \\
\text { ili manjak znanja) }\end{array}$ \\
\hline sociosemiološka razina & - & $\begin{array}{l}\text { njihov diverzitet u } \\
\text { upotrebi doprinosi } \\
\text { izgradnji osobnog } \\
\text { stila i poboljšanju } \\
\text { retoričkih vještina }\end{array}$ & - & $\begin{array}{l}\text { simboli su idioma, ali } \\
\text { i grupnih identiteta } \\
\text { predstavljenih } \\
\text { jezikom, kao i } \\
\text { pokazatelji socijalne } \\
\text { stratifikacije }\end{array}$ \\
\hline kvantitativni kriterij & & $\begin{array}{l}\text { diskurs ne ostavlja } \\
\text { dojam prezasićenosti } \\
\text { istim izrazima }\end{array}$ & - & $\begin{array}{l}\text { imaju puno veću } \\
\text { frekvenciju } \\
\text { pojavljivanja u } \\
\text { diskursu te ostavljaju } \\
\text { dojam prezasićenosti } \\
\text { diskursa }\end{array}$ \\
\hline
\end{tabular}

Prema navedenom, poštapalice ne bi predstavljaje podvrstu diskursnih oznaka jer ne zadržavaju neka od najbitnijih obilježja kategorije diskursnih oznaka poput vezivnosti i modalnosti. One bi time predstavljale daljnji korak u njihovu razvoju, pri čemu može doći i do tzv. depragmatikalizacije, tj. do gubljenja tekstualno-diskurzivnih funkcija DO-a (oni prestaju biti konektorima i popunjivačima diskursa i cjepkaju ga), dok interpersonalne funkcije postaju hiperpersonalnim i automatiziranim, s naglaskom na fatičkoj komunikaciji koja potiskuje ekspresivne i konativne oblike. 
Nastavljajući se na teoriju Traugott i Dasher (2005) i našu prethodnu tablicu (tablica 5), promjene nastale gramatikalizacijom diskursnih funkcija odvijale bi se na sljedeći način:

- Osjetljivost na istinitosne uvjete prelazi u istinitosnu neuvjetovanost.

- Semantičko značenje pretvara se u semantičku jezgru s pragmatičkim značenjem. Nakon toga nestaje i jezgreno značenje, a zadržano je isključivo pragmatičko, tj. proceduralno značenje. Postupno može doći i do korozije pragmatičkog značenja (modalnosti i vezivnosti) zbog pretjerane upotrebe, pri čemu će se zadržati eventualno fatički (uljudnost) i sociokulturni (identitetski) aspekti.

- Doseg značenja diskursnih oznaka postepeno će se širiti s iskaza na čitav diskurs, dok će u slučaju poštapalica on posve nestati zbog njihova manjkava značenja. S druge strane, doseg poštapalica može prijeći u socijalnu i simboličku domenu gdje će njihova upotreba naznačiti obilježja nečijeg identiteta.

- Naposljetku, proces subjektifikacije neće završiti na intersubjektivnim značenjima, već će se protegnuti u hipersubjektivirana ${ }^{91}$ značenja.

Kao što i Vrljić navodi (2007: 60), sam termin poštapalica već nam otkriva mnogo o ovoj kategoriji jezičnih izraza:

„Štap u ruke uzimamo onda kada sami nemamo dovoljno snage ustrajati u hodu do konačnog cilja pa smo prisiljeni oslanjati se na štap, poštapati se."

Iz istog razloga korisno je pogledati i terminologiju u engleskom jeziku koja je, čini se, često i uzrok krivih interpretacija spoznaja o poštapalicama u odnosu na diskursne oznake, preuzetih iz inozemnih znanstvenih radova. Najbliži termin hrvatskom terminu poštapalica na engleskom bi jeziku bio termin crutch word, u doslovnom prijevodu "riječ štaka", tj. poštapalica. Ipak, često se može pronaći i naziv filler word, tj. popunjivač, što bi zapravo bila podvrsta u kategoriji diskursnih oznaka, a ne poštapalica. Naime, poštapalica ima tendenciju popunjavanja svih dostupnih praznina u diskursu, čime ga cjepka, dok ga istinski popunjivači ispunjavaju svjesno, na strateškim mjestima time ga povezujući u cjelinu. Također, neki autori poput Vrljića (2007: 64) termin poštapalica prevode kao hesitation form, tj. oblik oklijevanja. To ponovno ne opisuje odliku poštapalica, već diskursnih oznaka u vidu popunjivača koji nastaju s namjerom (dobivanja na vremenu), dok se poštapalice koriste automatizmom (zbog manjka znanja). Na posljetku, javlja se i termin prop word, što bi u prijevodu na hrvatski značilo "riječ rekvizit" jer potpomaže u čemu, tj. podupire već postojeće elemente te najčešće dolaze iz skupine

\footnotetext{
${ }^{91}$ Po uzoru na Josepha Walthera i njegov pojam hiperpersonalne komunikacije.
} 
deiktičnih $^{92}$ izraza. S obzirom na uvedenu distinkciju između diskursnih oznaka i poštapalica, sami smo se odlučili za podupiranje engleskih termina crutch i prop word, dok popunjivače kao i oblike oklijevanja ostavljamo za opis diskursnih oznaka.

Zanimljivo je da Vrljić (2007: 61) za razliku od ostalih autora uvažava disruptivnu ulogu poštapalica u nekom diskursu i time ih odmiče od kategorije DO-a:

„... poštapalice se u hrvatskom jeziku rabe kao riječi bez značenja, "prazne” riječi. Takva uporaba riječi bez stvarne potrebe stvara buku u komunikacijskom kanalu čime se otežava dolazak informacije od govornika do slušatelja..."

S time bismo se složili i tako se odmakli od proturječnih tvrdnji autora poput Dolić (2016: 85) koja navodi da poštapalice mogu imati kako bogat tako i siromašan fond, te da prikrivaju pauze u diskursu s ciljem njegova povezivanja. Naime, ako bi poštapalice imale bogat fond, onda bi izguble svoje obilježje povećane frekvencije i potpune desemantizacije i radilo bi se o diskursnim oznakama. Također, iako poštapalice popunjavaju pauze u diskursu, one za razliku od DO-a to ne čine uspješno, već ga kidaju na manje dijelove. Naposljetku, možemo zaključiti da se ne možemo složiti s tvrdnjom da su u slučaju poštapalica zadovoljeni svi formalni kriteriji primijenjivi na kategoriju diskursnih oznaka, što smo prikazali tablicom 5 i grafičkim prikazom 11.

Možda je iz svih navedenih razloga najrelevantniji aspekt poštapalica onaj sociokulturni koji zadržava određenu pragmatičnu vrijednost. One na taj način postaju sredstvom izvođenja osobnog i/ili grupnog identiteta ukazujući na razne socijalne varijable poput dobi, roda, klasne i (sub)kulturne pripadnosti.

\subsubsection{Diskursne oznake vs. dijalogičnost šutnje}

U prethodnom smo podnaslovu razmotrili poštapalice u odnosu na kategoriju diskursnih oznaka te smo zaključili da su zbog svojeg dijakronijskog razvoja iz kategorije diskursnih oznaka poštapalice često, ali pogrešno i same svrstavane u tu kategoriju, iako s njome više ne dijele neke od osnovnih obilježja. S obzirom na takve spoznaje, uočena je potreba za pridavanjem pažnje onome što se doima suprotnim od buke u komunikacijskom kanalu (suprotnom od poštapalica), a to je dijalogična šutnja. Naime, poštapalice bi predstavljale

\footnotetext{
${ }^{92}$ Irena Zovko (1999) pozabavila se upotrebom riječi ono u svakodnevnom govoru mladih. Spomenuta deiksa pokazala se iznimno polisemantičnom i ovisnom o kontekstu i najčešće je obnašala funkciju poštapalice.
} 
krajnju fazu procesa gramatikalizacije i subjektifikacije, fazu buke u kanalu pri kojoj se gubi sistematičnost i praktičnost jezika. No, ako na završetku imamo buku, u sredini sistematiziran jezik, postavlja se pitanje što bi trebalo stajati na početku. Što je prethodilo diskursnim oznakama (osim punoznačnih riječi) ako nakon njih slijedi buka? Može li se govoriti o neverbalnim ili parajezičnim diskursnim oznakama i može li to biti šutnja?

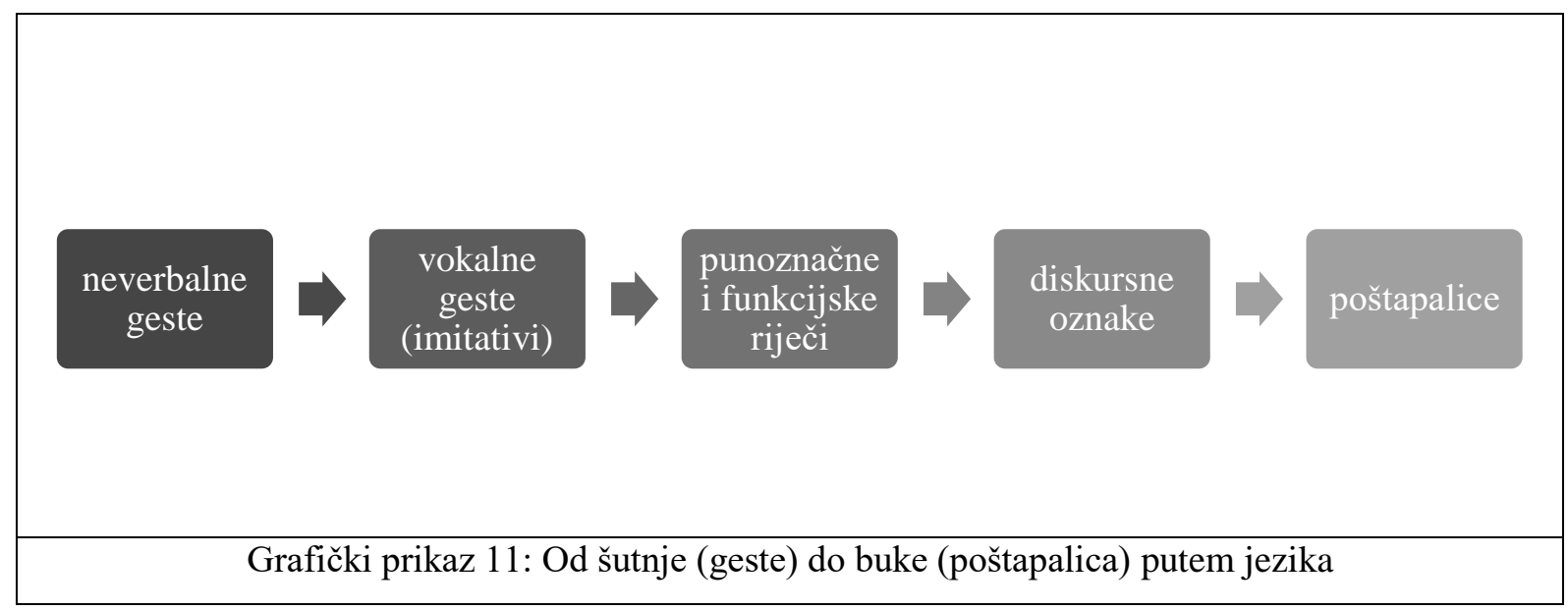

Govoreći o šutnji, napominjemo da ovdje mislimo na svjesnu i intencionalnu upotrebu šutnje u diskursu, šutnju u sklopu komunikacijske interakcije, tj. šutnju kao oblik neverbalne komunikacije. Postoje različiti oblici šutnje s obzirom na njezine oblike i funkcije, stoga u dijalogičnu šutnju ubrajamo: geste, ograde, elokventnu šutnju i pauze. U sklopu cyberkomunikacije primjer šutnje u vidu geste može biti specifičan emotikon ili gif koji nam vizualnim putem prenosi poruku (npr. emoji lica bez usta koji ukazuje na šutnju), šutnja u funkciji ograde ovdje se obično manifestira u vidu trotočja, razmaka ili novog reda u pisanju. Elokventna šutnja nešto je kompleksnija i uz semiološki aspekt u sebi sadrži sociokulturne i afektivne aspekte značenja, zato ovdje ubrajamo svaki oblik institucionalizirane šutnje, tretman šutnjom i ostanak bez riječi. Elokventna se šutnja u tome smislu može analizirati i u sklopu teorije govornih činova. Naposljetku, šutnja se može pojaviti u obliku praznih i popunjenih pauzi, pri čemu prazne pauze mogu ukazivati na razmišljanje i održavanje retoričke kontrole, a one popunjene na stil i na kontekst upotrebe. Time postaje jasno da funkcije šutnje i oblici u kojima se javlja imaju mnogo podudarnosti s kategorijom diskursnih oznaka (mnogo više nego kategorija poštapalica) i moguće ih je rasporediti u sve dosad predložene podvrste diskursnih oznaka. Na taj bi način geste i elokventna šutnja odgovarale potskupini interaktiva i modifikatora, dok bi ograde i pauze pale u skupinu konektora i popunjivača. 
S obzirom na to da smo se pri klasifikaciji diskursnih oznaka (na konektore, popunjivače, interaktive i modifikatore) navodili Jakobsonovim komunikacijskim funkcijama jezika, to ćemo kao i Ephratt (2008) primijeniti na klasificiranje oblika šutnje. Klasifikacija je vidljiva iz primjera koji slijede.

i. Elokventna šutnja - šutnja s naglašenom referencijalnom funkcijom. Primjer ovakva oblika šutnje u sklopu cyber-komunikacije bio bi tretman šutnjom koji je uočljiv zbog vidljivosti točnog vremena kada je poruka poslana i je li na nju dan odgovor i ako jest, kada. U ekstremnim slučajevima, kada osoba u potpunosti prekine sve oblike komunikacije s drugom osobom s kojom je do tada održavala kontakte, dolazi do tzv. ghosting-a. ${ }^{93}$

ii. Šutnja s istaknutom ekspresivnom funkcijom u cyber-komunikaciji često se manifestira kao neverbalna gesta: emotikonima, emojijima i gifovima ili kao vokalna gesta u vidu imitativa (npr. pssst).

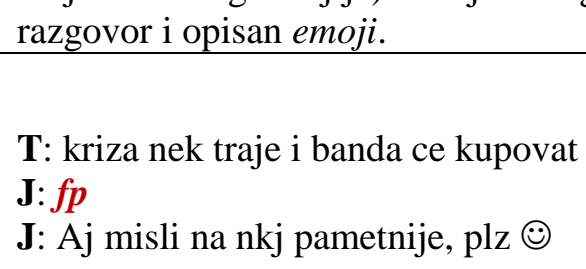
razgovor i opisan emoji.

T: kriza nek traje i banda ce kupovat

$\mathbf{J}: f p$

J: Aj misli na nkj pametnije, plz :) lica dlanom, zatvarajući i prekrivajući oči, sa značenjem razočarenja, srama, frustracije ili sarkazma. Na engleskom jeziku to pokriva izraz facepalm, ponekad korišten kao kratica $f p$ umjesto samog emojija). Ovdje smo ga time zamijenili, no u prilogu 13 vidljiv je originalni

iii. Šrutnja u konativnoj funkciji prije svega obnaša proceduralnu ulogu. To je ona šutnja koja dolazi na granicama iskaza i pripada strukturi diskursa u domeni dijaloga (Ephratt 2008: 1920). Ovdje također ubrajamo i šutnju iz uljudnosti, šutnju kao izraz slaganja, kao retoričko pitanje ili kao uvažavanje tabua.

\footnotetext{
${ }^{93}$ Dostupno na URL: https://www.urbandictionary.com/define.php?term=Ghosting (14. 7. 2020.)
} 
iv.

Primjer 14: Šutnja u proceduralnoj funkciji (upotreba trotočja s ciljem strukturiranja diskursa. Može se interpretirati kao konativna (u dijalozima) i kao metajezična. Ova bi se trotočja mogla interpetirati kao ograde (engl. hedges) i svrstati se u podvrstu konektora i popunjivača diskursa.

J: Pa da, veselis se tome :-

T: a cekat cu bar jos 5 tjedana! tak da...

J: Znaci koristit ces na jesen :-

J: Tj zimu... ak ovo ne splasne

v. Fatička funkcija šutnje suprotna je Leechovoj fatičkoj maksimi (Nastavi pričati. Izbjegavaj šutnju.) kao i konceptu praznog govora koji odlikuju poštapalice. Ona glasi: Prestani pričati. / Izbjegavaj govor., a mogu je realizirati samo međusobno bliske osobe koje će se i na taj način razumijeti.

vi. Šutnja se u poetskoj funkciji orijentira prema estetskom doživljaju primatelja poruke. Ona jednako tako može sadržavati i ludičke elemente.

vii. Naposljetku, dominacija metajezične funkcije u šutnji dolazi na vidjelo kada ne razumijemo jezik, kada se njome ističe prozodija, kada se prešućuje (briše) agens nakon pasivizacije iskaza, kada imamo pravo na šutnju i kada šutnjom strukturiramo diskurs (preklapanje s proceduralnim aspektom konativne funkcije).

Primjer 15: Šutnja u ekspresivnoj i konativnoj funkciji (upitnici kao znak zbunjenosti, osupnutosti, čuđenja i/ili traženja objašnjenja).

J: Upravo sam razgovarala sa svojim Mac-om (:) ;) zove se Siri i odgovara mi ženskim glasom, british english

J: Osjećam se ko u crvenom patuljku, da pricam s holly $: ;$

T: ???

J: Ima voice recognition i odgovara ti

Iako za šutnju ne možemo tvrditi da predstavlja izvor diskursnih oznaka, njezina gestovna priroda i simbolički potencijal otvaraju mogućnost da je označimo kao vrlo plodan izvor neverbalnih i parajezičnih diskursnih oznaka. Njezina nam analiza i uočene funkcije otkrivaju dvije relevantne spoznaje. Ističe se činjenica da se šutnja u sklopu (dijaloške) komunikacije može pojaviti i obično se javlja u vidu diskursnih oznaka. Ovisno o komunikacijskoj funkciji 
koja je njome istaknuta, šutnja će u dijalogu najčešće ući u jednu od podvsta kategorija diskursnih oznaka: konektore (...), popunjivače, interaktive (???) ili modifikatore (emoji). Također, promatrajući šutnju kao vrstu geste i parajezika, do izražaja dolazi njezina potencijalna uloga i značaj za teorije jezične evolucije jer je ljudska komunikacija polisemiotična (verbalna i neverbalna, te simbolična, ikonična i indeksična). Naposljetku, zahtjev komunikacije za šutnjom ogleda se i u utjelovljenosti jezika koju prati odgovarajuća struktura. ${ }^{94}$

S ciljem boljeg shvaćanja kategorije diskursnih oznaka, petim smo poglavljem nastojali doprinijeti ovoj temi kroz prizmu evolucijske pragmatike i primjerima jezične promjene iz cyber-diskursa. Time smo se dotakli i nekih velikih problema i stoljetnih filozofskih prijepora između nativizma i emergentizma, kao i pitanja sociosemiološkog porijekla jezika. Također, raspravljalo se o problemu značenja kategorije diskursnih oznaka, gramatikalizaciji, subjektifikaciji te kategoriji poštapalica i dijalogične šutnje u odnosu na DO-e. Naposljetku, sve smo zaključili ukazivanjem na velik komnunikacijski potencijal šutnje koja predstavlja most između verbalnog i neverbalnog, te na evolucijsku povezanost nejezičnog, parajezičnog i jezičnog koju prožima i motivira upotreba. Samim time došli smo i do sljedećeg naslova koji nam donosi osnovna saznanja i nove spoznaje stečene konkretnim analizama i teorijskim promišljanjima koje su se iskristalizirale pisanjem ovog rada.

\footnotetext{
${ }^{94}$ To podupire konverzacijska analiza naglašavajući relevantnost šutnje pri strukturiranju dijaloga (izmjenjivanja redova u govorenju).
} 


\section{5. „MEDIJI KAO ČOVJEKOVI PRODUŽECI” ILI BUKA U KOMUNIKACIJSKOM KANALU? (rezultati i rasprava)}

Kao (nekoć) novi medij internet $u$ današnje vrijeme dominira sferom razmjene informacija. No osim što utječe na sam oblik komunikacije i njezine sudionike, on utječe i na poruku. $\mathrm{Na}$ takvo je obilježje medija upozoravao Marshall McLuhan (2008: 14) u svojoj poznatoj sintagmi medij je poruka:

„Naime, "poruka” svakog medija ili tehnologije jest promjena razmjera, brzine ili uzorka koje unosi u ljudske odnose."

Drugim riječima, medij osim sadržaja poruke prenosi i poruku (informacije) o njezinom pošiljatelju (npr. koliko mu je prilagođen) i o samome sebi (npr. koliko je učinkovit). Sve su te poruke relevantne za razumijevanje i savladavanje (cyber-)komunikacije, za što je potrebna svojevrsna pismenost. I na to je također ukazao McLuhan (2008: 20) govoreći o nužnosti opismenjivanja zbog dvaju osnovnih obilježja medija. Zbog njihove dostupnosti:

„Električna brzina miješa pretpovijesne kulture s talogom industrijskih prodavača, nepismenih s polupismenima i poslijepismenima."

i zbog njihove preplavljenosti informacijama:

"Duševni slom različitih stupnjeva veoma je česta posljedica iskorjenjavanja i preplavljivanja novim informacijama i beskrajnim novim uzorcima informacija."

Iz navedenih razloga javlja se potreba za uvažavanjem i poticanjem cyber-pismenosti ${ }^{95}$, a time i za postavljanjem principa cyber-pragmatike, o čemu će biti riječi u podnaslovu koji slijedi.

Naposljetku, McLuhan nas upućuje i na to da su mediji čovjekovi produžeci jer se oni ne javljaju na razini mišljenja ili koncepcija, već mijenjaju osjetilne razmjere ili načine opažanja (2008: 22). Iz takve bismo tvrdnje (kao i one prethodne o nužnosti opismenjavanja i razumijevanja prirode medija) mogli izvući zaključak da mediji zaista jesu čovjekovi produžeci, no iz njihove upotrebe mogu izaći kako pozitivni tako i negativni učinci. U pozitivnom smislu mediji će nam biti korisni produžeci ako ih razumijemo i savladamo, u suprotnom ćemo u njima vidjeti kaotičnost i sami širiti buku.

\footnotetext{
${ }^{95}$ Više o problemu cyber-pismenosti u podnaslovu 2. Komunikacijska kompetencija u cyber-svijetu.
} 


\section{1. Diskursne oznake - moderatori u kaosu iskaza (interpretacija kvalitativnih podataka i verifikacija postavljenih hipoteza)}

Osnovne pretpostavke ovog rada postavljene na samome početku u prvom se redu odnose na problematiku diskursnih oznaka, točnije na nekoliko aktualnih tema toga područja. Osnovna pitanja koja su bila postavljena sljedeća su: koje sve funkcije diskursne oznake mogu obnašati?, u kojim se oblicima mogu javljati?, što jesu a što nisu diskursne oznake?, kako nastaju diskursne oznake? i u što mogu evoluirati? Na temelju tih pitanja i u odnosu na kontekst istraživanja, tj. cyber-diskurs, hipoteze su bile uobličene na sljedeći način:

H1 - Skraćenice i imitativi cyber-diskursa često obnašaju funkciju diskursnih oznaka zbog vlastite ekonomičnosti i zbog dočaravanja komunikacije licem u lice kao i parajezika koji je prati.

Analizom je uočeno i potvrđeno da to zaista jest slučaj. Skraćenice često prelaze u kategoriju diskursnih oznaka jer su ekonomične: brzo su upotrebljive te mogu izvršavati sve funkcije diskursnih oznaka (kako tekstualne tako i one interpersonalne). Također, ovdje fonološko kraćenje (kao jedno od glavnih obilježja) pri procesu nastanka diskursnih oznaka dolazi na vidjelo, no u pisanom obliku. S druge strane, imitativi (zbog visoke razine vlastite ikoničnosti) prenose neverbalne komunikacijske migove koji upućuju na željenu interpretaciju iskaza i dočaravaju osjećaj komunikacije licem u lice. Posljedično tome, takva im inherentna obilježja otvaraju širok prostor u kategoriji diskursnih oznaka.

H2 - Paralingvističke informacije u tipovima cyber-komunikacije zasnovanim isključivo na mediju teksta (poput instant poruka i chata) također se bilježe pismom kao i one lingvističke. Stoga šutnja [...] i buka [AAAA] i ostali parajezični fenomeni mogu biti analizirani kao pragmatičke funkcije.

Verifikacija druge pretpostavke vidljiva je iz analize primjera šutnje i poštapalica u poglavlju 5. Zbog eksplicitnog bilježenja neverbalnih aspekata komunikacije, u sklopu mrežnog diskursa takva se pragmatička analiza parajezika pokazala mogućom. Ona je također dovela do nove spoznaje, ukazujući na još jedno obilježje kategorije diskursnih oznaka. To nam obilježje govori 
da DO-e nisu samo polifunkcionalne, već i heterosemiotične ( $\mathrm{tj}$. da dolaze iz različitih semiotičkih sustava, ne samo jezika).

H3 - Diskursne oznake u cyber-komunikaciji često nastaju na mjestima lingvističke (elokventne) šutnje s istaknutom ekspresivnom ili fatičkom funkcijom.

Pretpostavka pod rednim brojem 3 nije se pokazala u potpunosti točnom, no procesom analize lingvističke šutnje došlo se do drugih vrijednih saznanja. Utvrdilo se da se šutnja može pronaći u svim komunikacijskim funkcijama jezika pa tako i u svim potkategorijama diskursnih oznaka. Njezina eskpresivna i fatička funkcija doći će do izražaja, no jednako su naglašeni njezini konativni i metajezični aspekti (posebice za strukturiranje diskursa) kao i njezin estetski potencijal.

H4 - Diskursne oznake mogu evoluirati u poštapalice. Poštapalice time ne čine zasebnu potkategoriju diskursnih oznaka (jer narušavaju diskursnu koherentnost), već predstavljaju razvoj i jedan od produkata dijakronijskog procesa gramatikalizacije diskursnih funkcija.

Posljednja pretpostavka verificirana je i obrazložena u podnaslovu 5.4. Pojašnjeno je i oprimjereno da kategorija poštapalica ne spada u skupinu diskursnih oznaka jer narušava neke od njezinih osnovnih obilježja poput ispunjavanja zahtjeva za ostvarenjem diskursne koherentnosti. Drugim riječima, među osnovnim je obilježjima kategorije diskursnih oznaka njihova karakteristika da povezuju diskurs (na smislenoj i tekstnoj razini), dok poštapalice čine upravo suprotno, cjepkajući ga na manje dijelove i narušavajući mu smislenost. Ipak, takvo često, ali pogrešno svrstavanje poštapalica u skupinu diskursnih oznaka vjerojatno leži u njhovoj međusobnoj povezanosti na dijakronijskoj razini: u procesu procesu gramatikalizacije diskursnih funkcija koji vodi k potpunoj desemantizaciji izraza i u procesu subjektifikacije koji vodi do njegove idiomatizacije.

Razmatranje relazultata provedene analize kao i iščitavanje relevantne literature također je dovelo do općenitijih saznanja koja sežu onkraj postavljenih hipoteza. U to bismo svakako ubrojili našu sistematizaciju funkcija diskursnih oznaka sukladno kojoj je razrađena njihova potkategorizacija. Osim toga, ukazano je na raznolikost oblika u kojima se diskursne oznake 
mogu pojaviti, što (kako se pokazalo) nije ograničeno isključivo na jezik te prelazi u ostale semiotičke sustave. Za sam kraj, istaknuta je relevantnost uvažavanja i postojanja evolucijskih promjena na diskursnoj razni, a one mogu mnogo reći o obilježjima specifičnih jedinica diskursa (poput poštapalica), ali i o prirodi jezičnog razvoja općenito. Time je dan poticaj za oživljavanje pragmatičkih teorija jezične evolucije koje prednost daju prilagodbi i upotrebi, svraćajući dugogodišnju pozornost s nativističkih pristupa. Takve teorije osnovne razloge za jezičnu prilagodbu vide u promjenama konteksta: u promjeni fizičke okoline, u promjeni sociokulturne strukture i u promjeni standarda jezične upotrebe, što se dogodilo usponom digitalnog društva. Prešlo se iz fizičkog u virtualni svijet (promjena okoline), promijenili su se sociokulturni uvijeti (povećala se anonimnost, mogućnost participacije i povezivanja ljudi, došlo je do umnažanja identiteta i formiranja pseudoidentiteta i hiperpersonalnosti) i formirao se novi oblik pismenosti (cyber-pismenost). Naposljetku, ovakvi dinamični modeli jezične evolucije u svojoj jezgri sadrže pretpostavku o važnosti upotrebe i funkcionalnosti komunikacije za jezičnu evoluciju. Pri tome na vidjelo dolazi i dugo zanemarivana srodnost, povezanost i sličnost ljudske i životinjske komunikacije, utjelovljena priroda jezika i potencijalno gestovno porijeklo jezika.

\section{2. Kreativnost, pragmatizam i sociosemiotika cyber-komunikacije}

„Linguistic creativity is not simply a property of exceptional people, but an exceptional property of all people." (Carter 2004: 13)

Kreativnost jezika u upotrebi percipira se kao nov, namjeravan (u smislu posjedovanja vrijednosti ${ }^{96}$ ) i svrsishodan način formiranja komunikacijskih značenja i namjera. Ipak, u skladu s Peirceovom semiotikom, kreativnost je ograničena kontekstom. Taj isti kontekst s druge strane osigurava da noviteti budu funkcionalni (imaju vrijednost), tj. da ih se može razumjeti.

Zbog toga smatramo da su neki od sljedećih razloga upravo oni koji pokreću i uzrokuju kreativnost u komunikaciji: ograničeni repertoar standardiziranih značenja, društveni učinci i pragmatičke prepreke (npr. zadovoljavanje uvjeta novog kanala da bi se omogućio nesmetan

\footnotetext{
${ }^{96}$ Ta vrijednost ne mora nužno biti estetska, može biti i pragmatička.
} 
tijek informacija). Preciznije rečeno, svrha kreativnosti u jeziku može biti promjena kuta gledišta na sadržaj poruke, humor, naglašavanje, ekspresivnost, formiranje i manifestacija identiteta, zabava, bilježenje preuzimanja reda u govorenju ili stimuliranje tijeka razgovora. (Atkins \& Carter, 2012).

Zbog svega navedenog sa sigurnošću možemo reći da je upotreba kratica u sklopu cyberkomunikacije (diskursne oznake i imitativi) solidan primjer jezične kreativnosti jer se one zaista mogu upotrijebiti na svaki od gore nabrojanih načina. To je također mjesto gdje je vidljiva i polifunkcionalnost diskursnih oznaka.

Naposljetku, napomenut ćemo još dvije povezane značajke računalno-posredovane komunikacije koje uzrokuju i utječu na jezičnu kreativnost: zasićenost informacijama (uzrokovana brzinom njihova prijenosa i produkcije) i njihov širok doseg (povezivanje i dostupnost informacija različitim publikama). Na sam dojam informacijske zasićenosti u cyberkomunikaciji može utjecati i njezina multimodalnost koja s druge strane otvara dodatne mogućnosti za kreativni izražaj.

S obzirom na brzinu kojom se suvremeni svijet mijenja (npr. nove komunikacijske tehnologije) potreban nam je mehanizam s pomoću kojeg ćemo se nositi s izazovima u našoj okolini na nove i odgovarajuće načine, a taj je mehanizam kreativnost. Ona već nebrojeni niz godina, štoviše milenija savršeno funkcionira kao dio ljudske prirode i ne tiče se samo jezika kao jednog od znakovnih sustava kojm se čovjek služi. Činjenicu da neki i dalje ne vide vrijednost u nestandardnim jezičnim oblicima i specifičnim obilježjima digitalnog diskursa koji jesu posljedica te kreativnosti možemo objasniti strahom od promjene, nedostatkom (praktičnog) znanja i frustracijom uzrokovanom nemogućnošću pristupa (računalnom) diskursu. S obzirom na to da je mrežna komunikacija još uvijek donekle slobodna od jezičnog planiranja i podložna je brzim promjenama, cyber-diksurs je jedno od savršenih mjesta za istraživanje kreativnosti i jezičnih promjena.

Uz jezičnu kreativnost i dinamičnu prirodu komunikacije u cyber-prostoru svakako treba uvažiti njezin pragmatizam ${ }^{97}$ i njezine sociosemiološke aspekte. U tom pothvatu pomoći će prethodne spoznaje o utjelovljenosti komunikacije, važnosti interakcije i upotrebe za formiranje značenja te o spoznajama o parajeziku. Slično prijedlozima Horsta Ruthorfa (2007) u njegovim

\footnotetext{
${ }^{97}$ Pragmatizam u smislu praktične vrijednosti, korisnosti koja proizlazi iz upotrebe.
} 
nacrtima korporealne ${ }^{98}$ pragmatike i slijedeći McLuhana, cyber-pragmatika morala bi uvažavati značaj percepcije i interakcije (za formiranje značenja), što je potpomognuto uvidima iz Peirceove semiotike o ikoničnoj prirodi jezika (Nöth: 2001) i fenomenološkim tumačenjem percepcije i značenja kao uvijek posredovanog tijelom, utjelovljenog.

Cyber-pragmatika bi uz to trebala imati postavljene osnovne principe koje je uvijek potrebno imati na umu:

- Prvi bi se princip ticao odnosa prema semantici prirodnih jezika, pri čemu cyberpragmatika ističe da je značenje potrebno i nužno proučavati kao uvjetovano upotrebom Posljedično tome, cyber-pragmatika bavila bi se ostvarenim iskazima u realnim kontekstima. Bavila bi se smislom a ne značenjem, iskazima a ne rečenicama.

- Drugi princip ukazuje na odnos prema tradicionalnom viđenju gramatike. Njime se tvrdi da priroda cyber-diskursa i komunikacije zahtijeva proširenje tradicionalnog poimanja gramatike (onkraj dominantne sintaktičke razine) radi obuhvatnije i točnije analize $\mathrm{i}$ interpretacije podataka. Ovo se načelo ogleda u zahtjevu za transfrastičkom gramatikom i u primjeru teorije s takvim potencijalom poput funkcionalne diskursne gramatike. ${ }^{99}$

- Sljedeći princip nalaže shvaćanje ljudske komunikacije kao polisemiotičnog sustava, tj. znakovnog sustava koji se ne sastoji samo od verbalne komunikacije i prirodnog jezika, već sadrži i neverbalni prijenos informacija u različitim oblicima (simbol, signal, ikona). Ovdje do izražaja dolazi ikonična priroda jezika koja je u cyber-komunikaciji najočitija u prijenosu neverbalnih migova i parajezika (npr. emotikoni i imitativi).

- Četvrti princip pretpostavlja nužnost utjelovljenosti jezika. Jezik je shvaćen kao direkcionalan i ostenzivan, što se smatra ostacima gestovne protosemioze. Time se cyber-pragmatika oslanja na fenomenološka objašnjenja jezičnog razvoja poput teorija gestovnog porijekla jezika.

- Peti princip upućuje na polifunkcionalnost jezika koju uvijek treba imati na umu, jer se jezikom ne prenose samo referencijalna značenja.

- Šestim principom cyber-pragmatika naglašava utjecaj medija (interneta) na prirodu komunikacije, što mora biti sastavni dio svake analize.

\footnotetext{
${ }^{98}$ Korporealna pragmatika kao grana pragmatike koja naglasak stavlja na utjelovljenu, tj. tjelesnu (i o tijelu ovisnu) prirodu ljudske komunikacije.

${ }^{99}$ Vidi poglavlje 3.5. Diskurs i gramatika - diskursna (transfrastička) gramatika?
} 
- Posljednji princip iskazuje zahtjev za multidisciplinarnošću, interdisciplinarnošću i transdisciplinarnošću (npr. sociolingvistika, semiotika, korpusna i računalna lingvistika, računarstvo). 


\section{ZAKLJUČAK}

\section{1. Najvažniji rezultati i nove spoznaje}

Diskursne oznake i kontekst cyber-diskursa pokazali su se kompleksnim temama za koje je bilo neophodno mnogo uvoda ne bi li se adekvatno obradile. Iako se njima (diskursnim oznakama u cyber-komunikaciji) koristimo svakodnevno i s lakoćom, njihove je funkcije i oblike trebalo detaljno promisliti na objema osima jezičnog sustava: sinkronijskoj i dijakronijskoj i pomoći si raznovrsnim teorijama ${ }^{100}$ i metodološkim okvirima.

U prvom dijelu rada (poglavlje 2) bavili smo se komunikacijskom kompetencijom u cybersvijetu i važnosti diskursnih oznaka pri koordiniranju komunikacijskog procesa. Isprva smo pojasnili pojam komunikacijske kompetencije u općem smislu, da bismo ga potom smjestili u kontekst mreže. Potom smo objasnili ulogu i važnost diskursnih oznaka za uspješnu komunikaciju i pružili pregled najrelevantnijih teorijsko-metodoloških pristupa diskursnim oznakama, kako u svjetskoj tako i u regionalnoj te domaćoj literaturi. Smatramo da se najveći doprinos ovog dijela rada ogleda u definiranju koncepta cyber-pismenosti koji za sada nije dobivao previše pažnje, posebice u sklopu hrvatskog jezikoslovlja. Naposljetku, vlastitom brikolažnom tehnikom vjerujemo da smo na inovativan način započeli formiranje teorijskometodološkog okvira koji će biti pogodan za izučavanje elemenata diskursne razine (poput DOa), gradeći na nasljeđu kako stranih, tako i domaćih znanstvenika.

U drugome dijelu (poglavlje 3) odredili smo područje i predmet cyber-pragmatike, pri čemu smo se koncentrirali na tri osnovna problema. Problem kojim smo otvorili poglavlje bavio se određenjem i pojašnjenjem terminologije ovog područja (cyber vs. kiber), za koji smatramo da nije nimalo banalan, već iznimno relevantan za shvaćanje i bavljenje komunikacijom na mreži u sklopu hrvatskog jezika. Nakon toga su uslijedili prijedlozi metodoloških okvira koji bi bili pogodni za cyber-pragmatička istraživanja. Tu su uvršteni prilagođeni tradicionalni pristupi diskursne analize poput konverzacijske analize i analize govornih činova, dok je s druge strane predloženo osmišljanje i implementacija suvremenih (CMDA - Computer-mediated Discourse Analysis), eklektičnih i transdisciplinarnih (multimodalnih i kvantitativnih) metoda u studije cyber-komunikacije. Na završetku poglavlja također se nastojalo ukazati na manjkavosti

\footnotetext{
${ }^{100}$ Poput pragmatike, sociolingvistike, analize diskursa, konverzacijske analize i sociosemiotike.
} 
tradicionalnih pristupa gramatici, pri čemu se zahtijevalo šire poimanje gramatike i uvidjela se potreba za osmišljanjem transfrastičkih gramatičkih modela. Inovativnost ovog segmenta rada najbolje se ocrtala u primjeru modela funkcionalne diskursne gramatike koja prema našem sudu (za sada) predstavlja najpogodniji i najrazrađeniji transfrastički gramatički model. Potencijal FDG-a s vremenom se sve više otkriva u radovima međunarodne lingvističke akademske zajednice, kako na sinkronijskoj tako i na osi dijakronije. Recentniji primjer toga zasigurno je istraživanje i doktorska disertacija Riccarda Giomija pod nazivom Shifting structures, concepts and meanings: A Functional Discourse Grammar account of grammaticalization iz 2020. godine.

Treći je dio rada (poglavlje 4) u fokusu imao kategoriju diskursnih oznaka u sinkronijskom presjeku. Još se detaljnije raspravljalo o terminološkim problemima koji prate ovu kategoriju, utvrđivali su se formalni kriteriji za određenje kategorije, te funkcije i (pod)vrste diskursnih oznaka. Sve je bilo potkrijepljeno primjerima iz ciljnog i/ili referentnog mrežnog korpusa, koji je opisan kao i aspekti etičnosti provođenja ovakvog tipa istraživanja. Vjerujemo da smo tim poglavljem uspješno pružili primjere diskursne analize u kontekstu cyber-komunikacije, prikazali njezine posebnosti, prednosti i potencijale. Također smatramo da smo na inovativan način ukazali na značaj i ravnopravan odnos funkcije i forme za lingvistička istraživanja.

U četvrtom se dijelu rada (poglavlje 5) težište prebacilo na dijakronijski razvoj diskursa i jezika. Istaknuta je važnost, zanemareni potencijal i dosadašnja uloga historijske pragmatike, utjelovljenost ljudske spoznaje i uvažavanje neverbalnih aspekata komunikacije. U konkretnim primjerima su s mreže prikazane semantičko-pragmatičke promjene jezičnih jedinica $\mathrm{s}$ diskursne razine, što je razjašnjeno procesima gamatikalizacije i subjektifikacije. Originalnost spoznaja ove cjeline iskristalizirala se u nekoliko novih spoznaja. U prvome redu to bi bilo izdvajanje poštapalica iz kategorije diskursnih oznaka temeljem njihovih formalnih obilježja, funkcija i postanka. Nadalje, analiza je pokazala da diskursne oznake nisu samo polifunkcionalne, već i heterosemiotične. Treći doprinos ogledao se u analizi šutnje, koja se pokazala mostom između verbalnog $\mathrm{i}$ neverbalnog, te polifunkcionalnom $\mathrm{u}$ smislu komunikacijskih funkcija koje može obnašati.

U raspravi, tj. petome dijelu rada (poglavlje 6) verificirale su se postavljene hipoteze i postavili principi cyber-pragmatike. Pri tome vjerujemo da postavljeni principi cyberpragmatike predstavljaju neophodne temelje nove discipline u pitanju te oslikavaju nužnu inovaciju za adekvatnu analizu suvremene komunikacije. 
S obzirom na to da se u pisanje rada krenulo postavljanjem osnovnih ciljeva i svrhe rada, ovdje ćemo ih ponoviti ne bi li vidjeli jesu li ostvareni i postignuti. Ovim se radom nastojalo:

- razjasniti kriterije za određenje kategorije diskursnih oznaka (sinkronija),

- naglasiti zamke epistemoloških problema struke (problem proučavanja jezične upotrebe),

- ukazati na dijakronijske (evolutivne) procese što se odvijaju na razini diskursa,

- istaknuti potrebu za funkcionalnim pristupima jeziku i važnosti širenja tradicionalnog viđenja gramatike.

Za prvi cilj, u smislu razjašnjenja kriterija za određenje kategorije diskursnih oznaka, možemo ustvrditi da je ostvaren. Pružen je kritički uvid u terminologiju užeg područja DO-a, određena su nužna obilježja kategorije, njihova definicija i njihove funkcije. Drugi je cilj postignut i ogleda se u samim rezultatima i spoznajama ovog istraživanja jer je ukazao na često neiskorišteni potencijal proučavanja jezične upotrebe, umjesto izoliranih apstraktnih jedinica u sklopu jezičnog sustava. Sljedeći je cilj, u vidu ukazivanja na dijakronijske procese diskursne razine također realiziran, što se najbolje pokazalo primjerima gramatikalizacije diskursnih funkcija i procesom subjektifikacije, tj. cjelovitim oblikovanjem diskursnih oznaka. Naposljetku, potreba za funkcionalnim pristupima jeziku i širenjem tradicionalnog viđenja gramatike isticana je čitavim radom, posebice ukazivanjem na nužnost sociosemiotičkih doprinosa lingvistici, kao i na potrebu za transfrastičkim (diskursnim) gramatikama. 


\section{2. Glavne poteškoće i sugestije za buduća istraživanja}

Osvrnemo li se još na samome kraju, na osnovne poteškoće koje su se javljale tijekom ovog istraživanja, primijetit ćemo dvije skupine problema koje su nas pratile.

Prva je skupina problema posljedica nepostojanja jedinstvene paradigme koja bi ponudila odgovarajući teorijski i metodološki okvir za istraživanja cyber-diskursa. Iako se istraživanja ovog područja s vremenom umnažaju, metodološki pristupi i teorijski okviri još uvijek uvelike ovise o pojedinačnim istraživačima, njihovu užem predmetu istraživanja i osobnim preferencijama, pri čemu se često oslanja na tradicionalne prethodnike (poput konverzacijske analize ili etnografije) koje se minimalno prilagođava novom digitalnom kontekstu. Potrebu za prilagodbom ili osmišljanjem novog teorijsko-metodološkog okvira primijetili smo iščitavanjem literature, ali i provođenjem vlastite analize, zbog čega smo nastojali pružiti potencijalni okvir za proučavanja cyber-komunikacije svojim principima cyber-pragmatike. Time se uvidjelo da, kao i u slučaju proučavanja diskursnih oznaka, većina poteškoća izvire iz problematičnog, tj. vrlo uskog viđenja gramatike. Ipak, to nimalo ne iznanađuje jer se, kako kod cyber-komunikacije tako i kod diskursnih oznaka, radi o istraživanjima diskursne razine i jezične upotrebe, a ne o istraživanjima apstraktnih jezičnih struktura izvan konteksta upotrebe. No osim zahtjeva za proširenjem tradicionalne gramatike u transfrastičkom pravcu (primjer čega bi bila funkcionalna diskursna gramatika), uviđena je i potreba za proširenjem na neverbalne aspekte komunikacije i parajezik. Tome je Susan Herring (2012) pružila svoj doprinos vrijedan spomena, u vidu e-gramatike. Autorica je fonetsku i fonološku razinu u svojoj e-gramatici zamijenila ortografskom i tipografskom, a morfološku i sintaktičku razinu nije dirala. Glavna zmjerka ovome pristupu leži u činjenici da se semantičko-pragmatički fenomeni ponovo marginaliziraju ili ne obrađuju i autorica ih ponekad svrstava pod morfosintaktičke, čak tipografske osobitnosti cyber-diskursa. Uz e-gramatiku koju predlaže Herring, zanimljiv je doprinos već spomenutog Francisca Yusa u vidu cyber-pragmatike (u užem smislu) koja u obzir uzima semiološke aspekte komunikacije i kognitivnu pragmatičku teoriju (teoriju relevantnosti). Konačno, nije na odmet spomenuti i jedan sociosemiološki pristup Malyja u suautorstvu s Blommaertom (2019), koji su predložili nacrt digitalne etnografije jezičnih krajolika. Sam Blommaert na to gleda kao na podvrstu sociolingvistike postdigitalnog doba jer se suvremeni društveni život ne odvija samo izvan mreže, već i na njoj. 
Osim navedenog, veliki je problem predstavljao malen broj stručnih publikacija na hrvatskom jeziku vezanih za temu diskursnih oznaka i kontekst računalno posredovane komunikacije. Na to se nadovezuju svi terminološki problemi začeti u anglo-saksonskoj tradiciji (govoreći o diskursnim oznakama), kao i oni koji predstavljaju posljedicu loših i neadekvatnih prijevoda.

Konačno, za proučavanje diskursnih oznaka u cyber-diskursu dostupnom se i korisnom pokazala opcija oplemenjivanja kvalitativnih podataka onima kvantitativne prirode. S obzirom na postojanje digitaliziranih jezičnih korpusa, moguće je doći do podataka o frekvencijama pojavljivanja specifičnih riječi ili fraza, o njihovim konkordancijama i kolokacijama, pa čak i dijakronijskim podacima (tredovima korištenja određene jedinice u određenom vremenskom periodu) njihove upotrebe. Jedan od boljih primjera takvog pristupa bila bi studija autorica Aaron i Torres Cacoullos (2005) pod nazivom Quantitative measures of subjectification: A variationist study of Spanish salir(se)*. U našem radu kvantitativna analiza nije bila u prvome planu, no nastojalo se ukazati na njezine potencijale u sklopu cyber-pragmatike.

Zaključno, nadamo se da smo po tom pitanju uspjeli te da smo doprinijeli ovom području, bolje ga opremivši za neka buduća istraživanja. 


\section{LITERATURA}

Aaron, Jessi Elana i Rena Torres Cacoullos (2005.) "Quantitative measures of subjectification A variationist study of Spanish salir (se)*." Cognitive linguistics. 4/16: 607-633.

Aijmer, Karin i Anne-Marie Simon-Vandenbergen (ur.) Pragmatic markers in contrast. Amsterdam; Oxford: Elsevier.

Ajana, Btihaj (2005.) „Disembodiment and cyberspace: A phnomenological approach. Electronic Journal of Sociology. 7: 1-10.

Almurashi, Wael Abdulrahman (2016.) „An Introduction to Halliday's Systemic Functional Linguistics.“ Journal for the Study of English Linguistics. 4/1: 70-80.

Aljukić, Bernes i Emina Kurtić (2013.) „Poštapalice u razgovornom bosanskom jeziku: pozicijska obilježja i funkcija poštapalica u konstrukcijskim komunikacijskim jedinicama.“ Rasprave Instituta za hrvatski jezik i jezikoslovlje, 39/2: 509-526.

Atkins, Sarah and Ronald Carter (2012.) "Creativity in speech“. In: James Paul Gee and Michael Handford (eds.), The Routledge Handbook of Disourse Analysis. London; NewYork: Routledge, Taylor and Francis group.

Austin, John Langshaw (1976.) How to do Things with Words: The William James Lectures delivered at Harvard University in 1955. Oxford; New York: Oxford University Press.

Badurina, Lada (2008.) Između redaka. Studije o tekstu i diskursu. Zagreb: Hrvatska sveučilišna naklada.

Badurina, Lada i Mihaela Matešić (2007.) „Poštapalice pod povećalom: o jednoj posebnoj 
vrsti diskursnih oznaka“. U: B. Aljukić et al. (ur.), Zbornik radova “Tuzla. Grad na zrnu soli“. Tuzla: OFF-SET.

Badurina, Lada (2010.) „Od sintakse prema suprasintaksi i dalje. Tradicionalna gramatika ili: Zašto tekst nije imao sreće s gramatikom (i gramatika s tekstom)“. U: K. Mićanović (ur.), Zbornik radova 39. seminara Zagrebačke slavističke škole. Zagreb: Filozofski fakultet.

Bagarić, Vesna i Jelena Mihaljević Djigunović (2007.) „Definiranje komunikacijske kompetencije“. Metodika, 8 (1): 84-93.

Beaugrande, de Robert-Alain i Wolfgang Ulrich Dresler (2010.) Uvod u lingvistiku teksta. Zagreb: Disput.

Beißwenger, Michael (2008.) „Situated Chat Analysis as a Window to the User's Perspective: Aspects of Temporal and Sequential Organization.“Language@Internet. URL: https://www.languageatinternet.org/articles/2008/1532 (13.04.2020.)

Bernabeu, Pablo i Paul Vogt (2015.) „Language evolution: Current status and future directions." 10th LangUE Conference proceedings, Essex, UK.

Blakemore, Diane (1992.) Understanding Utterances: An Introduction to Pragmatics. Oxford: Basil Blackwell.

Blakemore, Diane (2002.) Relevance and Linguistic Meaning: The Semantics and Pragmatics of Discourse Markers. Cambridge: CUP.

Brinton, Laurel J. (1996.) Pragmatic markers in English: Grammaticalization and discourse functions. Berlin: Mouton de Gruyter.

Bühler, Karl (2011.) Theory of Language: The Representational Function of Language. Amsterdam; Philadelphia: John Benjamins Publishing. 
Cambridge Dictionary. Dostupno na URL:

https://dictionary.cambridge.org/grammar/british-grammar/discourse-markers-so-rightokay. (19.01.2021.)

Canale, Michael (1983.) „From communicative competence to communicative language pedagogy“. U: Richards, J. C., i Schmidt, R. W. (Ur.), Language and Communication, 2-27. London: Longman.

Canale, Michael i Merrill Swain (1980.) „,Theoretical bases of communicative approaches to second language teaching and testing“. Applied Linguistics, 1, 1-47.

Carey, John (1980.) „Paralanguage of computer mediated communication“, u: 80Proceedings of the 18th annual meeting on Association for computatonal linguistics. ACL.

Carter, Ronald (2004.) Language and Creativity: The Art of Common Talk. London; New York: Routledge.

Castells, Manuel (2000.) Informacijsko doba: ekonomija, društvo, kultura. Sv. 1., Uspon umreženog društva. Zagreb: Golden Marketing.

Ceković-Rakonjac, Nevena (2011.),,Različiti pristupi definisanju i opisu diskursnih markera.“ Anali Filološkog fakulteta Univerziteta u Beogradu, 23/2: 133-153.

Chomsky, Noam A. (1965.) Aspects of the Theory of Syntax. Cambridge, Massachusetts: MIT.

Chomsky, Noam A. (1986.) Knowledge of Language: its nature, origin and use. London: Praeger.

Christiansen, Morten H. i Simon Kirby (2003.) „Language evolution: consensus and Controversies.“ TRENDS in Cognitive Sciences, 7 (7): 300-307.

Crystal, David (2006.) Language and the Internet. Cambridge: CUP.

Darwin, Charles R. (2000.) Postanak vrsta: putem prirodnog odabira ili očuvanje povlaštenih 
rasa u borbi za život. Zagreb: Naklada Ljevak.

Dedaić Nelson, Mirjana (2005.) „Ironic denial: Tobože in Croatian political discourse.“ Journal of Pragmatics, 37: 667-683.

Dedaić Nelson, Mirjana i Mirjana Mišković-Luković, ur. (2010.) South Slavic Discourse Particles. Amsterdam; Philadelphia: John Benjamins Publishing Company.

Degand, Lisbeth i Jacqueline Evers-Vermeul (2015.) „Grammaticalization or pragmaticalization of discourse markers? More thatn terminological issue.“ Journal of Historical Pragmatics, 16:1, 59-85.

Detges, Ulrich i Richard Wlatereit (2011.) „Turn-taking as a trigger of language change.“ U: Dessi Schmid et alli (ur.), Rahmen des Sprechens. Beiträge zu Valenztheorie, Varietätenlinguistik, Kognitiven und Historischen Semantik. Tubingen, Narr, 175-190.

Diewald, Gabrielle (2011.) „Pragmaticalization (defined) as grammaticalization of discourse functions.“ Linguistics, 49-2: 365-390.

Dolić, Belkisa (2016.) Diskursne oznake u funkcionalnim stilovima bosanskoga jezika. (Doktorski rad). Zagreb: Filozofski fakultet.

Dunbar, Robin (1996.) Groomig, Gossip, and the Evolution of Language. Cambridge, Massachusetts: Harvard University Press.

Džanko, Minka (2010.) Modalne partikule eben, halt $i$ wohl u njemačkom i njihovi prijevodni ekvivalenti u bosanskom/hrvatskom/srpskom jeziku. Sarajevo: Bosansko filološko društvo.

Ephratt, Michal (2008.) „,The functions of silence“. Journal of Pragmatics, 40, 1909-1938.

Ephratt, Michal (2011.) „Linguistic, paralinguistic and extralinguistic speech and silence“. Journal of Pragmatics, 43, 2286-2307.

Ephratt, Michal (2012.) „We try harder - Silence and Grice's cooperative principle, maxims 
and implicatures“. Language and Communication, 32, 62-79.

Fehr, Ernst i Joseph Henrich (2003.) „Is Strong Reciprocity a Maladaptation? On the Evolutionary Foundation of Human Altruism. CESIFO Working Papers, 859.

Fibras, Jan (1992.) Functional Sentence Perspective in Written and Spoken Communication. Cambridge: Cambridge University Press.

Fischer, Kerstin (2006.) Approaches to discourse particles. Amsterdam: Elsevier.

Frank-Job, Barbara (2006.) „A Dynamic-Interactional Approach to Discourse Markers“. U: Kerstin Fisher (ur.), Approaches to Discourse particles, 395-413. Amsterdam: Elsevier.

Fraser, Bruce (1990.) „An approach to discourse markers“. Journal of Pragmatics, 14 (3), 383-395.

Fraser, Bruce (1996.) „Pragmatic markers“. Pragmatics, 6, 167-190.

Fraser, Bruce (1999.) „What are discourse markers?“. Journal of Pragmatics, 31: 931-952. Boston: Elsevier Science B.V.

Fraser. Bruce i Monica Malamud-Makowski (1996.) „English and Spanish contrastive discourse markers“. Language Sciences, 18 (3/4), 863-881.

Fuchs, Thomas (2016.) „The embodied developement of language.“ U: Gregor Etzmühler i Christian Tewes (ur.), Embodiment in Evolution and Culture. Tübingen: Mohr Siebeck 107-128.

Fung, Loretta i Ronald Carter (2007.) „Discourse Markers and Spoken English: Native and Learner use in Pedagogical Settings“. Applied Linguistics. 28(3), 410-439.

Gabriel, Roy M. (1985.) „Assessing computer literacy: A validated instrument and an empirical results. AEDS Journal, 18 (3), 153-425. 
Garfinkel, Harold (2003.) Studies in Ethnomethodology. Cambridge: Polity Press; Oxford: Blackwell Publishing Company.

Giomi, Riccardo (2020.) Shifting structures, contexts and meanings: A Functional Discourse Grammar account of grammaticalization (Doktorski rad). Lisabon: Universidade de Lisboa, Faculdade de Letras.

Glovacki-Bernardi, Zrinjka (1990.) O tekstu. Zagreb: Školska knjiga.

Goffman, Erving (1967.) Interactional Ritual: Essays on Face-to-Face Behaviour. New York: Anchor Books: Doubleday \& Company, cop.

Grice, Herbert P. (1980.) Logika i razgovor. U: Aleksandar Pavković (ur.) Svest $i$ saznanje: ogledi iz savremene analitičke filozofije. Beograd: Nolit.

Gurak, Laura J. (2001.) Cyberliteracy: Navigating the Internet with Awareness, Yale: YUP.

Halliday, Michael A.K. i Ruqaiya Hasan (1976.) Cohesion in English, Edinburgh Gate, Harrow, UK: Longman, Pearson Education Ltd.

Hassan, Norizah i Azirah Hashim (2009.) „Electronic English in Malaysia: features and language in use.“ English Today, 25 (4), 39-46, Cambridge University Press.

Hansen, Maj-Britt Mosegaard i Corinne Rossari (2005.) „The evolution of pragmatic markers.“ Journal of Historical Pragmatics, 6 (2): 177-187.

Heffer, Hrvoja (1999.) „Poštapalice kao govorni signali.“ U: Badurina et al. (ur.), Teorija $i$ mogućnosti primijenjene pragmalingvistike, Zbornik HDPL-a. Zagreb; Rijeka, 293-300.

Heine, Bernd (2013.) „On discourse markers: grammaticalization, pragmaticalization or something else?“‘. Linguistics, 51 (6): 1205-1247. De Gruyter Mouton.

Hengeveld, Kees and Lachlan MacKenzie (2008.) Functional Discourse Grammar: A Typologically-based Theory of Language Structure. Oxford Scholarship Online. 
Herring, Susan (1999.) „Interactional Coherence in CMC“. Journal of Computer-mediated Communcation. URL: http://jcmc.indiana.edu/vol4/issue4/herring.html (10.10.2015.)

Herring, Susan (2001.) „Computer-mediated Discourse“. U: Deborah Schiffrin, Deborah Tannen i Heidi E. Hamilton (ur.), Handbook of discourse analysis. Oxford: Blacwell.

Herring, Susan (2012.) „Grammar and Electronic Communication.“ U: Carol A. Chapelle (ur.), Encyclopedia of applied linguistics. Oxford: Blacwell \& Wiley Publishing.

Herring, Susan (2013.) „Relevance in Computer-mediated Communication“. U: D. Stein, \& T. Virtanen (Ur.), Handbook of pragmatics of computer-mediated communication, Berlin: Mouton de Gruyter, 245-268.

Hopper, Paul J. i Elizabeth Closs Traugott (2003.) Grammaticalization, 2nd edition. Cambridge: Cambridge University Press.

Hrvatska jezična riznica. Institut za Hrvatski jezik i jezikoslovlje. Dostupno na URL: http://riznica.ihjj.hr/index.hr.html (13.04. 2020.)

Hrvatski mrežni korpus ( $h r W a c)$. Dostupno na URL: http://nlp.ffzg.hr/resources/corpora/hrwac/ (7.07.2020.)

HR4EU. Dostupno na URL: https://www.hr4eu.hr (13.04.2020.)

Hymes, Dell (1972.) „On Communicative Competence.“ U: Pride, J. B., \& Holmes, J. (Ur.), Sociolinguistics, 269-293. Baltimore, USA: Penguin Education, Penguin Books Ltd.

Hymes, Dell (2006.) „Model of Interaction of Language and Social Life.“ U: Bratt Paulston, Christina i Richard Tucker (ur.), Sociolinguistics: The Essential Readings, London: Blackwell. 
Jackendoff, Ray i Stephen Pinker (2005.) „The Nature of the Language Faculty and its Implications for the Evolution of Language (Reply to Fitch, Hauser \& Chomsky)“. Cognition 97: 211-255.

Jakobson, Roman J. (1966.) Lingvistika i poetika. Beograd: Nolit, str. 285-324.

Jaworski, Adam (1993.) The Power of Silence: Social and Pragmatic Perspectives.“ Newbury Park; London, Delhi: Sage Publications.

Jucker, Andreas H. i Yael Ziv (ur.) (1998.) Discourse markers. Description and Theory. Amsterdam; Philladelphia: John Benjamins Publishing.

Jucker, Andreas H. (2017.) „Pragmatics and Language Change: Historical Pragmatics“. U: Yan Huang (ed.), The Oxford Handbook of Pragmatics, Oxord: Oxford University Press, $550-566$.

Karavdić, Zenaida (2011.) „Poštapalice i uzrečice u bosanskom, crnogorskom, hrvatskom i srpskom jeziku.“ U: Tatjana Bečanović et alli (ur.), Međunarodni naučni skup: Njegoševi dani 3: zbornik radova. Nikšić: Filozofski fakultet.

Kay, Robin H. (1992.) „The Computer Literacy Potpourri: A Review of the Literature, or McLuhan Revisited“. Researchgate.net. URL:

https://www.researchgate.net/publication/236123870_The_computer_literacy_potpourri_A_re view_of_the_literature_or_McCluhan_revisited (20.11.2018.)

Kendon, Adam (1995.) „Gestures as illocutionary and discourse structure markers in Southern Italian conversation.“ Journal of Pragmatics, 23(3): 247-279.

Knas, Agnieszka (2009.) „Read my Voice: Expressing Silence and Sound in SMS“. Networking Knowledge: Journal of the MeCCSA Postgraduate Network, 2(1): 1-18.

Končarević, Ksenija (2007.) „Prilog proučavanju metastrukture liturgijskog diskursa - 
načela organizacije i diskursni markeri“. Stil, 6: 179-190.

Koops, Christian i Arne Lohmann (2015.) „A quantitative approach to the grammaticalization of discourse markers: Evidence from their sequencing behaviour." International Journal of Linguistics, 20 (2): 232-259.

Kurzon, Dennis (1998.) Discourse of Silence. Amsterdam; Philadelphia: John Benjamins.

Labov, William i David Fanshel (1977.) Therapeutic Discourse: Psychotherapy as Conversation. New York: Academic Press.

Lakoff, George and Mark Johnson (1980.) Metaphors We live by. Chicago; London: University of Chicago Press.

Leech, Geoffrey (1983.) Principles of Pragmatics. London; New York: Longman.

Lehmann, Christian (1995.) Thoughts on Grammaticalization. München: LINCOM, Europa.

Lenk, Uta (1998.) Marking discourse coherence. Function of discourse markers in spoken English. Tübingen: Narr.

Levinson, Stephen C. (1983.) Pragmatics. Cambridge: CUP.

Liddicoat, Anthony J. (2007.) An Introduction to Conversation Analysis. London: Continuum, cop.

Lyons, John (1972.) „Human language“. U: R.A. Hinde (ur.): Nonverbal Communication. Cabridge: CUP, 49-85.

Low, Ee Ling and David Deterding (2003.) „A corpus-based description of particles in spoken Singapore English“. U: D. Deterding, E.L. Low and A. Brown (ur.), English in Singapore: Research on grammar, Singapore: McGraw Hill, 58-66.

Maly, Ico and Jan Blommaert (2019.) „Digital Ethnographic Linguistic Landscape Analysis 
(ELLA 2.0).“ 16th Annual IMISCOE conference, June 26-28, 2019, University of Malmö, Sweden.

Marcela, Claudia i Chapetón Castro (2009.) „The Use and Funcions of Discourse Markers in EFL Classroom Interaction“. Profile, 11, 57-77.

Maschler, Yael i Deborah Schiffrin (2015.) „Discourse markers: Language, meaning and context.“ U D. Tannen, H.E. Hamilton i D. Schiffrin (ur.): The Handbook of Discourse Analysis, second edition, Chichester, UK: Johm Wiley \& Sons, 189-221.

McLuhan, Marshall (2008.) Razumijevanje medija: mediji kao čovjekovi produžeci. Zagreb: Golden marketing - Tehnička knjiga.

McNeill, David (2005.) Gesture and Thought. Chicago, IL: University of Chicago Press.

Merleau-Ponty, Maurice (2004.) Phenomenology of Perception. New York; London: Routledge.

Mišić-Ilić, Biljana i Vesna Lopčić (2011.) „Pragmatički anglicizmi u srpskom jeziku.“ Zbornik Matice srpske za filologiju i lingvistiku, 54/1: 261-273.

Mladenović, Dragan (2009.) „Zašto sajber a ne kiber?“ Dostupno na URL: http://www.audioifotoarhiv.com/gosti\%20sajta/DraganMladenovic5.html (05.05.2019.)

Murillo, Silvia (2004.) „A relevance reassessment of reformulation markers.“ Journal of Pragmatics, 36, 2059-2068.

Nigoević, Magdalena (2010.) Diskursne oznake u hrvatskom i talijanskom jeziku. Kontrastivna analiza (Doktorski rad). Zadar: Filozofski fakultet Sveučilišta u Zadru.

Nöth, Winfried (2001.) „Semiotic functions of iconicity in language and literature.“ U: Olga Fischer i Max Nänny (ur.): The Motivated Sign. Amsterdam: John Benjamins Publishing.

Palacio, May A. i Leah Gustilo (2016.) „A Pragmatic Analysis of Discourse Particles in 
Filipino Computer-mediated Communication“. GEMA Online ${ }^{\circledR}$ Journal of Language Studies, 16 (3), 1-19.

Panić, Natalija M. (2012.) Prozodijski markeri citiranog govora u razgovornom jeziku (Doktorski rad). Beograd: Filološki fakultet Univerziteta u Beogradu.

Park, Jung-ran (2007.) „Solidarity and Rapport in Social Interaction“. U: S. Kelsey i K. St. Amant (ur.), Handbook of Research on Computer-mediated Communication, New York: Information Science Reference, 934-946.

Pinker, Stephen i Paul Bloom (1990.) „Natural Language and Natural Selection.“ Bihevioural and Brain Sciences, 13: 707-784.

Pintarić, Neda (2002.) Pragmemi u komunikaciji. Zagreb: Zavod za lingvistiku FFZG.

Popović, Ljudmila (2009.) „Leksičke inovacije u elektronskom diskursu hrvatskog i srpskog jezika“. U: Branko Tošović (ur.), The Unterschieden zwischen dem Bosnischen/ Bosniakischen, Kroatischen und Serbischen. Lexik - Wortbildung - Phraseologie, Berlin: LIT Verlag, 183-204.

Portolés, José (1998.) Marcadores del discurso. Barcelona: Ariel.

Poyatos, Fernando (2002.) Nonverbal Communication Across Disciplines. Amsterdam; Philadelphia: John Benjamins Publishing.

Redeker, Gisela (1991.) „Linguistic markers of discourse structure“. Linguistics 29, 11391172 .

Reid, Elizabeth M. (1994.) Cultural Formations in Text-Based Virtual Realities. Magistarski rad (MA), Sveučilište u Melbourneu: Australija.

Ritzer, George (1997.) Suvremena sociologijska teorija. Zagreb: Nakladni zavod Globus.

Ruthorf, Horst (2007.) „Principles of Corporeal Pragmatics.“ The Public Journal of Semiotics 
1(2): $12-30$.

Savignon, Sandra J. (1972.) Communicative Competence: An Experiment in ForeignLanguage Teaching. Philadelphia: The Centre for Curriculum Development, Inc.

Scahndorf, Michael (2014.) „Mediated gesture: Paralinguistic communication and phatic text." Convergence: The International Journal of Research into New Media Technologies, 19(3): 319-344.

Schiffrin, Deborah (1984.) Approaches to Discourse. Oxford; Cambridge: Blackwell.

Schiffrin, Deborah (1987.) Disccourse Markers. Cambridge: CUP.

Schourup, Lawrence (1999.) „Discourse markers“. Lingua 107, 227-265. Elsevier Science B.V.

Searle, John (1980.) Speech Acts: An Essay in the Philosophy of Language. Cambridge: CUP.

Sesar, Dubravka (1992.) „O mogućnostima kategorizacije partikula u hrvatskom jezičnom standardu." Suvremena lingvistika, 34: 251-262.

Sesar, Dubravka (2001.) „Modalni modeli u hrvatskom i drugim slavenskim jezicima.“ Suvremena lingvistika, 1-2/51-52: 203-218.

Silić, Josip (1984.) Od rečenice do teksta. Teoretsko-metodološke pretpostavke nadrečeničnog jedinstva. Zagreb: SNL.

Silverman, David (2003.) „Analysing Talk and Text“. U: Norman K. Denzin and Yvonna S. Lincoln (eds.), Collecting and Interpreting Qualitative Material. Thousand Oaks; London; New Delhi: Sage Publications.

Sperber, Dan i Deirdre Wilson (1986./1995.) Relevance: Communication and Cognition. Oxford: Blackwell. 
Stepanov, Strahinja (2010.) „O konektorima u hrvatskim i srpskim novinskim komentarima.“ U: Branko Tošović (ur.), The Unterschieden zwischen dem Bosnischen/ Bosniakischen, Kroatischen und Serbischen. Sammelband 3. Berlin: LIT Verlag, 347-374.

Stubbs, Michael (1983.) Discourse Analysis: The Sociolinguistic Analysis of Natural Language. Chicago: University of Chicago Press.

Tadić, Marko (1998.) „Raspon, opseg i sastav korpusa hrvatskoga suvremenog jezika.” Filologija, 30-31, 337-347.

Tannen, Deborah i Muriel Saville-Troike (ur.) (1985./1995.) Perspectives on Silence. New Jersey: Ablex Publishing Corp.

Tay, Li Chia, Mei Yuit Chan, Ngee Thai Yap i Bee Eng Wong (2012.) „Use of discourse particles in Facebook wall posts among Chinese Malaysian youth“".

The Proceedings of the 7th Malaysia International Conference on Languages, Literatures, and Cultures: Universiti Putra Malaysia. URL:

https://cmyfbmk.files.wordpress.com/2012/11/use-of-discourse-particles-in-facebook-4.pdf (30.09.2019.)

Taylor, David S. (1988.) „The meaning and use of the term competence in linguistics and applied linguistics“. Applied Linguistics, 9, 148-169.

Tekavčić, Pavao (1982.) „O prilozima i 'prilozima'. Sintakto-semantičke, pragmalingvističke i kontrastivne bilješke.“ Strani jezici, 1/2: 3-12.

Traugott, Elisabeth Closs (1995.), ,The role of the development od discourse markers in a theory of grammaticalization. 12th International Conference on Historical Linguistics, University of Manchester, Manchester, England, 1-23.

Traugott, Elisabeth Closs i Richard B. Dasher (2005.) Regularity in Semantic Change. Cambridge: Cambridge University Press.

Traugott, Elisabeth Closs (2010.) „Revistinig subjecitification and intersubjecitification.“ 
U: Kristin Davidse, Lieven Vandelanotte i Hubert Cuyckens (ur.), Subjectification, Intersubjectification and Grammaticalization. Berlin: Mouton de Gruyter, 29-70.

Urban Dictionary. Dostupno na URL: https://www.urbandictionary.com (14.07.2020.)

Velčić, Mirna (1987.) Uvod u lingvistiku teksta. Zagreb: Školska knjiga.

Vrljić, Stojan (2007.) „Poštapalice u hrvatskom jeziku.“ Jezik, 54: 60-64.

Vuković, Milica (2010.) „Polarizacija u političkom diskursu: upotreba zamjenica u televizijskim intervjuima.“ Folia Linguistica et Litteraria, 1 i 2: 399-411.

Waltereit, Richard (2002.) „Grammaticalization vs. reanalysis: a semantic-pragmatic account of functional change in grammar.“ Zeitschrift für Sprachwissenschaft, 21 (2): 151-195.

Waltereit, Richard (2006.) „The Rise of Discourse Marker sin Italian: a specific type of language change.“ Approaches to discourse particles, 1: 61-76.

Walther, Joseph B. (1996.) „Computer-mediated communication: Impersonal, interpersonal, and hyperpersonal interaction." Communication Research, 23: 3-43.

Weiss, Gail (1999.) Body Images: Embodiment as Intercorporeality. New York: Routledge.

Wharton, Tim (2009.) Pragmatics and Non-Verbal Communication. Cambridge: Cambridge University Press.

Widdowson, Henry G. (1983.) Learning Purpose and Language Use. Oxford: Oxford University Press.

Wildgen, Wolfgang (2007.) „Evolutionary pragmatics.“ U: Handbook of Pragmatics Online, John Benjamins Publishing Company, Volume 11, str. 1-22. Dostupno na URL: https://benjamins.com/online/hop/articles/evo1 (14.04.2020.)

Young, Garry and Monica T. Whitty (2010.) „In Search of the Cartesian Self: An 
Examination od Disembodiment witih 21st-Century Communication." Theory \& Psychology, 20 (2): 209-229.

Yus, Francisco (2011.) Cyberpragmatics. Internet-mediated communication in context. Amsterdam; Philadelphia: John Benjamins Publishing.

Yus, Francisco (2018.) „The interface between pragmatics and internet-mediated communication: Applications, extensions and adjustments“. Researchgate, URL:

https://www.researchgate.net/publication/327215174_The_interface_between_pragmatics_an

d_internet-mediated_communication_Applications_extensions_and_adjustments(15.08.2019.)

Zovko, Irena (1999.) „Uporaba riječi 'ono' u govorenom jeziku.“ U: Teorija i mogućnosti primjene pragmalingvistike: zbornik. Zagreb; Rijeka: HDPL, 859-862.

Zwicky, Arnold M. (1985.) „Clitics and Particles“. Language, 61 (2), 283-305. 


\section{PRILOZI}

\section{PRILOG 1}

Izvadak iz transkripta razgovora vođenog s pomoću aplikacije Whatsapp. Diskursne su oznake zaokružene crvenom bojom.

DhatsApp razgovor s txt - Notepad

File Edit Format View Help

p9. 11. 2017. 11:06 - Poruke poslane na ovaj razgovor i pozivi sad su osigurani end-to-end metodor 09. 11. 2017. $11: 06$

09. 11. 2017. 11:07 -

09. 11. 2017. 11:07 -

09. 11. 2017. 11:07 -

09. 11. 2017. 11:09

09. 11. 2017. 11:09

09. 11. 2017. 11:10

09. 11. 2017. 11:10 -

09. 11. 2017. 11:10 -

09. 11. 2017. 11:10 -

09. 11. 2017. 11:10 Kaj ima? Si ziva?

09. 11. 2017. 11:11 - J : Aha, tajming nam nije jača strana (2)

\section{PRILOG 2}

Modificiranje ilokucijske snage govornih činova (direktiva) s pomoću diskursnih oznaka na početku i kraju iskaza.

12. 11. 2017. 14:57 - J

12. 11. 2017. $15: 04-$

12. 11. 2017. 15:05 -

12. 11. 2017. 15:07 -

12. 11. 2017. 15:07

12. 11. 2017. $15: 19$

12. 11. 2017. $15: 26-$

Je 1 stiglo??

Pa evo cekam da mi stave zimske gume!

[ Kai ti? Zabrijala sam da me izbjegavas!

(A) Karlovcu si, ne izbjevam te, imao sam posla hrpu

:(Ma) tu sam do popodne/predvecer, isla sam to zbavit

: Pa super

Mogao bi se javit makar za kav $\ldots$

Kjznm

RUuis!3 (2)

Rera evo javio sam se

12. 11. 2017. 15:29 -

Mozes dodat pored imena u zagradu kraticu (ACME)

\section{Pliz}

Dodaj rraticu

8

: No? Jesi dobio??

: Idem chekirat, imo sam posla

Ajdocekira), stavi ACME i avi plz 


\section{PRILOG 3}

Diskursne oznake i mehanizmi uređivanja razgovora u CA okviru.

WhatsApp razgovor s txt - Notepad

$-\square \quad x$

File Edit Format View Help

10. 11. 2017, 10:27 -

10. 11. 2017, $10: 28-$

10. 11. 2017. $10: 28-$

10. 11. 2017. $10: 32-$

10. 11. 2017, $10: 32-$

10. 11. 2017. $10: 33-$

01, New day, New numbers to be quested! od joze mi treba broj, imas mozda?

: 0 boze, vec sam mislila da saljes automatizirane poruke! Ono hello there, i just joined whatsapp (a)

cek sekundu

E to je bilo u starom mobu bit ce, ali javila sam mu se na fejs za broj, pa ti javim kad odgovori

Osjecam se ko sekretarica!!

: Thanx, zvao bi ga da vrti mjuzu 17og, htio bi napraviti pokret odmora

\section{PRILOG 4}

Korištenje imitativa u funkciji diskursne oznake kojom se iskazuje emotivno stanje/stav prema situaciji i zatvara se iskaz.

\begin{tabular}{|c|c|}
\hline WhatsApp razgovor s & txt - Notepad \\
\hline File Edit Format View Help & \\
\hline $\begin{array}{l}\text { 13. } 06.2017 .22: 56-\mathrm{J} \\
\text { 14. } 06.2017 .08: 01-\mathrm{J}\end{array}$ & $\begin{array}{l}\text { : Hjaooo tri sata za tri palete } i \text { to na pol potrgane. Kmeee } \\
\text { Nis, bude bila osb il tak nes, mozemo danas popodne u nek1 od tih ducana }\end{array}$ \\
\hline
\end{tabular}

\section{PRILOG 5}

Primjer diskursnih oznaka u vidu ograda, tj. razdvajanja različitih iskaza s pomoću nepopunjenih pauza/šutnje u vidu trotočja.

Pa ne znam, sad je bas upekl@ @ije za ic nigdje...) cemo kasnije popodne...udem oprat sudje i ususavat malo sad ok, mozemo kasnije, $5 / 6$ ?

\section{PRILOG 6}

Diskursna oznaka u vidu popunjene pauze (engl. filler).

10. 06. 2018. 10:49 - J $\square$ : Ja dodjem nekad sutra predvecer! oces me docekat s vecerom? (-):-0 10. 06. 2018. 10:49 : Hmmm, ak ne odem u Milano 


\section{PRILOG 7}

Konektor ono upotrebljen radi kontekstualiziranja prenesenog sadržaja, uvođenja opisa situacije s pomoću deiktičnog izraza. U ovom slučaju zamjenica ono u službi je konektora nakon kojeg dolazi pojašnjenje, kao u slučaju klasičnih veznika poput dakle ili glagola značiti (tj. znači) u funkciji diskursne oznake. Ovdje bi stoga bila riječ o naglašavanju referencijalne funckije.

23. 11. 2019. 17:02

23. 11. 2019. 17:03 -

23. 11. 2019. 17:03 -

23. 11. 2019. 17:03 -

23. 11. 2019. 17:04 -

23. 11. 2019, 17:04 -
Jesu makar dobri ti sendviči? (-)

: Ne!! Ahahahah al svuda po gradu, ono, klopa i cuga, ko neke birtije,i ili sendvič ili tortill : Pa ti biraj

: Ahahahah

I njima je to bomba

Uooce nemaju potrebu za necim drugim

\section{PRILOG 8}

Primjer konektora dakle upotrijebljen je sa svrhom pojašnjenja prethodno poslanog medijskog sadržaja u vidu fotografija i tipičan je za multimodalnu komunikaciju. Iz primjera je također vidljivo miješanje kodova, posebice utjecaj engleskog jezika koji dominira sferom cyber-diskursa.

03. 02. 2019, $20: 28-$

03. $02.2019,20: 28-$

03. $02.2019,20: 28-$

03. 02. 2019. 20:28

03. 02. 2019, 20:30 -

03. 02. 2019. $20: 30$

I

〈Medijski zapis izostavljen〉

〈Medijski zapis izostavljen〉

〈Medijski zapis izostavljen〉

〈Medijski zapis izostavljen〉

Dakle: princess grip, open genie, vertical split (sa ukrizenim rukama), russian layback brid Nisu bas neke perspektive, neki elementi bi bolje izgledali da su s kontra strane slikani

\section{PRILOG 9}

Primjer konektora $a$ ubačenog na početak iskaza s ciljem naglašavanja suprotnosti u odnosu na sadržaj prethodnog diskursa, ali i s ciljem nadovezivanja na isti.

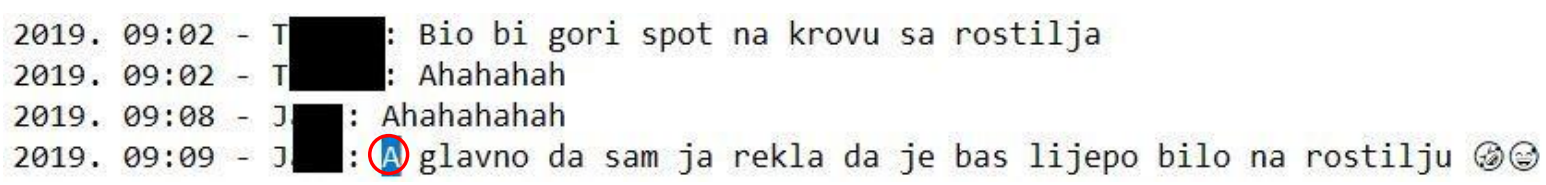


Primjer popunjivača $h m$ ubačenog u iskaz s ciljem dobivanja na vremenu za razmišljanje. Ovom se diskursnom oznakom također izražava stav (obično sumnja) te može biti u funkciji signalizacije držanja reda u govorenju, pritom dajući do znanja našem sugovorniku da još razmišljamo o temi.

15. $07.2018 .08: 45-$

15. $07.2018 .08: 46$

: Ima Filipi jeep, i prikoliča

Ak krene padat, nis ni od prikolice..(hm, sretno s tim svim

\section{PRILOG 11}

Na početku ovog primjera imamo interaktivnu oznaku hej, u službi otvaranja razgovora, u obliku formulaičnog izraza (pozdrava) sa svrhom ostvarenja kontakta (fatička funkcija). Nakon toga slijedi konektor nego koji strukturira razgovor pomičući fokus na temu od interesa. Glagol daj govorni je čin (direktiv) koji usmjerava iskaz na sugovornika (konativna funkcija), jednako tako to je slučaj s ček. Čestica ma spada pod modalne oznake (modifikatore), čiji je osnovni cilj prenijeti govornikov stav o sadržaju njegova/njezina vlastita iskaza. Time se ističe ekspresivna/emotivna komunikacijska funkcija jezika i usmjerava sugovornikovo zaključivanje o značenju iskaza.

03. 01. 2018. 12:55 -

03. 01. 2018. 12:56 -

03. 01. 2018. 13:13

03. 01. 2018. 13:14 -

03. 01. 2018. $13: 14$

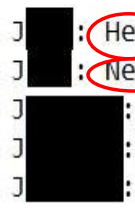

Hej. Sori kj gnjavim, uzivaj u sunji

ivego daj) mi posalji koju fotku sanka od doceka (ja nisam nis pofotkala (Ma)nisu nes fotke, cek

〈Medijski zapis izostavljen〉

〈Medijski zapis izostavljen〉

\section{PRILOG 12}

U ovome se primjeru također mogu primijetiti različite vrste diskursnih oznaka. Na samome početku imamo čitav iskaz sastavljen od zaredanih diskursnih oznaka, pri čemu je čestica eto konektor u vidu prostorne deikse koja predstavlja anaforu (tiče se prethodnog odsječka diskursa). Svašta se ovdje također ponaša kao diskursna oznaka, a ne kao neodređena zamjenica i zapravo nam prenosi govornikov stav prema prethodnom sadržaju, te time postaje modifikator. Naposljetku, glagol kužiš (ponekad skraćeno $k u^{\prime} i s ̌$ ) obnaša funkciju interaktiva, ističući fatički element komunikacije. Njime se od sugovornika zahtijeva povratna informacija, provjerava razumijevanje i održava informacijski tijek.

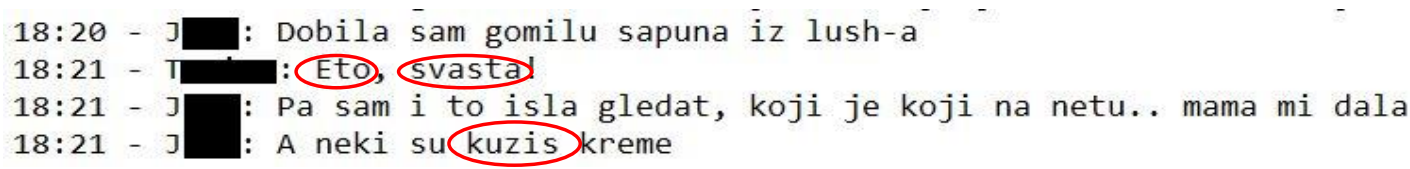




\section{PRILOG 13}

Šutnja u formi neverbalne geste (emoji kojim se prikazuje gesta pokrivanja lica dlanom, zatvarajući i prekrivajući oči, sa značenjem razočarenja, srama, frustracije ili sarkazma; na engleskom jeziku to pokriva izraz facepalm, ponekad korišten kao kratica $f p$ umjesto samog emojija).
15. $04.2020 .16: 59-$
15. $04.2020 .17: 00-$
15. 04. 2020. 17:00 - Jana: Aj misli na nkj pametnije, plz
: kriza nek traje i banda Ce kupovat

\section{PRILOG 14}

Šutnja u proceduralnoj funkciji (upotreba trotočja s ciljem strukturiranja diskursa). Može se interpretirati kao konativna (u dijalozima) i kao metajezična. Ova bi se trotočja mogla interpetirati kao ograde (engl. hedges) i svrstati se u podvrstu konektora i popunjivača diskursa.

15. 04. 2020. 16:41 - Jana: Pa da, veselis se tome «s
15. 04. 2020. 16:41 - Tomica: a cekat cu bar jos 5 tjedana! tak da...
15. 04. 2020. 16:41 - Jana: Znaci koristit ces na jesen ry
15. 04. 2020. 16:42 - Jana: Tj zimu.. ak ovo sve splasne

\section{PRILOG 15}

Šutnja u ekspresivnoj i konativnoj funkciji (upitnici kao znak zbunjenosti, osupnutosti, čuđenja i/ili traženja objašnjenja).

30. 04. 2020. 08:45 - Jana: Upravo sam razgovarala sa svojim macom (2) zove se Siri, i odgovara na moja pitanja zenskim glasom, brutish english

30. 04. 2020. 08:46 - Jana: 0sjecam se ko u crvenom patuljku, da pricam s holly

30. 04. 2020. 08:47 - Tomica: ???

30. 04. 2020. 08:47 - Jana: Ima voice recognition i odgovara ti. 


\section{ŽIVOTOPIS}

Jana Jurčević diplomirala je 2011. godine na Filozofskom fakultetu u Zagrebu, na Odsjeku za lingvistiku i Odsjeku za sociologiju.

U diplomskom radu iz područja lingvistike obradila je temu komunikacije posredstvom računala, pod naslovom Svakodnevna i neformalna komunikacija u računalno posredovanom diskursu: Instant Messaging. Uz pružen teorijski okvir, u radu je izvršena konverzacijska analiza (Liddicoat, Garfinkel, Goffman) i pragmalingvistička analiza (Grice, Leech, Austin, Searle) prikupljenog korpusa razgovora nastalog razmjenom instant-poruka, s osnovnim ciljem prikazivanja prilagodbe hrvatskog jezika internetu kao novom komunikacijskom mediju.

$\mathrm{Na}$ Odsjeku za sociologiju diplomirala je temom Izgradnja virtualnog identiteta $i$ upravljanje impresijama: Upotreba fotografija na društvenim mrežama.

Od rujna 2012. godine zaposlena je na Filozofskom fakultetu u Zagrebu kao asistent na Odsjeku za lingvistiku (Katedra za primijenjenu lingvistiku), gdje sudjeluje pri izvođenju kolegija „Jezik u javnoj i interpersonalnoj komunikaciji“, „Lingvistika i njezini dijalekti““, „Primijenjena lingvistika“, „Analiza diskursa“ te (periodički) „Semantika razumijevanja“.

Akademske godine 2012./2013. upisala je Poslijediplomski doktorski studij lingvistike na Filozofskom fakultetu u Zagrebu.

Uža joj područja interesa obuhvaćaju domenu pragmalingvistike, sociolingvistike, (kritičke) analize dikskursa, cyber-komunikacije, filozofije jezika, semiotike digitalnih medija i teorija jezične evolucije. 


\section{Popis radova i aktivnih sudjelovanja na znanstvenim skupovima:}

1. Jurčević, Jana.

Beyond Traditional Standardization: Language Policing in a Digital Era // SECOND INTERNATIONAL CONFERENCE ON SOCIOLINGUISTICS: Insights from Superdiversity, Complexity and Multimodality, ELTE, Budimpešta, Mađarska, 2018 (Znanstveni skupovi i radionice, usmeno izlaganje, međunarodna recenzija, neobjavljeni rad, znanstveni).

\section{Jurčević, Jana}

Sound symbolism of contemporary communication: imitative expressions in computermediated discourse // Second International Workshop LMAC, Saint Petersburg, Rusija, 2017 (Znanstveni skupovi i radionice, usmeno izlaganje, međunarodna recenzija, objavljeno poglavlje u knjizi Language, Music and Computing, DOI: 10.1007/978-3-030-05594-3_8 ).

\section{Jurčević, Jana}

Discourse Markers in Computer-mediated Communication: The Case of Abbreviations // Intercultural pragmatics and communication conference, Split, Hrvatska, 2016 (Znanstveni skupovi i radionice, usmeno izlaganje, međunarodna recenzija, neobjavljeni rad, znanstveni).

4. Bertoša, Mislava; Miškulin-Saletović, Lucija; Jurčević, Jana

The Concept of Water in Advertisements of Body Care Products // Zadarski filološki dani 6, Zadar, Hrvatska, 2015 (Znanstveni skupovi i radionice, usmeno izlaganje).

5. Bertoša, Mislava; Miškulin Saletović, Lucija; Jurčević, Jana

Personal Names in Multimodal Advertising Texts // Magyar Tudomány Ünnepe 2014 
alkalmából, Baja, Mađarska, 2014 (Znanstveni skupovi i radionice, usmeno izlaganje, međunardna recenzija, neobjavljeni rad, znanstveni).

6. Jurčević, Jana; Erdeljac, Vlasta

Položaj i budućnost hrvatskog jezika u Europskoj uniji: jezične debate u javnom diskursu // Standardni jezici i sociolekti u 21. stoljeću, Dubrovnik, Hrvatska, 2011 (Znanstveni skupovi i radionice, usmeno izlaganje, neobjavljeni rad, znanstveni). 